\title{
IN THE MINDS OF MEN*: A THEORY OF COMPLIANCE \\ WITH THE LAWS OF WAR
}

\section{William Bradford}

\section{Introduction}

Does international law matter, or is it but a "fairy ship upon a fairy sea: a beautiful construct of the legal imagination floating upon a sea of false assumptions[?]"2 For many scholars the international system has matured since the end of the Cold War and international law, no longer a primitive legal system constantly obligated to prove its existence and utterly dependent upon politics for its enforcement, ${ }^{3}$ now significantly constrains and shapes the behavior of states. ${ }^{4}$ Some go so far as to posit that the diffusion of the international rule of law is so advanced that the demise of state sovereignty as traditionally conceived is nigh. ${ }^{5}$ For these observers, the famous aphorism - that "it is probably the case that almost all nations observe almost all principles of international law and almost all of their obligations almost all of the time" - waxes ever more descriptive of the political universe with each successive wave of legalization, for on those increasingly rare instances when states violate international law they are compelled to justify their conduct in the face of vigorous denunciations and recriminations. ${ }^{7}$ Convinced that history has released them from the tiresome obligation to prove that international law is really law, ${ }^{8}$ legalization theorists conclude that solutions to contemporary transnational problems are to be found in more, or at least better-tempered, legal regulation, ${ }^{9}$ for if international law does not per se dictate state behavior, compliance ${ }^{10}$ is the rule and not the exception.

\footnotetext{
* See UNITED NATIONS EDUCATIONAL, SCIENTIFIC AND CULTURAL ORGANIZATION, at Preamble ("Since wars begin in the minds of men, it is in the minds of men that the defences of peace must be constructed."), available at <http://portal.unesco.org/en/ev.php-URL_ID=6206\&URL_DO=DO_TOPIC\&URL_SECTION=201.html>.

${ }^{1}$ Assistant Professor of Law (promotable), Indiana University School of Law, Indianapolis, Indiana. I would like to extend my thanks to Antonia Chayes, Andrew Guzman, Oona Hathaway, Derek Jinks, David Moore, Eric Posner, Steve Ratner, Kal Raustiala, Beth Simmons, and Anne-Marie Slaughter for reading and commenting on earlier drafts.

${ }^{2}$ C.G. WEERAMANTRY, UNIVERSALISING INTERNATIONAL LAW 34 (2004).

${ }^{3}$ See John Setear, An Iterative Perspective on Treaties: A Synthesis of International Relations Theory and International Law, 37 HARV. INTL L.J. 139, 139-40 (characterizing international law thusly a decade ago); cf. DAVID J. BEDERMAN, THE SPIRIT OF INTERNATIONAL LAW 22 (contending that international law now exhibits "many features of 'mature' domestic legal systems[.]").

${ }^{4}$ See, e.g., Andrew T. Guzman, A Compliance-Based Theory of International Law, 90 CAL. L. REV. 1823, 1826 (2002); see also Jonathan Zasloff, Law and the Shaping of American Foreign Policy: The Twenty Years' Crisis, 77 S. CAL. L. REV. 583,583 (2004) ("International law . . . has blossomed over the last decade into a cutting-edge academic discipline.").

${ }^{5}$ See Jose E. Alvarez, Why Nations Behave, 19 MICH. J. INT'L L. 303, 303 (1998) (predicting that increasing international legal regulation portends the "demise" of traditional notions of sovereignty).

${ }^{6}$ LOUIS HENKIN, HOW NATIONS BEHAVE 47 (1968).

${ }^{7}$ See Eric Posner, A Theory of the Laws of War, 70 U. CHI. L. REV. 297, 297 (2003) (noting that even during war states dispute that their actions are illegal or attempt to justify their violations of law as excusable).

${ }^{8}$ See Kal Raustiala \& Anne-Marie Slaughter, International Law, International Relations and Compliance, in HANDBOOK OF INTERNATIONAL RELATIONS (W. Carlsnaes, T. Risse, \& B.A. Simmons eds., 2002), at 540 (noting that for "much of the Cold War, [international legal] scholarship ... was part of the larger project of demonstrating that "international law mattered"'); Hilaire McCoubrey, Natural Law, Religion and the Development of International Law, in Religion and International Law (Mark Janis \& Carolyn Evans eds. 2004) (suggesting the debate over whether international law "is indeed 'law" continues).

${ }^{9}$ See, e.g., Miles Kahler, Conclusion: The Causes and Consequences of Legalization, 54 INT'L ORG. 661, 661 (2000) (describing the conclusion of the school-of-thought labeled "legalization" theory). Some legalization scholars differentiate between additional layers of legal regulation and more effective regulation. See, e.g., Emeka Duruigbo, International Relations, Economics and Compliance with International Law: Harnessing Common Resources to Protect the Environment and Solve Global Problems, 31 CAL. W. INT'L L.J. 177, 177 (2001).

10 "Compliance" refers to adherence to and conformance by relevant actors with the prescriptions and proscriptions of the legal regime established in respect to a particular issue-area. See ORAN R. YOUNG, COMPLIANCE AND PUBLIC AUTHORITY 3 (1979); see also Raustiala \& Slaughter, supra note 8, at 539 (defining "compliance" as "a state of conformity between an actor's behavior and a specified rule[.]").
} 
Skeptics have subjected this argument to post-ontological inquires such as why, and under what conditions, states choose to create and comply with international law. ${ }^{11}$ Empirical observation suggests that noncompliance is common, particularly in issue-areas such as human rights ${ }^{12}$ and ethnic conflicts that challenge state sovereignty, ${ }^{13}$ and states appear to accept legal obligations without intending to honor them. ${ }^{14}$ Some suggest that international legal regimes are little more than aspirational ventures; others wonder whether increased formalization actually inversely correlates with compliance with the normative principles underlying regimes. ${ }^{15}$ For skeptics, if perfect compliance is not necessary to establish the significance of law to international relations, a clear and consistent pattern of compliance is sine qua non, and legalization theorists have abjectly failed to carry their burden of proving that states consistently obey legal rules contrary to their parochial interests. ${ }^{16}$

Whether, and, if so, why states elect to comply with international law are now the most central questions within the international legal academy, and the answers are laden with implications for the role of law in the ordering of international relations. ${ }^{17}$ The former question alone bifurcates the field. Uncertainty as to the meaning of ambiguous treaty terms, along with contestation over the parameters of customary international law, erode consensus as to precisely what rules apply to a given issue-area, ${ }^{18}$ and thus the very process of operationalizing "compliance" requires subjective judgments. Investigators must decide how to interpret partial or unintentional compliance, ${ }^{19}$ and information is not always readily available and reliable. ${ }^{20}$ Moreover, because they are more likely to self-report compliance accurately than authoritarian states, liberal democracies may spuriously appear less compliant than their counterparts. ${ }^{21}$ Finally, certain issue-areas, including armed conflict and weapons development, are more closely

\footnotetext{
${ }^{11}$ A declining number of commentators continues to assert that international law is not really law because it is not enforced by a central coercive authority. See BEDERMAN, supra note 3, at 1 .

${ }^{12}$ See generally Oona Hathaway, Do Human Rights Treaties Make a Difference?, 111 YALE L.J. 1935 (2002); see also Kahler, supra note 9, at 677 (noting that despite a formal legal regime prohibiting torture, many states, including a number of democracies, engage in the practice).

${ }^{13}$ See generally Steven R. Ratner, Does International Law Matter in Preventing Ethnic Conflict?, 32 N.Y.U. J. INT'L L. \& POL. 591 (2000). Some observers query whether certain issue-areas in international relations, such as the use of force, may be unregulable inasmuch as they trench in subject matter considered central to state survival, national security, or other issues of high politics. See, e.g., John Norton Moore, Enhancing Compliance with International Law: A Neglected Remedy, 39 VA. J. INT'L L. 881, 884 (1999) ("[T]he greatest challenge for the future of the rule of law internationally is to enhance rates of compliance, even in areas traditionally considered by the Realists as unregulable by law[.]").

${ }^{14}$ YOUNG, supra note 10, at 1.

${ }^{15}$ See, e.g., Ryan Goodman \& Derek Jinks, Measuring the Effects of Human Rights Treaties, 13 EUR. J. INT'L L. 171, 171 (2002) ("It is a radical critique of international law to suggest that international legal regimes actually worsen the problems they were created to address.").

${ }^{16}$ See generally MAX WEBER, THE THEORY OF SOCIAL AND ECONOMIC ORGANIZATIONS (1947) (contending that the test of compliance is whether legal rules are obeyed irrespective of personal gains or losses incurred in doing so).

${ }^{17}$ Guzman, supra note 4, at 1826 . Nearly all theories accept that the question of compliance is theoretically significant only to the extent that states are capable of complying; without such capacity, the compliance decision is not in fact a choice, although most states are capable of compliance.

${ }^{18}$ See MICHAEL BYERS \& GEORG NOLTE, UNITED STATES HEGEMONY AND THE FOUNDATIONS OF INTERNATIONAL LAW 428-29 (2003) ("The compliance concept is closely related to a positivist understanding of law which assumes a clear divide between legal and illegal behavior ... [and] the difficulty of unequivocally distinguishing a 'legal' action from one that is 'illegal' is made only more difficult by the increasing number of contradictions and conflicts emerging within international law.”); see also Harold K. Jacobson, Conceptual, Methodological and Substantive Issues Entwined in Studying Compliance, $19 \mathrm{MICH}$. J. INT'L L. 569, 570 (noting that analyzing compliance requires a preliminary determination of what obligations are created by complex and ambiguous sources of law).

${ }^{19}$ See Hathaway, supra note 12, at 1964 (reminding that compliance is "not an on-off switch").

${ }^{20}$ Richard L. Williamson, Hard Law, Soft Law, and Non-Law in Multilateral Arms Control Some Compliance Hypotheses, 4 CHI. J. INT'L L. 59, 69 (2003).

${ }^{21}$ Goodman \& Jinks, supra note 15, at 175.
} 
shrouded in secrecy and thus less amenable to investigation. ${ }^{22}$ In subjecting the question of whether states comply with international law to empirical examination, and in redesigning legal regimes to enhance compliance, epistemological problems abound.

Moreover, in regard to the "Why?" question, a skein of theories has been woven over the last decade to explain and predict state compliance, and a number of factors, including, inter alia, a desire to generate reciprocity, an interest in reducing transaction costs, normative commitments, domestic considerations, the degree of domestic incorporation, reputational concerns, and fear of punishment, are purported to be causally linked. ${ }^{23}$ However, as the study of international legal compliance ["ILC"] has matured, intramural divisions have been compounded by a gathering suspicion that many states are prone to accept only those legal obligations that do not significantly impose real constraints ${ }^{24}$ and that the concept "compliance" may thus not be an adequate framework within which to evaluate whether international legal regimes further their normative policy objectives. ${ }^{25}$ A high level of compliance with a given regime may simply reflect the failure to require states to undertake anything more than "modest departures from what they would have done in the absence of an agreement." ${ }^{26}$ Many treaties may in fact be mere codifications of the lowest common denominator achievable across an array of states none of whom have internalized norms obligating conduct contrary to their independent preferences, and thus a high rate of observed compliance is not necessarily an objective indicator of a normative commitment to cooperate. By the same token, certain agreements that impose significant constraints may meet with relatively low levels of compliance without sabotaging the norms states-parties seek to advance. ${ }^{27}$ In short, the development of compliance theories requires that causal relationships between the normative fabric from which international legal obligations are woven and state behavior be clearly established. ${ }^{28}$

However, further complicating resolution of the debate between champions of the causal significance of international law and those who view law as epiphenomenal to state practice is the relative paucity of empirical studies testing general propositions regarding relationships between rules and behaviors. ${ }^{29}$ Although all social science theories are "indirect, presumptive, [and] obliquely and

\footnotetext{
${ }^{22}$ Williamson, supra note 20 , at 69.

${ }^{23}$ For a survey of competing theories, see W.E. BUTLER, CONTROL OVER COMPLIANCE WITH INTERNATIONAL LAW 195-96 (1991); see also EDITH BROWN WEISS, ED., INTERNATIONAL COMPLIANCE WITH NONBINDING ACCORDS 8 (2000). For an extended discussion of existing theories of compliance, see infra at pp._.

${ }^{24}$ See Daniel E. Ho, Compliance and International Soft Law: Why Do Countries Implement the Basle Accord?, J. INT'L ECON.

L. 647, 650 (intimating that states are chary of accepting legal obligations that significantly constrain behavior).

${ }^{25}$ Alvarez, supra note 5, at 305 (defining effectiveness and contrasting it with compliance).

${ }^{26}$ George W. Downs, David M. Rocke, \& Peter N. Barsoom, Is the Good News About Compliance Good News About

Cooperation?, 50 INT'L ORG. 379, 380 (1996). Much of international law may in fact be of this "self-enforcing" variety in that it obligates states to do nothing more than continue on as if unregulated by law. See ROGER FISHER, IMPROVING COMPLIANCE WITH INTERNATIONAL LAW 128-147 (1981).

${ }^{27}$ Kal Raustiala, Compliance and Effectiveness in International Regulatory Cooperation, 32 CASE W. RES. J. INT'L L. 387,388 (2000).

${ }_{28}$ "[E]ffectiveness," or the degree to which a legal regime induces changes in behavior that lead directly to improvement in the state of the underlying problem within a given issue-area, has been offered as the conceptual successor to compliance. Effectiveness studies assume that the rules of a regime can be effective even when compliance is low provided the regime imposes demanding behavioral transformations and correlations can be identified between the rules and such transformations. On the other hand, where compliance is high, yet a regime enshrines rules that simply mimic ongoing patterns of state practice, effectiveness is low. For a detailed discussion, see Raustiala, supra note 27. Although compliance and effectiveness are differentiable conceptually, the distinction is not theoretically significant to this Article.

${ }^{29}$ See Peter M. Haas, Choosing to Comply: Theorizing from International Relations and Comparative Politics, in DINAH SHELTON, COMMITMENT AND COMPLIANCE 44 (2000) ("Very little is known about the degree to which states comply with international commitments and empirical studies suggest that national compliance is uneven at best."); Jacobson, supra note 
incompletely corroborated at best[,] ${ }^{30}$ the field organized around the concept of international legal compliance is undernourished with insights from other disciplines: the few studies that describe patterns of compliance without tracing these relationships and establishing their effectiveness are insufficiently rigorous and too under-specified to offer many useful insights. ${ }^{31}$ To be sure, international law and international relations theorists have catalogued and described patterns of compliance. However, no ILC scholar has offered anything like the list of nomothetic propositions that one expects from a theory.

Moreover, insufficient rigor is not all that bedevils the field of ILC: the tacit assumption central to the discipline of international law that regards international relations as uniformly susceptible to legal regulation may well be false. A hierarchy of issue-areas ${ }^{32}$ orders the international legal system, and patterns of cooperation have been far easier to generate and sustain in respect to "low politics," generally understood as economic, cultural, and social issues, than in questions of "high politics," defined narrowly as matters of war and peace..$^{33}$ Because empirical evidence suggests that the obligations most breached are those trenching in questions of high politics, ${ }^{34}$ the ultimate test of whether international law matters may well be whether it can be crafted to regulate the "muscular aspects of international life." international relations are inevitably little more than a Hobbesian state of nature, and if war is inescapably the negation of the rule of law, then international law is and will always be epiphenomenal. If, on the other hand, states can be induced to comply with meaningful normative limitations on their conduct even in issue-areas that profoundly implicate their sovereignty, the long-deferred dream of a functioning civil society is no longer fanciful. Thus, if the laws of war, or international humanitarian law ["IHL"], are the soft underbelly of global legalization, ${ }^{37}$ developing a theory that can explain and predict IHL compliance and suggest ways in which it can be re-engineered to enhance its effectiveness is of great moment to the broader venture of making international law matter.

To note that this is no small undertaking is an understatement. Whether the gap between international law and state practice is closing, as legalization theorists believe, or widening, as their critics

18, at 571 ("Systematic knowledge about the extent of compliance of nations with the many international obligations they have accepted is relatively limited."); Raustiala \& Slaughter, supra note 8, at 548 (“[E]mpirical testing of compliance theories is limited. The lack of systematic, multi-case comparative studies has restricted the nature of the claims and prescriptions that compliance theorists can offer.").

${ }^{30}$ G.A. Almond \& S.J. Genco, Clouds, Clocks, and the Study of Politics, 27 WORLD POL. 489, 512 (1977).

${ }^{31}$ See Ryan Goodman \& Derek Jinks, How to Influence States: Socialization and International Human Rights Law, 54 DUKE L.J. 1 (2004) (concluding that the "first generation" of empirical international legal studies "has not adequately accounted for the regime design implications of this research" because it has left "unexamined or undefended empirical assumptions about foundational matters[.]"); Jack Goldsmith, Sovereignty, International Relations Theory, and International Law, 52 STAN. L. REV. 959984 (2000) (“international law scholarship suffers from . . . methodological unsophistication.”).

${ }^{32}$ See R.B. FARRELL, APPROACHES TO CONTEMPORARY AND INTERNATIONAL POLITICS 81 (defining "issue-area" as a cluster of interests and values in international relations organized around territory, status, resources, or norms).

${ }_{33}$ See STEPHEN KRASNER, INTERNATIONAL REGIMES 8, 173-76 (1983). For a discussion of the "high politics-low politics" distinction, see ROBERT O. KEOHANE \& JOSEPH S. NYE, POWER AND INTERDEPENDENCE 23-29 (1979).

${ }^{34}$ See Downs et al, supra note 26, at 379 (making this claim); see also David H. Moore, A Signaling Theory of Human Rights Compliance, 97 NW. U. L. REV. 879, 879 (2003) ("noncompliance is common . . . [and] the assumption of compliance may be the farthest from the truth" in issue-areas that challenge state sovereignty, such as human rights).

${ }^{35}$ BEDERMAN, supra note 3, at 190.

${ }^{36} \mathrm{IHL}$ is a set of "articulated norms, customs, professional codes, legal precepts, religious and philosophical principles, and reciprocal arrangements" that serves as the normative and positive structure of legal relations during armed conflict. MICHAEL WALZER, JUST AND UNJUST WARS 44 (1979).

${ }^{37}$ See HAZEL FOX \& MICHAEL MEYER, EDS., EFFECTING COMPLIANCE xiii ("[E]ffecting compliance with the law of armed conflict is . . a major contemporary challenge, a test of the so-called new world order[.]"); see also Steven R. Ratner, Overcoming Temptations to Violate Human Dignity in Times of Crisis: On the Possibilities for Meaningful Self-Restraint, 5 THEORETICAL INQ. L. 81, 83 (2004) (noting that the IHL regime "seem[s] the least effective of all international rules[.]"). 
insist, a great many scholars of diverse theoretical commitments agree that a "striking contrast [remains] between the richness of the normative order and the behaviour [sic] of men[.]"38 This contrast is most marked in the issue-area of IHL, where the record of compliance is, at best, mixed. ${ }^{39}$ It is thus especially regrettable that if the field of ILC is still a "primitive science, ${ }^{, 40}$ our ability to explain and predict the effectiveness of IHL is even more protean. ${ }^{41}$ While the relative youth of the broader field accounts for some of this theoretical underdevelopment, and the desire to retain parsimony for still more, ${ }^{42}$ the inability to explain and predict IHL compliance is primarily the result of a failure to specify the variables most closely associated with compliance decisions. That compliance studies designed by scholars of international law, a discipline that for centuries has reified states atop the hierarchy of subjects responsible for the generation, application, and interpretation of rules and norms, has paid short shrift to the causal significance of non-state levels of analysis, and particularly to the individual heads-of-state whose decisions are ultimately responsible for committing states to compliance with or violation of IHL, is unsurprising. However, IHL compliance, and compliance with international law more generally, will remain idiopathic phenomena so long as scholars fail to render a coherent body of testable hypotheses that permit empirical investigation of the entities directly and ultimately responsible for compliance.

In other words, the discipline of ILC must recognize that states are an abstraction utterly lacking in the capacity to exercise a choice between alternatives and that those who would answer the question, "Why do states choose to comply with or violate IHL?," must first ask and answer the prior, yet much more impenetrable, question: "Why do the individuals who exercise decisional authority commit their states to comply with or violate IHL?" States do not make decisions; people do. Any theory of IHL compliance that aspires to sufficient determinacy to guide practitioners and scholars alike must account for the individual level of analysis and in particular the microfoundations of personality that frame decisions and yield variation across the range of decisionmakers. Accordingly, Part I will briefly survey and critique existing pretheories of ILC generally and particularly with respect to IHL. ${ }^{43}$ Part II will present an alternative theory that draws from the insights of personality theory to trace the causal processes whereby the personalities of individual decisionmakers associate with decisions to comply with or violate obligations arising under the IHL regime governing the resort to anticipatory self-defense

\footnotetext{
${ }^{38}$ Hans-Peter Gasser, Ensuring Respect for the Geneva Conventions and Protocols: The Role of Third States and the United Nations, in FOX \& MEYERS, supra note 37, at 16.

${ }^{39}$ See James D. Morrow, The Laws of War, Common Conjectures, and Legal Systems in International Politics, 31 J. LEG. STUD. 41 (surveying IHL compliance); Posner, supra note 7, at 297 ("States frequently violate the laws of war[.]").

${ }^{40}$ See T. Millon, Normality: What May We Learn from Evolutionary Theory?, in The Diversity of Normal Behavior: Further Contributions to Normatology (D. Offer \& M. Sabshin eds., 1991), at 358 ("unrelated knowledge and techniques . . are a sign of a primitive science.").

${ }^{41}$ See George H. Aldrich, Compliance with the Law: Problems and Prospects, in FOX \& MEYERS, supra note 37, at 3 (stating that the failure to develop an effective legal regime is "the central problem confronting [IHL] today[.]"). Prediction in the social sciences may be a fool's errand, particularly when one sets sights on a highly contingent, rapidly evolving, and case-specific issue area wherein we must "account for unique details that cannot, both by laws of probability and time's arrow of irreversibility, occur together again.” STEPHEN JAY GOULD, WONDERFUL LIFE: THE BURGESS SHALE AND THE NATURE OF HISTORY 278 (1989). Nevertheless, to offer explanations without predictions would relegate the venture to mere post-hoc analysis rather than to the affirmative engineering of outcomes.

${ }_{42}$ A "parsimonious" theory is one that employs the fewest variables necessary to capture the underlying relationship between variables and expresses its hypotheses and findings in such a manner as to be readily understood and replicated.

${ }^{43}$ Any survey of existing literature in a burgeoning field is bound to merely skim the surface and to collapse some distinctions between theories while artificially creating others. The clusters surveyed are more complex than can be presented in the context of this Article, and there are points of intersection.
} 
["ASD"]. Part III will survey historical data to heuristically test the proffered theory, and Part IV, followed by a Conclusion, will anticipate criticisms and propose directions for further research.

\section{Theories of IHL Compliance: A Survey and A Critique}

ILC theories can be organized into six clusters: realism, enforcement theory, rational choice, institutionalism, liberalism, and normativism. ${ }^{44}$

\section{A. Theoretical Survey}

\section{Realism}

Realism assumes that the international system is immutably anarchic, that states will always be the sole relevant actors, and that a perpetual struggle for power obligates states, if they wish to preserve their territory and their existence, to maximize their relative power. ${ }^{45}$ Realists assert that international cooperation is possible only inasmuch as it reinforces the interests of states in maximizing their power and prospects for survival. ${ }^{46}$ Because state behavior is determined solely by structural factors-i.e., the relative balance of power-states will not pursue cooperation on the basis of normative commitments. The role of norms is, therefore, much abridged in an account that purports to explain all state behaviors as caused by transformation in the relative power distribution, and many realist scholars treat norms as entirely epiphenomenal.

Neither the role of the individuals that exercise command of the foreign policy apparatus of states nor their unique psychologies are of any theoretical interest to realism: even if they were not unknowable, motives and preferences would exert no causal influence on the behavior of decisionmakers who are presumed rational calculators of the relationship between state decisions and national power and committed to the singular pursuit of the latter. ${ }^{47}$ Moreover, regardless of their idiosyncracies, all decisionmakers choose identically, or nearly so, in response to external stimuli, and changes in the international system account for variations in foreign policy decisionmaking. ${ }^{48}$

Predictably, the role of international law is narrowly circumscribed in realist accounts of international relations. Although states may create international law as a pretext for decisions that in actuality serve their relentless pursuit of power ${ }^{49}$ or the subordination of weaker states, ${ }^{50}$ there are no norms capable of inducing states to voluntarily abridge their sovereign prerogatives, and those legal agreements into which states enter will be carefully and purposefully limited to peripheral matters that do not implicate their power or meaningfully limit their autonomy. ${ }^{51}$ Moreover, for realists compliance with international law is to a large degree a function of power: the more powerful a state, the less likely it will

\footnotetext{
${ }^{44}$ For a taxonomy of the various compliance pretheories, see Anthony Clark Arend, Do Legal Rules Matter? International Law and International Politics, 38 VA. J. INT'L L. 107, 114-19 (1998).

${ }^{45}$ See, e.g., HANS MORGENTHAU, POLITICS AMONG NATIONS: THE STRUGGLE FOR POWER AND PEACE (1948).

${ }^{46}$ See generally Hans J. Morgenthau, Positivism, Functionalism, and International Law, 34 AM. J. INT'L L. 260 (1940).

${ }^{47}$ See, e.g., KENNETH N. WALTZ, MAN, THE STATE, AND WAR 231-32 (1959) (dismissing "accidental causes" such as

"irrationalities in men" or norms or ideologies as of no consequence to theories of international relations).

${ }^{48}$ See generally JOHN MEARSHEIMER, THE TRAGEDY OF GREAT POWER POLITICS (2001).

${ }^{49}$ REINHOLD NIEBUHR, MORAL MAN AND IMMORAL SOCIETY 105 (1932).

${ }^{50}$ A number of scholars have suggested that the Western project of promoting the rule of law in places such as Bosnia, Kosovo, and Iraq has become a fundamentally imperialist enterprise in which foreign administrators backed by large armies govern societies pronounced unready to take on the task of self-governance, and that as such law serves realist ends. (note).

${ }^{51}$ Although realists accept that the existence of norms can alter the calculations of costs and benefits associated with policy choices, they reject the argument that norms have independent causal effects on state preferences and foreign policy decisions. See, e.g., Beth A. Simmons, Compliance with International Agreements, 1998 ANN. REV. POL. SCI. 75.
} 
suffer punishment from other states for its legal transgressions and the less likely it is, therefore, to comply with law or to agree in the first instance to be bound. Furthermore, because state survival is the superordinate value in the international system, realism predicts that compliance will correlate inversely with the degree to which the substantive rules place the territorial integrity, and thus the survival, of states at risk. $^{52}$ Finally, realism maintains that should state self-interest ever militate in favor of breaching legal obligations - in other words, should state self-interest ever cease to coincide with governing normsstates, which as realists remind us are nothing more than "legally sovereign unit[s] in a tenuous net of breakable obligations[,]" ${ }^{, 53}$ will invariably violate the law.

For realists, the strength of the general proposition that law exerts no independent causal influence on international relations ${ }^{54}$ is at a zenith in the context of IHL. Realism predicts that states will voluntarily accept only those constraints on their freedom to employ force that either enhance their relative power or that they intend to violate deliberately to their advantage. ${ }^{55}$ To the extent that it imposes restrictions on the methods and means states may employ in prosecuting their interests, particularly when rules distribute burdens asymmetrically or deny certain weapons or tactics that are likely to ensure survival, and to the degree that it limits the lawfulness of the resort to force in the first instance, especially when only the resort to force is likely to prevent political extinction at the hand of a stronger state, IHL is inimical to self-preservation. ${ }^{56}$

In sum, for realists it is axiomatic that armed conflict is a decidedly unfruitful arena in which to foster normative cooperation, and IHL cannot surmount the fact that it is an aspirational regime tangential at best to explanations of state behavior. Strong states do what they can, and weak states accept what they must. If law has a role in regulating armed conflict, it is through the extension of the domestic law of a powerful state, and this act itself is the assertion of power rather than of the power of a universal norm. ${ }^{57}$ Inter armes, silent leges. ${ }^{58}$

\section{Enforcement Theory}

Enforcement theory ["ET"] shares the core realist assumption that legalization is largely epiphenomenal to state behavior, particularly "when the [legal regime] tries to address issues for which an agreement is probably not enforceable." ${ }^{59}$ ET thus joins with realism in its skepticism toward the capacity to regulate high politics. However, ET departs from realism, principally on the questions of whether systematic cooperation is possible and whether measures short of the direct application of force or the

\footnotetext{
${ }^{52}$ See SHELTON, supra note 29, at 51 (noting that realism predicts that compliance will correlate with the degree to which a given legal regime challenges territorial integrity and will thus be strongest in the human rights issue area, followed by environmental issues, trade, and arms control in that order).

${ }^{53}$ STANLEY HOFFMAN, CONDITIONS OF WORLD ORDER 364 (1956).

${ }^{54}$ See Francis Boyle, The Irrelevance of International Law: The Schism Between International Law and International Politics, 10 CAL. W. INT'L L. J. 193 (1980) (summarizing realist position on relationship between law and power).

${ }^{55}$ See JEFFREY LEGRO, COOPERATION UNDER FIRE 10 (1999) ("States will desire mutual restraint when the balance of power implies relative disadvantage to first use (of a particular mode) of force. They will prefer escalation when the balance indicates relative advantage can be gained by first use."); Ryan Goodman \& Derek Jinks, Toward an Institutional Theory of State Sovereignty, 55 STAN. L. REV. 1751, 1766 (2003) (restating a realist tenet that states will "resist the influence of exogenously defined institutional constraints" that inhibit their power).

${ }^{56}$ See, e.g., Hans J. Morgenthau, The Twilight of International Morality, 58 ETHICS 79 (1948) (advocating the use of assassination as consistent with maximization of state interests).

${ }_{57}$ Alvarez, supra note 5, at 316 (describing utility of law in realism as limited to extraterritorial enforcement of domestic law).

58 "In time of war, the laws are silent." Attributed to Cicero, circa 50 B.C.

${ }^{59}$ Morrow, supra note 39, at 59-60.
} 
naked threat thereof can impel states toward compliance. Although it accepts that military sanctions may ultimately be necessary to hold states to their obligations, ${ }^{60}$ ET envisions the potential for a well-designed legal regime - even in IHL— to publicize clear rules, enhance monitoring, ${ }^{61}$ and institutionalize collective procedures for punishing violations, thereby enhancing the deterrent and coercive effects of a stable balance of power. ${ }^{62}$ Failures in compliance are thus, for ET theorists, failures to impose adequate punishment on prior violators. ${ }^{63}$

Still, while it is more optimistic as regards the possibility for international cooperation, ET theory clings fast to core realist assumptions: the greater the depth of intended cooperation in any given issuearea, and the greater the degree to which the territorial integrity or political independence is implicated by a contemplated legal regime, the harsher must be the consequences for violation of the primary rules. ${ }^{64}$ Consequently, ET regards as dubious the prospect that legal engineers can ever muster more than the shallowest of regimes in IHL without constant and vigilant monitoring ${ }^{65}$ and, even more vitally, a stalwart commitment from powerful states to swiftly punish violations.

\section{Liberalism}

Liberalism shifts the inquiry from the systemic balance of power to the domestic level of analysis and posits that the key actors in international relations, and thus the primary independent variables in regard to compliance, are not states but rather individuals, institutions, organizations, and other components of civil society. ${ }^{66}$ Rather than accept the realist presumption that states are unitary actors consumed by the pursuit of power, liberalism contends that it is the nature of the domestic politics that predominate within state borders that determines the composition of representative governments and in turn the willingness of states to subordinate sovereignty to normative regulation. ${ }^{67}$ Rather than attribute causation to exogenous factors, liberalism regards state behaviors as a function of the manner in which

\footnotetext{
${ }^{60}$ See Moore, supra note 13, at 887 ("In a system lacking adequate centralized mechanisms ...., permitting the parties to ... take responsive countermeasures may be one of the most important mechanisms . . . for encouraging compliance[.]").

${ }^{61}$ See SHELTON, supra note 29, at 5 (stressing the centrality of monitoring measures to ET).

${ }^{62}$ See Morrow, supra note 39, at 41-42 (elaborating the preconditions specified by ET for an effective compliance regime); see also Richard Baxter, Forces for Compliance with the Law of War, AM. SOC. INT'L L. 82, 82-83 (1964) (stressing that the threat of punishment-individual and collective-is a crucial support mechanism to the enforcement of international law generally and IHL specifically). Punishment need not be meted out by international institutions: ET contemplates that domestic prosecution of violators of IHL can suffice to deter and prevent future violations. Id.

${ }^{63}$ See, e.g., Robert A. Bailey, Why Do States Violate the Law of War? A Comparison of Iraqi Violations in Two Gulf Wars, 27 SYRACUSE J. INT'L L. \& COM. 103, 104 (2000) (linking erosion of deterrence created by the prosecution of Nazi defendants at Nuremburg to subsequent failures to enforce IHL). ET theorists link failures of law more generally to the minimal probabilities that violations will be discovered and their authors identified and punished. See Tom R. Tyler, Compliance with International Property Laws: A Psychological Perspective, 29 N.Y.U.J. INT'L L. \& POL. 219, 222 (1997) (describing the objective risk of detection, apprehension, and prosecution as very low in regard to almost all crimes).

${ }^{64}$ Downs et al., supra note 26, at 379-80; see also Jack Goldsmith, Sovereignty, International Relations Theory, and International Law, 52 STAN. L. REV. 959, 979 (2000) (stressing that sanctions best promote compliance).

${ }^{65}$ ET theorists reposit some confidence in measures established under relevant IHL treaties to publicize the content of the substantive rules, develop information and find facts with regard to allegations of breaches, resolve disputes, and hold individual violators legally accountable for their actions. See, e.g., FOX \& MEYER, supra note 37, at xiv-116 (describing "important" mechanisms that aid IHL enforcement). Still, the crucial element of compliance, viewed through the ET prism, is robust sanctions, particularly of the military sort.

${ }^{66}$ See generally Andrew Moravcsik, Taking Preferences Seriously: A Liberal Theory of International Politics, 51 INT'L ORG. 513 (1997); Anne-Marie Slaughter, The Liberal Agenda for Peace: International Relations Theory and the Future of the United Nations, 4 TRANSNAT'L L. \& CONTEMP. PROBS. 377, 397-400 (1994). Liberalism is very much a theory of elite political participation: because not all issues resonate uniformly within the polity, maximizing the intensity of individual preferences and mobilizing political support, along with stifling dissent, is at least as significant as is creating a political majority. See SHELTON, supra note 29, at 47 ("Compliance is . . . a matter of choice by the state to discipline civil society, often at the request of activist sources in civil society.").

${ }^{67}$ Moravcsik, supra note 66, at 513 ("Societal ideas, interests, and institutions . . . shap[e] state preferences[.]").
} 
states are internally constituted. Because it theorizes democracies as inherently more committed to the "rule of law," ${ }^{68}$ more prone to absorb international legal obligations into their domestic legal orders and to diffuse these obligations through foreign policy bureaucracies, and more willing to permit interest groups to mobilize mass electoral support for international legal norms than non-democratic states, liberalism predicts that democracies are more likely to accept and honor international legal obligations ${ }^{69}$ and less likely to engage in armed conflict in the first instance. ${ }^{70}$

Moreover, because it regards compliance as a function of the degree to which the aggregation of the preferences of key domestic individuals and groups directs the representative state toward normfollowing and legal regulation, liberalism predicts that IHL compliance is likely to be maximized by programs that alter domestic preferences in favor of democratization independently of the substantive norms at the heart of the IHL regime. ${ }^{71}$ Foremost among such measures are packages of domestic legislation that internalize international legal norms, "blur" the distinction between international and domestic $^{72}$ and obligate officials to observe universal normative prescriptions as a matter of domestic law. ${ }^{73}$ Thus, by inducing democratic commitments to IHL norms, such programs encourage elected leaders to translate domestic preferences into official policies limiting the resort to force ${ }^{74}$ and constraining methods and means ${ }^{75}$ while compelling them to conform their conduct in battle to the rules these norms reflect.

\section{Rational Choice}

Although no universally accepted definition of "rationality" has yet been propounded, ${ }^{76}$ various "rational choice" theories ["RCT"] converge around a core set of assumptions and premises: (1) individuals pursue their material self-interests by the means they calculate as most likely to attain objectives at the lowest costs; (2) individuals search for information, evaluate outcomes and probabilities, and make purposive choices as to means, but not as to ends, for welfare maximization is the

\footnotetext{
${ }^{68}$ See Philip Trimble, International Law, World Order, and Critical Legal Studies, 42 STAN. L. REV. 811, 842 (1990) ("Some societies [i.e., liberal democracies] are more dedicated to legalism and the 'rule of law' than others.).

${ }^{69}$ See, e.g., HENKIN, supra note 6, at 62 (contending that liberal states are more likely to honor international legal obligations than are illiberal states); Hathaway, The Cost of Commitment, Yale Law School, Working Paper Series 274 (April 1, 2003), at 116 (contending that even where there are few external incentives, such as sanctions, for states to comply with international legal obligations, many democracies will comply because domestic constituencies will impose internal (i.e., electoral) sanctions if they do not). For a critique of liberalism as a "culture of law," see Jose E. Alvarez, Do Liberal States Behave Better? A Critique of Slaughter's Liberal Theory, EUR. J. INT'L L. 183, 184 (2001).

${ }^{70}$ For an analysis of research suggesting that democracies are less war-prone than non-democracies, along with an explanation for this phenomenon, see generally JOHN NORTON MOORE, SOLVING THE WAR PUZZLE (2004).

${ }^{71}$ See Posner, supra note 7, at 314 (analyzing state ratifications of IHL treaties and concluding that democracies are "more enthusiastic" about IHL than non-democracies). In the liberalist account, nongovernmental organizations marshal domestic support for IHL compliance and deploy that pressure against governments. ABRAM CHAYES \& ANTONIA CHAYES, THE NEW SOVEREIGNTY 21 (1995).

${ }_{72}^{72}$ FISHER, supra note 26, at 142 (describing this process as securing "first-order compliance").

${ }^{73}$ Williamson, supra note 20, at 80-81.

${ }^{74}$ See generally Zeev Maoz \& Bruce Russett, Normative and Structural Causes of the Democratic Peace, 87 AM. POL. SCI.

REV. 624 (1993) (contending that the type of regime has a dampening effect on participation in armed conflict and that democracies are inherently more peaceful).

${ }^{75}$ See Kahler, supra note 9, at 677 (2000) (illustrating connections asserted by liberalists between domestic opinion and state military policies).

${ }^{76}$ See Amartya Sen, Rational Fools, in SCIENTIFIC MODELS AND MAN (H. Harris ed., 1979) at 1, 5. For a general discussion of the origins of rational choice theory, along with an examination of early theoretical divisions within rational choice scholarship that continue to bifurcate the theoretical plain, see HERBERT SIMON, MODELS OF MAN (1957).
} 
predetermined preference of each decisionmaker; ${ }^{77}$ (3) although individuals are not perfect processors of information, ${ }^{78}$ they possess the analytic capacity to choose the alternative most likely to contribute to their welfare ${ }^{79}$ (4) neither norms nor any other idiosyncratic elements of personality account for individual behaviors ${ }^{80}$ rather, behavioral regularities that come to be labeled as "norms" are in reality the result of individuals pursuing self-interests; ${ }^{81}$ (6) states act as unitary actors through the decisions of key individuals or groups $;{ }^{82}(7)$ state actions are the product of the decisions of a single individual or a small group of crucial individuals who possess the authority, or at least the power, to commit the state ${ }^{83}$ and (8) state decisions are egoistic choices undertaken to advance the material self-interests of these key individuals and groups along with the populations of which they are representative. ${ }^{84}$

Because the rational pursuit of self-interest is the explanandum of behavior, law is theoretically significant within RCT explanations only insomuch as it alters the relative costs of particular means: in other words, legal rules alter the payoff structure of certain strategies and decisions, and decisions about compliance are evaluated on materialist, rather than normative, grounds. States will not comply altruistically, yet noncompliance may be costly if other states impose economic or military sanctions. ${ }^{85}$ In essence, if legal architects craft a formula that converges state interests with the rules of the regime and ensures that effective sanctions are available to deter defections through the imposition of costs that exceed the gains to be had through violations, ${ }^{86}$ an effective regime can be sustained. RCT thus explains compliance with legal rules in starkly instrumental terms: if compliance is the decision strategy most likely to yield the greatest benefit, a state will comply; conversely, if violation of the law is the strategy

\footnotetext{
${ }^{77}$ See, e.g., Robert O. Keohane, International Relations and International Law: Two Optics, 38 HARV. INT'L L.J. 487 , 495

("The basic [RCT] heuristic is to attribute observed behavior to the rational pursuit of self-interest.").

${ }^{78}$ Only a very few RCT scholars regard the individual as homo economicus, an "omniscient calculator who can easily perform all cognitive calculations necessary to reach decision.” DAVID O. SEARS, LEONIE HUDDY, \& ROBERT JERVIS, EDS., OXFORD HANDBOOK OF POLITICAL PSYCHOLOGY 24 (2003). Most take a more "bounded" approach and accept that imperfect reasoning does not defeat the procedural rationality of individual decisions.

${ }^{79}$ Benedict Kingsbury, The Concept of Compliance as a Function of Competing Conceptions of International Law, $19 \mathrm{MICH}$. J. INT'L L. 345, 349 (1998).

${ }^{80}$ See ERIC A. POSNER, LAW AND SOCIAL NORMS 46 (rejecting the causal significance of the "cauldron of instincts, passions, and deeply ingrained cultural attitudes" in relation to the generation of social norms or the explanation of behavior). For RCT scholars, parsimony and investigability override efforts to build norms into their enterprise, and nonrational sources of preference and motivation are considered "just not well enough understood by psychologists to support a theory of social norms, and repeated but puzzled acknowledgments of their importance would muddy the exposition of the argument without providing any offsetting benefits." Id.

${ }^{81}$ See KRISTEN RENWICK MONROE, ED., CONTEMPORARY EMPIRICAL POLITICAL THEORY 284 (1997) (describing the RCT position that behavior is independent of norms and that the proclivity to engage in norm-neutral patterns of individual wealth maximization "constitutes a universal, even a defining, characteristic of humanity."). "Thin" versions of RCT, which ignore social values, symbols, and normative practices central to theories of social ontology, predominate in the international relations and international legal literature; so-called "thick theories," which make room for detailed descriptions of norms, values, cultural assumptions, metaphors, religious beliefs, and personal commitments, have heretofore been either subsumed into other paradigms or largely overlooked in the literature.

${ }^{82}$ See BRUCE BUENO DE MESQUITA, THE WAR TRAP (1981) (arguing that top executive decisionmakers represent the state).

${ }^{83}$ See Peter H. Huang, International Law and Emotional Rational Choice, 31 J. LEG. STUD. 237, 241 (2002).

${ }^{84}$ YOUNG, supra note 10, at 18.

${ }^{85}$ See POSNER, supra note 80, at 8 (explaining that RCT posits that sanctions alter preferences in the direction of compliance). Noncompliance may also trigger indirect costs, as a habit of violation may dissuade other states from joining with the noncomplier to resolve collective action problems, such as the establishment of security or environmental regimes. Posner, supra note 7, at 309. However, in many issue-areas, and in particular in regard to the issue of territorial integrity, the price of a bad reputation may well be lower than in more cooperative issue-areas, such as trade. $I d$.

${ }^{86}$ See Jack A. Goldsmith \& Eric A. Posner, A Theory of Customary International Law, 66 U. CHI. L. REV. 1113, 1114-15 (1999) (rejecting the argument that legal rules exert any compliance pull per se and stressing that convergence of state interest and legal rules, and not widely shared norms, are essential to an effective regime).
} 
most conducive to the maximization of welfare, it will violate the law even if other states stand ready to apply sanctions or impose reputational costs. Norms do not command compliance; power does.

If the effectiveness of international law hinges upon the convergence of regime rules with the self-interest of states or with the threat or use of the ultimate sanction, one would not anticipate that IHL, a series of rules that limits the circumstances under which resort to force is lawful and the methods and means that may be employed, would secure much compliance from states whose leaders are committed not to the norms undergirding these rules but to the maximization of their security, wealth, and power in an anarchic international system. ${ }^{87}$ IHL is effectively a pre-war agreement to abstain from enumerated "battle strategies," and RCT predicts that states will comply with rules that limit the resort to particular methods or means only if the benefits gained through the resort to these methods or means are less than the costs imposed by third states, whether reputational or, more likely, economic and military. ${ }^{88}$ States will readily consent to the proscription of methods and means that have little inherent operational utility and thus do not favor one state over another, ${ }^{89}$ or that they are unable to employ due to an inability to produce or fund the relevant technology. ${ }^{90}$ States will also consent to constraints on the use of weapons that are not cost-effective in that they consume significant resources to produce without contributing sufficiently to the destruction of the enemy. However, states will either withhold consent to the prohibition of battle strategies the benefits of which, by their subjective calculations, outweigh the sum of the costs of their retaliatory use by enemies plus the costs of external sanctions, ${ }^{91}$ or state consent to such prohibitions will itself constitute a battle strategy: devious states will take whatever gains are available from the first use of methods and means they fraudulently disclaimed against their duped enemies.

Specifically, RCT has explained a general pattern of state compliance with rules governing the treatment of POWs not in terms of fundamental shared conceptions of humanity but as consistent with calculations that humane treatment of enemy POWs will encourage enemy soldiers to surrender and thereby terminate the conflict quickly and on favorable terms. ${ }^{92}$ Differential rates of compliance suggesting that wealthier states are more prone to observe rules regarding POWs are rationalized as consistent with the greater material capacities of resource-rich states to comply with expensive obligations to properly house, transport, and interrogate enemy captives; for wealthy states, if their compliance promotes enemy surrenders, it may register as cost-neutral or even as a gain, whereas for poor

\footnotetext{
${ }^{87}$ See Posner, supra note 7, at 308-09 (denying that "humanity," other normative considerations, or legal rules themselves exert causal influence on state compliance decisions in regard to IHL).

${ }^{88}$ Morrow, supra note 39, at 46. RCT scholars discount the importance of reputational sanctions in the armed conflict issue-area as under conditions of war states define welfare maximization in terms of the enhancement of their survival and power rather than in terms of their social standing. See Posner, supra note 7, at 309 ("Neither reputational concerns nor interior controls ... have much influence on the conduct of states during war."). Because reputational costs matter little, IHL is thus enforceable only "to the extent that nations ... retaliate against belligerents who violate [it.]" Id. at 297.

${ }^{89}$ Morrow, supra note 39, at 46. RCT assumes that states will not spend resources on war if they can dedicate them to civilian expenditures instead, and that states will thus eschew battle strategies of little martial benefit if in so doing they can generate "greater production and consumption for civilians than would occur if military investment were unconstrained." Posner, supra note 7 at 314 .

${ }_{90}$ In other words, each method and means of warfare has distributional effects in that it does not benefit all states equally, and RCT predicts that each state will seek to ban those methods and means that exceed its technological sophistication or that it believes will be more effective in the hands of other states than in its own. Id. at 305, 310-312.

${ }_{91}^{91}$ See id. at 297, 299-302 (indicating that some prohibited battle strategies, such as targeting civilians and civilian property, may aid a violator in terminating a war quickly on favorable terms, while others, such as the feigning of surrender to lure enemy troops into the open only to dispatch them, favors the weaker of two belligerents).

${ }^{92} I d$. at 312. At worst, compliance with the rules supports reciprocity, and the net cost of this strategy is zero. Id. at 308.
} 
states compliance consumes resources better directed toward the destruction of the enemy, and violation of rules concerning POWs is an efficient battle strategy.

Furthermore, the remarkably stable and general pattern of compliance with rules prohibiting CWs, a low-cost, incredibly effective weapons system, is susceptible to explanation by RCT. Wealthy states will support bans on cheap and effective weapons per se in order to deny as many useful methods to poorer states as possible, ${ }^{93}$ and all states will have little incentive to employ terribly destructive yet technologically unsophisticated and widely available weapons from the use of which little advantage, due to the likelihood of retaliation in kind, will accrue to either side. RCT speaks not only to means but to methods: the customary principles of military necessity, ${ }^{94}$ proportionality, ${ }^{95}$ and distinction ${ }^{96}$ are nothing but the result of continuous pressure placed upon more powerful states by less powerful states seeking, under the guise of professions of humanitarian concern over unnecessary suffering attendant to war, to force the former to employ less potent weapons readily available to the latter and thus to tilt the battlefield toward equilibrium. ${ }^{97}$

Finally, RCT accounts for a generalized failure of compliance with rules limiting the resort to force in the first instance, also known as the jus ad bellum, ${ }^{98}$ by simply noting that, although in theory states can converge their interests to form a collective security regime, ${ }^{99}$ in practice states have calculated that their interests in survival, wealth preservation, or power maximization have been better served by engaging in the unauthorized use of force..$^{100}$

\section{Institutionalism}

Institutionalism can be disaggregated into three interrelated theories: managerialism, reputational theory, and transnational legal process.

a. Managerialism

Managerialism ["MT"] can be distilled into the following series of premises: (1) the long-term interests of states are best served through cooperation on collective action problems; (2) states are naturally imbued with a propensity to comply with legal rules because a reputation as an international "good citizen" is intrinsically valuable ${ }^{101}$ and because violations may result in exclusion from the benefits

\footnotetext{
${ }^{93} I d$. at 303 (postulating that IHL prohibitions on weapons systems will be "directed foremost at the most efficient weapons", defined as those with the highest ratio of military effectiveness to cost, e.g., CWs).

${ }^{94}$ The customary IHL principle of necessity implicitly authorizes all operations undertaken in the immediate interest of selfpreservation provided a minimal threshold requirement - that they be intended and tended directly toward the military defeat of the enemy-is satisfied. See A.P.V. ROGERS, LAW ON THE BATTLEFIELD 5 (1995) (defining military necessity as "the principle that a belligerent is justified in applying compulsion and force of any kind, to the extent necessary for ... the complete submission of the enemy[.]"

${ }_{95}$ The customary IHL principle of proportionality, designed to shield civilians from the suffering of war, dictates that military force not be employed to cause damage excessive in relation to the concrete and direct military advantage anticipated. R.R.

Baxter, Modernizing the Law of War, 78 MIL. L. REV. 165, 178-79 (1972) (defining proportionality).

${ }^{96}$ The customary IHL principle of distinction, which maintains that the only legitimate object of war is to destroy enemy armed forces, imposes a strict prohibition against the deliberate targeting of noncombatant personnel and civilian targets. See Christopher C. Burris, Re-Examining the Prisoner of War Status of PLO Fedayeen, 22 N.C.J. INT'L L. \& COMM. REG. 943 , 966 (1987) (discussing origins and application of principle of distinction).

${ }^{97}$ Posner, supra note 7 , at 302 .

${ }^{98}$ See infra at pp._.

${ }^{99}$ See STEPHEN KRASNER, INTERNATIONAL REGIMES 173 (1983).

${ }^{100}$ See e e.g., Eric A. Posner \& Alan O. Sykes, Optimal War and Jus Ad Bellum, Public Law and Legal Theory Working Paper No. 63 (April 2004), at 10-13, available at http://ssrn.com/abstract_id.=546104.

${ }^{101}$ See Moore, supra note 34, at 880.
} 
associated with cooperation; ${ }^{102}(3)$ norms widely perceived as fair and equitable and therefore legitimate ${ }^{103}$ are responsible for tapping into this natural propensity and fostering cooperative legal arrangements; (4) instances of noncompliance with international law are the exception rather than the rule $;^{104}(5)$ most noncompliance is the result not of deliberate violation but rather of a lack of precision in specifying obligations in ambiguous or indeterminate treaties, a lack of technical capacity that prevents states willing to comply from physically doing so, or fundamental changes in circumstances that render compliance impossible ${ }^{105}$ (6) states' inherent preference for compliance defends legal regimes against decay in the face of violations: most states will continue to observe international legal obligations even if some states do not, ${ }^{106}$ and thus perfect compliance is unnecessary to define a legal regime as effective; ${ }^{107}$ (7) because states are interested in and prone to cooperation, compliance failures are remediable not through enforcement — an expensive "waste of time" 108 — but by consultation, negotiation, and persuasion; when disputes or defections occur, non-coercive methods alone are sufficient to adjust preferences and steer states back into conformity; ${ }^{109}$ and (8) because noncompliance is largely unintentional, the problem is neither structural nor rooted in divergent preferences but managerial—enhancement of regime effectiveness therefore requires enhancement of the capacities of weaker and poorer states and the removal of obstacles to compliance, formalization and clarification of legal obligations to render rules more compelling internalization of international norms in domestic legislation, and dissemination of

\footnotetext{
${ }^{102}$ See CHAYES \& CHAYES, supra note 71 (contending that the threat of alienation from a "complex web of international arrangements" that have become "central to most states' security and economic well-being" fosters compliance).

${ }^{103}$ See id. at 127 (defining "legitimacy" as a relative judgment that a norm "emanates from a fair and accepted procedure, ... is applied equally and without invidious discrimination, and . . . does not offend minimum substantive standards of fairness and equity."). MT predicts that the greater the clarity and "wisdom" of a given rule, the more likely states will be to accord it their compliance. Williamson, supra note 20, at 62.

${ }^{104}$ CHAYES \& CHAYES, supra note 71, at 9. The question of partial compliance can be answered to support the MT contention that compliance is the norm: partial compliance requires an interpretive judgment as to whether performance has met the legally obligated standard, and MT scholars are loathe to find noncompliance:

$[T]$ here is a considerable zone within which behavior is accepted as adequately conforming ... An "acceptable level of compliance" is not an invariant standard. It changes over time with the capacities of the parties and the urgency of the problem. It may depend on the type of treaty, the context, the exact behavior involved. The matter is further complicated because, for many legal norms ... questions of compliance are often contestable and call for complex, subtle, and frequently subjective evaluation.

Id. at 17.

${ }^{105}$ Downs et al, supra note 26, at 380. Recent MT scholarship suggests that compliance with certain multilateral treaties may benefit from overt recognition of the principle of "common but differentiated responsibilities" ["CDR"] which provides that states will vary with regard to their technical and economic capacities for implementation and that the formal rules, or at least interpretations of compliance, must take into consideration inequalities in capacities. See, e.g., Christopher D. Stone, Common But Differentiated Responsibilities in International Law, 98 AM. J. INT'L L.276 (2004). Whether the principle of CDR would attenuate the obligation to comply with treaties that codify norms of jus cogens or provide for important public goods has as yet not been subject to theoretical inquiry. Id. at 301 .

${ }^{106}$ CHAYES \& CHAYES, supra note 71, at 19.

${ }^{107}$ See Raustiala \& Slaughter, supra note 8, at 542 (explaining that for MT scholars compliance is a "continuum with the appropriate or tolerable level of compliance set through an interactive, sometimes tacit process[,]" and that some regimes are very tolerant of noncompliance). MT views international legal regimes as flexible enough to sustain some degree of noncompliance without breaking, particularly if necessary to maintain prevent powerful states from abandoning them. See Jeol P. Trachtman, Bananas, Direct Effect and Compliance, EUR. J. INT'L L. (1999) ("It is a realistic recognition that law and politics must coexist, and that the nirvana of perfect compliance is a chimera.").

${ }^{108}$ CHAYES \& CHAYES, supra note 71, at 2 (arguing that military sanctions expend too many lives and too much treasure, and economic sanctions are too slow and ineffective, to secure compliance with the vast majority of legal regimes).

${ }^{109}$ See ROBERT KEOHANE, AFTER HEGEMONY 51 (1979).
} 
normative content through institutions and training programs. ${ }^{110}$ In sum, MT states will comply with legal regimes if only they are properly organized by powerful states willing to bear management costs. ${ }^{111}$

For MT scholars, IHL is just another legal regime, and proper management is key to its effectiveness. Well-elaborated treaty instruments that plainly remove particular battle strategies from the repertoire of ratifying states will generate strong incentives toward compliance of their own accord, ${ }^{112}$ even under conditions of uncertainty as to the conduct of enemies that appertain during the "fog of war." 113 Although it does not predict perfect compliance - a distinction is drawn between individual violations not sanctioned by the state on the one hand and official state policies authorizing violations on the other, ${ }^{114}$ and urges tolerance in respect to localized "feuds of reciprocal punishments" carried out by limited numbers of combatants in order to preserve the regime ${ }^{115}$--MT contends that the creation of treatybased monitoring and verification mechanisms to capitalize upon the inherent proclivity of states to honor their substantive obligations is an effective approach to facilitating cooperation even during war. ${ }^{116}$ Enforcement measures, such as reprisal, are therefore to be used sparingly and, because they are of the most limited utility, only where management fails.

\section{b. Reputational Theory}

For adherents of reputational theories ["RT"], reputation, the "bulwark for the maintenance of commitments," matters. States, just as individuals, wish to claim the respect of their peers and avoid their reprobation, ${ }^{117}$ and considerations of national honor and prestige play an important role in restraining selfinterested state behavior. ${ }^{118}$ Therefore, states do not lightly enter into international agreements, but tend to

\footnotetext{
${ }^{110}$ See Raustiala, supra note 27, at 293 (describing the MT agenda for enhancing compliance through greater specification and implementation of regime norms and rules).

${ }^{111}$ Management costs typically involve supporting the institutions necessary to harmonize interests, facilitate negotiations, and provide monitoring and information dissemination. See generally Keohane, supra note 77.

${ }^{112}$ See James D. Morrow, The Institutional Features of the Prisoners of War Treaties, 55 INT'L ORG. 971, 973 (2001)
} (explaining that IHL "sways actors' decisions about which strategies they will use in pursuit of victory.").

${ }^{113}$ IHL poses a "two-level problem" in that compliance is a function not only of official state choices but of the fidelity of individual combatants to the prescriptions and proscriptions established by IHL instruments as well as to the orders of their governments. MT scholars term uncertainty as to the compliance of other states as "noise" and concede that the battlefield is a particularly noisy place; however, the source of noise on the battlefield — whether state decisions or individual violations-is difficult to attribute without unavailable information. For MT scholars legal regimes permit states to resolve the ignore reports of low-level violations of agreements by presuming that other states remain committed to the legal regime in question and that violations are not attributable to the state but rather to individual noncompliers. See Morrow, supra note 39, at 52 (noting that individual violations may be difficult to discover and to prove, that even if proven may be contrary to state policy, and that the evaluation of state compliance with IHL is thus a strategic problem difficult to resolve without a theory of agency).

${ }^{114}$ See id. (explaining that while "[t]here will always be some violations when the policing of individuals is critical for an issue" under MT "[t]he management of individual violations is generally left to the militaries of those violators.").

${ }^{115}$ Morrow, supra note 113, at 975-76.

${ }^{116}$ See id. at 982 (pointing to treaties establishing neutral third-parties as fact-finders, protecting powers, and other formal procedures for developing information as mechanism for managing compliance with IHL).

${ }^{117}$ See Steven R. Ratner, Precommitment Theory and International Law: Starting a Conversation, 81 TEX. L. REV. 2055,2064 (2003) (stressing that although fear of reprisal is an important constraint on state compliance decisions, the desire to avoid shame associated with violating law is a significant consideration); YOUNG, supra note 10, at 22 (contending that states are sensitive to social pressures and seek to avoid ostracism while gaining from peers their social approval, extension of status, and friendship). More general research suggests that most social norms are observed to maintain and enhance status within a peer group rather than to avoid punishment. See B. Douglas Bernheim, A Theory of Conformity, 102 J. POL. ECON. 841, 841-44 (1994) (arguing that individuals conform "because they recognize that even small departures from the norm will seriously impair their popularity."). For a discussion of the role of social norms as they relate to law, see generally ROBERT ELLICKSON, ORDER WITHOUT LAW (1991); Harold G. Grasmicj \& Robert J. Bursik, Conscience, Significant Others, and Rational Choice: Extending the Deterrence Model, 24 L. \& SOC'Y REV. 837 (1990).

${ }^{118}$ See Tyler, supra note 63, at 225 (noting importance of peer groups in fostering compliance with legal norms); Williamson, supra note 20, at 81 (suggesting states have an interest in "fostering a reputation for reliability in the eyes of other [states]"); Keohane, supra note 77, at 490 (“In an interdependent . . . world, a reputation for reliability matters."). 
observe those legal obligations they do undertake ${ }^{119}$ and to undertake those obligations widely deemed by other states to be constitutive of the "modern or civilized state." 120 Treaties are thus screening devices: by accepting legal obligations and honoring them, states demonstrate to the international community that they are good international citizens and deserve inclusion in cooperative regimes; ${ }^{121}$ conversely, by refusing to accept a legal obligation, a state "signals" to other states its rejection of community normative standards and self-classifies as an outlier from the pattern of norm-governed international relations. ${ }^{122}$ Because most states do not wish to forfeit the reputational benefits of association with "good" states or incur the reputational costs of being classified with "bad" states, ${ }^{123}$ and because some states are eager to publicly signal their approval of the normative content of certain kinds of legal obligations, ${ }^{124}$ RT explains ratification of treaties as a process whereby states demonstrate, protect, and enhance their reputations. ${ }^{125}$

Within RT theory, the very act of undertaking an international legal obligation, whether through ratification of a treaty or supporting a declaration of custom, positively affects state incentives. ${ }^{126}$ Although the choice to comply with a legal obligation may be costlier in material terms than noncompliance, the reputational harm self-inflicted by a violation is costlier still in many instances. ${ }^{127}$ While RT concedes that some states, desirous of the reputational gains that accrue upon signaling their acceptance of legal norms, may prove incapable or even unwilling to meet their obligations in practice, ${ }^{128}$ it maintains that most states will comply with regimes even when rules conflict with their short-term selfinterests because the process of socialization with other states effectively redefines self-interest and motivates states to wish to protect a reputation for compliance. ${ }^{129}$ At worst, states will attempt to justify or explain away their violations of law as somehow either faithful to the spirit (if not the letter) of the legal rule in question or as having occasioned only de minimis harm. ${ }^{130}$ In a real sense, compliance, viewed through the RT lens, is "herd behavior" ${ }^{131}$ secured through strategic mobilization of peer pressure.

As to IHL, RT makes no specific claims, yet some RT theorists concede that the potency of reputational effects is probably lowest in issue-areas where the stakes are highest and that for states the benefits that accrue from being perceived as a rule-follower are far less than the gains to be had through the election of prohibited but highly useful battle strategies. In other words, short-term gains relative to

\footnotetext{
${ }^{119} I d$. That states generally defend their legally dubious conduct as lawful is proferred by RT theorists as further support for the conclusion that reputation matters. BEDERMAN, supra note 3, at 21.

${ }^{120}$ Goodman \& Jinks, supra note 55, at 1778.

${ }^{121}$ See Ho, supra note 24, at 654 (describing a reputation for compliance in the field of trade as a "stamp of approval").

${ }^{122}$ This is a simplification: RT creates a $2 \times 2$ matrix into which states are assigned, on the basis not only of ratification but also of subsequent practice, as either 1) acceding and complying, 2) acceding but noncomplying, 3) nonacceding yet complying, and 4) nonacceding and noncomplying. See Moore, supra note 34, at 903 (modeling a RT of compliance).

${ }^{123}$ See id. at $902-03$ (positing that some states accede to legal obligations because failure to do so "risks the cost of being classed with unrestrained states.").

${ }^{124}$ See Hathaway, supra note 12, at 1941 (describing ratification of treaties as in part an "expressive" process whereby states declare their solidarity with normative positions embodied in those instruments).

${ }^{125}$ See Ratner, supra note 118, at 2058 (elaborating an RT explanation of state ratifications of multilateral treaties).

${ }^{126}$ Guzman, supra note 4, at 1828.

${ }^{127}$ See Simmons, supra note 51, at 835 (hypothesizing that the mere existence of a legally binding rule changes the context for decisionmaking by imposing reputational costs on decisions not to comply).

${ }^{128}$ See SHELTON, supra note 29, at 45 (conceding that the rare state will be immune from reputational costs and will comply only in the face of military or economic sanctions).

${ }^{129}$ See Goodman \& Jinks, supra note 31, at 53 (defining the central problem in ILC as "how best to socialize "bad actors"”).

${ }^{130}$ See Guzman, supra note 4, at 1830 (noting that states accused of violations of law "proclaim [their] innocence or expend resources fighting to exonerate themselves[.]").

${ }^{131}$ POSNER, supra note 80 , at 41.
} 
enemy states are far more valuable than long-term reputational considerations, ${ }^{132}$ and when threatened, states will do whatever they deem necessary to ensure their territorial integrity and political independence; only if they survive do they worry about what other states think of them.

\section{c. Transnational Legal Process}

Transnational legal process theory ["TLP"] shares the realist premise that states are unitary rational actors in an anarchic system but nonetheless insists that states are in fact inclined toward cooperation and that international legal norms emerge through patterns of state cooperation. ${ }^{133}$

International legal regimes clarify and formalize patterns of cooperative behavior, transforming state incentives and conditioning further cooperation on compliance with rules within and across various issueareas ${ }^{134}$ at the same time, transnational epistemic communities consisting largely of foreign policy elites arise to internalize cooperative norms and rules in domestic law and legal institutions, a process that deepens cooperation still further. ${ }^{135}$ It is this parallel process of institutionalization in international and domestic fora that accounts for the creation and internalization of legal norms and rules and the progressive evolution of cooperation.

For TLP theorists, compliance is a function of the degree to which a given legal regime is internalized in domestic law. Variance in rates of state compliance is thus the result of variance in rates and degrees of incorporation of the relevant international legal regime. ${ }^{136}$ Once all states reach full incorporation, obedience - not merely compliance-will be achieved. Although they do not eschew enforcement measures, TLP theorists concentrate upon tasking institutions, and the epistemic communities captaining them, with diffusing the normative content of international legal regimes and urging relevant constituencies to accede to further measures of internalization. ${ }^{137}$ Although TLP has paid little mind to the question of IHL compliance, the theory presumes that compliance should be greatest for those states that have (1) ratified the greatest number of IHL instruments and expressed the most unqualified support for customary obligations and (2) passed the most comprehensive domestic implementing legislation incorporating treaty-based and customary obligations in their civil and military

\footnotetext{
${ }^{132}$ See Guzman, supra note 4, at 1825 (stating that reputational effects likely exist only "when the stakes are relatively modest" and suggesting that "many of the topics that receive the most attention in international law[,]" such as IHL, "are unlikely to be affected by international law.").

${ }^{133}$ See SHELTON, supra note 29, at 52-53 (presenting the TLP assumption that cooperation merely requires that states be encouraged to "indulge their initial inclinations" toward cooperation).

${ }^{134}$ See Harold Koh, Transnational Legal Process, 75 NEB. L. REV. 181, 183-84, 204 (1996) ("It is through this repeated process of interaction and internalization that international law acquires its 'stickiness' . . and that nations define promoting the rule of international law as part of their national self-interest.").

${ }^{135}$ Hathaway, supra note 12, at 1961 (describing internalization of international norms and rules in domestic law, a process carried out primarily by foreign policy personnel but also through executive orders, legislation, and judicial decisions, as central to evolution of cooperation). TLP theorists recognize that states will vary in the degree to which they internalize international law, but maintain that "every sizable government operates according to rules" and that invariably states will incorporate international legal obligations and thereby "produc[e] respect for standing rules of international law[.]" FISHER, supra note 26, at 147.

${ }_{136}^{136}$ Raustiala \& Slaughter, supra note 8, at 544.

${ }^{137}$ See generally Harold Hongjuh Koh, How is International Human Rights Law Enforced?, 74 IND. L.J. 1397 (1998) (urging a holistic approach, centered upon domestic incorporation, to the project of enhancing compliance).
} 
laws. TLP might further predict that membership in international institutions created to monitor compliance and adjudicate disputes and violations will correlate with increased compliance. add note

\section{Normativism}

Normativism is the cluster of pretheories concerned with the influence of morality and justice ${ }^{138}$ and committed to several primary principles: (1) sources of non-legal obligation exert theoretically significant causal effects on individual and state behaviors that are not reducible to rational or utilitarian calculations of material costs and benefits; ${ }^{139}$ (2) even in a world without "law," individuals and states would engage in norm-governed behaviors; ${ }^{140}$ (3) states will accept legal obligations not solely to advance material self-interests but to further normative conduct; ${ }^{141}$ (4) individuals and states are motivated to obey obligations even when compliance runs counter to material self-interests; ${ }^{142}$ and (5) state compliance with international law reflects, to some measurable degree, commitments to norms. Normativism consists of three distinct but interrelated theories each of which treats norms ${ }^{143}$ as vital to compliance: legitimacy theory, organizational theory, and constructivism.

\section{a. Legitimacy Theory}

Legitimacy theory ["LT"] posits that the more legitimate a regime, the more likely states will be to afford it compliance. In turn, LT defines legitimacy as "a property of a rule . . which itself exerts a pull toward compliance ... because those addressed believe that the rule or institution has come into being and operates in accordance with generally accepted principles of right process[.]"144 LT describes

\footnotetext{
add note See, e.g., Johanna van Sambeek \& Mireille Hector, Disseminating of IHL at the Domestic Level, in MAKING THE VOICE OF HUMANITY HEARD (L. Lijnzaad, J. van Sambeek, \& B. Tahzib-Lie, eds. 2004), at 384-97 (linking dissemination of knowledge of IHL within domestic societies with enhanced compliance).

${ }^{138}$ See TOM R. TYLER, WHY PEOPLE OBEY THE LAW 3 (1990).

${ }^{139}$ See MARTHA FINNEMORE, DEFINING NATIONAL INTERESTS IN INTERNATIONAL SOCIETY 87 (1996) ("[P]rincipled concerns, morality, and individual action" are as important to understanding the motivation of individuals and states are"rational" considerations); FISHER, supra note 26, at 143 (identifying religious beliefs, "family, schools, [and] cultural attitudes" regarding justice as primary determinants of interests and behaviors in normative accounts of legal compliance); TYLER, supra note 139, at 23 (holding that "other bases for securing compliance with law: social relations (friends, family, peers) and normative values" exceed the importance of formal legal rules); id. at 21 ("Citizens have been found to obey the law when the probability of punishment for noncompliance is almost nil and to break laws in cases involving substantial risks. Neither form of behavior makes sense from a strictly instrumental perspective."). Simply put, for normativist theoreticians norms have a "grip on the mind." JOHN ELSTER, THE CEMENT OF SOCIETY 100 (1989).

${ }^{140}$ See POSNER, supra note 80 , at 3 ("In a world with no law and rudimentary government, order of some sort would exist ... The order would appear as routine compliance with social norms and the collective infliction of sanctions on those who violate them[.]"); FRIEDERICH W. KRATOCHWIL, RULES, NORMS, AND DECISIONS (1989) (stressing importance of non-legal norms in international relations); ELLICKSON, supra note 118 (same).

${ }^{141}$ See, e.g., Ann Florini, The Evolution of International Norms, 40 INT'L STUD. Q. 363, 367 (1996).

${ }^{142}$ See Martii Koskenniemi, The Pull of the Mainstrean88 MICH. L. REV. 1946 (1990) (theorizing that non -legal sources of normative prescription regarding "what is right and good for human life" that precede attempts at positive legal regulation are more effective in securing compliance with behavioral objectives); YOUNG, supra note 10, at 23 (noting that "inner pressures" to comply with the law out of a sense of duty can overwhelm short-term seld interest in violating the law). In normativist accounts of individual behavior, norms are "part of [an] internal motive system and guide [individuals'] behavior even in the absence of external authority." M. Hoffman, Moral Internalization: Current Theory and Research, in ADVANCES IN EXPERIMENTAL SOCIAL PSYCHOLOGY (L. Nerkowitz ed., 1977). As Tyler explains, considerations of self-interest and the effectiveness of enforcement measures are subordinate in theoretical terms to the power of norms:

If people view compliance with the law as appropriate because of their attitudes about how they should behave, they will voluntarily assume the obligation to follow legal rules. They will feel personally committed to obeying the law, irrespective of whether they risk punishment for breaking the law.

TYLER, supra note 139, at 3.

${ }^{143}$ An operational definition describes norms as "standards of behavior defined in terms of rights and obligations" or as a "set of intersubjective understandings readily apparent to actors that makes behavioral claims on those actors" and "leave broad patterns of the sort that social science strives to explain." FINNEMORE, supra note 140, at 2 n.2 (1996). Put more simply, norms provide answers to the question of what "ought" to be, rather than solely to what is.

${ }^{144}$ THOMAS M. FRANCK, FAIRNESS IN INTERNATIONAL LAW AND INSTITUTIONS 24 (1995). Legitimacy, expressed thusly, is distinct from morality inasmuch as commitment to obey law on moral grounds implies that the substantive content of 
the primary determinants of legitimacy as (1) the clarity or transparency of the legal rules and the norms they reflect; ${ }^{145}$ (2) the symbolic importance of the rules; (3) the "coherence" of the regime, defined as the degree to which rules are connected to principles of reason; ${ }^{146}$ and (4) adherence to the regime, defined as the connection between its primary and secondary rules. ${ }^{147}$ Although some LT theorists suggest that compliance is more multivariate, hinging in part on the likelihood that violations will be detected and punished and in part on the views of relevant peer groups, ${ }^{148} \mathrm{LT}$ invariably regards compliance as a function of legitimacy: those regimes widely perceived to be created and administered fairly are entitled to, and do in fact reap, compliance. ${ }^{149}$

Specifying LT still further, if compliance is a function of legitimacy, LT theory predicts that the degree to which any particular state complies with international law is in turn a function of the degree to which that state deems international law generally, or the particular regime in question specifically, to have been derived through fair procedures. LT theory assesses whether the rules in question are perceived to be substantively just-i.e., connected to principles of reason, justice, morality, or other first principles ${ }^{150}$-as justice is a necessary precondition for compliance. Finally, if legitimacy is held constant as between two alternative sets of rules, LT theory predicts that compliance will be greatest with that regime that expresses the most moral content. ${ }^{151}$

Thus, in regard to IHL, a regime consisting of numerous instruments to which essentially all states are parties and constituting what are arguably a series of obligations erga omnes, LT would predict that most states should perceive it as legitimate and that compliance should be high, ${ }^{152}$ particularly for those states for whom the primary rules are reasonable and the procedures for resolving disputes about the

the law is perceived as inherently just, whereas a commitment to compliance on the ground that the regime is legitimate, while it need not exclude moral considerations, rest upon the narrower procedural conclusion that "the authority enforcing the law has the right to dictate behavior." TYLER, supra note 139, at 3 (differentiating morality and legitimacy).

${ }_{145}$ See SHELTON, supra note 29, at 4. An important premise of LT theory is that the greater the determinacy of a legal rule the more normative weight it is presumed to carry and the more compliance it will secure. See, e.g., JAN KLABBERS, THE CONCEPT OF TREATY IN INTERNATIONAL LAW 24 (1996).

${ }^{146}$ See FISHER, supra note 26, at 105 ("[F]rom the point of view of a government, ... [t] $]$ he incentive to break a rule of international law or to respect it depends overwhelmingly upon the particular subject of the rule ... A rule draws strength in proportion to the extent to which it makes sense to whom it applies."); Mark W. Zacher, The Territorial Integrity Norm: International Boundaries and the Use of Force, 55 INT'L ORG. 215 (2001) (linking compliance with law to the degree to which "the norms it embodies are widely shared by its subjects.").

${ }^{147}$ FRANCK, supra note 145 , at 24.

${ }^{148}$ See Keohane, supra note 77, at 491-93 (describing the "normative optic" of international law and international relations, a manner of understanding that grounds the legitimacy of international regimes in norms). Although moral considerations are not banished from LT, the theoretical significance of legitimacy, defined as procedural fairness, is regarded as greater than that of moral considerations, which are rooted more in substantive justice: an advantage of privileging legitimacy over morality in securing compliance is that

when the law is viewed as legitimate people feel that they "ought to obey" all laws, not just those that are consistent with their own moral principles. Hence, legitimacy is a more widespread, "blanket" endorsement of law's value than morality. If authorities are legitimate, people are generally willing to accept the rules they create, whatever those rules might be.

TYLER, supra note 139 , at 3.

${ }^{149}$ See id. at 31 (analyzing studies demonstrating strong correlation between perceptions of legitimacy of legal systems and individual compliance); Kingsbury, supra note 79, at 355 (referencing studies linking compliance with legal rules to the perception that the rules are fair); FRANCK, supra note 145, at (theorizing that normative legal regimes are formed and perpetuated by transnational actors through series of socially derived procedures, and provided those procedures are widely perceived as fair, states tend to subordinate self-interest in favor of compliance).

${ }^{150}$ See Williamson, supra note 20, at 74-77 (predicting compliance as a function of the degree of acceptance of the moral or substantive content of the norm within the domestic polity of the relevant state).

${ }^{151}$ FISHER, supra note 26, at 111 ("Other things being equal, the more elemental the rules are, the more inherent moral content there is and hence more . . compliance . . can be expected.”). 
rules are fair. Compliance failures, in turn, are attributable not to any failure to capture important normative principles but to failures of treaty drafters to specify clear primary rules, ${ }^{153}$ to the perceived unreasonableness of particular rules, or, most importantly, to perceptions of unfairness in the adjudication of disputes. Finally, as understandings of the meanings of rules converge through practice, LT predicts that the legitimacy of, and compliance with, IHL should increase incrementally. ${ }^{154}$ To some degree, LT theory considers compliance with law to be a cultural preference promotable through fair procedural practice.

\section{b. Constructivism}

In addition to the central premises of normative theories - that states are motivated by non-legal sources of obligation and that states will comply with international law even when to do so conflict with their material self-interest—constructivism posits the following: (1) states are not simply material creatures with pre-established preferences but are in fact ideational entities continuously reconstituted by the socially-generated values, morals, and ideas of the individuals and groups who form and direct them $;{ }^{155}(2)$ normative scripts of key individuals and groups are principally responsible for constructing states and investing them with preferences; (3) the constructive process is reciprocal and dynamic: the normative structure of the state is instilled in those who participate in its formation and direction; ${ }^{156}$ (4) politics is constructed at domestic and transnational levels, and preferences are flexible: individuals and groups in one state, through patterns of "persuasion, socialization, and pressure[,]" influence the normative perceptions and political agendae of their counterparts in other states; ${ }^{157}$ at the same time, state preferences are not immutable, and states actively and passively urge other states to reconstruct themselves and adopt their normative prescriptions; ${ }^{158}$ (5) legal rules qua rules do not independently generate compliance pull: laws are, in effect, "restate[ments] [of] social values and norms[,]"159 and individuals and states conform their conduct not to the formal content of rules but to a set of internalized norms that may or may not be reflected in formal legal regimes; ${ }^{160}$ and (6) to a large extent, compliance is a function of the congruence between operative norms and legal rules.

\footnotetext{
${ }^{152}$ See FOX \& MEYER, supra note 37, at 21 (describing IHL as a "series of unilateral engagements solemnly contracted before the world ... which create obligations erga omnes . . . : they are moral, not merely legal obligations.").

${ }^{153}$ See BUTLER, supra note 23, at 195 (describing attacks on merchant vessels during the Gulf War as the result of uncertainty over the substantive content of legal obligations to neutrals).

${ }^{154}$ CHRIS GELPI, THE POWER OF LEGITIMACY: ASSESSING THE ROLE OF NORMS IN CRISIS BARGAINING 5 (2003).

${ }^{155}$ See Alexander Wendt, Collective Identity Formation and the International State, 88 AM. POL. SCI. REV. 384, 384-85 (1994) (describing the role of norms in "constructing" the state).

${ }^{156}$ See generally PETER J. KATZENSTEIN, ED., THE CULTURE OF NATIONAL SECURITY: NORMS AND IDENTITY IN WORLD POLITICS (1996).

${ }^{157}$ See MARGARET F. KECK \& KATHRYN SIKKINK, ACTIVISTS BEYOND BORDERS 214 (1998) (discussing the reciprocal transnational effects of norm entrepreneurship and progressive discourses); see also FINNEMORE, supra note 140, at 5-6 (arguing that NGOs transform state behaviors "not by constraining states with a given set of preferences from acting, but by changing their preferences.").

${ }^{158}$ See, e.g., John Gerard Ruggie, What Makes the World Hang Together? Neo-Utilitarianism and the Social Constructivist Challenge, 52 INT'L ORG. 855, 878-82 (1998).

${ }^{159}$ E. Lutz \& K. Sikkink, International Human Rights Law and Practice in Latin America, 54 INT'L ORG. 633, 656 (2000).

${ }^{160}$ See generally H.L.A. HART, THE CONCEPT OF LAW $\left(2^{\text {nd }}\right.$ ed. 1994) (stressing that compliance requires an internal attitudinal commitment that in turn requires that the formal rules be consistent with normative values); Raustiala $\&$ Slaughter, supra note 66, at 504 (summarizing the constructivist argument that compliance requires that law comport with "internalized identities and norms of appropriate behavior").
} 
Constructivism has left the terrain of IHL largely untilled. Nonetheless, explanations and predictions of IHL compliance would seem to require, for constructivists, determinations of the extent to which the norms animating particular conventional and customary sources correspond with the preferences of key states and individuals as well as the extent to which those norms are faithfully reflected in formal rules of law. Constructivism is vitally concerned with "who we are and what we want to become as a nation[,]"161 and provided states and key individuals have been "constructed" by, or conditioned to adhere to, a norm proscribing a method of warfare-i.e., assassination—and provided rules of law correspond to and tap into the normative prohibition, constructivism would predict that states would eschew the practice even if it is a substantively rational battle strategy. ${ }^{162}$ For constructivists, therefore, building a culture of IHL compliance requires a joint program of norm inculcation and legal engineering.

\section{c. Organizational-Cultural Theory}

Organizational-cultural theory ["OCT"], a cluster of theories that disaggregate states and treat government bureaucracies, rather than states themselves, as the primary level of analysis of theoretical interest, ${ }^{163}$ has evolved from the presumption that bureaucracies are rational actors ${ }^{164}$ to more sophisticated models that account for state decisions through the analysis of the specific and idiosyncratic organizational culture ${ }^{165}$ in which relevant foreign policy behaviors are debated and advocated. OCT posits that a common core of beliefs, values, and philosophies arises over time and specifies a code that dictates how a social group reacts to external stimuli and organizes its internal affairs; norms, rather than interests, drive the development of this organizational culture. ${ }^{166}$ In turn, each member is socialized through participation in his nomos ${ }^{167}$ and thus comes to internalize and espouse this culture and to conform his conduct to the expectations of the group. ${ }^{168}$ At the same time, the organizational cultures of certain social groups exert transformative influences upon other social groups and key individuals who

\footnotetext{
${ }^{161}$ Seymour M. Hersh, Manhunt, NEW YORKER, Dec. 23, 2002, at 73.

${ }^{162}$ See Michael N. Schmitt, State Sponsored Assassination in International and Domestic Law, 17 YALE L. J. INT'L L. 609, 631-32 (1992) (making a constructivist argument that a global norm precludes or slows recourse to assassination even when political killing might serve vital security interests and maximize national welfare).

${ }^{163}$ See M.A. EAST, WHY NATIONS ACT 28-29 (1987) (tracing theoretical evolution in the study of international relations from the static level of analysis to the level of the governmental regime and the foreign policy bureaucracies).

${ }^{164}$ See, e.g., GRAHAM ALLISON, ESSENCE OF DECISION (1971) (elaborating an organizational theory of state behavior grounded in rational choice theory).

${ }^{165}$ See LEGRO, supra note 55, at 4 (defining "organizational culture" as the hierarchy of beliefs that characterize the formal institutional structure of a given social group, profession, organization, or bureaucracy).

${ }^{166} I d$. at 19-20 ("What may seem completely irrational to an outsider may make perfect sense to those within a certain community ... Buddhist monks setting themselves on fire or World War II Japanese pilots carrying out massive kamikaze attacks are difficult to understand unless seen through the lens of the particular cultural milieu in which those actions originated."). For a more general discussion of OCT, pitched as "global governance" theory and committed to the notion that networks of global governance, including bureaucracies, courts, regulatory agencies, and legislatures, are crucial to the evolution of normative legal architecture, see ANNE-MARIE SLAUGHTER, A NEW WORLD ORDER (2004).

${ }^{167}$ See Robert M. Cover, The Supreme Court, 1982-Foreword: Nomos and Narrative, 97 HARV. L. REV. 4 (1983) (defining "nomos" as a "community of like-minded individuals sharing a way of life" and a "world view").

${ }^{168}$ See LEGRO, supra note 55, at 23 (explaining that OCT "predict[s] that [behavior] will reflect and reaffirm [the] internal beliefs and customs" of the social group). When members of social groups fail to behave in accordance with the expectations of the organizational cultures of their groups, the groups "reward and punish their members, either by withholding or conferring signs of group status and respect[.]"). TYLER, supra note 139, at 23. The pro-social normative pressure exerted by social groups is important in conforming behavior and is "similar to the influence of personal morality." Id.; see also ROBERT B. CIALDINI, INFLUENCE: THE NEW PSYCHOLOGY OF MODERN PERSUASION (1984) (discussing the socialization of individuals into groups more generally).
} 
hold positions of authority both within states ${ }^{169}$ and across state boundaries via networks of professionals that form transnational epistemic communities around the nuclei of their domestic organizational cultures. ${ }^{170}$ Ultimately, OCT maintains that state preferences are neither predetermined nor dictated by rules but are created and shaped by the organizational cultures of those groups most salient to the issuearea of international relations in question, and that state compliance choices are mediated and shaped by these organizational cultures. ${ }^{171}$

The armed forces of states monopolize the capacity to use force and possess virtually all the available military expertise. Consequently, although civilian decisionmakers possess ultimate decisional authority in most states, national military bureaucracies ["NMBs"] are extremely influential social groups in respect to warfighting. Organizational-cultural variables define the preferences of NMBs and "shap[e] how soldiers th[ink] about themselves, perceiv[e] the world, formulat[e] plans, advis[e] leaders, and [go] into action." ${ }^{, 12}$ Although early OCT theorists predicted NMBs would invariably seek to maximize their autonomy and thus advocate to civilian decisionmakers conflict over peace and the use of all battle strategies over restraint, ${ }^{173}$ empirical data ${ }^{174}$ undermines this presumption and suggests to the contrary that NMBs routinely reject battle strategies that would directly contribute to victory for reasons rooted in organizational norms. ${ }^{175}$ In part this reciprocal restraint may be attributable to the disproportionate risk that decisions resulting in war or escalating the intensity of conflict impose upon the military caste relative to all other citizens: ${ }^{176}$ indeed, "the soldier above all prays for peace, for it is the soldier who must suffer and bear the deepest scars of war." ${ }^{177}$ Even more important, however, is the fidelity that NMBs owe to the chivalric code that prescribes how, where, and when force may be used to subdue enemies and what methods and means may be employed to do so.

Since ancient times, certain acts committed during war, including the deliberate murder of civilians and the perfidious have been widely known to be "manifestly wrongful, on account of their flagrant inconsistency ... with [the] professional character as an honorable [soldier.]" code of chivalry, which developed a detailed set of principles for the violation of which knighthood could

\footnotetext{
${ }^{169}$ LEGRO, supra note 55, at 17

${ }^{170}$ See Peter M. Haas, Introduction: Epistemic Communities and International Policy Coordination, 46 INT'L ORG. 1, 3,27 (1992) (describing the process of transnational diffusion of the normative codes of "network[s] of professionals with recognized expertise and competence in a particular domain" who function as "channels through which new ideas circulate from societies to governments as well as from country to country.").

${ }^{171}$ Kingsbury, supra note 79, at 362-63. OCT theory stresses that states are shaped by the organizational cultures of relevant social groups even as they exert reciprocal influence upon these groups. See LEGRO, supra note 55, at 5 ("In formulating strategy, states must understand and influence, not only the opponent and the environment, but also the idiosyncratic beliefs of their internal stategy-making community.").

${ }^{172} I d$. at 2 .

${ }^{173}$ Id. at $17-18$ (examining early theories).

${ }^{174}$ The military organizational culture of a state is surveyed and measured by reviewing internal correspondence between civilian decisionmakers and senior military officers, military planning documents, manuals of military law and field regulations, and memoirs of key individual civilian decisionmakers and military personnel. See, e.g., id. at 30.

${ }^{175}$ See id. at 41-128 (explaining refusals of World War II belligerents to use unrestricted submarine warfare or chemical weapons and variance between decisions as to strategic bombing as grounded in the operative norms of of relevant NMBs).

${ }^{176}$ See Richard A. Posner, Some Economics of International Law: Comment on Conference Papers, 31 J. LEG. STUD. 321,326 (2002) ("Military professionals have an interest in limiting the violence and savagery of warfare, because until the advent of bombing, and even since, they bear a disproportionate risk of becoming prisoners or casualties."). For a more general discussion of the principle of reciprocity in enforcing the behavioral norms of social groups, see GEORGE DALTON, TIRBAL AND PEASANT ECONOMIES 61-80 (1967).

${ }^{177}$ General Douglas MacArthur.

${ }^{178}$ MARK OSIEL, OBEYING ORDERS 207 (1999).
} 
be stripped, further developed this martial code. ${ }^{179}$ Knights engaged in a casuistic process of selfreflection and-criticism to determine whether particular acts breached this martial code. ${ }^{180}$ By the Renaissance a set of norms, internalized by a transnational professional caste requiring, inter alia, minimization of civilian casualties consistent with military objectives as a matter of honor, ${ }^{181}$ had perfused warfare. ${ }^{182}$ Further, the martial code, by rejecting the inhumanity of the enemy in favor of a conception of the foe as a fellow professional, directed the honorable soldier to renounce treachery and criminality in combating him, ${ }^{183}$ even if these tactics could be otherwise construed as rational. As the martial code diffused and matured, a collective narrative developed to inform soldiers in the discharge of their duties; when in doubt, soldiers conformed to "stories about the great deeds of honorable soldiers" drawn from the "collective narrative of [their] corps." ${ }^{184}$ In short, as a constituent aspect of their professional honor, soldiers are conditioned to accept risks by renouncing certain battle strategies, ${ }^{185}$ and it is this self-imposed commitment, undertaken as the price of membership in a global epistemic community, ${ }^{186}$ that upholds a common sociality and inspires adherence to the norms underlying IHL. ${ }^{187}$ Although variance exists across the range of NMBs, the chivalric code is a universal culture. ${ }^{188}$

For OCT then, predicting IHL compliance is a matter of determining the isomorphism between the formal rules of the legal regime and the behavioral dictates of the chivalric code: compliance correlates with congruence. NMBs may well resist the use of lawful battle strategies and advocate unlawful strategies for reasons having little to do with IHL and everything to do with their organizational

\footnotetext{
${ }^{179}$ See MAURICE KEEN, NOBLES, KNIGHTS, AND MEN-AT-ARMS 51-59 (describing chivalric virtue as graciousness to vanquished foes in recognition of shared membership in an international brotherhood-at-arms).

${ }^{180}$ OSIEL, supra note 179 , at 17.

${ }^{181}$ The concept of "honor" is now considered largely an anachronism in civil society but was once a "central construct in sociopolitical thought and a commonplace in works of law and political philosophy." Allen Z. Hertz, Honour's Role in the International States' System, 31 DEN. J. INT'L L. \& POL'Y 113, 114 (2002). Although definitions abound, most converge around the idea that honor signifies the "esteem, glory, or reverence that a man receives from his fellow men[.]" ALEXIS DE TOCQUEVILLE, 2 DEMOCRACY IN AMERICA 230 n.1 (Phillips Bradley ed., H. Rowe trans. 1953).

${ }^{182}$ See OSIEL, supra note 179, at 31-32 (“[[Soldiers] ask themselves: 'What is required of honorable soldiers, here and now?' rather than 'What does international law require[?]" . . Martial honor 'means doing nothing to tarnish that proud heritage' of one's unit, regiment, or branch of service[.]"). Under the martial code, a soldier gauges his conduct by asking not whether it was legal but rather "[w]ould [my] actions pass muster if . . . evaluated by responsible, respectable soldiers of yesterday and today?"). James H. Toner, Teaching Military Ethics 151 MIL. L. REV. 33, 37 (1993).

${ }^{183}$ In essence, the martial code fosters empathy for fellow martial professionals. Dianne Guillemette, Legal Advisers in Armed Forces, in F. Kalshoven, Implementation of International Humanitarian Law 133, 144 (1989).

${ }^{184}$ OSIEL, supra note 179 , at 21 . This narrative identity is conferred largely by anecdotal reference to an accreting stock of stories that detail how heroic soldiers behaved in combat. Id. (citing, as exemplary of such stories, Dept. of the Army, Values: A Handbook for Soldiers, sec. 2, Pamphlet 600 (Jan. 1987)).

${ }^{185}$ See Statement of General Douglas MacArthur in Confirming the Death Dentence Imposed by a United States Military Commission on Japanese General Tomayuki Yamashita for Command Responsibility in the Murder of U.S. POWs, October 1946 ("The soldier, be he friend or foe, is charged with the protection of the weak and unarmed. It is the very essence and reason for his being. When he violates this sacred trust, he no only profanes his entire cult but threatens the very fabric of international society. The traditions of fighting men are long and honorable. They are based upon the noblest of human traits-sacrifice."); see also FISHER, supra note 26, at 92 ("[S]oldiers are brought up to risk almost certain death rather than fail in their duty ... . even though there is no compensating chance of personal gain."); Prosecutor v. Erdemovic, Case No. IT-96-22 A, 7 October 1997, at para. 84 (holding that, by virtue of their special protective role, soldiers "are expected to exercise fortitude and a greater degree of resistance to a threat than civilians" and "by the very nature of their occupation . . . envisag[e] the possibility of violent death in pursuance of the cause for which they fight.").

${ }^{186}$ See Haas, supra note 171, at 1 (defining "epistemic community" as a "network of professionals with recongized expertise and competence in a particular domain and an authoritative claim to policy-relevant knowledge within that domain" as well as to a set of shared norms and practices to guide self-regulation); Goodman \& Jinks, supra note 55, at 1783 (describing NMBs as a global epistemic community that adheres to prescriptive norms of conduct).

${ }^{187}$ See RICHARD HARTIGAN, LIEBER'S CODE AND THE LAW OF WAR 5 (1983) (suggesting restraint in combat “d(oes) not stem from conscious articulation of principles of [IHL] so much as from a soldier's honor[.]").

${ }^{188}$ See LEGRO, supra note 55, at 27, 149 (noting that although the code of chivalry is universal, the degree of concordance between the organizational cultures of NMBs and the chivalric code varies across the universe of states).
} 
cultures. ${ }^{189}$ OCT predicts that there are some battle strategies, such as the use of chemical weapons, that are universally rejected by a transnational consensus of NMBs. ${ }^{190}$ However, where the organizational culture of the NMB of the state in question is sufficiently deviant from the universal norms that inhere in the chivalric code, ${ }^{191}$ OCT directs investigators to treat this normative structure as significant in determining the range of battle strategies the NMB will advocate to civilian decisionmakers and to incorporate this variable in deriving compliance predictions.

\section{B. Criticisms of Existing Pretheories}

\section{Realism}

The realist assumptions that systemic variables alone are sufficient to explain state behavior, and that states pursue material self-interest, measured in power, to the exclusion of all other ends, are readily falsifiable. States generally employ the least costly options that will secure their objectives, and cooperation is frequently preferable to unilateralist approaches. Moreover, state policies change over time even in the absence of transformations in the systemic distribution of political and military capabilities, and consequently something other than power must have causal influence upon state preferences. ${ }^{192}$ Furthermore, not all states are as committed to power, or as agnostic with regard to the importance of norms, as realists would have us believe, and realism simply lacks any explanation for how states come by their preferences. ${ }^{193}$ Thus, unless international law boosts state power, realism cannot explain why states enter into treaties, particularly those that inhibit the accumulation and deployment of power as do IHL instruments, let alone pay them any heed during the clash of arms.

\section{ET}

Enforcement of law requires will and capacity, and many states are unwilling to muster either or both. Evidence that the threat of punishment is often insufficient to deter noncompliance by powerful states whose military capacity largely immunizes their foreign policy decisions, ${ }^{194}$ as well as evidence that law-governed behavior can flourish even where no credible sanction can be imposed, ${ }^{195}$ leaves ET vulnerable to criticism as only slightly less ontologically primitive than realism.

\footnotetext{
${ }^{189}$ See, e.g., Goodman \& Jinks, supra note 55, at 1772 (noting that the U.S. policy of assassinating suspected terrorist leadership is lawful but has been opposed by senior members of the U.S. military bureaucracy on normative grounds).

${ }^{190}$ OCT theorists attribute a strong transnational aversion to the use of chemical weapons by NMBs to the widely-diffused view that chemical weapons are dishonorable, in that they kill indiscriminately and are largely indefensible, and foreign, inasmuch as their development and, to some extent, deployment is controlled by civilian scientists. See LEGRO, supra note 55, at 150 (summarizing this conclusion); see also Goodman and Jinks, supra note 55, at 1776 (stating that "[i]t has arguably become an unconditional feature of the modern state to forbear use of specific types of weapons[,]" such as chemical weapons, due to the overpowering influence of an opposed transnational military organizational culture).

${ }^{191}$ Explanations for deviance include national level variables (the political culture of the state) or governmental unit variables (group-level norms that motivate key decisionmakers) that are inconsistent with the chivalric code. In other words, the normative structure of the state or decisional unit affects the organizational culture and state decisions.

${ }^{192}$ See, e.g., ERIC SINGER \& VALERIE HUDSON, ED., POLITICAL PSYCHOLOGY AND FOREIGN POLICY 24 (1992) ("One of the most central criticisms of [realism] has been [its] inability to cope with change in a state's policies.").

${ }^{193}$ See DAVID EASTON, THE POLITICAL SYSTEM: AN INQUIRY INTO THE STATE OF POLITICAL SCIENCE (1953) (insisting that all theories of international relations, including realism must account for the formation of state preferences).

${ }^{194}$ See FISHER, supra note 26, at 92 ("[O]f all the factors affecting President Kennedy and his advisers during the October 1962 Cuban missile crisis, fear of possible punishment before a future Nuremburg Tribunal for having violated international law was not considered and, had it been raised, would have been dismissed out of hand."). States battling for their national survival are liberated from the threat of enforcement action: if they adhere to legal obligations but fail to survive, the question of enforcement is moot; if they violate the law and in so doing survive, whatever costs are imposed through enforcement measures are more than offset by the gains achieved through violation.

${ }^{195}$ See YOUNG, supra note 10, at 18 ("Even when there are no public authorities and social pressures are absent, ... compliance will sometimes emerge as a preferred option[.]").
} 


\section{Liberalism}

The conclusion that liberal democratic states are more likely to comply with IHL than illiberal states is exceedingly difficult to prove, in part because the designation of particular states as liberal or illiberal is a subjective enterprise in which selection effects bias outcomes, ${ }^{196}$ and in part because most empirical studies have examined correlations between government regime type and war participation frequency, rather than IHL compliance. ${ }^{197}$ Athough some scholars suggest that liberal states are more likely than illiberal states to accede to legal regimes, others question whether their willingness to do so is motivated by a desire to abide by their normative content as opposed to an interest in "satisfying the public face of international law" and appeasing domestic constituencies while surreptitiously carrying on as usual. ${ }^{198}$ Others query whether democratic states, because they are more tolerant of the proliferation of interest groups than illiberal states, are more prone to contestation over the process of incorporating legal obligations into the domestic framework and thus less likely to comply with legal regimes that, by virtue of their imprecision or ambiguity, are more vulnerable to self-serving interpretations. ${ }^{199}$ Still others note that even illiberal states comply with many of their obligations, including those to which they have acceded in issue-areas trenching in high politics, such as the use of force. ${ }^{200}$ Finally, liberalist scholars offer little to explain the microprocesses whereby the preferences of domestic groups and individuals transform the preferences of states in favor of IHL compliance. ${ }^{201}$

\section{RCT}

Although RCT presents a parsimonious explanation for state compliance with IHL, if the central postulate upon which it rests - that individuals are rational and equally endowed with fixed preferences for welfare maximization - is falsifiable or, at least, subject to conditions and limitations, its generalizability is suspect. ${ }^{202}$ Although nearly all decisionmakers will flee a burning house, they are differentiable even in regard to their responses to stark existential threats, and in respect to lesser-order challenges preferences vary tremendously in response to a host of non-material inputs, including social norms, emotions, cultural practices, and the need for identity, security, recognition, self-esteem, and justice. ${ }^{203}$ The world is home not only to homo economicus but to idiosyncratics, ideologues, fools,

\footnotetext{
${ }^{196}$ See Toril Aalberg, Democracy and Peace: A More Skeptical View, 33 J. PEACE RES. 1 (1996) (noting that the taxonomy of states into liberal and illiberal categories requires numerous subjective judgments and is fraught with selection bias).

${ }^{197}$ See, e.g., Nils Petter Gleditsch, Democracy and Peace, 29 J. PEACE RES. 369 (1992) (finding that war participation rates do not vary as between democracies and non-democracies); BRUCE RUSSETT, GRASPING THE DEMOCRATIC PEACE (1994) (recognizing that "democratic peace" theory has ignored the question of IHL compliance)

${ }^{198}$ See, e.g., Jacqueline Alder \& Gaul Lugten, Frozen Fish Block: How Committed are North Atlantic States to Accountability, Conservation and Management of Fisheries?, 26 MARINE POL'Y 345, 356 (2002); Hathaway, supra note 12, at 2016 (suggesting that for some states, treaty ratification allows a state to express insincere support for treaty norms while diffusing domestic and international pressure to actually comply. Some even suggest that, because accession often associates with reductions in compliance, and because liberal states are more likely to accede to treaties than illiberal states, a negative association exists between liberalism and compliance. See, e.g., Moore, supra note 34, at 881.

${ }^{199}$ See, e.g., Ho, supra note 24, at 663-83.

${ }^{200}$ See Williamson, supra note 20, at 81 (indicating that many illiberal states, including "dictatorships," comply with legal obligations under arms control and security agreements).

${ }^{201}$ For a constructivist critique of the inability of liberalism to account for the process whereby liberal states acquire and adapt their preferences, see KECK \& KSIKKINK, supra note 158, at 214.

${ }^{202}$ See Thomas Ulen, Rational Choice in Law and Economics, in Boudewijn Boukert \& Geerit de Geest, eds., Encyclopedia of Law and Economics 790 (Edward Elgar 2000) (contending that this core assumption of RCT is indeed falsifiable).

${ }^{203}$ See generally JOHN W. BURTON, CONFLICT: HUMAN NEEDS THEORY (1990). For a critique of RCT as a reductionist approach, see William H. Riker, The Political Psychology of Rational Choice Theory, 16 POL. PSCYH. 23 (1995); MARY ANN
} 
wishful and delusional thinkers, ${ }^{204}$ altruists, martyrs, and those who actively prefer violence and misery to wealth and comfort, ${ }^{205}$ and many nonrational persons wend their ways into command of states and key institutions. ${ }^{206}$ Decisionmaking pathologies produce substantial deviation from RCT predictions, i.e., the decision by Saddam Hussein to remain in Kuwait and await a U.S.-led invasion in 1991 or the Japanese attack on Pearl Harbor. Moreover, even if one accepts the RCT premise that individuals are selfinterested, the complexity and uncertainty that characterize many foreign policy decisional environments force decisionmakers who lack relevant information to adopt "short-cuts to rationality" that produce systematic and motivated errors in judgment at variance with RCT predictions. ${ }^{207}$ People make mistakes, and some critics of RCT would go so far as to reverse the presumption and require decisionmakers to "establis[h] that their ... decisions for war and peace are fully based on truly national and objective considerations, rather than expressing mere rationalizations of private emotional dispositions. ${ }^{208}$ In sum, RCT critics insist that because state preferences vary as a function of variance in the preferences of key decisionmakers, ${ }^{209}$ and therefore explanations of state compliance with IHL are reducible to explanations of the foundations of the preferences of key decisionmakers with regard to that regime. ${ }^{210}$

\section{Managerialism}

The assumption that states comply with law because well-articulated and -managed legal regimes facilitate their collective interest in cooperation is controvertible in the case of IHL, a legal regime directed to the conduct of states that have placed themselves in the least cooperative posture imaginable. MT, committed to the notion of states as inherently cooperative, cannot explain why states deliberately choose to reject the constraints imposed by IHL and employ prohibited battle strategies in order to prevail over their adversaries, and the MT response — enhancement of monitoring and verification—is particularly ill-suited to addressing deliberate noncompliance. States may simply be disinterested in cooperation during war no matter how clear the rules that purport to govern its conduct nor how welldeveloped the mechanisms designed to spread information and thereby cooperation. If so it may simply

TETREAULT \& CHARLES FREDERICK ABEL, DEPENDENCY THEORY AND THE RETURN OF HIGH POLITICS 1417 (1986) (arguing that foreign policy decisionmaking is "much less rational than we all pretend it is").

204 "Wishful thinking" is a motivated bias in which decisionmakers evaluate the probability of outcomes they prefer as more likely to occur, and the probability of outcomes they disfavor as less likely to occur, than rational analysis would suggest to be the case. See SEARS ET AL., supra note 78, at 268.

${ }^{205}$ See DONALD A. SYLVAN \& STEVE CHAN, EDS., FOREIGN POLICY DECISION MAKING: PERCEPTION, COGNITION, AND ARTIFICIAL INTELLIGENCE 2-3 (1984) (offering examples to reject the presumption of individual rationality).

${ }^{206}$ See KEOHANE, supra note 109, at 72 (warning that RCT cannot be "applied mechanically" to the study of international relations because there are "sinners and saints" in the world); see also David G. Winter, Personality and Political Behavior, in SEARS ET AL., supra note 78, at 110 (stressing that the "intrusion of personal appetites, needs, fears, and obsessions g[i]ve a quality-irrational, self-defeating, and/or violently aggressive-to many [foreign policy decisions.]").

${ }^{207}$ ROBERT M. JERVIS, PERCEPTION AND MISPERCEPTION 113 (1976). "Motivated errors" are judgments based not on objective evaluations of available evidence but on the basis of needs or desires. SEARS ET AL, supra note 78, at 267.

${ }^{208}$ LLOYD S. ETHEREDGE, A WORLD OF MEN: THE PRIVATE SOURCES OF AMERICAN FOREIGN POLICY 100 (1978). For many critics of RCT, “" "assumptions about the inherent rationality of humans rests upon little, if any, foundation." SINGER \& HUDSON, supra note 193, at 24.

${ }^{209}$ See Morrow, supra note 39, at 50 ("States vary greatly in their interest in supporting restrictions on violence during wartime.").

${ }^{210} \mathrm{Id}$. at 51 (attributing state decisions as to IHL compliance to the beliefs and moral judgments of their decisionmakers with respect to the substance of that regime). 
be the case that the policy guidance offered by MT is limited in its applicability to issue-areas in which states can enjoy material benefits from cooperative behavior, such as trade or environmental protection. ${ }^{211}$

\section{Reputational Theory}

RT has been challenged as limited in its theoretical reach to those issue-areas in which states value a reputation. Although a reputation for honesty, fairness, and cooperation is valuable in economic and diplomatic transactions because other states will refrain from dealing with states that do not possess such characteristics, in the issue-area of armed conflict such a reputation may actually be perceived as a weakness, and states may actually prefer a reputation "for toughness or even for being willing to bully weaker states, more than they value reputations for compliance." ${ }^{212}$ Critics of RT suggest that when the potential gains for violating law are great enough, particularly in comparison to the probable reputational costs that must be absorbed for pursuing self-interest, reputational concerns shrink to nothing. ${ }^{213}$ In regard to the use of force, where the stakes are greatest, even some RT scholars admit that reputation is all but irrelevant. $^{214}$

\section{TLP}

Nearly every state has incorporated all the primary instruments of IHL. If, as TLP contends, compliance is a function of the degree to which a given legal regime is internalized in domestic law, states should reflexively and uniformly obey IHL. Because practice contradicts this prediction, it is reasonable to question whether in fact the norms expressed in the rules elaborated by IHL instruments are internalized, and whether incorporation is necessarily, as TLP theorists believe, instructive in any meaningful sense as to how much legitimacy is to be imputed to the relevant norms. The principle shortcomings of TLP theory are that it fails to treat the process of norm incorporation as the proper subject of inquiry and that it leaves unexplored the mechanisms whereby norms change behavior or attitudes. As a consequence, TLP cannot offer insights into why and when states comply with IHL and is left simply presuming that they do notwithstanding evidence to the contrary.

\section{LT}

If LT is arguably more than simply the bare assertion that nations obey the law, it is not a testable theory. Mere observation of state compliance without an explanatory model is a descriptive, but not a nomothetic, statement of the relationship between law and behavior. LT builds no causal bridge between the norms of procedural fairness it identifies as essential to the legitimacy of international legal rules and

\footnotetext{
${ }^{211}$ See Downs et al, supra note 26, at 391 (reaching this conclusion); see also Raustiala, supra note 27, at 405-08 (criticizing MT as "dangerously contaminated by selection problems" for failing to draw cases from a range of issue-areas, including security and armed conflict, that would more appropriately represent the entire spectrum of international relations); Moore, supra note_, at 1832-33 ("As long as one is only interested in coordination games, [MT] provides a good guide for compliance and national behavior.").

${ }^{212}$ Keohane, supra note 77, at 497. Skeptics of RT note that legal commitments involving national security are qualitatively different from those in other issue-areas and are, in some sense, made to be broken: because all states are presumably prepared to do whatever necessary to ensure their physical survival, other states discount the reliability of commitments that would limit states in this regard, and consequently do not impose significant reputational costs for their violation. See, e.g., Richard Baxter, International Law in “Her Infinite Variety,” 29 INT’L \& COMP. L. Q. 551 (1980).

${ }^{213}$ See, e.g., Goldsmith \& Posner, supra note 86, at 1135-36.

${ }^{214}$ See Guzman, supra note 4, at 1883-84 (conceding that "[t]he value of a reputation for compliance with international commitments is rarely large enough to affect the outcome when decisions are of such magnitude."); id. at 1885 ("The most promising fields of study [for RT] . . . are those in which reputational effects are likely to affect behavior" such as environmental or economic issues, but the "great questions of war . . . and [peace]" are likely beyond its explanatory reach).
} 
their effects upon decisionmakers who must make compliance decisions, and as a consequence it is unable to elaborate any testable explanatory hypotheses. ${ }^{215}$

\section{Constructivism}

By offering slightly more insight into the pathways whereby norms alter preferences and give rise to formal legal regimes, constructivism does permit the generation of some testable hypotheses. However, just as is LT, constructivism is grossly underspecified: no account is offered for the process whereby norms are acculturated and linked with individual decisions, and constructivists simply offer a loose explanation that relies on the workings of international civil society as a sort of deus ex machina. ${ }^{216}$ What is worse, constructivism rests upon a contestable assumption regarding human and state nature. Constructivists tacitly assume that the norms that come to predominate in the construction of individual and state preferences will invariably motivate the transformation from power and self-interest toward greater transnational cooperation. Throughout human history, destructive ideologies and the lust for power have proven at least as susceptible of proliferation, and it is equally plausible that individual and state preferences strongly favoring the self-interested maximization of power may emerge, diffuse through the international system, and prove fatal to law-governed cooperation. ${ }^{217}$ Moreover, not all individuals are as amenable to construction as are others, and some actively resist normative socialization. ${ }^{218}$ Although the potential that individuals and states can be "constructed" by norms destructive of law and international civil society neither precludes compliance with IHL nor invalidates constructivism, it does demonstrate the need for additional theoretical articulation and substantiation.

\section{OCT}

OCT offers a coherent explanation for state compliance with rules of IHL that are congruent with the martial code, and predicts state compliance where both the martial code and IHL either prohibit the battle strategy in question (states will not employ the strategy) or permit it (states will employ the strategy). However, OCT cannot explain instances where NMBs refrain from battle strategies that, while prohibited by positive law, are clearly permissible under the martial code. If organizational culture is the independent variable, one would expect NMBs to discount the significance of IHL in favor of organizational preferences. Moreover, OCT theory cannot explain noncompliance with rules that mirror the commandments and injunctions of the martial code without incorporating levels of analysis exogenous to the NMB. Some individuals and groups may simply be resistant to socialization and thus impervious to the influence of organizational-cultural norms. Perhaps most significantly, OCT is unable to explain instances where NMBs refrain from employing battle strategies permissible under both the martial code and IHL without importing variables from levels of analysis that are conceptually distinct from organizational culture. In short, to explain and predict IHL compliance it is not enough simply to

\footnotetext{
${ }^{215}$ For a critique of LT, see Kingsbury, supra note 79, at 356-57.

${ }^{216}$ See Goodman \& Jinks, supra note 31, at 42 (examining this deficiency in constructivist theory).

${ }^{217}$ See Claire R. Kelly, Realist Theory and Real Constraints, 44 VA. J. INT'L L. 545, 635 (2004) (querying whether constructivists might in fact be destructive of legal norms and institutions).

${ }^{218}$ See LEROY N. RIESELBACH \& GEORGE I. BALCH, PSYCHOLOGY AND POLITICS 6 (1968) (describing the individual as a "distinct, autonomous person whose behavior, while influenced by the cultural and social situations in which he finds himself, will reflect the kind of individual he is .... [He] is by no means a helpless pawn, pushed and pulled by cultural and
} 
gauge the goodness of fit of the formal legal rules to the organizational culture the rules are meant to govern; rather, the causes and effects of organizational culture must themselves be problematized.

\section{Compliance Decisionmaking and the Inadequacy of Existing Theories}

Notwithstanding their individual merits, all existing theories are hobbled by structural biases that obscure human agency. Realists and adherents of ET and RCT characterize individuals as simply rational calculators of the relationship between state self-interests and compliance, while theorists of all other stripes treat them as, to greater or lesser degree, mere captives of rules embedded in regimes, institutions, and patterned cultural imperatives. Although subnational and supranational actors wax ever more important, the question of IHL compliance is ultimately directed to the question of responsibility for decisions, and neither the international system, nor states, nor domestic interest groups, nor bureaucracies have the capacity to elect compliance or noncompliance. ${ }^{219}$ The sole entities with the capacity to exercise choice are individuals, and only those individuals with the authority and power to commit the state are directly relevant to the study of compliance generally and IHL compliance in particular. ${ }^{220}$ People, and not abstractions such as organizations, cultures, interest groups, states, or systems, ${ }^{221}$ decide whether or not to comply with law, and even if individual preferences, attitudes, or values are derived from these entities these determinants of behavior constitute personality-based individual-level variables that may account for much of the systematic variance in compliance as between decisionmakers and, in turn, as between the states on behalf of which they decide. If so-if failures of compliance are often due to "indiscipline, ignorance, and cruelty",222 among other personality-based factors-a robust theory of human agency is essential to any explanation or prediction of state compliance with IHL.

This is not to suggest that other levels of analysis are theoretical blind alleys. The decision whether to comply with IHL is a question of foreign policy, and foreign policy is no more simply a question of personality than it is simply a question of power. The manner in which organizational machinery conditions and shapes individual preferences, as well as the political features of the government regime, the national and cultural attributes of the society in which the individual makes decisions, and the opportunities and constraints yielded and imposed by the distribution of power and resources in the international system all exert causal influences on individual decisions with regard to compliance with law, and each of these levels of analysis ${ }^{223}$ must be investigated, operationalized, and

\footnotetext{
social forces."); see also NEIL MACCORMICK, LEGAL REASONING AND LEGAL THEORY 284 (1978) (reminding that "any account of rules and norms and standards of conduct must . . . take account of those who operate with these norms.").

${ }^{219}$ See YOUNG, supra note 10, at 4 (insisting that all entities other than individuals behave in accordance "with the dictates of some genuine actor and need not be dealt with separately in any study of compliance.").

${ }^{220}$ See id. at 41 ("[The] special feature of the compliance problem of collective entities is the question of who is ultimately responsible for violations[,]" and "it is ultimately the actions of individuals which determine the external behavior of collective entities.").

${ }^{221}$ See JAMES N. ROSENAU, INTERNATIONAL POLITICS AND FOREIGN POLICY 88 (1961) (describing the state as an "abstraction from the pattern of behavior shown by persons.")

${ }^{222}$ BUTLER, supra note 23, at 195.

${ }^{223}$ For a presentation, description, and discussion of the various "levels of analysis" that scholars have created as conceptual categories to organize the study of international relations, see EAST, supra note 164 (enumerating five primary levels of analysis-personal characteristics of decisionmakers, structures of government units, political features of regimes, national attributes of societies, and properties of the international system).
} 
integrated into a theoretical model if its full explanatory and predictive potential is to be realized. ${ }^{224} \mathrm{By}$ the same token, neglect of the structure in which decisions are made can ignore important constraints within which decisionmakers identify and select between choices. All levels of analysis are necessary, and no one level is sufficient. The objective of long-term research programs should be to build bridges between the various levels of analysis rather than to force a choice between them. ${ }^{225}$ The complexity of the phenomenon under analysis generates natural resistance to reductionism.

Nevertheless, the most determinate of explanations requires that theoretical relationships between be established at the most specific level of analysis at which investigation is possible. Because none of the existing theories accord significant theoretical weight to the individual decisionmaker, the determinacy and explanatory power of resulting explanations suffer accordingly. If individual-level variables were not investigable, or not determinable, or if the results of experiments at the individual level of analysis were not generalizeable, failures to incorporate these variables into theories of IHL compliance would be defensible. If, however, the tendency to give short shrift to the role of individuals in the study of legal compliance results from a lack of capacity to employ requisite methodologies drawn primarily from other disciplines, ${ }^{226}$ or, worse, the unwillingness to invest the labor and time necessary to acquire training in these methodologies and disciplines, the sacrifice of explanatory capacity in the name of convenience and parsimony is, to put it mildly, "particularly troubling., ${ }^{\text {,227 }}$ Whatever the reasons, it is no longer adequate to simply speculate as to the existence and importance of the individual-level variables that are causally related to state compliance with IHL $^{228}$ or, still worse, to assume, because they are difficult to observe and measure, that they are irrelevant. ${ }^{229}$

\footnotetext{
${ }^{224}$ See SEARS et al, supra note 78, at 253 (stressing that individual-level variables do not provide a logically complete explanation of state behavior); see also FARRELL, supra note 32, at 43 (stating that each level of analysis must be addressed and accorded a relative measure of potency in the development of a theory of foreign policy behavior).

${ }^{225}$ LINDA O. VALENTY \& OFER FELDMAN, POLITICAL LEADERSHIP FOR THE NEW CENTURY (19).

${ }^{226}$ See FRED W. GREENSTEIN, PERSONALITY AND POLITICS 2 (1969) (suggesting that many scholars ignore the role of personality because they "do not feel equipped to analyze personality in ways that meet their intellectual standards[.]").

${ }^{227}$ Daniel L. Byman \& Kenneth M. Pollack, Let Us Now Praise Great Men, 25 INT'L SEC. 107, 108 (2001). Some scholars go so far as to brand the marginalization of the "crucial impact of individuals on war and diplomacy" and the neglect of the extent to which "social science can tease out useful generalizations regarding the role played by individuals" an "arrogant" approach to the study of international relations. Id. at 109. Others attribute this agnosticism to the methodological difficulties faced by academics untutored in psychological theories and techniques when they endeavor to probe psychohistorical processeses. See, e.g., O. FELDMAN \& L.O. VALENTY, PROFILING POLITICAL LEADERS 130 (2001); THOMAS EHRLICH, CYPRUS 1958-1967: INTERNATIONAL CRISES AND THE ROLE OF LAW 5 (1974) (suspecting the causal significance of personality to international legal compliance but declining to investigate individual-level variables in theroetical development on the ground that "[s]uch an inquiry, and the development of its methodological underpinnings, would require a complex set of tools far beyond the scope of this analysis.").

${ }^{228}$ See, e.g., Bailey, supra note 63, at 128 (stating that much of the analysis involving state compliance decisions with IHL has heretofore "involve[d] speculation into the motivations of individuals."). For nearly three decades, foreign policy scholars have bemoaned the lack of investigation at the individual level of analysis. See, e.g., WILLIAM O. CHITTICK, THE ANALYSIS OF FOREIGN POLICY OUTPUTS 4 (1975) (describing the tendency to search for explanations of state behavior in national and systemic attributes rather than in the personalities of decisionmakers).

${ }^{229}$ See FAREED ZAKARIA, FROM WEALTH TO POWER 14 (1998) (decrying scholarly tendency to discount individual-level inputs into foreign policy decisions on the grounds that they are difficult to observe and evaluate). The lack of a body of empirical research in the field of IHL compliance is a microcosm of the broader failure of the legal academy to incorporate the methods and insights of the social sciences. Compare Dennis M. Patterson, The Limits of Empiricism: What Facts Tell us, 98 MICH. L. REV. 2738, 2738 (2000) ("The conventional legal academic wisdom about empiricism is that empirical information is by-and-large a good thing, that we need more of it, and that empirical analysis is preferable to many scholarly alternatives now on offer in the law review literature."), with William L. Landes, The Empirical Side of Law and Economics, 70 U. CHI. L. REV. 167,180 (2003) It would only be a modest exaggeration to say that most law professors regard empirical work as a form of drudgery not worthy of first-class minds.").
} 
The geopolitical history of the $20^{\text {th }}$ century is inexplicable without reference to Wilson, Hitler, Stalin, Churchill, Roosevelt, Reagan, Gorbachev, and Hussein, and the "policymaking community in Washington takes it as an article of faith that who is the prime minister of Great Britain, the chancellor of Germany, or the king of Saudi Arabia has real repercussions for the United States and the rest of the world." 230 That this is so is because people, not states, make decisions, and because people, not states, are the primary actors in the international system. Personality ${ }^{231}$ matters in international relations and in international law, and war, along with the decisions regarding its commencement, prosecution, and conclusion, may well "begin[] in the minds of men"232 and women. If so-if "what you decide depends ultimately upon who you are"233 - then the answers to the " "why?" questions in international relations",234 and international law will remain beyond our ken unless and until we accept this methodological imperative and turn inward to probe the decisionmaking process itself. While the proposition that individuals are indispensable to the explanation of their decisions ${ }^{235}$ might strike some observers as intuitively obvious, it is one thing to sense that personality is crucial, but quite another to specify how, when, and above all why it is so. What we suspect is greater than what we know. A worthwhile theory of IHL compliance must offer a precise and accurate description of compliance decisions, a parsimonious yet valid explanation of compliance and noncompliance, and the promise of reliable prediction. Accordingly, Part II elaborates a positive theory ${ }^{236}$ that treats state decisions and judgments regarding compliance with the sub-regime of IHL governing the resort to self-defense as dependent variables explainable by the incorporation of individual-level independent variables within the chain of causation.

\section{A Personality Theory of IHL Compliance}

\section{A. Personality Theory}

\section{Political Psychology}

The century-old ${ }^{237}$ field of political psychology [“PP”] posits the individual as not merely causally significant but rather as central to explanations and predictions of the political behavior of collective entities. $^{238}$ Individuals are not prisoners of fell circumstances but rather exert positive influence on the

\footnotetext{
${ }^{230}$ (note).

231 "Personality" is the unique and systematic pattern of cognitive, affective, and behavioral functioning that each individual manifests in response to a range of internal and environmental stimuli. JERROLD M. POST, THE PSYCHOLOGICAL MEASUREMENT OF POLITICAL LEADERS 69 (2003). Although personalities can be classed into typologies, individual personality is as unique as a fingerprint and remarkably stable over a range of behaviors and inputs and over time. Id. Personality theory contends that a strong causal relationship exists linking personality with decisional style and preferences. See, e.g., ROSENAU, supra note 222 , at 89.

${ }^{232}$ See supra note *.

${ }^{233}$ ETHEREDGE, supra note 209, at 39.

${ }^{234}$ RICHARD C. SNYDER, H.W. BRUCK, \& BURTON SAPIN, EDS., FOREIGN POLICY DECISION-MAKING 33 (1962).

${ }^{235}$ See Raymond Birt, Personality and Foreign Policy: The Case of Stalin, 14 POL. PSYCH 607, 608-09 (1987) (elaborating the "actor indispensability" thesis: that unless the same foreign policy decision would be made by all decisionmakers the role of personality is important in explaining decisions).

${ }^{236}$ A "positive" theory is distinct from a normative theory in that it attempts to state what is, and not what ought to be, and thus is falsifiable. See JAMES N. ROSENAU, COMPARING FOREIGN POLICIES 17 (1972). A positive theory includes a specification of constructs or concepts, a set of hypotheses, and criteria for explanation of behavior.

${ }^{237}$ The earliest political psychological theorization was conducted in the early $20^{\text {th }}$ century by famed Viennese psychiatrist Sigmund Freud, who postulated that political decisionmakers displaced their motives onto the public and rationalized this displacement in terms of the public interest. See HAROLD LASWELL, PSYCHOPATHOLOGY AND POLITICS 75-76 (1930).

${ }^{238}$ See SINGER \& HUDSON, supra note 193, at 256 (regarding the human decisionmaker as "much more than a mere idiosyncracy or a dismissable random error term in a formal equation").
} 
world around them. ${ }^{239}$ Although variables drawn from other levels of analysis factor into explanations of the behavior of the social abstractions called "states," because it is individual political elites, and not states, who develop and implement the policies that shape the political universe, ${ }^{240} \mathrm{PP}$ regards all political behavior as the consequence of the complex interaction of psychological phenomena in the minds of the individuals responsible for those policies. ${ }^{241}$ Thus, viewed through the prism of PP it is the psychology of individual decisionmakers that is the orienting focus for the study of international relations. Because the psychologies of decisionmakers have consequential correlates, and because each individual is endowed with a unique personal psychology, PP dictates a research agenda that can explain how "who" the decisionmaker is translates into the decisions he has made and will make. Accordingly, the political psychologist must (1) develop a theory of personality that models the causal relationship between relevant psychological variables and foreign policy decisions and accounts for variance across the broadest possible range of decisionmakers, (2) assess the relative potency of variables from other levels of analysis in terms of their contribution to decisional latitude or constraint, and integrate them into the theory.

2. General Premises and Assumptions

"Personality" refers to the "all aspects of an individual qua individual"242 that influence his behavior. ${ }^{243}$ Within personality theory ["PT"], each individual is an aggregate of a unique complex of constructs that drive a constant process of selection from among decisional alternatives. Choices are made to satisfy internal motivational, valuational, or attitudinal dispositions and preferences and to preserve desirable aspects or alter undesirable aspects of the environment as understood through the unique frame of reference supplied by the decisionmaker's personality, and it is this personality that dictates the substance and process of these choices and yields behavioral and consequential effects. ${ }^{244}$

Although PT regards decisions as deliberate and conscious, it emphatically does not presume rationality. ${ }^{245}$ In making decisions, individuals are obligated to perform a series of complex tasks, including the search for information, the ordering of preferences, the development of decisional

\footnotetext{
239 'The individual, far from being a mechanism manipulated by forces such as the 'national interest' or 'power relationships,' is a significant independent factor in the decisionmaking process." PATRICK J. McGOWAN \& HOWARD B. SHAPIRO, THE COMPARATIVE STUDY OF FOREIGN POLICY 53 (1973).

${ }^{240}$ PT assumes that through decisionmaking "individuals contribute to the situations they encounter" and "modify the situation[s][.]” DAVID MAGNUSSON, PERSONALITY AT THE CROSSROADS: CURRENT ISSUES IN

INTERACTIONAL PSYCHOLOGY 20 (1977). Although strategic position, domestic politics, and other constraints matter, the political elites invested with decisional authority can generally transcend these factors and exercise direct influence on state behavior by choosing and implementing national strategies. See generally SNYDER ET AL., supra note 235.

${ }^{241}$ See LAWRENCE S. FALKOWSKI, PSYCHOLOGICAL MODELS IN INTERNATIONAL POLITICS 304 (1979) (differentiating PP from disciplines that presume causation to flow in the opposite direction-i.e., that individual decisions are caused by the influence of variables at higher levels of sociopolitical organization). Although it recognizes that social and systemic variables exert reciprocal influence on individual decisionmakers, PP regards the causative pathway primarily directed from individuals outward. Id.

${ }^{242}$ MARGARET G. HERMANN, A PSYCHOLOGICAL EXAMINATION OF POLITICAL LEADERS 2 (1977).

${ }^{243}$ See LEROY N. RIESELBACH \& GEORGE I. BALACH, PSYCHOLOGY AND POLITICS 6 (defining personality as "what . .. the individual . .. brings into the behavioral situation.").

${ }^{244}$ See SEARS ET AL., supra note 78, at 21 (postulating that every decisional alternative is "associated with a set of beliefs about the outcomes that are potentially associated with each alternative" and are "idiosyncratic to every decision-maker.").

${ }^{245}$ See ROSENAU, supra note 222, at 195 (describing decisions as "more or less deliberate and conscious choices" but refraining from characterizing decisionmaking as a rational process); see also JOHN D. STEINBRUNER, THE CYBERNETIC THEORY OF DECISION: NEW DIMENSIONS OF POLITICAL ANALYSIS 138 (contending that decisions made under conditions of complexity and uncertainty cannot be explained by RCT).
} 
alternatives, and the making of choices, ${ }^{246}$ and most are simply incapable of absorbing sufficient information and undertaking adequate evaluation to reach decisions that consistently maximize their welfare, or that of their constituents. ${ }^{247}$ The human mind is a limited instrument, and under conditions of uncertainty and complexity individuals must simplify the decisionmaking process to avoid cognitive overload and reach closure. ${ }^{248}$ As former Secretary of State Henry Kissinger explains,

During fast-moving events those at the center of decisions are overwhelmed by floods of reports compounded by conjecture, knowledge, hope, and worry. These must be sieved through their own preconceptions. Only rarely does a coherent picture emerge; in a sense coherence must be imposed on events by the decisionmaker[.] $]^{249}$

To lighten their burdens, decisionmakers unconsciously resort to heuristic mechanisms that conserve mental resources by creating shortcuts to judgments. ${ }^{250}$ These various mechanisms—beliefs, images, values, experiences, motivations, attitudes, perceptions, operational codes, and traits-represent the basic constituents of personality and function as the primary determinants of decisions. Identifying the relevant set of mechanisms, or constructs, operative in the decisionmaking context affords valuable insight into the explanation and prediction of behavior. ${ }^{251}$ Establishing the process whereby these mechanisms influence decisional tasks permits the generation of testable propositions and the development of a theory. ${ }^{252}$ To explain and predict behavior thus requires the conceptualization of the role of personality with behavioral referents for specific constructs.

\section{c. Personality Constructs}

a. beliefs

"Beliefs" are internalized scripts about the nature of reality and about expected or preferred future outcomes $^{253}$ that create a set of cognitive predispositions that shape the manner in which incoming information is processed and interpreted. ${ }^{254}$ Individuals acquire a systematic tendency to see what they expect to see on the basis of the content of beliefs that they acquire early in life ${ }^{255}$ and which exert great influence upon

the individual's interpretation of events, and thus the individual's identification of when there is a need or opportunity for making a choice; the individual's choice and use of information, the individual's definition of what constitutes realistic alternative courses of action, and what values are considered in a choice between alternative(s) ... [Beliefs] influence the actor's definition of both the objectives and alternative

\footnotetext{
${ }^{246}$ See ALEXANDER GEORGE, PRESIDENTIAL DECISIONMAKING IN FOREIGN POLICY: THE EFFECTIVE USE OF INFORMATION AND ADVICE 10 (enumerating decisional tasks).

${ }^{247}$ See YAACOV Y.I. VERTZBERGER, THE WORLD IN THEIR MINDS: INFORMATION PROCESSING, COGNITION, AND PERCEPTION IN FOREIGN POLICY 21 (1990) (noting that the inability to process information opens decisionmakers to the prospect of "bias and error" that yield "particularly serious consequences such as loss of life, material damage, and wounded national morale[.]").

${ }^{248}$ See CHARLES F. HERMAN, CHARLES W. KEGLEY, JR., \& JAMES N. ROSENAU, EDS., NEW DIRECTIONS IN THE STUDY OF FOREIGN POLICY 210-11 (describing heuristic techniques decisionmakers use to simplify decisional tasks).

${ }^{249}$ SINGER \& HUDSON, supra note 193, at 96 (quoting former U.S. Secretary of State Henry Kissinger).

${ }^{250}$ VERTZBERGER, supra note 248, at 113. For a recent discussion of this phenomenon in the context of domestic legal decisionmaking, see generally Daniel Simon, A Third View of the Black Box: Cognitive Coherence in Legal Decisionmaking, U. CHI. L. REV._(2004).

${ }^{251}$ POST, supra note 232, at 77-78.

${ }^{252}$ See FALKOWSKI, supra note 242, at 10 (describing this phase of theorization as "process-tracing").

${ }^{253}$ Beliefs are essentially statements about relationships between cause and effect. See DANIEL HERADSTVEIT, THE ARABISRAELI CONFLICT: PSYCHOLOGICAL OBSTACLES TO PEACE 20 (1979) ("If a man perceives some relationship between two things or between some thing and a characteristic of it, he is said to hold a belief.").

${ }^{254}$ SEARS ET AL., supra note 78, at 264.

${ }^{255}$ See JERVIS, supra note 208, at 281 (tracing beliefs and perceptions to early first-hand experiences).
} 
courses of action available to his opponent, and the actor's perception of the likely consequences of his own and his opponent's actions. ${ }^{256}$

Individuals are systematically more receptive to information that is consistent with their beliefs than to information that contradicts them, and decisionmakers are prone to selectively process information in such a manner as to lend support to their belief systems, ${ }^{257}$ particularly under conditions of situational complexity, informational uncertainty, lack of historical guidance, time pressure, and stress. ${ }^{258}$ Relevant actors seek information and then structure reality in a manner consistent with their beliefs and in so doing selectively ignore or fail to integrate necessary information, building bias into their decisionmaking. ${ }^{259}$ When confronted with repeated inconsistencies between belief systems and the empirical world, individuals, to avoid cognitive dissonance, must either modify their beliefs or disconfirm the validity of inconsistent information. However, so powerful are beliefs in dictating perceptions and decisions that individuals exhibit a strong tendency to resist adaptation and to structure their interactions with other actors in a manner consistent with the content of their beliefs regardless of contrary empirical evidence. $^{260}$

In other words, beliefs are remarkably stable conceptual anchors that resist reality, and it is the variance in the constellations of beliefs that constitute individual personalities that explains, in some measure, variance in diagnostic and decisional propensities. Beliefs may be hierarchically organized around a small set of master beliefs, and operational code and cognitive mapping models ${ }^{261}$ suggest that the most central, stable, consistent, and, therefore, theoretically relevant beliefs as regards theories of international relations are those concerning the fundamental nature of human beings (good or evil), the nature of politics (conflictual or cooperative, malleable or predetermined, predictable or unpredictable), the value of human life, the role of chance, and the nature of the opponent. ${ }^{262}$

b. images

"Images" are the accumulated understandings about himself and the world an individual organizes into an affective and evaluative structure to simplify decisionmaking. ${ }^{263}$ Although images may reflect empirical reality, they are subjective interpretations: individuals "respon[d] not only to the 'objective' characteristics of a situation, but also to the meaning the situation has for [the]m." 264

\footnotetext{
${ }^{256}$ HERADSTVEIT, supra note 254, at 11.

${ }^{257}$ SEARS ET AL., supra note 78, at 264.

${ }^{258}$ HERMANN ET AL., supra note 249, at 206-07.

${ }^{259}$ See generally R. NISBETT \& L. ROSS, HUMAN INFERENCE: STRATEGIES AND SHORTCOMINGS OF SOCIAL JUDGMENT (1980) (describing processes whereby decisionmakers simplify, but distort, reality).

${ }^{260}$ See MICHAEL BRECHER, CRISES IN WORLD POLITICS 12 (1993).

${ }^{261}$ See generally Alexander L. George, The "Operational Code": A Neglected Approach to the Study of Political Leaders and Decision-Making, 13 INT'L STUD. Q. 190 (elaborating a belief-system theory termed "operational code" analysis); MARTHA L. COTTAM, FOREIGN POLICY DECISION MAKING: THE INFLUENCE OF COGNITION 9-17 (1986) (tracing the development of operational code modeling and second-stage "cognitive mapping" models).

${ }^{262}$ See, e.g., David G. Winter, Margaret G. Hermann, Walter Weibtraub, \& Stephen G. Walker, The Personalities of Bush and Gorbachev Measured at a Distance: Procedures, Portraits, and Policy, 12 POL. PSYCH. 215, 221 (1991). A belief is considered central to the degree that other beliefs in a given individual belief system are dependent upon it and to the degree that it is resistant to change over time. A belief is stable to the degree that it maintains is value as a predictor variable from situation to situation. A belief is consistent to the degree that it associates with other beliefs in a belief system. See HERADSTVEIT, supra note 254 , at $17-25$ (elaborating a belief systems theory).

${ }^{263}$ See Kenneth Boulding, National Images and International Systems, 3 J. CONFL. RES. 120 (1959) (introducing the concept of "image" to the study of international relations).

${ }^{264}$ JOHN C. FARRELL \& ASA P. SMITH, EDS., IMAGE AND REALITY IN WORLD POLITICS 16 (1967).
} 
Perhaps the most relevant image is the stereotype, defined as

a simplistic, unsophisticated belief about an individual or group that can be used to determine the proper way to think about individuals or groups and to enable decisionmakers to fit a broad range of events into well-defined, narrow categories, allowing speed and economy of mental effort . . . and justifi[cation of] particular patterns of behavior and thinking[.] $]^{265}$

Stereotypes artificially rationalize decisions by attributing admirable qualities to allies and venality to opponents, thus enhancing perceptions of the probabilities of success while introducing bias and increasing the likelihood of decisional failure. ${ }^{266}$

Stereotypes of other actors may be the master key to understanding foreign policy decisionmaking. ${ }^{267}$ If states are external abstractions that can only be experienced as an internal function, it is logical that images of states should reflect the personalities of those who experience and construct them. ${ }^{268}$ Empirical evidence suggests that the pattern of behavior directed toward a given state is congruent with the images held by the decisionmaker about the given state: a positive image corresponds with friendly, cooperative behavior, whereas a negative image corresponds with hostile, conflictual behavior. ${ }^{269}$ In short, the image of a state or other actor held by the decisionmaker firmly guides his selection of decisional alternatives with respect to that state or actor.

c. values

"Values" are normative statements about behaviors, objects, and situations that are situated along a relative continuum, superimposed upon information, and used to evaluate information. ${ }^{270}$ Values are interwoven with beliefs and images but can be modeled as separate causal factors.

d. attitudes

"Attitudes," defined as ideational formations having affective and cognitive dimensions that create a disposition for a particular pattern of behavior toward categories of objects and social situations, ${ }^{271}$ are, like values, intimately connected to images and beliefs. Individuals tend to discard information incongruent with their attitudes and to search for information that supports attitudinal proclivities. ${ }^{272}$ The most theoretically significant attitudes as identified in foreign policy research tend to be those which create predispositions to feel or act positively or negatively toward other states. ${ }^{273}$

e. traits

"Traits" are the "public, observable element of personality, the consistencies of style readily noticed by other[s]" that "reflect the language of 'first impressions,' the adjectives and adverbs of everyday language that we used to describe other people." ${ }^{274}$ Trait theorists maintain that factors such as energy level, self-confidence, communication style, organizational capacity, impulsivity, sociability,

\footnotetext{
${ }^{265}$ VERTZBERGER, supra note 248 , at 127.

${ }^{266}$ IRVING L. JANIS, GROUPTHINK: PSYCHOLOGICAL STUDIES OF POLICY DECISIONS AND FIASCOES 112 (1982).

${ }^{267}$ FALKOWSKI, supra note 242 , at 301.

${ }^{268}$ See ETHEREDGE, supra note 209, at 59 (“(M)an experiences other nations internally: they are creations which embody his emotions, and projective intuition shapes them in his reality.").

${ }^{269}$ CHITTICK, supra note 229, at 52 (surveying research).

${ }^{270}$ VERTZBERGER, supra note 248, at 124.

${ }^{271} I d$. at $127-28$.

${ }^{272}$ FARRELL \& SMITH, supra note_, at 20.

${ }^{273}$ ALAN C. ELMS, PERSONALITY IN POLITICS 11-14 (1976).

${ }^{274}$ SEARS ET AL., supra note 78, at 115.
} 
emotional expressiveness, intelligence, extraversion, and sensitivity ${ }^{275}$ are stable behavioral dispositions that exert latent influence upon individual choices and behaviors. ${ }^{276}$

f. motives

"Motives" are latent dispositions that direct decisionmakers to define situations, make evaluative judgments, mobilize energy and resources, and selectively pursue end states in the empirical world. ${ }^{277}$ Researchers identify needs for power, achievement, and affiliation as among the most theoretically important motives in explaining decisionmaking in international relations. ${ }^{278}$

g. summary

Whether scholars incorporate beliefs, images, values, attitudes, traits, motives, or other personality constructs in their decisionmaking models, each term references a mechanism operant in the mind of an individual faced with uncertainty and time constraints which filters, orders, simplifies, and explains the political universe while facilitating the task of identifying, evaluating, and selecting from between decisional alternatives. For purposes of simplicity and clarity, the general term "personality construct" references each of the various elements of personality described herein.

\section{d. Measuring Personality}

Problems with data access hamper the development and testing of a PT model of decisionmaking. Attempts to specify the manner in which personality translates into foreign policy decisions require the opening of the black box of the decisional unit to ascertain precisely what decisionmakers think, say, and do during the decisionmaking process, yet this is generally impossible prior to the declassification of official records. Moreover, public officials tend to zealously guard national and personal secrets, and what data leaks to the research and lay communities, such as memoirs, retrospective accounts, and secondary source materials, tend to be less than completely reliable, ${ }^{279}$ particularly while principals are still alive. ${ }^{280}$ Similarly, assessments of the link between personality and foreign policy decisionmaking which rely on literature reviews, insider interviews, and biographies, are subject to validity problems due to temporal and spatial distance from the subject, deliberate or unintentional deception, faulty interview designs, and human fallibility. ${ }^{281}$ Content analysis has been utilized as an alternative form of personality measurement in all the major studies which have applied PT to foreign policy analysis, ${ }^{282}$ yet it too is beset with validity problems. Speeches, interviews, and private conversations may not reflect the true beliefs, images, or values of decisionmakers or offer a faithful guide to their personalities. ${ }^{283}$

Establishing the role of personality in the decisionmaking process requires a measurement protocol. Direct measurement is possible through interviews by psychiatrists and psychologists, direct

\footnotetext{
${ }^{275}$ POST, supra note 232, at 31 (indexing relevant traits); FELDMAN \& VALENTY, supra note 228, at 235-45 (same).

${ }^{276}$ MAGNUSSON, supra note 241 , at 13.

${ }^{277}$ ROSENAU, supra note 237 , at 248.

${ }^{278}$ See, e.g., Ole Holsti, The Political Psychology of International Politics, 10 POL. PSYCH. 495, 497-98 (1989).

${ }^{279}$ SINGER \& HUDSON, supra note 193, at 220 (noting that information revealed about the Cuban Missile Crisis in the mid1990s called into question the reliability of broad categories of such data).

${ }^{280}$ See POST, supra note 232, at 11 (noting that after decisionmakers die more information becomes available through declassification and because third parties are no longer reluctant to discuss matters that might have been prejudicial to the interests of the deceased while yet alive).

${ }^{281}$ ETHEREDGE, supra note 209, at 71.

${ }^{282}$ SINGER \& HUDSON, supra note 193, at 108.

${ }^{283}$ FALKOWSKI, supra note 242 , at 8.
} 
observation, and formal tests. However, unless decisionmakers submit to psychometric testing or clinical anamnesis, ${ }^{284}$ personality must be inferred from behavior. The "psychobiographical approach," or "assessment at a distance,", ${ }^{285}$ establishes an a priori measurement protocol and then gathers all possible sources, including letters, speeches, interviews, documents, newspapers, autobiographies, anecdotal evidence, and direct observation data, to generate an explicit, valid, and reliable assessment of personality. ${ }^{286}$ Psychobiographers engage in an iterative process of data collection, aggregation, and testing, comparing each source to the others, to judge the reliability and validity of empirical data. ${ }^{287}$ PT scholars draw upon this psychobiographical data to "score" decisionmakers on those personality constructs hypothesized to give rise to variance in the political behaviors under analysis, with the ultimate objective the explanation of how particular combinations of personality constructs, known as "personality profiles," direct decisionmakers to elect particular decisions and, in turn, produce specific behaviors. ${ }^{288}$

5. Conditionality and Contingency: Other Levels of Analysis

The relationship between personality and state behavior is one of contingency: assertions of causality are couched by PT theorists as true only in some cases and under certain conditions, and caution must be exercised when generalizing from their findings. ${ }^{289}$ Individuals make decisions within a wide range of decisional environments, and they are constrained and influenced, to greater or lesser extent, by external political, economic, and social realities, ${ }^{290}$ as well as by the culture of relevant governmental bureaucracies $^{291}$ and domestic public opinion. Although more powerful states face fewer external limitations than weaker states, and hegemons face even fewer, no state, and therefore no decisionmaker, is omnipotent. However, the influence of exogenous constraints is bounded.

\footnotetext{
284 "Anamnesis," a form of psychoanalysis, is the process whereby the life course of the individual is reconstructed to understand how particular experiences shaped core beliefs, attitudes, and images and influence present decisionmaking behavior. See POST, supra note 232, at 70 (discussing the use of anamnesis in the context of personality theorization).

${ }^{285}$ See MARGARET G. HERMANN, ASSESSING LEADERSHIP STYLE: A TRAIT ANALYSIS (1999) (labeling content analysis of interviews the "Personality Assessment at a Distance" approach).

${ }^{286}$ See D.K. Simonton, Presidential Style: Personality, Biography, and Performance, 55 J. PERSON. \& SOC. PSYCH 928 (1988) (describing the data available to psychobiographers and the process used to generate personality-based hypotheses); VALENTY \& FELDMAN, supra note 226, at 105 (same). The psychobiographical approach has adherents in academia as well as in the halls of government: the U.S. Central Intelligence Agency Center for Analyis of Personal Political Behavior has catalogued personality studies for a broad range of political elites across the globe and uses biographies, media profiles, debriefings of senior officials who have had extended contact with elites, and other sources to gather data and assemble personality profiles. POST, supra note 232, at 55.

${ }^{287}$ See JEANNE N. KNUTSON, ED., HANDBOOK OF POLITICAL PSYCHOLOGY 307-18 (1973) (describing the psychobiographical approach to personality assessment). Most psychobiographies draw heavily upon books written by authors who knew and had protracted contact with their subjects, and validity is high since these authors typically interview hundreds of people who knew the decisionmakers from the very beginning of the lives and from divergent vantage points. VALENTY \& FELDMAN, supra note 226, at 107. Although authors may disagree in some of the particulars of their appraisements, the zone of disagreement is generally rather limited, and intercoder reliability is high. Id.

${ }^{288}$ See POST, supra note 232, at 13-14 (describing psychobiography as the description of non-rational behavior, the explanation of that behavior in terms of personality, and the tracing of the development of personality through the life of the decisionmaker).

${ }^{289}$ KNUTSON, supra note 288, at 29.

${ }^{290}$ In authoritarian states, a predominant leader may be relatively unconstrained by domestic institutions and interests. SEARS ET AL., supra note 78, at 253 (suggesting that in a highly centralized state the preferences of the head of state may be dispositive of state behavior even during routine circumstances). By contrast, in liberal states, countervailing institutional preferences may routinely exert significant influence on the decisionmaking process.

${ }^{291}$ See IRVING L. JANIS \& LEON MANN, DECISION MAKING: A PSYCHOLOGICAL ANALYSIS OF CONFLICT, CHOICE, AND COMMITMENT 120 (1977) (discussing influence of foreign policy bureaucracies and small advisory teams upon decisionmakers during performance of routine tasks and noting that "groupthink" can overcome effects of personality, particularly in noncrisis situations); see also MOORE, supra note 70, at 42-43 (concluding that the most critical variable for explaining state behavior is the structure of government bureaucracies, as these institutions "bring[] to power those who may be disposed to aggressive military adventures and in creating incentive structures predisposing to high risk behavior.").
} 
The role occupied by the individual is relevant to assessing the weight attributable to personality in PT. The individual at the apex of the state hierarchy is invested with maximum decisional autonomy, ${ }^{292}$ and may be more impervious to other inputs than previously imagined ${ }^{293}$ even if he or she does not command an authoritarian regime. ${ }^{294}$ Head decisionmakers ["HDs"], ${ }^{295}$ whether by the textual commitments of constitutions or by tradition, are invested with the greatest quantum of power relative to other domestic actors in the field of foreign policy, ${ }^{296}$ and as decisional freedom increases the role of exogenous constraints diminishes.

Furthermore, situational context is crucial, and constraints ebb with the nature of the impetus toward decisionmaking, and with the issue-area in question. During situations of heightened ambiguity, instability, and uncertainty, PT accords far greater causal weight to personality constructs than to other variables, ${ }^{297}$ and an absence of precedent, increased time constraints, and increased emotional stress further diminish the theoretical significance of exogenous factors. ${ }^{298}$ Responsibility follows power, and HDs, upon whom the ultimate responsibility for power rests heavily, tend to rely less upon external sources of guidance when their state is subject to external threat. Because the role of government bureaucracies and the influence of domestic opinion contracts during conditions of ambiguity or

\footnotetext{
${ }^{292}$ See HERMANN, supra note 243, at 2 (identifying the head-of-state, the "individual who has the authority to commit the resources and select the goals of a political unit, and, in turn, to affect its policies," as the focal point of the analysis of foreign policy decisionmaking). Even the most liberal of states repose great power and decisional autonomy in their heads of state. See POST, supra note 232, at 1452 ("Modern democracies place individuals at their helm with access to immense power and, of necessity, grant them enormous discretion in its use.").

${ }^{293}$ See SHAI FELDMAN, U.S. MIDDLE EAST POLICY: THE DOMESTIC SETTING 20 (1988) (“[Head decisionmakers] don't act contrary to their beliefs because of domestic political constraints . . They may adjust, they may moderate their positions, they may manipulate ... decisions, so they may look one way before an election and they may look another way after an election . . . but that is different from manipulating . . . policy."); see also STEVEN L. SPIEGEL, THE OTHER ARABISRAELI CONFLICT: MAKING AMERICA'S MIDDLE EAST POLICY FROM TRUMAN TO REAGAN 10 (1985) (stating that domestic interest groups constrain and influence foreign policy but do not alter presidential decisions and that "in the end, policy can be understood only by examining an administration's foreign policy priorities, philosophical assumptions, decisionmaking system, and key personalities.").

${ }^{294}$ Even in the most rational, mature, rule-of-law democracies, the head decisionmaker wields significant foreign policy decisional authority. See GREENSTEIN, supra note 227, at 3 ("If some higher power had set out to design a democracy in which the individual on top mattered, the result might well resemble the American political system.").

${ }^{295}$ Although enriched theories of state behavior require an account of the influence of the personalities of individuals other than HDs, such as generals, diplomats, and key religious authorities, PT has centered its research agenda heretofore upon the HD, who possesses final authority to commit the state to decisions. Byman \& Pollack, supra note 228, at 146.

${ }^{296}$ Although domestic issues have external consequences, and vice versa, foreign policy is generally regarded as an issue qualitatively distinct from domestic policy, and HDs are generally granted broader latitude to place their stamp upon the conduct of the state in its external relations, particularly those involving the use of force, than they are with respect to domestic issues. See TETREAULT \& ABEL, supra note 204, at 25-26 (noting that the U.S. Congress has traditionally been able to dominate foreign policy on economic issues, but presidents have dominated foreign policy on national security questions); see also RICHARD SNYDER \& EDGAR S. FURNISS, AMERICA'S FOREIGN POLICY 189 (1954) ("Public opinion may inspire or hamper, Congress may push or restrain, aides may give advice, but in the last analysis, the President must decide."). This "inside-outside" distinction pertains to Western liberal, as well as authoritarian, regimes:

In the U.S. context, American presidents face fewer institutional constraints in the real of foreign policy than they do in domestic policy, where congressional involvement is normally required to make or implement policy decisions. In foreign policy, with the exception of Congress's role in ratifying treaties and declaring war, U.S. presidents usually serve as the chief architects and executors of the nation's policies.

PAUL ‘T HART, ERIC K. STERN, \& BENGT SUNDELIUS, BEYOND GROUPTHINK 193 (1997).

${ }^{297}$ See MAGNUSSON, supra note 241, at 333 ("[Personality] can determine behavior ... most strongly when the situation is ambiguously structured ... so that people are uncertain about how to categorize it, have to structure it in their own terms, and have no clear expectations about the behaviors most likely to be appropriate ... in that situation.").

${ }^{298}$ See, e.g., JOAN OFFERMAN-ZUCKERBERG, ED., POLITICS AND PSYCHOLOGY 141 (stating that personality constructs "are most apt to be important in times of crisis, real or perceived, when leaders are under a great deal of stress."); WILLIAM B. QUANDT, DECADE OF DECISION 35 (1979) (concluding that crises diminish exogenous constraints and magnify the importance of personality); ETHEREDGE, supra note 209, at 5 (stating that crisis decisionmaking is "in large part" a function of the personality of the HD).
} 
uncertainty, ${ }^{299}$ the salience of exogenous constraints is at a nadir and the role of the personality of the HD in the chain of causation resulting in state behaviors is at a zenith in the buildup to, and during, conflict and war. ${ }^{300}$ Although legislative and bureaucratic actors, and to some extent public opinion, can be influential on questions of war and peace, ${ }^{301}$ when a HD projects force outward institutional constraints wither. $^{302}$

While the relationship between personality and decisionmaking may be contingent and conditional it is positive, and the foreign policy behaviors of a state, and in particular those involving the use of armed force, reflect the personality of the HD at the helm of the state and are inexplicable without reference thereto. ${ }^{303}$ Although PT does not advance the "naïve view of political outcomes as merely the projection of leaders' personalities," neither does it accept the "equally simplistic view that individual personalities have no effect." ${ }^{304}$ If PT concedes that personality-based theories are often supplemental to, rather than replacements for, more general and abstract explanations, ${ }^{305}$ it nevertheless insists that under delimited circumstances the personality of the HD contributes in causally significant measure to the formation and implementation of policy choices. ${ }^{306}$ In sum, although it is insufficient to the development of a general theory of foreign policy, the singular importance of personality to the explanation and

\footnotetext{
${ }^{299}$ See FALKOWSKI, supra note 242, at 310 (stating that during crises the governmental decisionmaking process becomes centralized under the aegis of the HD).

${ }^{300}$ See Betty Glad, Black and White Thinking: Ronald Reagan's Approach to Foreign Policy, 4 POL. PSYCH. 33, 69 (1984) ("[I]n the foreign policy arena, particularly during crisis situations, the [head decisionmaker] has the freedom to act on his own. Institutional and cultural constraints are apt to be lacking when he projects outward[..]"); see also ROBERT AXELROD, EVOLUTION OF COOPERATION 30 (1984); Byman \& Pollock, supra note 228, at 109.

${ }^{301}$ The influence of public opinion on state decisionmaking in regard to questions of war and peace is beyond the scope of this Article. For an argument that the influence of domestic opinion is "severely circumscribed in time of war," see Baxter, supra note 62, at 84. For a counter-argument, see JOHN MUELLER, POLICY AND OPINION IN THE GULF WAR (1994).

${ }^{302}$ See GREENSTEIN, supra note 227, at 4 ("The power of the [HD] manifests itself in its purest form in the global arena, where [his] actions as commander in chief can determine the fate of the human race ... [His] latitude for independent action is even greater in the unstructured post-cold war world than it was during the cold war, when the threat of mutual destruction concentrated minds and constrained actions.") (assessing the relative power of the U.S. President on questions of national security); VALENTY \& FELDMAN, supra note 226, at 3 ("The qualities that distinguish one chief executive from another have their greatest potential impact in the realm of national security[.]").

${ }^{303}$ See GREENSTEIN, supra note 227, at 189 ("To a startling degree [U.S. foreign policy] reflects the character and personality of the President.") (quoting former presidential adviser Clark Clifford); Christopher C. Joyner, Dissecting the Lawfulness of United States Foreign Policy: Classroom Debates as Pedagogical Devices, 9 ILSA J. INT'L \& COMP. L. 331 , 333 (2003) (“The political ideology of [HDs] in ... [a] government will determine the way in which that government perceives international affairs, and those perceptions are the main ingredients for . . policy options and action choices."); QUANDT, supra note 299, at 28 (concluding that the study of leaders' personalities yields the greatest insight into explaining and predicting their foreign policy decisions); SPIEGEL, supra note 294, at 390 ("foreign policy can be understood only by studying the ideas, the attitudes, and the experiences of the 'people at the top.'”); JONAS DAVID BARBER, THE PRESIDENTIAL CHARACTER:

PREDICTING PERFORMANCE IN THE WHITE HOUSE 3 (1985) (stating that understanding the personality of a HD is "crucial" to predicting his or her foreign policy decisions).

${ }^{304}$ POST, supra note 232 , at 1 . Although variables drawn from other levels of analysis may be causally significant to many research questions, PT contends that much of the variance can often be explained by individual-level variables. Id.

${ }^{305}$ In constructing any theory of complex processes, particularly those involving human agency, is inevitable that a degree of reductionism will be employed. Nonetheless, PT maintains that if it can be demonstrated that personality alone can explain much of the variance in decisionmaking and state behavior, then a predominant focus on personality cannot be readily dismissed as reductionist. Moreover, by reducing the number of experimental variables, the parsimony and investigability of resulting research questions are enhanced. For a discussion of potential criticisms of PT generally and the model propounded supra in this Article, see infra at pp._.

${ }^{306}$ See 'T HART ET AL., supra note 297, at 6 (describing PT as a "counterweight to more general, abstract, and parsimonious theories of international relations and foreign policy" which is "geared toward explaining policies that are at odds with predictions based upon ... rational choice ... models of international politics[.]"); see also DONALD GREEN \& IAN SHAPIRO, PATHOLOGIES OF RATIONAL CHOICE 204 (1994) (arguing more generally that we should conceive of social science "less as a prizefight between competing theoretical perspectives . . . and more as a joint venture in which explanations condition and augment one another[.]").
} 
prediction of state behavior in certain circumstances where HDs make essentially unconstrained and authoritative decisions is an "existential reality.",307

\section{B. An Integrated Pretheory of IHL Compliance}

1. Introduction

Although a diverse array of theories can be subsumed within the rubric of PT, ${ }^{308}$ all treat empirical behavior(s) as the explanandum - the thing(s) to be explained - and one or more personality constructs as the explanans - the explanatory variables. ${ }^{309}$ In other words, state behaviors are dependent variables that are the end result of a chain of causation that runs through the personality of the individual who sets the course the state will follow, and the personality constructs that constitute this unique personality are independent variables. ${ }^{310}$ A review of the historical record of state IHL compliance suggests that a model which allows for psychobiographical measurement of several policy-relevant personality constructs may enable enriched explanations of compliance decisions while retaining parsimony. In the development of an integrated theoretical model an effort will be made to enumerate and define the personality constructs operant in the personalities of HDs responsible, via the selection of IHL compliance decisions, for particular outcomes; this accomplished, a set of preliminary hypotheses based upon the causal linkages between personality constructs and compliance decisions and outcomes shall be offered and tested.

\section{Independent Variables: Personality Constructs}

The proposed theory of IHL compliance hypothesizes that the presence or absence of four constructs in the personalities of HDs are responsible for state compliance with or violation of IHL; in the theoretical model these personality constructs, which serve as independent variables, are "militarism," "anomism," "hostility," and "adventurism."

a. militarism

"Militarism" is a global construct consisting of numerous subconstructs that tap a set of intercorrelated beliefs, values, images, and attitudes. The militarist is more likely to consider military alternatives than his nonmilitaristic counterpart, more prone to escalate conflictual situations, and more likely to lead his state to war. ${ }^{311}$ Nationalism and a favorable attitude toward power have been identified as the subconstructs most predictive of the level of conflict and cooperation associated with a decisionmaker both cross-sectionally and longitudinally ${ }^{312}$ nonetheless, all thirteen subconstructs that typify the militarist, specifically nationalism, a favorable attitude toward power, patriotism, aggression, authoritarianism, militarism, competitiveness, dogmatism, introversion, isolationism, ambitiousness, low self-esteem, and military experience are incorporated in the theoretical model. The ideal-typic ${ }^{313}$ militarist

\footnotetext{
${ }^{307}$ BARBER, supra note 304 , at 521.

${ }^{308}$ See KNUTSON, supra note 288, at 29 (surveying theories in brief).

${ }^{309}$ SINGER \& HUDSON, supra note 193, at 248-49.

${ }^{310}$ See Joyner, supra note 304, at 333 ("[I]t is . . government officials who ultimately decide whether, when, how much, and under what particular circumstances [states] will or will not obey a certain rule of international law.").

${ }^{311}$ See, e.g., DONALD SYLVAN \& STEVE CHAN, EDS., FOREIGN POLICY DECISION MAKING: PERCEPTION, COGNITION, AND ARTIFICIAL INTELLIGENCE 108-09 (1984) (suggesting personality attributes of militarist or "warlike" decisionmakers); VERTZBERGER, supra note 248, at 172 (same); SINGER \& HUDSON, supra note 193, at 92.

${ }^{312}$ FALKOWSKI, supra note 242, at 44; SINGER \& HUDSON, supra note 193, at 87.

313 "Ideal types" are theoretical constructs that model selected aspects of the empirical world and permit comparative assessment of the extent to which those aspects exist in a particular real case. See Max Weber, "Objectivity" in Social Science and Social Policy, in THE METHODOLOGY OF THE SOCIAL SCIENCES 49 (Edward A. Shils \& Heary A. Finch trans. \& eds. 1949).
} 
scores high, indicating the presence of the subconstruct in his or her personality profile to an extent significantly greater than the average person, on each subconstruct.

i. subconstructs of militarism

"Nationalism" is a belief that one's nation is superior to and more honorable than other nations by virtue of its superior culture, tradition, race, ethnic composition, philosophy of government, or other characteristic(s), ${ }^{314}$ as well as the motivation to "develop, protect, maintain, or refine" this culture, tradition, race, or philosophy. ${ }^{315}$ Nationalists are more prone to defend fellow nationals in word and in deed, and more likely than non-nationalists to serve in the armed forces of their state of nationality. ${ }^{316}$ On the other hand, nationalists are less able to make subtle distinctions and gradations than are nonnationalists. ${ }^{317}$ Nationalism is positively intercorrelated with other subconstructs, including militarism, authoritarianism, dogmatism, isolationism, and a favorable attitude toward power. ${ }^{318}$ The foreign policy outputs of nationalists tend to be more conflictual than those associated with their non-nationalist counterparts, ${ }^{319}$ and these effects are heightened in the context of cultural dissimilarities between the nationalist and the target of foreign policy. ${ }^{320}$

"Favorable attitude toward power" ["FAP"] is a composite subconstruct which refers to the beliefs held by the individual in the desirability and utility of possessing and employing force in the pursuit of objectives. Specific indicators include positive attitudes toward the military, nuclear weapons, war, coercion, and control over others. ${ }^{321}$ FAP is positively intercorrelated with competitiveness, authoritarianism, aggression, isolationism, ambitiousness, and distrust. ${ }^{322}$ The militarist believes that power, and in particular military power, is essential to preserving international peace ${ }^{323}$ and thus has a strongly favorable attitude toward power and the use of force. ${ }^{324}$

"Patriotism" is the "attachment [felt] by group members to their group and the state in which they reside" that motivates individuals to be willing to sacrifice personal goals and individual well-being for the benefit of the group. ${ }^{325}$ Patriotism is positively intercorrelated with nationalism.

"Aggression" is the trait that directs an individual to engage in self-assertive, self-protective, domineering, hostile, and/or violent interactions with others. ${ }^{326}$ Aggression is positively intercorrelated with FAP, isolationism, and low self-esteem. ${ }^{327}$

\footnotetext{
${ }^{314}$ Paul C. Stern, Why do People Sacrifice for their Nations?, 16 POL. PSYCH. 217, 217 (1995).

${ }^{315}$ VAMIK VOLKAN, THE NEED TO HAVE ENEMIES AND ALLIES 88, 94-95 (1988) (describing "hyper-nationalists" as convinced that their nationality harbors "the human identity").

${ }^{316}$ H. Denker, D. Malova, \& S. Hoogendoorn, Nationalism and Its Explanations, 24 POL. PSYCH. 345, 350 (2003).

${ }^{317}$ Winter et al., supra note 263, at 231.

${ }^{318}$ See Denker et al., supra note 317, at 380 (identifying correlates of nationalism); FALKOWSKI, supra note 242, at 34 (same).

${ }^{319}$ EAST, supra note 164, at 65; SINGER \& HUDSON, supra note 193, at 88.

${ }^{320}$ COTTAM, supra note 262 , at 62.

${ }^{321}$ JANIS, supra note 267, at 69; DENNIS J.D. SANDOLE, CAPTURING THE COMPLEXITY OF CONFLICT 24 (1999).

${ }^{322}$ See Holsti, supra note 279, at 497 (identifying correlates of FAP); POST, supra note_, at 165, 190-91, (same).

${ }^{323}$ KNUTSON, supra note 288 , at 285.

${ }^{324}$ Brian D'Agostino, Self-Images of Hawks and Doves: A Control Systems Model of Militarism, 16 POL. PSYCH. 259, 265 (1999).

${ }^{325}$ SEARS ET AL., supra note 78, at 727.

${ }^{326}$ MAGNUSSON, supra note 241 , at 165.

${ }^{327}$ FELDMAN \& VALENTY, supra note 228, at 50; MAGNUSSON, supra note 241, at 166 (indicating that individuals with low self-esteem react aggressively when they believe their self-esteem is in the process of being challenged).
} 
"Authoritarianism" is the belief that the value of unquestioning obedience to authority is superior to individual freedom of judgment and that the credibility of information is a function of the authority of its source rather than of its factual reliability. ${ }^{328}$ Authoritarians rigidly adhere to conventional values and social conformity, look for and condemn violators of tradition as a social threat, and are preoccupied with hierarchies and social cohesion. ${ }^{329}$ Authoritarianism is positively intercorrelated with isolationism and nationalism. ${ }^{330}$

"Militarism" is the belief that war is a glorious and noble endeavor that serves the progressive betterment of character, culture, and civilization. ${ }^{331}$

"Military experience" imprints upon an individual who serves in the national armed forces with a set of beliefs, values, and images associated with that service, and individuals with military experience tend to acquire a "culture of war" that leaves them with a more favorable attitude toward power and conflict $^{332}$ and renders them more quick to perceive external threats. ${ }^{333}$

"Competitiveness" is the motivation to participate in a struggle against others and the belief that this struggle is necessary to the attainment of objectives and the satisfaction of wants and needs.

"Dogmatism" refers to the degree to which an individual is incapable of performing the following cognitive processes: identifying linkages between concepts; employing a great number of dimensions in the description of stimuli; utilizing a great number of rules in integrating components into a coherent whole; tolerating contrary beliefs; objectively evaluating ideas with which he disagrees; employing contingency analyses; adapting to ambiguity; generating alternatives; assimilating cues, particularly those that run counter to preconceptions, from the external environment; and perceiving shades of grey and nuances as opposed to thinking in "black and white." 334 Dogmatism correlates with aggression, authoritarianism, and competitiveness. ${ }^{335}$

"Introversion" describes an attitude and a trait in which an individual directs his interests and attention inward to his own thoughts and experiences rather than outward to external objects or people. Introverts are less vulnerable to social pressure but less resistant to assimilating external cues than are extroverts. ${ }^{336}$ Introversion is positively intercorrelated with aggression and FAP. ${ }^{337}$

\footnotetext{
${ }^{328}$ VERTZBERGER, supra note 248 , at 172.

${ }^{329}$ See generally T.W. ADORNO, E. FRENKEL-BRUNSWICK, \& D.J. LEVINSON, THE AUTHORITARIAN

PERSONALITY (1950); Stanley Feldman, Enforcing Social Conformity: A Theory of Authoritarianism, 24 POL. PSYCH. 41, 41-51 (2003).

${ }^{330}$ See generally Daniel J. Levinson, Authoritarian Personality and Foreign Policy, 1 J. CONFL. RES. 37 (1957).

${ }^{331}$ See JOHANN K. BLUNTSCHLI, DES MODERNE KRIEGSRECHT (1866) ("War is an element of the world order established by God" which fosters the "noble virtues of man-courage, self-sacrifice, obedience"); HELMUT VON MOLTKE, STRATEGY (1895) ("War fosters the noble virtues of man, courage, self-denial, obedience to duty, and ... the spirit of sacrifice.") (cited in K.L. Nelson \& S.C. Olin, Why War? (1979)).

${ }^{332}$ See SANDOLE, supra note 322, at 185 (suggesting that soldiers fulfil needs for recognition, self-esteem, affiliation, and meaning by their military service and that some soldiers "lament the passing of the Cold War" and with it their opportunities to continue to fulfil these needs) (citing David Hackworth, Talking "Soldier to Soldier" Behind Bars: What Tim McVeigh Was

Really Like, NEWSWEEK, Jul. 3, 1995, at 27-28) ("I've seen countless veterans . . . stumble home after the high-noon purpose

of the killing fields, missing their battle buddies and the unique dangers and sense of purpose.").

${ }_{333}^{33}$ JERVIS, supra note 208, at 8.

${ }^{334}$ For the foundational study on dogmatism, see generally MILTON ROKEACH, THE OPEN AND CLOSED MIND: INVESTIGATIONS INTO THE NATURE OF BELIEFS SYSTEMS AND PERSONALITY SYSTEMS 62 (1960).

${ }^{335}$ See CHARLES F. HERMAN, INTERNATIONAL CRISES: INSIGHTS FROM BEHAVIORAL RESEARCH 353,417 (1972) SANDOLE, supra note 322, at 20-21.

${ }^{336}$ VERTZBERGER, supra note 248, at 173.

${ }^{337}$ SINGER \& HUDSON, supra note 193, at 92.
} 
"Isolationism," also known as "alienation," is the negative value attached to interaction with others, to the nurturing of relationships, and to helping other people and groups. Isolationists lack a predisposition to establish, maintain, and restore positive relationships with others, to seek approval, and to limit the type or degree of their conflictual relationships with others. ${ }^{338}$ Isolationism is positively intercorrelated with FAP, ${ }^{339}$ aggression, ${ }^{340}$ competitiveness, ${ }^{341}$ and low self-esteem. ${ }^{342}$

"Ambitiousness" is the value attached to personal accomplishment, and ambitious individuals are predisposed to strive for success in tasks involving leadership and the demonstration of intelligence. ${ }^{343}$ Ambitiousness is positively intercorrelated with aggressiveness. ${ }^{344}$

"Low self-esteem" is the absence of a belief in one's own capability, inherent worth, and entitlement to the respect and admiration of others; individuals with low self-esteem are not selfconfident, patient, receptive to external cues, or likely to perceive themselves as competent and wellregarded by their peers, ${ }^{345}$ but are more prone to violent behavior than are those with high self-esteem. ${ }^{346}$ Low self-esteem is positively intercorrelated with aggression. ${ }^{347}$

ii. militarism: summary

The ideal-typic militarist is a nationalistic patriot with prior military service who views the use of power favorably, is an aggressive competitor and keenly ambitious, and is authoritarian and dogmatic yet introverted and isolated from others and beset with low self-esteem. While the pure ideal-typic militarist may exist only in theory, militarists score high, indicating the presence of the subconstruct in his or her personality profile to an extent significantly greater than the average person, on a majority of the subconstructs.

b. Anomism

"Anomism" consists of five subconstructs-disrespect for law, disrespect for legal authorities, amoralism, ignorance of law, and ignorance of IHL - that tap a set of intercorrelated beliefs, values, images, and attitudes regarding the rule of law. The anomist has little regard for the law or legal authorites, lacks moral or ethical qualms about violating legal obligations, and knows little of the substance of law generally and even less about IHL. In brief, the anomist is a serial and unrepentant lawbreaker. The ideal-typic anomist scores high on each subconstruct.

\section{i. Disrespect for Law}

\footnotetext{
${ }^{338}$ DAVID C. McCLELLAND, THE ACHIEVING SOCIETY 160 (1961) (analyzing the "need for affiliation” personality construct, which is the polar opposite of the "isolationism" subconstruct).

${ }^{339}$ SINGER \& HUDSON, supra note 193, at 87;

${ }^{340}$ See L. Berkowitz, J.P. Lepinski, \& E. Angelo, Awareness of Own Anger Level and Subsequent Aggression, 11 J. PERS. SOC. PSYCH. 293 (1969) (linking isolationism with aggression); David G. Winter, Power, Affiliation, and War: Three Tests of a Motivational Model, 65 J. PERS. SOC. PSYCH. 532 (1993) (same).

${ }^{341}$ Holsti, supra note 279, at 497-98.

${ }^{342}$ See Melvin Seeman, On the Meaning of Alienation, 24 AM. SOC. REV. 24 (1959) (identifying cynicism, distrust, low selfesteem, and loss of an internal locus of control as correlates of "alienation," a construct analogous to isolationism).

${ }^{343}$ MAGNUSSON, supra note 241, at 412 (differentiating individuals into "relationship-motivated" and "task-motivated" groups, with the former interested in maintaining interpersonal relationships and the latter driven by the need to demonstrate concrete evidence of achievement).

${ }^{344}$ SANDOLE, supra note 322, at 24-25 (suggesting that under conditions of threat or surprise the decisionmaker with the need for achievement-i.e., the ambitious decisionmaker-is prone to conflict rather than cooperation).

${ }^{345}$ Winter et al., supra note 263, at 222; FELDMAN \& VALENTY, supra note 228, at 73.

${ }^{346}$ SANDOLE, supra note 322, at 181.

${ }^{347}$ SINGER \& HUDSON, supra note 193, at 91.
} 
Although "[e]veryone breaks the law sometimes, and some people break it often[,]" ${ }^{348}$ for many individuals law is an object of reverence, ${ }^{349}$ and obedience to legal commands is nearly a quasireligious obligation. ${ }^{350}$ Many, and perhaps almost all, people quite simply believe that law must be obeyed for the simple reason that it is law. ${ }^{351}$ The anomist, in contrast, accords no independent normative value to legal obligations and regards legal obedience in purely instrumental terms: if obeying the law suits his selfinterest, he does so, but if obedience thwarts the pursuit of his ends, law is but another objective impediment that must be overcome or negotiated away. ${ }^{352}$ Disrespect for law is negatively correlated with educational attainment. ${ }^{353}$

\section{ii. Disrespect for Legal Authority}

Respect for legal authority is widely diffused across demographic, cultural, and geographic domains. ${ }^{354}$ Most people accord legal authorities, including the police and the judiciary, the presumption of integrity, competence, and legitimacy, and as a consequence are likely to voluntarily cooperate and comply with them in their official capacities. ${ }^{355}$ By contrast, anomists treat legal authorities just as they do legal obligations: not as inherently worthy of respect or obedience but rather as potential constraints to be factored into calculations of how best to pursue self-interest.

\section{iii. Amoralism}

"Amoralism" refers to an absence of absolutism exercised in the evaluation and judgment of character, conduct, ethics, and values. Its converse, moralism, can be, but is not necessarily, religiously motivated. Several scholars suggest that moral judgments are more consequential than the perceived certainty or threat of punishment in decisionmaking with respect to compliance with legal obligations, ${ }^{356}$ and at least one argues that "morality [is] the most important factor in shaping law-related behavior., ${ }^{357}$ As Tyler explains,

$[\mathrm{P}]$ eople $\mathrm{d}[\mathrm{o}]$ not simply act in pursuit of gains. Rather, their own personal sense of right and wrong influence[s] their behavior. Most people give little or no consideration to the possible gains and losses

\footnotetext{
${ }^{348}$ TYLER, supra note 139 , at 3.

${ }^{349}$ See ROBERT DALLEK, THE AMERICAN STYLE OF FOREIGN POLICY: CULTURAL POLITICS AND FOREIGN AFFAIRS xi (indicating that part of the "American style of foreign policy" is a reverence for the rule of law).

${ }^{350}$ At the very least, it can safely be stated that for a great many people, and in all likelihood a substantial majority across demographic and geographical boundaries, law-following is a decided preference. See Kenneth G. Dau-Schmidt, An Economic Analysis of the Criminal Law as a Preference-Shaping Policy, 1990 DUKE L.J. 1 (1990).

${ }^{351}$ See G.R. Boynton, S.C. Patterson, \& R. Hedlund, The Structure of Public Support for Legislative Institutions, 12 MIDWEST J. POL. SCI. 163 (1968) (reporting that over seventy percent of respondents agree with the statement that law "must always be obeyed"); H.R. Rodgers \& E. Lewis, Political Support and Compliance Attitudes, 2 AM. POL. Q. 61 (1974) (demonstrating strong and widespread tendency toward obedience to legal rules); TYLER, supra note 139, at 44-45 (reporting that almost all respondents surveyed indicated that it is "very wrong" to break the law under almost all circumstances, including where the substantive obligations are contrary to personal conceptions of morality or justice); HERBERT C. KELMAN \& V. LEE HAMILTON, CRIMES OF OBEDIENCE 269 (1989) (same).

${ }^{352}$ See CHAYES \& CHAYES, supra note 71, at 117 (recognizing that for some individuals law has no normative value).

${ }^{353}$ See TYLER, supra note 139, at 47 (reporting that older respondents are more likely to view law as inherently worthy of respect than younger respondents and that level of education is inversely related to respect for the law).

${ }^{354}$ See, e.g., DANIEL JONAH GOLDHAGEN, HITLER'S WILLING EXECUTIONERS: ORDINARY GERMANS AND THE HOLOCAUST (1997) (suggesting that the willingness of the German population to contribute to the Holocaust is in large measure a function of the deeply-rooted German cultural attitude favoring compliance with and respect for authority).

${ }_{355}$ See TYLER, supra note 139, at 38-39, 47 (reporting that most respondents surveyed respect, feel proud of, and believe in the honesty and integrity of law enforcement and judicial officers); $i d$. at 45 (reporting that most respondents surveyed agreed that legal authorities should be obeyed and respected, and that these values should be transmitted to children, even if individual litigants believe legal authorities to be incorrect in their judgments).

${ }^{356}$ See, e.g., Grasmick \& Bursik, supra note_, at 837; TYLER, supra note 139, at 36-45.

${ }^{357}$ TOM R. TYLER ET AL., SOCIAL JUSTICE IN A DIVERSE SOCIETY 103 (1997).
} 
associated with illegal behavior. Instead, they simply engage in the behavior that they think is morally right. $^{358}$

Although morality can undermine compliance with law where the specific rules in question are perceived as morally illegitimate, most people regard compliance as a moral duty and consider non-compliance morally unjustifiable. ${ }^{359}$ Moreover, many individuals consider the moral evil occasioned by noncompliance to be greater than the evil of obeying a law with which they disagree, and consequently comply on moral grounds. ${ }^{360}$ The ideal-typic anomist, however, accords no moral virtue to compliance and is agnostic, and thus amoral, with respect to right and wrong.

\section{iv. Ignorance of Law}

"Ignorance of law" is the absence of formal legal education. Those with legal training may be more likely than those untutored in the law to regard legal obligations as significant in relation to other commitments. ${ }^{361}$ Although legal training "does not assure that [decisionmakers trained in the law] will cast their votes for law observance, . . . some knowledge of the law, some appreciation of its significance, and some attitudes and habits of respect for the law find a place in the process of decision. ${ }^{, 362}$ Moreover, although most decisionmakers may know little about law, ${ }^{363}$ legal knowledge is an important determinant of compliance: the more a decisionmaker understands his legal obligations, the more likely s/he will be to comply. ${ }^{364}$ Accordingly, the anomist scores high on an index of ignorance of the law.

\section{v. Ignorance of IHL}

"Ignorance of IHL" refers to the absence of legal training in the IHL issue-area. As with the subconstruct "ignorance of law," knowledge of IHL is a determinant of compliance with IHL, and the less a decisionmaker knows about IHL the less likely s/he is to comply with the regime.

vi. summary, operationalization, and intercorrelations

While the pure ideal-typic anomist may exist only in theory, s/he is ignorant of the law, regards compliance with legal rules and authorities in purely instrumental terms, and complies only where it serves self-interests: morality does not factor into the analysis.

\section{c. Hostility}

"Hostility" cconsists of ten subconstructs—distrust, narcissism, cynicism, misanthropy, ethnocentrism, hostility, Machiavellianism, lack of empathy, selfishness, and anti-internationalism — that tap a set of intercorrelated beliefs, values, images, and attitudes regarding human relationships. The idealtypic hostile scores high, indicating the presence of the subconstruct in his or her personality profile to an extent significantly greater than the average person, on each subconstruct.

\footnotetext{
${ }^{358} I d$. at 116.

${ }^{359}$ See JANIS \& MANN, supra note 292, at 27 (describing use by many decisionmakers of a "simple moral precept" to make decisions); TYLER, supra note 139, at 38-39 (reporting that most people consider violation of law to be morally wrong).

${ }^{360}$ See HERSCH LAUTERPACHT, THE BASIS OF OBLIGATION 66 (1959) (“[I]f we ask why we ought to obey rules of law simply because they are rules of law, the answer is that there is a rule of morality of which that is the content. We obey not necessarily because we think that the law is right, but because we think it right to obey the law.")

${ }^{361}$ See Ratner, supra note 13, at 662-65 (suggesting the degree of legal training is significant to prioritization of legal obligations relative to other obligations).

${ }^{362}$ HENKIN, supra note 6, at 65-66.

${ }^{363}$ See BYERS \& NOLTE, supra note 18, at 104 (ascribing ignorance of international law to most decisionmakers).

${ }^{364}$ See Joyner, supra note 304, at 334 ("If . . . decision-makers know what the law is, then they can fashion policy to conform to the expectations of other governments.").
} 


\section{i. Distrust}

"Distrust" refers to a belief in the inherent lack of goodness in human beings; individuals with a high degree of distrust have misgivings about the intentions and activities of others and are wary of other actors. ${ }^{365}$ Individuals with a high degree of distrust are more likely than those who are less distrusting, or more idealistic, ${ }^{366}$ to overperceive, and overreact, to threats. ${ }^{367}$ The most distrustful decisionmakers can be termed "paranoid," defined as intensely suspicious of others, convinced that others are scheming to cause them harm or impose their will, and prone to see enemies in everyone despite contradictory evidence. ${ }^{368}$ Paranoids tend to resort unnecessarily to forceful measures in response to perceived threats. ${ }^{369}$ Distrust intercorrelates with cynicism and hostility.

ii. Narcissism

"Narcissism" is the belief that one is endowed with great power, physical appeal, and the right to exploit and dominate others. ${ }^{370}$ Narcissists crave attention and constant reassurance and need to be perceived as powerful, appealing, and worthy of love and admiration. ${ }^{371}$ Narcissists are preoccupied with grandiose fantasies of wealth and fame, devoid of conscience or remorse, and willing to use whatever force is necessary to achieve goals. ${ }^{372}$ The most malignant of narcissists, or "antisocial personalities," are often reckless, sadistic, suicidal, and prone to depression. ${ }^{373}$

Narcissists are self-absorbed and are not possessed of deeply-held beliefs about the external world: their images of others are flexible, and other actors are of value or of concern to the narcissist only to the extent that they enhance his personal self-interest or present him in a good light. For the narcissist, what is good for himself is good for his state, and foreign policy issues are reducible to considerations of how particular decisions advance his concept of self. ${ }^{374}$ Because they are detached from reality to the extent of their self-absorption, narcissists are systematically inclined to overestimate their own capabilities and fail to recognize external constraints. ${ }^{375}$ Narcissism is positively intercorrelated with dogmatism, isolationism, and disrespect of law and legal authorities. ${ }^{376}$

$$
\text { iii. Cynicism }
$$

\footnotetext{
${ }^{365}$ STEINBRUNER, supra note 286, at 47.

${ }^{366}$ See George, supra note 262, at 202 (characterizing individuals who are trusting of others and believe in a "fundamental harmony of interests among peoples and nations" as "idealists"); see also JOHN C. FARRELL \& ASA P. SMITH, EDS., IMAGE AND REALITY IN WORLD POLITICS 16 (1967) (dividing decisionmakers into those who believe in the "inherent good faith" of others and those who are convinced of the "inherent bad faith" of humanity).

${ }^{367}$ See Michele G. Alexander, Marilynn B. Brewer, \& Richard K. Hermann, Images and Affect: A Functional Analysis of Outgroup Stereotypes, 77 J. PERS. SOC. PSYCH. 78, 80 (1999).

${ }^{368}$ See JERROLD POST \& R. ROBINS, POLITICAL PARANOIA: THE PSYCHOPOLITICS OF HATRED 7-12 (defining the paranoid personality).

${ }^{369}$ See J. DAVIS, THREATS AND PROMISES 41 (2000); SINGER \& HUDSON, supra note 193, at 88.

${ }^{370}$ See VERTZBERGER, supra note 248 at 174 (defining the narcissistic personality).

${ }^{371}$ See LASSWELL, supra note 238, at 262.

${ }^{372}$ POST, supra note 232, at 83-84.

${ }^{373}$ See W. JOHN LIVESLEY, ED., THE DIAGNOSTIC AND STATISTICAL MANUAL IV-REVISED 117 (1995).

${ }^{374}$ POST, supra note 232, at 87. Famous historical narcissists include Josef Stalin and Adolf Hitler, both of whom portrayed themselves as the auteurs of new political-economic orders. See Betty Glad, Why Tyrants Go Too Far: Malignant Narcissism and Absolute Power, 23 POL. PSYCH. 1, 5 (2002).

${ }^{375} I d$. at 33-34.

${ }^{376}$ See POST, supra note 232, at 85 (dogmatism); DSM-IV, supra note 373, at 117 (isolationism, respect for law and legal authorities).
} 
"Cynicism" is the belief that others are self-interested, insincere, and motivated primarily by material considerations, and the corresponding negative general image of humanity. ${ }^{377}$ Cynics expect the worst of others, and consequently are more likely to perceive threats than are individuals who view others as inherently cooperative, sincere, and motivated by norms. ${ }^{378}$

iv. Misanthropy

"Misanthropy" is a generalized dislike, and even hatred, of human beings. Simply put, misanthropes are antisocial, do not seek or enjoy the company of others, and actively seek to avoid or, in the alternative, to cause harm to other persons.

\section{v. Ethnocentrism}

"Ethnocentrism" is the belief that one's own ethnic, racial, or cultural group is superior to others and the attitude that association with persons of one's own ethnic, racial, or cultural group is preferable to association with members of other groups. ${ }^{379}$ Whether ethnocentrism has biological determinants or is simply a social construction is as yet uncertain. ${ }^{380}$ Whatever the cause, ethnocentrics project their preference for members of their own groupings onto the international system, and the degree of their cooperation with other states is, in some measure, determined by the degree of ethnic similarity or dissimilarity. ${ }^{381}$ Accordingly, justification for hostility is readily available to the ethnocentric who identifies ethnic dissimilarities between his own state and the target of his decisionmaking and attributes hostile intent to the target on the basis of these dissimilarities $;{ }^{382}$ greater vigilance is thus required to protect against this threat. ${ }^{383}$ Taken to extremes, ethnocentrism creates a culture of fear that rationalizes infliction of harm on out-groups to preempt the threat they pose. ${ }^{384}$ Ethnocentrism is positively intercorrelated with aggression, distrust ${ }^{385}$ and selfishness. ${ }^{386}$

\section{vi. Hostility}

"Hostility" is the perception that others hold highly negative images of, and have strongly negative intentions toward, one's self, group, or state. ${ }^{387}$ In some sense, hostility is the corollary of distrust in that it is an assessment of the degree of distrust operant in the calculus of external actors. The greater the perception of hostility, the less likely a decisionmaker will be to recognize disconfirming

\footnotetext{
${ }^{377}$ See R.E. Agger, M.N. Goldstein, \& S.A. Pearl, Political Cynicism: Measurement and Meaning, 23 J. POL. 477 (1961).

${ }^{378}$ HERMANN, supra note 336 , at 339 .

${ }^{379}$ See WILLIAM GRAHAM SUMNER, FOLKWAYS 12-13 (1906) (describing ethnocentrism as in-group tendency to "nourish its own pride and vanity, boast[] itself superior, exalt[] its own divinities, and look[] with contempt on outsiders.").

${ }^{380}$ For a discussion of ongoing research, see E.J. Gil-White, Are Ethnic Groups Biological "Species" to the Human Brain?: Essentialism in Our Cognition of Some Social Categories, 42 CURR. ANTHRO. 515 (2001).

${ }^{381}$ CHITTICK, supra note 229 , at 52 (tracing congruence between patterns of interaction in international relations and the patterns of attitudes regarding relevant ethnicities held by groups in various states).

${ }_{382}$ See Alexander et al., supra note 368, at 78-79 (describing resort to imagery derived from ethnic differences to justify interstate hostility); VOLKAN, supra note 316, at 119-21 (describing the process whereby ethnic or cultural difference is translated into enemy status in the minds of ethnocentric decisionmakers); SEARS ET AL., supra note 78, at 585 ("Symbolic threats arise from intergroup differences in basic differences[.]").

${ }^{383}$ See POST, supra note 232, at 200 (linking ethnocentrism and hypervigilance in foreign policy decisionmaking).

${ }^{384}$ See, e.g., Meredith W. Watts, Political Xenophobia in the Transition from Socialism: Threat, Racism, and Ideology Among East German Youth, 17 POL. PSYCH. 97, 119 (1996); SANDOLE, supra note 322, at 111 (linking ethnocentrism and externalization of aggression to out-groups); SINGER \& HUDSON, supra note 193, at 88 (same).

${ }^{385}$ See OFFERMAN-ZUCKERBERG, supra note 288, at 277 (aggression); POST, supra note 232, at 200 (distrust).

${ }^{386}$ SEARS ET AL., supra note 78, at 161 (identifying the opposite of ethnocentrism as "altruism").

${ }^{387}$ FARRELL \& SMITH, supra note 367, at 16.
} 
information ${ }^{388}$ and the more likely s/he will be to perceive external actors as aggressive, ${ }^{389}$ to escalate threats, ${ }^{390}$ and to meet the perception of aggression with force. ${ }^{391}$ Although heightened perceptions of hostility may correspond to political realities, particularly in the context of long-standing military confrontations wherein the citizens of belligerents become sensitized to expect hostility from their overt adversaries ${ }^{392}$ most individuals can distinguish "immediate and genuinely hostile out-groups" without "detecting hostility from the entire world." ${ }^{, 393}$ Clinically hostile individuals, however, are caught in a "siege mentality" that persists independently of reason. ${ }^{394}$ Hostility is intercorrelated with distrust, aggression, and patriotism. ${ }^{395}$

vii. Machiavellianism

"Machiavellianism" is the set of values that denies the relevance of morality in politics and asserts that deception, stealth, and manipulation are justified in pursuing and maintaining power and selfinterest. ${ }^{396}$ The Machiavellian is "completely ruthless in the struggle for power," devious, and utterly amoral in the pursuit of self-interest. ${ }^{397}$ Neither norms, nor laws, stand in his way. ${ }^{398}$ Machiavellianism is positively intercorrelated with hostility, ethnocentrism, narcissism, distrust, amoralism, selfishness, and lack of empathy.

\section{viii. Lack of Empathy}

Empathy is defined as the "projection of one's own personality into the personality of another in order to understand him better" and the "ability to share in another's emotions or feelings." 399 It is the trait that disposes an individual to seek out and understand the views, interests, and values of other persons and groups. ${ }^{400}$ Empathy may ameliorate self-interest and guide decisionmakers toward considering the consequences of their decisions for others; through its effects, empathy may dampen the frequency and intensity of international conflict. ${ }^{401}$ By contrast, "lack of empathy" is the incapacity to form accurate perceptions and judgments of others and inflexibility in adapting to and learning from

\footnotetext{
${ }^{388}$ FALKOWSKI, supra note, at 295.

${ }^{389}$ See SEARS ET AL., supra note 78, at 265 (theorizing that high levels of hostility correlate with the presumption of the "inherent bad faith" and aggressiveness of other actors and the tendency to cast others as "enemies").

${ }^{390}$ See POST \& ROBINS, supra note 369, at 26 (explaining that some individuals "lack the basic social skill of reacting to a provocation by either ignoring it or meeting the level of provocation" and instead "meet hostility with greater hostility").

${ }^{391}$ See, e.g., Avi Shlaim, Failures in National Intelligence Estimates: The Case of the Yom Kippur War, 28 WORLD POL. 348 (1976) (correlating hostility with perception of threats); Dan Jacobson \& Daniel Bar-Tal, Structure of Security Beliefs Among Israeli Students, 16 POL. PSYCH. 567, 580 (1995) (correlating hostility with the use of force in foreign policy); DAVIS, supra note_, at 5 (stating that the tendency of decisionmakers to adopt aggressive foreign policies is reinforced by the belief that their state is "surrounded by a hostile environment").

${ }^{392}$ See Jacobson \& Bar-Tal, supra note 393, at 585 (describing the preoccupation with security that has become the "master symbol in the Israeli-Jewish ethos" and a "kind of "religion"” in response to millennia of military conflict with numerous surrounding states, peoples, and terrorist groups).

${ }^{393}$ POST \& ROBINS, supra note 369 , at 57.

${ }^{394}$ See McGOWAN \& SHAPIRO, supra note 240 at 53-60 (postulating correlation between irrational perceptions of hostility and violent foreign policy decisionmaking).

${ }^{395}$ See POST \& ROBINS, supra note 369, at 57 (distrust and aggression); Alexander Thompson, Applying Rational Choice Theory to International Law: The Promise and Pitfalls, 31 J. LEG. STUD. 285 (2002) (patriotism).

${ }^{396}$ See generally NICCOLO MACHIAVELLI, THE PRINCE (W.K. Marriott transl. 1916) (1505).

${ }^{397}$ See Glad, supra note 375, at 33.

${ }^{398}$ See RAYMOND ARON, POLITICS AND HISTORY (M.B. Conant transl 1995) (defining machiavellianism as the sacrifice of morality to expedience).

${ }^{399}$ WEBSTERS NEW WORLD DICTIONARY 458 ( $2^{\text {nd }}$ College Ed. 1984).

${ }^{400}$ SEARS ET AL., supra note 78, at 266.

${ }^{401}$ See generally M.L. Hoffman, Toward a Theory of Empathic Arousal and Development 227-56, in M. Lewis \& L.A.

Rosenblum, eds., The Development of Affect (1978).
} 
incoming stimuli. ${ }^{402}$ Individuals who lack empathy are more likely to dehumanize their adversaries and to legitimate conflictual policies in regard to their opponents. ${ }^{403}$ Lack of empathy is positively intercorrelated with aggression ${ }^{404}$ distrust, and hostility. ${ }^{405}$

\section{ix. Selfishness}

Altruism is the value placed upon aiding others despite high risks and high costs and despite the absence of the expectation of an external reward; altruism is arguably the polar opposite of selfishness. ${ }^{406}$ The paradigmatic example is the self-sacrifice of the soldier who saves a number of his comrades from certain death by throwing himself upon a grenade in their midst, absorbing the blow but ensuring his own demise. "Selfishness" is the antithesis of altruism and is positively intercorrelated with lack of empathy, low self-esteem, ethnocentrism, and authoritarianism. ${ }^{408}$

\section{x. Anti-internationalism}

"Ant-internationalism" describes an orientation toward the global environment that shuns cooperative participation in a wide range of international affairs, including educational, sporting, cultural, social, economic, and security arrangements. Anti-internationalism is, to some extent, the corollary of hypernationalism: anti-internationalists view unfavorably the creation and maintenance of transnational networks to enhance international contacts and cooperation, and, given a choice between national sovereignty and transnational regulation, are disposed to prefer the former. ${ }^{409}$ Anti-internationalism is positively intercorrelated with distrust, hostility, aggression, and lack of empathy. ${ }^{410}$

\section{xi. Hostility: Summary and Operationalization}

The ideal-typic hostile is a self-absorbed, delusional, and amoral individual who is deeply distrustful and suspicious of the intentions of others and sees threats lurking everywhere. S/he bears an animus toward humanity that is mitigated only in regard to persons of his or her own racial, ethnic, or cultural group, and s/he is prepared to do anything and everything, including use aggressive force, to defeat the omnipresent threats posed by outgroups about whom s/he knows or cares little.

\section{d. Adventurism}

“Adventurism"consists of seven subconstructs—risk tolerance, internal locus of control, impulsivity, anxiety, optimism, stress, and maleness - that tap a set of intercorrelated beliefs, values, images, attitudes, and biological predispositions regarding the tolerance of uncertainty and the role of

\footnotetext{
${ }^{402}$ Lee F. Anderson, A Comparison of Simulation, Case Studies, and Problems: Papers in Teaching Decision-Making 78 (doctoral dissertation, Northwestern University, 1964).

${ }^{403}$ VOLKAN, supra note 316 , at 121 (stating that "empathy must be destroyed in order to dehumanize the enemy" and to denature the moral consequences of directing aggression toward them).

${ }^{404}$ ETHEREDGE, supra note 209, at 53.

${ }^{405}$ ELMS, supra note 274, at 130.

${ }^{406}$ See generally HOWARD MARGOLIS, SELFISHNESS, ALTRUISM, AND RATIONALITY: A THEORY OF SOCIAL CHOICE (1984) (comparing and contrasting altruism and selfishness).

${ }^{407}$ See William H. Riker, The Political Psychology of Rational Choice Theory, 16 POL. PSYCH. 23, 38 (1995) (examining citations of Congressional Medal of Honor recipients as evidence of the expression of altruism).

${ }^{408}$ OFFERMAN-ZUCKERBERG, supra note 299, at 291-96 (empathy, self-esteem); SEARS ET AL., supra note 78 , at 161 (ethnocentrism, authoritarianism)

${ }^{409}$ See EUGENE R. WITTKOPF, COOPERATIVE AND MILITANT INTERNATIONALISM (1990).

${ }^{410}$ See Howard P. Smith \& Ellen Weber Rosen, Some Psychological Correlates of Worldmindedness and Authoritarianism, $26 \mathrm{~J}$. PERSONALITY 170 (1958) (measuring correlates of internationalism (described as "worldmindedness")).
} 
chance. The ideal-typic adventurist scores high, indicating the presence in his or her personality profile to an extent significantly greater than the average person, on each subconstruct.

i. Tolerance of Risk

Uncertainty, or risk, is an immutable characteristic of the universe, ${ }^{411}$ and individuals vary in their tolerance for it. ${ }^{412}$ Several theories posit that certain individuals are cognitively disposed to greater tolerance of risk than are others, ${ }^{413}$ while other theories focus on the decisionmaking context and suggest that high-stakes decision problems, particularly those that arise during armed conflicts, are most likely to promote risk-taking behaviors. ${ }^{414}$ "Tolerance of risk" is a measurement of the degree to which an individual will routinely choose courses of action that, although they may offer the prospect of gains, carry with them significant possibilities of injury, damage, harm, or loss. Risk-tolerant individuals are more likely to take chances and expose themselves and their states to danger in the pursuit of absolute and relative gains than are risk-averse individuals, who tend to seek the decision that satisfies minimal policy objectives with the least possibility for loss. ${ }^{415}$ The most risk-tolerant individuals are inclined to forgo easy gains in pursuit of quixotic objectives. ${ }^{416}$ Tolerance of risk is positively intercorrelated with impulsivity and internal locus of control. ${ }^{417}$

\section{ii. Internal Locus of Control}

"Internal locus of control" refers to the belief that one is capable of exerting a positive influence over the external world significant enough to bring about a particular future result chosen by and favorable to the individual. For individuals whose locus of control is external to themselves, the belief that no matter what they do their destiny is preordained can lead to decisional paralysis and mental inactivity. In contrast, individuals with an internal locus of control attribute causality of and responsibility for their behavior to themselves rather than to the external world. ${ }^{418}$ Will, and not Fate, determines their future. Consequently, decisionmakers with an internal locus of control are more likely than those with an internal locus of control to challenge environmental constraints and "push the limits of what is possible" and less likely to remain passive or accept compromise solutions. ${ }^{419}$

$$
\text { iii. Impulsivity }
$$

\footnotetext{
${ }^{411}$ See Yaacov Y.I. Vertzberger, Rethinking and Reconceptualizing Risk in Foreign Policy Deicison-Making: A Sociocognitive Approach, 16 POL. PSYCH 347, 349 (1995) (defining "uncertainty" as the condition that pertains when a deicisonmaker "has neither the knowledge of nor the objective probabilities of distribution of the outcomes associated with an event" and contrasting this with "risk," defined as the objective and informed measurement of the probability of an event). The distinction is not theoretically significant for purposes of this study and shall thus be conflated.

${ }^{412} I d$. at 152 (describing risk-propensity as "idiosyncratic" and variable across range of decisionmakers).

${ }^{413}$ See, e.g., SEARS ET AL., supra note 78 (describing prospect theory, which postulates that certain decisionmakers will accept high risk to avoid losses); FALKOWSKI, supra note 242, at 103 (theorizing that "optimizers" are more likely to choose options with greater payoffs but higher risks than are "satisficers," who seek low payoffs and are risk averse)

${ }_{414}^{414}$ See, e.g., Vertzberger, supra note 412 , at 363.

${ }^{415} I d$. at 368-69.

${ }^{416}$ See ROSE McDERMOTT, RISK-TAKING IN INTERNATIONAL POLITICS: PROSPECT THEORY IN AMERICAN FOREIGN POLICY 2 (1998) (developing a comprehensive theory of risk in foreign policy decisionmaking).

${ }^{417}$ Barry O'Neill, Risk Aversion in International Relations Theory, 45 INT’L STUD. Q. 617, 627 (2001) (presenting correlates of risk-tolerance).

${ }^{418}$ MAGNUSSON, supra note 241, at 186-88 (contrasting internal and external locus of control and associated beliefs).

${ }^{419}$ POST, supra note 232, at 187-88.
} 
"Impulsivity" is the trait characterized by the inability to self-modulate sensory input, inhibit sensation-seeking behavior, or consider the consequences of actions. ${ }^{420}$ Impulsivity is negatively intercorrelated with intraversion. ${ }^{421}$

iv. Anxiety

"Anxiety" is the trait in which an individual is particularly prone to evaluate stimuli as dangerous and to experience concomitant feelings of worry, distress, and panic. Anxious individuals are more likely than non-anxious individuals to perceive and respond to threats and to have greater difficulty in relaxing after stimulation. $^{422}$

\section{v. Optimism}

"Optimism" is the belief that the future will generally produce preferred outcomes and that it is prudent to expect the best of people, things, and events. Optimists are disposed to underestimate risk and overestimate their own capabilities. ${ }^{423}$ Optimism is positively intercorrelated with tolerance of risk and internal locus of control. ${ }^{424}$

vi. Stress

"Stress" is the aggregate of the physical and emotional responses produced by an individual in unconscious adaptation to environmental stimuli. ${ }^{425}$ Individuals vary in their perceptions of stress and in their ability to preserve cognitive functioning as stressors mount, yet all experience degradation in their ability to generate alternatives and choose optimal courses of action in situations that threaten core values and interests. ${ }^{426}$ The more pronounced the stress experienced by a decisionmaker, the less likely s/he is to generate alternatives and the more likely s/he is to elect high-risk options. ${ }^{427}$ Stres is positively intercorrelated with aggression, cognitive simplicty, and tolerance of risk. ${ }^{428}$

vii. Male Sex

Some aspects of personality relevant to decisionmaking are likely sex-specific. Although sexrole differences may be constructs of socialization rather than biologically determined, ${ }^{429}$ men are significantly and consistently more likely than women to be competitive, aggressive, ethnocentric, Machiavellian, distrustful, ambitious, and lack empathy. ${ }^{430}$

\footnotetext{
${ }^{420}$ See H.J. EYSENCK \& S.B.G. EYSENCK, PERSONALITY STRUCTURE AND MEASUREMENT (1967).

${ }^{421}$ MAGNUSSON, supra note 241, at 132.

${ }^{422}$ See generally C.D. SPIELBERGER, ANXIETY AND BEHAVIOR (1966).

${ }^{423}$ See, e.g., ROBERTA WOHLSTETTER, PEARL HARBOR: WARNING AND DECISION 348-401 (discussing the role optimism may have played in contributing to U.S. underestimation of the Japanese threat in 1941).

${ }^{424}$ FALKOWSKI, supra note 242, at 103 (correlating optimism with selection of low-risk alternatives).

${ }^{425}$ See A.J. MAULE \& O. SVENSON, TIME PRESSURE AND STRESS IN HUMAN JUDGMENT AND DECISION MAKING 1-2 (2003) (defining stress).

${ }^{426}$ See generally id.

${ }^{427} I d$.

${ }^{428}$ HERMANN, supra note 336, at 353 (aggression); ALAN DOWTY, MIDDLE EAST CRISES: U.S. DECISION-MAKING IN 1958, 1970, AND 1973 12-18 (1984) (cognitive simplicity); McDERMOTT, supra note 417, at 4 (tolerance of risk).

${ }^{429}$ But see OFFERMAN-ZUCKERBERG, supra note 299, at 384 (suggesting that women may be, by virtue of their biologically determined function as "givers of life," more invested in nurturing offspring, more committed to preserving peace in order to protect those offspring, and thus more likely to "help bring about human harmony on earth"); J. Sidanius \& B. Ekehammar, Sex, Political Party Preference and Higher-Order Dimensions of Socio-Political Ideology, 115 J. PSYCH. 233 (1983) (attributing sex-based personality difference to reproductive strategies and investment levels in offspring).

${ }^{430}$ See D'Agostino, supra note 325, at 280 (discussing nature-nurture debate in context of sex-specific beliefs, values, and images postulated as correlates of militarism). For a discussion of differences real and perceived between men and women in the theory and practice of international relations, as well as a series of explanations for these differences, see MARYSIA ZALEWSKI \&
} JANE PARPART, EDS., THE “MAN” QUESTION IN INTERNATIONAL RELATIONS (1998). 
viii. Summary and Operationalization: Adventurism

The ideal-typic adventurist is an impulsive gambler who is so optimistic that he can assert his will upon events that he will risk all for the sheer thrill of pursuing the prospect of a victory no matter how small or unlikely. He resolves the tremendous anxiety and stress that accompanies his risky behavior by trusting blindly and, in effect, rolling the dice.

\section{Dependent Variables: Decisions and Judgments Regarding Anticipatory Self-Defense}

The PT model of IHL compliance ["PT-IHLC"] regards the presence or absence of the personality constructs of militarism, anomism, hostility, and adventurism in the personalities of HDs as independent variables ["IVs"] that determine state compliance with IHL and treats these decisions and the resulting judgments of other actors as the dependent variables ["DVs"]. To test the strength of the causative relationship at this primary stage of theory development, a constituent sub-regime of IHL-that governing war initiation-has been selected as the initial building block upon which the more general study of compliance decisions throughout the range of IHL issues, including the selection of methods and the choice of means, will be subsequently built. ${ }^{431}$ Specifically, the DVs in the present study concern compliance with that aspect of the subregime of IHL governing the resort to war prior to the occurrence of an armed attack, termed "anticipatory self-defense" ["ASD"].

DVs include the following:

(1) whether ASD is considered as an option;

(2) whether ASD is selected;

(3) whether attempt is made to defend an exercise of ASD;

(4) whether an exercise of ASD is defended on legal grounds;

(5) whether other actors regard an exercise of ASD as lawful at the time of its exercise;

(6) whether other actors regard an exercise of ASD as legitimate at the time of its exercise;

(7) whether the state engaging in ASD is subject to legal sanctions;

(8) whether other actors regard an exercise of ASD as lawful and/or legitimate in retrospect;

(9) whether the HD who ordered his/her state to engage in or refrain from ASD would make the same decision if offered the opportunity to decide again; and

(10) whether an exercise of ASD can fairly be said to have contributed to world order.

a. introduction: ASD

For most of history the sovereign prerogative of states to resort to armed conflict was immune from regulation, ${ }^{432}$ and well into the $20^{\text {th }}$ century states exercised the right to engage in war in response to a host of perceived offenses, to collect debts, and to acquire territory. ${ }^{433}$ However, the Covenant of the League of Nations ${ }^{434}$ and the Kellogg-Briand Pact of $1928^{435}$ advanced the crystallization of an as yet

\footnotetext{
${ }^{431}$ See infra at pp._ (discussing plans for future research incorporating additional dependent variables).

${ }^{432}$ YORAM DINSTEIN, WAR, AGGRESSION, AND SELF-DEFENCE 176 (1994). As late as the $17^{\text {th }}$ century, jurists proclaimed that the right of self-defense extended to the vindication of any national claim. See D.P. O'CONNELL, INTERNATIONAL LAW 339 (1965).

${ }^{433}$ See 6 HACKWORTH, DIGEST OF INTERNATIONAL LAW 152-55 (1943) (discussing legal bases for state practice in employing force in early $20^{\text {th }}$ century).

${ }^{434}$ See Covenant of the League of Nations, Treaty of Versailles, Jun. 20, 1919, Part I, 225 Consol. T.S. 189, at Art. 12

(committing states-parties not to resort to war against other states-parties "within three months" after an unsuccessful attempt to arbitrate the dispute).
} 
inchoate international customary prohibition ${ }^{436}$ on "aggression," commonly defined as the use of armed force against the territorial integrity or political independence of another state. ${ }^{437}$ In turn, the emerging jus ad bellum ${ }^{438}$ found expression in 1945 in the Charter of the United Nations, ${ }^{439}$ as well as application at Nuremburg, ${ }^{440}$ and quickly acquired the status of a peremptory norm. ${ }^{441}$ Article 2(4) of the Charter categorically proscribes "the threat or use of force against the territorial integrity or political independence of any state," ${ }^{442}$ and thus it is "well settled in modern international law that no nation may engage in aggression." ${ }^{443}$

Nevertheless, imposition of a sharp prohibition on aggression has not disabled the "inherent right" of states to self-defense. ${ }^{444}$ Although the UN Charter has had a transformative effect on the law governing the resort to force, ${ }^{445}$ states remain free under customary international law to use force "in conformity with the Charter." ${ }^{\circledR 46}$ Accordingly, states resort to armed self-help to defend their territory and political independence and protect their nationals and property abroad from threats of death or injury, ${ }^{447}$

\footnotetext{
${ }^{435}$ See Treaty Providing for Renunciation of War as an Instrument of National Policy ["Kellogg Briand Pact"], Aug. 28, 1928, 46 Stat. 2343, 94 L.N.T.S. 57, at Art. 1 ("condemn[ing] recourse to war for the solution of international controversies, and renounc[ing] it, as an instrument of national policy" in relations between states-parties).

${ }^{436}$ International law consists of treaty-based, as well as customary, sources of law. See Statute of the International Court of Justice, art. 38, 59 Stat. 1055 (1945) (enumerating sources of international law as treaties, custom, general principles, and the opinions of expert commentators). Customary international law evolves from the practice of states consistent with the subjective understanding that such practice is legally obligatory. North Sea Continental Shelf Cases (F.R.G. v. Denmark \& Netherlands), 1969 I.C.J. 4.

${ }^{437}$ The precise definition of "aggression" has bedeviled international lawyers for nearly a century. See Jonathan A. Bush, "The Supreme Crime” and its Origins: The Lost Legislative History of the Crime of Aggressive War, 102 COLUM. L. REV. 2324 (2002) (chronicling the history of attempts to define the term); JULIUS STONE, AGGRESSION AND WORLD ORDER 88 (suggesting it may be impossible to overcome politics and achieve a universal definition). In recent years a general definition of aggression has emerged that includes the elements of a military attack, not otherwise justified by international law, directed against the territory of another state. See Louis Rene Beres, After the Gulf War: Israel, Preemption, and Anticipatory SelfDefense, 13 HOUSTON J. INT'L L. 259, 263 n.5 (1991) (synthesizing various definitions).

${ }^{438}$ The strand of IHL known as the jus ad bellum governs the right to resort to armed force, whereas jus in bello governs the methods and means employed in war and specifies who and what are legitimate targets. See William J. Fenrick, Should Crimes Against Humanity Replace War Crimes?, 37 COLUM. J. TRANSNAT'L L. 767, 770 (1999) (differenting jus ad bellum from jus in bello).

${ }^{439}$ Charter of the United Nations, June 26, 1945, 59 Stat. 1031, TS 993, 3 Bevans 1153, entered into force Oct. 24, 1945, at Art. 2(4) ("All Members shall refrain in their international relations from the threat or use of force against the territorial integrity or the political independence of any state[.]").

${ }^{440}$ See 1 TRIAL MAJ. WAR CRIM. BEFORE INT'L MIL. TRIB 208, 218-22 (1946), reprinted at 41 AM. J. INT'L L. 205,207 (1947) ["Nuremburg Judgment"] (convicting defendants of conspiracy to wage "aggressive war").

${ }^{441}$ A norm of jus cogens "is a norm accepted and recognized by the international community of States as a whole as a norm from which no derogation is permitted and which can be modified only by a subsequent norm of general international law having the same character." Vienna Convention on the Law of Treaties, May 22, 1969, 8 I.L.M. 679, at Art. 53. The prohibition against aggression in international relations is widely regarded as having attained the status of a norm of jus cogens. See ARTHUR WARRS, 2 THE INTERNATIONAL LAW COMMISSION 1949-1998 741 (1999) ("the law of the Charter concerning the prohibition of the use of force in itself constitutes a conspicuous example of a rule in international law having the character of jus cogens."); Case Concerning Military and Paramilitary Activities in and around Nicaragua (Nicar. V. U.S.), 1986 I.C.J. at 100 (holding that the norms represented by Article 2(4) approach jus cogens status).

${ }^{442}$ UN Charter, supra note 440, at Art. 2(4).

${ }^{443}$ Jeffrey F. Addicott, Proposal for a New Executive Order Banning Assassination, 37 U. RICHMOND L. REV. 751,769 (2003).

444 "Self-defense" under international law may be defined as "a lawful use of force . . . under conditions prescribed by international law, in response to a previous unlawful use (or, at least, a threat) of force." DINSTEIN, supra note 433 , at 175.

${ }^{445}$ Scholars debate not whether the UN Charter has transformed the jus ad bellum but the degree to which it has done so. See Timothy Kearley, Regulation of Preventive and Preemptive Force in the United Nations Charter: A Search for Original Intent, WYOMING L. REV. 664, 665 (2003) (examining such debates).

${ }^{446}$ Legality of the Threat or Use of Nuclear Weapons, 1996 I.C.J. Rep.

${ }^{447}$ See Abraham D. Sofaer, Terrorism, the Law, and National Defense, 126 MIL. L. REV. 95, 99 (1989) (noting that states "have traditionally defended their military personnel, citizens, commerce, and property from attacks[.]"); Robert J. Beck \& Anthony Clark Arend, "Don't Tread on U.S.”: International Law and Forcible State Response to Terrorism, 12 WISC. INT'L L. J. 153, 153 (1994) ("No nation should be limited to using force to protect its citizens . . to situations in which they are within its boundaries.") Jordan W. Paust, Responding Lawfully to International Terrorism, WHITTIER L. REV. 711,729 (1986) (enumerating lawful bases for the use of force in self-defense).
} 
and they do so without impinging the territorial integrity or political independence of states that fail in their duty to protect aliens and alien property within their jurisdiction. ${ }^{448}$ Moreover, self-defense remains so intrinsic to the concept of sovereignty even in the Charter era that the right is likely "one that would be asserted by nations absent recognition in international law.",499

In fact, the Charter does not of its own force disable or impair the right to self-defense, nor is it clear that its framers intended that it do so. ${ }^{450}$ Article 2(4) prohibits only three specific applications of the threat or use of force: (1) where prejudicial to the territorial integrity of states; (2) contrary to the political independence of states; and (3) "in any other manner inconsistent with the Purposes of the United Nations. ${ }^{\circledR 451}$ In other words, a use of force not excluded by operation of Article 2(4) is theoretically permitted, and provided it cannot legitimately be construed as challenging either the territorial integrity or political independence of a state or as inconsistent with the primary purpose of the UN-the "maintenance of international peace and security, ${ }^{, 452}$ - it is arguably permissible. ${ }^{453}$ The use of force under such circumstances is arguably not inconsistent with the maintenance of international peace and security and not contrary to the Charter. Even more directly, Article 51 of the UN Charter recognizes ${ }^{454}$ the "inherent right" of a state subjected to aggression to engage in self-defense, and to receive the assistance of other states to that end. ${ }^{455}$

Precisely when the right to self-defend is transformed into a right to employ force is a hotly contested question. The customary international law doctrine of $\mathrm{ASD}^{456}$ holds that when a state is faced

\footnotetext{
${ }^{448}$ See JULIUS STONE, OF LAW AND NATIONS 24-26 (1974) (contrasting aggression in violation of Article 2(4) with defensive measures consistent with 2(4)); (characterizing use of force to protect nationals as lawful); MYERS MCDOUGAL \& W. MICHAEL REISMAN, INTERNATIONAL LAW IN CONTEMPORARY PERSPECTIVE 862-70 (1981) (same). Although literature review suggests that a majority of commentators now supports the right of a state to protect its nationals where necessary by armed force, for opposing views see, e.g., IAN BROWNLIE, INTERNATIONAL LAW AND THE USE OF FORCE BY STATES 301, (rejecting right of intervention to protect nationals); HENKIN, supra note 6, at 145 (same). ${ }^{449}$ Byard Q. Clemmons \& Gary D. Brown, Rethinking International Self-Defense: The United Nations' Emerging Role, NAV. L. REV. 217, 218 (1998). Indeed, as soon as the Kellogg-Briand Pact entered into force the U.S. and nearly a dozen other states moved to qualify the instrument with an authoritative interpretation providing that nothing in the text "restricts or impairs in any way the right of self-defense[,]" which is "inherent in every sovereign state and is implicit in every treaty." United States, Identic Notes, 1928, reprinted in 22 AM. J. INT'L L. Supp (1928).

${ }^{450}$ See TIMOTHY L.H. McCORMACK, SELF-DEFENSE IN INTERNATIONAL LAW 159 (1996) (concluding, after analysis of the legislative history, that the Charter was not intended to terminate customary international law with regard to the use of force or to draw all uses of force within the scope of Article 2(4)); BROWNLIE, supra note 449, at 271 (finding "no indication that the Charter language was meant to do anything other than reflect the current right of self-defense)); D. BOWETT SELFDEFENSE IN INTERNATIONAL LAW 188 (1956) (citing Doc. 1179, I/9(1), 6 U.N.C.I.O. Docs. 247 (1945)) (stating that under the UN Charter "self-defense remains admitted and unimpaired); Sean D. Magenis,Natural Law as the Customary International Law of Self-Defense, B.U. INT'L L.J. 413, 414 (2002) (Charter framers did not intend to limit the natural right of states to self-defense); George Walker, Anticipatory Collective Self-Defense in the Charter Era: What the Treaties Have Said, CORNELL INT'L L.J. 321, 351 (1998) (concluding the framers understood self-defense to be an inherent and inalienable right); Thomas Mallison \& Sally Mallison, The Israeli Aerial Attack of June 7, 1981, Upon the Iraqi Nuclear Reactor: Aggression or Self-Defense, 15 VAND. J. TRANSNAT'L L. 417, 420 (1982) (concluding from its drafting history that the Charter incorporates in toto the inherent right of self-defense ex ante in customary law).

${ }^{451}$ UN Charter, supra note 440, at Art. 2(4).

${ }^{452} I d$. at Art. 1(1).

${ }^{453}$ See Michael N. Schmitt, Preemptive Strategies in International Law, MICH. J. INT'L L. 513, 521-22 (same); but see Rex J. Zedalis, On the Lawfulness of Forceful Remedies for Violations of Arms Control Agreements: "Star Wars" and Other Glimpses of the Future, N.Y.U. J. INT'L L. \& POL. 73, 90-92 (1985) (conducting detailed exegesis of the travaux preparatoires of the UN Charter to reach the conclusion that "Article 2(4) was not intended to permit force to be used even when not inconsistent with the purposes of the United Nations.").

${ }^{454}$ Article 51 is not an affirmative grant but is rather the recognition of an inherent right of self-defense. See Walker, supra note 451, at 351-52 (clarifying status of the right to self-defense in the Charter as a recognized, and not a conferred, right).

${ }^{455}$ See UN Charter, supra note 440, at Art. 51 ("Nothing in the present Charter shall impair the inherent right of individual or collective self-defense if an armed attack occurs against a Member of the United Nations[.]").

${ }^{456}$ ASD is sometimes referred to as "preemptive self-defense." See, e.g., Miriam Sapiro, Iraq: The Shifting Sands of Preemptive Self-Defense, 97 AM. J. INT’L L. 599, 600 (2003 (equating the terms).
} 
with an imminent threat of armed attack it may lawfully resort to proportional acts of defensive armed force to preempt the attack before it is inflicted. ${ }^{457}$ The question remains unresolved whether the transformations wrought by Charter include impairment of the right of states to engage in ASD even under the narrowly delimited circumstances of necessity resulting from an imminent threat of sufficient magnitude. ${ }^{458}$ For restrictivists, ${ }^{459}$ ASD is a dangerous warrant for manipulative, self-serving states to engage in prima facie illegal aggression while cloaking their actions under the guise of legal legitimacy. ${ }^{460}$ For restrictivists Article 51 is unambiguous in its requirement that an armed attack occur prior to the lawful exercise of self-defense. For the pragmatists, however, to read the Charter hypertechnically to require that a state assume the posture of a "sitting duck" and submit to potentially decisive first strike, thereby risking its survival, would completely alter customary law as it existed at the birth of the UN and "protect the aggressor's right to the first stroke," ${ }^{461}$ a logically and morally bankrupt conclusion. ${ }^{462}$ ASD is

\footnotetext{
${ }^{457}$ In the strict sense, the doctrine of ASD is inapplicable to ongoing conflicts, under which circumstances the formal state of belligerence has been created, military operations are not designed to anticipate enemy attacks, and the rights of belligerents to self-defense cannot be said to depend upon whether it is possible to demonstrate an imminent threat, as the threat exists from the moment of the first strike. See Schmitt, supra note 454, at 535 ("Once the first attack in an ongoing campaign has been launched, the issue of [ASD] becomes moot.").

${ }^{458}$ Some commentators add the requirement that the threat be of sufficient magnitude as to justify resort to ASD on the theory that lesser threats can be managed without resort to force. Addicott, supra note 444, at 778.

${ }^{459}$ A number of commentators hew to the restrictivist position and reject the post-Charter viability of the customary international law doctrine of ASD as incompatible with the regime regulating the resort to armed conflict established by the Charter. See, e.g., DINSTEIN, supra note 433, at 159-85; LOUIS HENKIN, INTERNATIONAL LAW: POLITICS AND VALUES 8-10, 121-22 (1995); ANTHONY D'AMATO, INTERNATIONAL LAW: PROCESS AND PROSPECT 32 (1987); BROWNLIE, supra note 449, at 257-61, 273-79, 366 67 Jules Lobel, The Use of Force to Prevent Terrorist Attacks, 24 YALE J. INT'L L. 537, 541 (1999). At least one restrictivist approves ASD on policy grounds but rejects the doctrine as incompatible with the Charter. See Michael J. Glennon, The Fog of Law: Self-Defense, Inherence, and Incoherence in Article 51 of the United Nations Charter, 25 Harv J L \& Pub Poly 539, 539 (2002) (suggesting that although ASD can be a sound policy argument "it would plainly violate Article 51 of the United Nations Charter").

${ }^{460}$ See Derek Bowett, Reprisals Involving Recourse to Armed Force, in International Law: A Contemporary Perspective 394-410 (Richard A. Falk eds. 1985) (developing arguments in support of this concern).

${ }^{461}$ Waldock, supra note_, at 498; see also id. "[I]t would be a travesty of the purposes of the Charter to compel a defending State to allow its assailant to deliver the first, and perhaps fatal, blow[.]"); Christopher Clarke Posteraro, Intervention in Iraq: Towards a Doctrine of Anticipatory Counter-Terrorism, FLA. J. INT'L L. 151, 184-85 (2002) (extrapolating the logic of a prohibition on ASD into a blanket of territorial inviolability for states that harbor the "most blatant preparation for an assault upon another state's independence[.]").

${ }^{462}$ "Suppose military intelligence at the Pentagon received indisputable evidence that a hostile State was poised to launch intercontinental ballistic missiles, at a fixed zero hour only 24 hours ahead, against New York, Boston and Washington, would it be an aggressor under the Charter if it refused to wait until those cities had received the missiles before it reacted by the use of force? .. . [I]s it bound by law to wait for its own destruction?" STONE, supra note 449, at 99. Some restrictivists concede that a coherent theory of legal regulation of force in international relations must make room for ASD in some very limited circumstances. See, e.g., DINSTEIN, supra note 433, at 172-75 (arguing that the U.S. could legally have attacked the Japanese fleet en route to Pearl Harbor on the ground the U.S. had "clear and convincing" intelligence that the Japanese were committed to attack); WALZER, supra note 36, at 81 (allowing the permissibility of ASD where the enemy demonstrates "a manifest intent to injure, a degree of active preparation that makes that intent a positive danger, and a general situation in which waiting, or doing anything other than fighting, greatly magnifies the risk."); WOLFGANG FRIEDMANN, THE THREAT OF TOTAL
}

DESTRUCTION AND SELF-DEFENSE 259-60 (1964) ("[I]n the absence of effective international machinery the right of selfdefence must . . . be extended to the defence against a clearly imminent aggression, despite the apparently contrary language of Article 51[.]"). However, not all restrictivists are as tolerant of even a slight exception, and thus representatives to the San Francisco Conference questioned whether the argument that the Charter could be construed to abolish customary rights of selfdefense was politically and legally defensible. See, e.g., U.N. Doc.A/2211, paras. 392-93 (indicating questioning of the delegates by Representative Maktos (U.S.) and van Glabbeke (Belgium) as to whether the U.S., if it had received prior notice of an impending Japanese attack on Pearl Harbor, would have been branded an aggressor had it engaged in ASD to destroy the Japanese forces detailed to bomb Pearl Harbor). A former jurist of the ICJ demonstrates the continued incongruity of the restrictivist position nearly sixty years later:

[C]ommon sense cannot require one to interpret an ambiguous provision in a text in a way that requires a state passively to accept its fate before it can defend itself. And, even in the face of conventional warfare, this would also seem the only realistic interpretation of the contemporary right to self-defence ... [T] his view accords better with State practice and with the realities of modern military conditions than with the more restrictive interpretation of Article 51[.] ROSALYN HIGGINS, PROBLEMS AND PROCESS: INTERNATIONAL LAW AND HOW WE USE IT 242 (1994). 
thus, for pragmatists, consistent with the entitlement of states to defend against brewing threats even before they are attacked. ${ }^{463}$

\section{B. Operationalization}

A sharp theoretical bifurcation on the question of the lawfulness of ASD in the abstract dictates the result that ASD is almost invariably appraised in light of, and following, specific applications in practice. Moreover, although a specific exercise of ASD is immediately opened to contestation, its legal legitimacy is often not ripe for review until long afterwards, when the defending state finally declassifies and submits the sensitive intelligence that established the factual predicate upon which its decision to act rested to public review. ${ }^{464}$ Accordingly, it is difficult to assess a particular act of ASD as "legal" or "illegal" ipso facto. However, it is possible to establish causal linkages between personality profiles and decisions to resort to, or refrain from, the exercise of ASD under circumstances where the question as to whether or not to act in anticipation of a potential attack arises or might reasonably have arisen, and, secondarily, to link personality profiles to third party decisions as to whether instances of resort to ASD are lawful or otherwise justified.

Accordingly each DV will be dichotomized and scored as a either "yes" for the presence of the outcome or "no" for its absence. Operationalization of DVs 1-3 are self-explanatory; DV 4 requires simply an assessment of whether the defending state offers any justification whatsoever for its actions;

\footnotetext{
${ }^{463}$ For a discussion of ASD as the natural legal duty of states, see William Bradford, The Duty to Defend Them: A Natural Legal Justification for the Bush Doctrine of Preventive War, 79 NOTRE DAME L. REV. 101 (2004, forthcoming).

${ }^{464}$ Some commentators insist that states engaging in ASD submit to an international "jurying" process whereby the evidence adduced by the state seeking a variance is "tried" aforehand with the onus on the requesting state to prove its purity of motives, the proportionality of the proposed use of force, and the severity of the threat. See Thomas M. Franck, The Use of Force in International Law, 11 TUL. J. INT'L \& COMP. L. 7, at 15-17 (2003); Thomas Graham, National Self-Defense, International Law, and Weapons of Mass Destruction, 1 CHI. J. INT'L L. 1, 14 (2003) insisting that if international relations is to become lawgoverned, "states must openly justify their actions[,]" to include decisions to engage in ASD, to the review of states and international organizations). However, considerations of bureaucratic inefficiency, opposing political interests, and the absence of effective transnational procedures for protecting shared intelligence sources and methods militate against submission to an international jury. To wit, the establishment of the factual predicate of an imminent threat is a time-consuming process made all the more so by the machinery of the UN system. See Post-Cold War International Security Threats: Terrorism, Drugs, and Organized Crime Symposium, MICH. J. INT'L L. 655, 716 (discussing bureaucratic inefficiencies and glacial pace of the UN system); Michael A. Lysobey, How Iraq Maintained its Weapons of Mass Destruction Programs: An Analysis of the Disarmament of Iraq and the Legal Enforcement Options of the United Nations Security Council in 1997-19985 U.C.L.A. J. INT'L L. \& FOR. AFF. 135, 152-53 (2000) (describing Security Council as "plodding" and subject to the "whim of whatever political and economic factors are motivating the Council."). Moreover, proof requires the sharing of intelligence, something states are loathe to do with all but their closest allies for fear that revelation of the evidence will permit deductions as to how the evidence was acquired (methods) and by whom (sources), as well as the possibility that reviewers sympathetic to the target might share the intelligence with the target. Sara N. Scheideman, Standards of Proof in Forcible Responses to Terrorism, 50 Syracuse L. Rev. 249 (2000); see also Linkie, supra note_, at 573 (explaining that the U.S. cannot reveal all its evidence without compromising the human intelligence sources, who may be placed within terrorist organizations or supply networks, or disclosing its methods of interception and decryption of enemy communications); Ruth Wedgwood, Responding to Terrorism: The Strikes Again bin Laden, 24 YALE J. INT'L L. 559, 567 (1999) (“[I]n the midst of a . . war, a country defending its territory and its nationals will rarely be able to disclose intelligence sources in a public forum."); Graham, supra this note, at 7 (conceding that it is very unrealistic to suggest that states be forced to disgorge the intelligence upon which they rely in taking measures to preempt attack). Moreover, even after reviewing the evidence, states unwilling on other grounds to approve a proposed exercise of ASD are far less likely to concede that the proffered evidence is probative of the existence of an imminent threat. Id. Worse yet, the inaccessibility of the target state to the state engaging in ASD, coupled with the interest of target states in concealing relevant evidence of WMDs or terrorist training centers that would otherwise supply the "smoking gun" creates difficulties in acquiring and assembling all the evidence necessary to establish the factual predicate beyond a reasonable doubt that would be required in a domestic criminal case, yet the most strident critics of a particular exercise of ASD are likely to demand that the acting state clear this evidentiary hurdle. John-Alex Romano, Combating Terrorism and Weapons of Mass Destruction: Reviving the Doctrine of a State of Necessity, GEORGETOWN L.J. 1023, 1039-40 (1999). Even if the burden of proof were to be reduced to merely require a state to prove the facts justifying an exception to the general prohibition against selfhelp by "sophisticated pleading backed by relevant and highly probative evidence," as some suggest should suffice, states will be hard-pressed to satisfy this lesser standard. Franck, supra note 465, at 16.
} 
DV 5 directs an inquiry into whether and how other states and the UN judge the lawfulness of the exercise of ASD, whereas DV 6 examines whether, although other states regard the act of ASD to have been formally unlawful they nonetheless recognize the legitimacy of its exercise in the specific circumstances by refraining from statements of condemnation; DV 7 is an assessment of whether formal legal sanctions are imposed upon the defending state; DV 8 is an assessment of whether, after the passage of time and the revelation of additional facts bearing upon the imminence of the threat, the act of ASD is now regarded as lawful and/or legitimate by other states; DV 9 is self-explanatory; and DV 10 requires a subjective assessment of whether, in light of all the available evidence and without any regard to the legality of the act of ASD in question, the actions of the defending state can objectively be said to have been preservative of peace, stability, justice, the rule of law, and/or other superordinate values held in common by the international community.

\section{Causal Linkages and Preliminary Hypotheses}

The following linkages between independent and dependent variables are proposed at this juncture as preliminary hypotheses [“PHs"]:

1. The more militaristic the decisionmaker the more likely s/he will be to consider ASD as an option;

2. The more militaristic the decisionmaker the more likely s/he will be to engage in ASD;

3. The more militaristic the decisionmaker the less likely s/he will be to defend the use of ASD;

4. The more militaristic the less likely s/he will be to defend the use of ASD on legal, as opposed to strategic, grounds;

5. The more militaristic the decisionmaker the less likely most other actors will be to judge the use of ASD to be lawful;

6. The more militaristic the decisionmaker the less likely most other actors will be to regard an exercise of ASD as legitimate;

7. The more militaristic the decisionmaker the less likely other actors will be to impose legal sanctions;

8. The more militaristic the decisionmaker the more likely other actors will be to regard an exercise of ASD as lawful and/or legitimate in retrospect;

9. The more militaristic the decisionmaker the more likely s/he will be, in hindsight, to make the same decision again with regard to ASD;

10. The more militaristic the decisionmaker the less likely his/her decision with regard to ASD can fairly be said to have supported world order;

11. The more anomistic the decisionmaker the more likely s/he will be to consider ASD as an option;

12. The more anomistic the decisionmaker the more likely s/he will be to engage in ASD;

13. The more anomistic the decisionmaker the less likely s/he will be to defend the use of ASD;

14. The more anomistic the decisionmaker the less likely s/he will be to defend the use of ASD on legal, as opposed to strategic, grounds;

15. The more anomistic the decisionmaker the less likely most other decisionmakers will be to judge the use of ASD as lawful;

16. The more anomistic the decisionmaker the less likely most other actors will be to regard an exercise of ASD as legitimate;

17. The more anomistic the decisionmaker the less likely other actors will be to impose legal sanctions;

18. The more anomistic a decisionmaker the less likely other actors will be to regard an exercise of ASD as lawful and/or legitimate in retrospect;

19. The more anomistic a decisionmaker the more likely s/he will be, in hindsight, to make the same decision again with regard to ASD;

20. The more anomistic the decisionmaker the less likely his/her decision with regard to ASD can fairly be said to have supported world order;

21. The more hostile the decisionmaker the more likely s/he will be to consider ASD as an option;

22. The more hostile the decisionmaker the more likely s/he will be to engage in ASD;

23. The more hostile the decisionmaker the less likely s/he will be to defend the use of ASD;

24. The more hostile the decisionmaker the less likely s/he will be to defend the use of ASD on legal, as opposed to strategic, grounds;

25. The more hostile the decisionmaker the less likely most other decisionmakers will be to judge the use of ASD to be lawful; 
26. The more hostile the decisionmaker the less likely most other actors will be to regard an exercise of ASD as legitimate;

27. The more hostile the decisionmaker the less likely other actors will be to impose legal sanctions;

28. The more hostile a decisionmaker the more likely other actors will be to regard an exercise of ASD as lawful and/or legitimate in retrospect;

29. The more hostile a decisionmaker the more likely s/he will be, in hindsight, to make the same decision again with regard to ASD;

30. The more hostile the decisionmaker the less likely his/her decision with regard to ASD can fairly be said to have supported world order;

31. The more adventurist the decisionmaker the more likely s/he will be to consider ASD as an option;

32. The more adventurist the decisionmaker the more likely s/he will be to engage in ASD;

33. The more adventurist the decisionmaker the more likely s/he will be to defend the use of ASD;

34. The more adventurist the decisionmaker the more likely s/he will be to defend the use of ASD on legal as well as strategic grounds;

35. The more adventurist the decisionmaker the more likely most other decisionmakers will be to judge the use of ASD to be lawful.

36. The more adventuristic the decisionmaker the more likely most other actors will be to regard an exercise of ASD as legitimate;

37. The more adventuristic the decisionmaker the less likely other actors will be to impose legal sanctions;

38. The more adventuristic a decisionmaker the more likely other actors will be to regard an exercise of ASD as lawful and/or legitimate in retrospect;

39. The more adventuristic a decisionmaker the less likely s/he will be, in hindsight, to make the same decision again with regard to ASD;

40. The more adventuristic the decisionmaker the more likely his/her decision with regard to ASD can fairly be said to have supported world order.

\section{Personality and IHL Compliance: Testing the Theory}

\section{A. Data}

Testing the theory requires analysis of available psychobiographical data concerning those HDs who made verifiable decisions with respect to whether to engage in ASD during historical armed conflicts in circumstances where a claim of right to engage in ASD, however contestable, either was made or could arguably have been made on the basis of available facts. ${ }^{465}$ Because the legal subregime regarding ASD did not arise until, arguably, 1929, data is necessarily unavailable before that year. ${ }^{466}$ However, available data, drawn from a series of 11 military crises, including World War II (1939-1945) the Cuban Missile Crisis (1962), the Six Day War (1967), the October War (1973), the Strike on Osiraq (1981), Libya (1986), Panama (1989), Iraq (1993), North Korea (1996), Afghanistan and Sudan (1998), and Iraq (2003), as well as from psychobiographical sources, ${ }^{467}$ permits dichotomous measurement and scoring of each relevant HD on each personality construct. The universe of HDs encompasses 6 U.S. Presidents (Franklin D. Roosevelt, John F. Kennedy, Ronald W. Reagan, George H.W. Bush, William J. Clinton, and George W. Bush) and 4 HDs of other nationalities (Josef Stalin, Levi Eshkol, Golda Meir, and Menahem Begin).

1. World War II (1939-1945)
a. Josef Stalin, Soviet Union: OPERATION BARBAROSSA (1941)
i. IVs: scores on personality constructs
a. militarism

\footnotetext{
${ }^{465}$ The selection of cases in the present study may be faulted for over- or under-inclusiveness; however, it is intended not to authoritatively resolve the question of which exercises or force, or failures to exercise force, can be considered as instances of ASD but rather as a means to test a theory, prompt discussion, and generate future research directions.

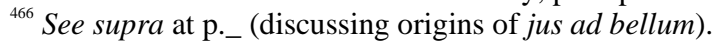


Soviet premier Josef Stalin ["JS"] was a Georgian ideologue who reposited his loyalty not in the Georgian nation or even the Soviet state but rather in international communism. Nevertheless, a communism triumph was an objective for which JS violently and diligently labored his entire life, first as a professional revolutionary and bank robber, then as a brutal organizational man in the Bolshevik structure, and finally as the Soviet premier, ${ }^{468}$ and because "nationalism" includes a belief in the superiority of a "philosophy of government" ${ }^{\text {"469 }} \mathrm{JS}$ is scored as a nationalist. JS was a brutal dictator and a pure authoritarian who ruled by mass purges, engineered starvation, show trials, and fear, and he ordered over 30 million Soviets to their deaths over a twenty-year period. ${ }^{470}$

Although JS lacked military experience or knowledge and in fact held a low opinion of the military, ${ }^{471}$ he was a hyper-competitive and -ambitious personality with a "single-minded sense of purpose" who believed a great struggle—economic, political, and military—was necessary to defeat capitalism and fascism. ${ }^{472} \mathrm{He}$ was a consummate dogmatist who despised intellectuals and was "totally convinced that he was always right and the only person farsighted enough to lead his country." ${ }^{473}$ JS was a socially withdrawn introvert with no interests save statecraft and no personal friends, and in fact others avoided him out of fear. ${ }^{474}$ Still, JS was a "man of enormous self-confidence" and self-esteem who scores high on all subconstructs of militarism save for military experience, and thus is scored as a militarist.

\section{b. anomism}

JS possessed a "strong streak of criminality and madness" the seminary and induced him into an early career as a revolutionary, terrorist gunman, and bank robber. ${ }^{476}$ He was corrupt to the core, ${ }^{477}$ "devoid of any scruples" and a "master of sanctimoniousness, hypocrisy, and mendacity" ${ }^{478}$ who never experienced guilt or remorse for his mass murder of millions. ${ }^{479}$ JS, who had no legal training, scores high on every subconstruct of anomism and is scored an anomist.

\section{c. hostility}

Psychobiographers have reached a near-consensus that JS was a megalomaniac, a narcissist, ${ }^{480}$ and a clinical paranoid ${ }^{481}$ whose deep-seated antipathy toward the West was the animating force of his life. ${ }^{482}$ JS was a "first-rate tactician, intriguer, and plotter, playing enemies and potential enemies against

\footnotetext{
${ }^{467}$ See POST, supra note 232 (describing sources of psychobiographical data, including biographies, content analyses of speeches, press conferences, addresses, informal remarks, Weekly Compilation of Presidential Documents, etc.).

${ }^{468}$ WALTER LAQUEUR, STALIN 7-9 (1999) (chronicling JS's violent rise through the Communist system); Michael G. Smith, Stalin's Martyrs: The Tragic Romance of the Russian Revolution, in Redefining Stalinism (Harold Shukman ed. 2003), at 100-02 (same).

${ }^{469}$ See supra at p._.

${ }^{470}$ LAQUEUR, supra note 469, at 10, 33-34, 134.

${ }^{471} I d$. at 91, 219, 224 (noting JS's disregard for and tactical and strategic ignorance of military matters).

${ }^{472}$ Id. at 14,149 .

${ }^{473}$ Id. at 160 .

${ }^{474}$ See id. at 8, 147, 160 (describing JS as an introvert feared by others).

${ }^{475} I d$. at 12 .

${ }^{476} \mathrm{Id}$. at 7-8.

${ }^{477}$ See Jefffrey Brooks, Stalin's Politics of Obligation, in Redefining Stalinism, supra note 469, at 50 (describing the "gift-giving, bribery, [an] official favours" JS used to cement political relationships among cronies).

${ }^{478}$ LAQUEUR, supra note 469 , at 14.

${ }^{479} I d$. at 132.

${ }^{480}$ See id. at 15 (noting that JS demanded extravagant praise in official biographies, poems, plays, songs, and other media and thrived on a cult of personality).

${ }^{481}$ See id. at 134 (discussing expert opinions as to clinical diagnosis of JS).

${ }^{482}$ LAQUEUR, supra note 469, at 204.
} 
the other[,]"and as his deeds and his utter amoralism together attest, if only one pure cynic, misanthrope, and Machiavellian has ever walked the earth, his name was Joseph Stalin. ${ }^{483}$ Although JS's fixation was ideological rather than ethnocentric, he hated his son in large measure for his marriage to a Jew. ${ }^{484}$ JS was a hostile, brutal man devoid of empathy and ruthlessly selfish, and under JS the Soviet Union had no allies, only temporary non-enemies. ${ }^{485}$ In short, JS scores high on every subconstruct of hostility and thus is scored as hostile.

d. aventurism

JS's entire political program—communism—was predicated upon the assumption that mankind had the power to bring about the end of history, and although JS lived during a period of extreme trial and tribulation he remained remarkably optimistic that communism would succeed and that the Soviet Union would triumph over Nazi Germany. ${ }^{486}$ His early criminality and his failure to consider the consequences of the 1930s show trials, which destroyed the nucleus of the Red Army and many of the scientists that would prove necessary to the defeat of Nazism, suggests that JS was a risk-tolerant and impulsive personality. ${ }^{487} \mathrm{JS}$ thus scores high on all subconstructs of adventurism and is scored an adventurist.

e. summary of independent variables: JS

JS is scored as militaristic, anomistic, hostile, and adventuristic.

\section{ii. DVs: ASD and OPERATION BARBAROSSA}

Despite ample evidence that Germany intended to launch OPERATION BARBAROSSA—-the invasion of the Soviet Union—in spring $1941,{ }^{488} \mathrm{JS}$, whether convinced that reports were the product of a vast Allied conspiracy, ${ }^{489}$ that Hitler would not attack until defeating the UK, that a rapprochement with Hitler was possible, ${ }^{490}$ or that Soviet forces were unprepared for war until 1942 at the very least, did not seriously consider or engage in ASD. ${ }^{491}$ It is unlikely JS would have made a different decision if given the opportunity, as it is unclear whether a military advantage would have accrued to the Soviet Union while the political costs of attacking Germany would likely have outweighed any minor gains.

b. Franklin D. Roosevelt, U.S.: Pearl Harbor (1941)

i. IVs: scores on personality constructs

1. militarism

\footnotetext{
${ }^{483}$ See Robert Service, Stalinism and the Soviet State Order, 7, 8, in Redefining Stalinism, supra note_ (describing JS's view that humanity was a "mass to be indoctrinated, mobilised and . . sacrificed for the good of the cause.").

${ }^{484}$ LAQUEUR, supra note 469, at 153.

${ }^{485}$ See generally id. (describing tempestuous and uncertain relationships of JS's Soviet Union with supposed "allies").

${ }^{486}$ See id. (describing JS as a calm and optimistic person even during moments of seeming despair).

${ }^{487}$ See supra note 471 (discussing the deaths of millions during the show trials).

${ }^{488}$ See LAQUEUR, supra note 469, at 89, 220 (stating that JS had documentary evidence of the impending OPERATION BARBAROSSA but deliberately ignored it); Christopher Andrew \& Julie Elkner, Stalin and Foreign Intelligence, in Redefining Stalinism, supra note 469, at 78 (noting that a great many Soviet intelligence agents and military intelligence officers reported Nazi preparations to attack Russia throughout June 1941).

${ }^{489}$ Id. at 78 (describing JS's "pathologically suspicious" approach to intelligence analysis and his denunciations of those who warned him, accurately, of the impending German attack as "disinformer[s]").

${ }^{490}$ LAQUEUR, supra note 469, at 131 . JS may have believed it possible to stave off conflict with Germany by exploiting the war between the Allies and the Nazis and creating a territorial buffer of Eastern Europe. See, e.g., SILVIO PONS, STALIN AND THE INEVITABLE WAR 1936-1941 xiii, 216-19 (2002) (offering this explanation for Soviet inaction in 1941).

${ }^{491}$ Uri-Bar Joseph \& Arie W. Kruglanski, Intelligence Failure and Need for Cognitive Closure: On the Psychology of the Yom Kippur Surprise, 24 POL. PSYCH. 75, 75-76, 94. Although the Soviet High Command presented JS with a plan for ASD against Germany, JS did not give it serious consideration. PONS, supra note 491, at 220. 
Although he did not harbor notions of the racial or ethnic superiority of the people of the U.S., President Franklin D. Roosevelt ["FDR"] was a patriotic nationalist who believed that the U.S. was a unique nation, by virtue of its democratic traditions and devotion to liberty, ${ }^{492}$ with a special historical mandate that charged him with a duty to lead its people through their struggle to overcome the Great Depression and the menace of fascism to a "rendezvous with destiny." ${ }^{\text {"493 }}$ Recognizing and deeply valuing power as an instrument of policy, FDR led the U.S. in amassing and deploying tremendous military might to the defeat of the Axis powers. ${ }^{494}$ Although he had a tendency to be domineering and assertive, FDR was not an aggressive personality. ${ }^{495}$ Nevertheless, he had a strong authoritarian streak that manifested in his hierarchical management style, his unwillingness to consult with advisors, and his insensitivity to subordinates, ${ }^{496}$ and although FDR cannot be fairly described as a militarist, ${ }^{497}$ and despite his lack of military experience, ${ }^{498}$ he did not shy from the use of force to defend his core values. Curiously, despite his lofty accomplishments and great ambition, ${ }^{499}$ FDR was not a particularly competitive person, ${ }^{500}$ and his choice of the Democratic Party as his political home was to a large extent predicated upon his desire to avoid the unpleasantry of competing for office-holding with his nephews, the sons of former President Teddy Roosevelt and members of the GOP. ${ }^{501}$

Although FDR was of above-average intelligence with a powerful memory and great personal energy, ${ }^{502}$ he is described as a "second-rate intellect" of fairly limited cognitive complexity. ${ }^{503}$ At the same time, although FDR was superlative at and very interested in maintaining interpersonal relationships, his interest in affiliation may have been primarily instrumental: he has been characterized as "difficult to know," "aloof," and disinterested in personal friendships. This characterization may be a function of perceptions of the low self-esteem that plagued FDR following his debilitating battle with polio and his confinement to a wheelchair.

FDR scores high on nine of thirteen subconstructs of militarism - nationalism, FAP, patriotism, authoritarianism, dogmatism, ambitiousness, introversion, isolationism, and low self-esteem —and thus is scored as a militarist.

2. anomism

\footnotetext{
${ }^{492}$ GREENSTEIN, supra note 227, at 24 (emphasizing FDR's strong valuation of democracy and of an American role in world democratic leadership).

${ }^{493} I d$. at 16 . FDR came to believe in his teens or early twenties that "he would become God's chosen, and the American people's constitutionally elected, instrument for the stewardship of his country." CONRAD BLACK, FRANKLIN DELANO ROOSEVELT 39 (2003).

${ }^{494} I d$. at 24.

${ }^{495}$ See Steven J. Rubenzer \& T.R. Fashingbauer, Testing the Presidents: Personality and Character(s) Among America's Leaders (unpublished manuscript, 2002) (on file with author).

${ }^{496}$ LEWIS L. GOULD, THE MODERN AMERICAN PRESIDENCY 90 (2003); see also GREENSTEIN, supra note 227 , at 22 (noting that FDR purposefully fostered rivalries between his aides to buttress his authority).

${ }^{497}$ See ROBERT S. THOMPSON, A TIME FOR WAR 43 (1991) (quoting FDR as describing war as a "contagion"). Still, it is impossible to label FDR, a major agitator for U.S. entry into World War I, a pacifist. BLACK, supra note 494, at 72-73.

${ }^{498} I d$. at 83 (reporting that FDR offered to resign as Secretary of the Navy to serve in the armed forces but was requested to withdraw his resignation by President Wilson).

${ }^{499}$ See id. at 25 (describing FDR as ambitious to the point of being "nasty" and of attributing setbacks to "malice or unfairness" rather than to his own failings); Rubenzer, supra note 496.

${ }^{500}$ See BLACK, supra note 494, at 53 (describing FDR as a person committed to "dilettantism" who "[went] through the motions to get along" at Groton, Harvard, Columbia Law School, and on Wall Street)/

${ }^{501}$ GREENSTEIN, supra note 227, at 14.

${ }^{502}$ GOULD, supra note 497 , at 89.
} 
Although FDR publicly hailed the rule of law as one of the virtues of liberal democracy, and its absence as one of the vices of totalitarianism, in his private persona FDR regarded law as primarily a constraint susceptible to manipulation. As Assistant Secretary of the Navy, he was censured by the Senate for using illegal investigative means to identify and entrap homosexual sailors. ${ }^{504}$ When faced with a hostile Supreme Court, he attempted to change its composition by legislative fiat, ${ }^{505}$ and, as evidenced by his order interning Japanese Americans during World War $\mathrm{II}^{506}$ and his approval of illegal wiretaps and postal interceptions, ${ }^{507}$ constitutional rights were, for FDR, subordinate to his role as commander in chief during wartime, which role he exercised largely independent of democratic political constraints prior to late $1941 .^{508}$ His attempts to transform legal institutions and rules or, alternatively, to interpret law to serve his objectives, suggests that FDR regarded legal authority, just as law, as external constraints that could be overcome by contrary power. ${ }^{509}$ Similarly, although FDR described the Axis powers as an "unholy alliance," ${ }^{510}$ he did not always demonstrate a commitment to strong moral precepts in his personal life, having succumbed to a decades-long affair with his secretary beginning in 1918 that irreparably damaged his marriage. ${ }^{511}$ Available evidence strongly suggests that, although he attended Columbia Law School until 1906 (it is unlikely he had any training in IHL), ${ }^{512}$ for FDR moral considerations did not generate any duty to adhere to legal commands. Accordingly, FDR scores high on four subconstructs of anomism—disrespect for law, disrespect for legal authority, amoralism, and ignorance of IHL—and thus is scored an anomist.

\section{3. hostility}

FDR, although neither a paranoid nor a misanthrope, was a cynical, suspicious $\operatorname{man}^{513}$ who anticipated the worst in others and did not abstain from manipulation to accomplish his objectives. ${ }^{514}$ Similarly, FDR has not been described as either particularly empathetic or altruistic: he was a realist who

\footnotetext{
${ }^{503}$ GREENSTEIN, supra note 227, at 24-25 (highlighting an insensitivity to abstraction and a "striking capacity to ignore disagreeable realities"). 
understood and appreciated the relevance of power and self-interest in international relations. Still, his alliance preferences were motivated by instrumental concerns and not by a common ethnicity or culture, and as such he was not clinically ethnocentric. ${ }^{515}$ Moreover, FDR did not detach from reality, nor did he demonstrate the recklessness associated with narcissists.

Furthermore, FDR was, even if by necessity rather than by design, a committed internationalist who recognized and capitalized upon the need for cooperative relationships with allies in order to defeat the Axis. ${ }^{516}$ Although FDR exhibited some of the values associated with Machiavellianism, ${ }^{517}$ particularly during the two years before U.S. entry into World War II ${ }^{518}$ he cannot be characterized as entirely ruthless or utterly amoral, ${ }^{519}$ and the better description might be that he was a calculating, self-interested realist. Accordingly, because he scores high on five of ten subconstructs of hostility—distrust, cynicism, hostility, lack of empathy, and selfishness-FDR can be scored as either hostile or non-hostile; artful intuition directs the scoring of FDR as hostile.

4. adventurism

Although he strongly believed in his ability to transform the domestic and international order, and although he was an optimist who assured the American people that "they only thing [they] ha[d] to fear was fear itself, ${ }^{, 520}$ FDR was a cautious, risk-avoiding person who, during the most stressful decade of history, waited for situations to develop before committing himself. ${ }^{521}$ FDR recognized the limitations of will and the vagaries of fate and waited for the proper correlation of both, so much so that many scholars suggest that his over-caution resulted in failures to "exploit the leadership possibilities of the modern presidency." ${ }^{522}$ However, FDR was calm, even serene, during stressful times, ${ }^{523}$ and because the best available evidence suggests that FDR scores high on only three subconstructs of adventurism—optimism, stress, and male sex-he is scored as a non-adventurist.

5. summary of independent variables: FDR

FDR is scored a militarist who is anomistic and hostile and yet not adventuristic.

ii. DVs: ASD and Pearl Harbor

\footnotetext{
${ }^{515}$ See JENKINS, supra note 505, at 140 (suggesting that although he refused to desegregate the armed forces, FDR was not racist or ethnocentric but simply pragmatic and unwilling to be "too much in advance of public opinion"); BLACK, supra note 494, at 49 (noting that FDR was tolerant of Jews and other ethnic groups even in the face of others' social prejudice).

${ }^{516}$ Additionally, FDR proposed several pre-war plans for Europe-wide collective security and trade liberalization that would have relied upon substantial U.S. participation had the Axis powers accepted them. Id. at 515-16.

${ }^{517}$ See, e, g, JENKINS, supra note 505, at 108 (describing FDR as Machiavellian for pretending to search for a successor after his second term while in reality only offering up unacceptable alternatives to create the impression that he was indispensable and thus deserving of a third term); see also BLACK, supra note 494, at 25 (describing "notorious" traits and "devious tendencies" of FDR, including the exaggeration of personal achievements and the denial of personal responsibility for shortcomings); id. at 540 (describing FDR as "ruthless" in matters of foreign policy).

${ }^{518}$ See, e.g., THOMPSON, supra note 498, at 274-77describing FDR's secret diplomacy and his 1940 campaign promises to keep the U.S. out of World War II, a promise he had been intending to breach for at least two years); id. at 279-80 (describing how FDR offered Hollywood producers convicted of income tax evasion sentence deals in exchange for their release of overtly patriotic films to generate public support for his pro-war policy); id. at 354 (recounting FDR's fabrication of a German attack upon a U.S. vessel).

${ }^{519}$ See BLACK, supra note 494, at 829 (describing FDR as "just as Machiavellian as Hitler or Stalin at times, though, unlike them, he had a proper humanitarian concern for the consequences of his actions[.]").

${ }^{520}$ Franklin D. Roosevelt, Inaugural Address, Washington, D.C., Mar. 4, 1933.

${ }^{521}$ GOULD, supra note 497 , at 81.

${ }^{522} \mathrm{Id}$. at 91.

${ }^{523}$ See BLACK, supra note 494, at 39 (indicating that the source of FDR's lack of anxiety was his "sense of oneness with the ongoing processes of the universe an dhis feeling of being ... in tune with the infinite.") (citation omitted).
} 
Prior to the Japanese attack on Pearl Harbor on December 7, 1941, the U.S. undertook no estimate of the likelihood of such an attack, no determination of the probability of the damage that might be incurred, and no measures of preemption. ${ }^{524}$ Quite simply, the U.S., despite a series of warnings that an attack was part of a Japanese plan to dominate the Pacific, did nothing. ${ }^{525}$ Despite the impetus for FDR to at least contemplate ASD against Japan, he did not. ${ }^{526}$ Overconfidence, a widespread belief that the Japanese would not launch a surprise attack, ${ }^{527}$ and an overwhelming preoccupation with the German threat to the detriment of planning for a Pacific war have been offered as explanations, ${ }^{528}$ others suggest that FDR was committed to entering the war but simply refused to do so save for in circumstances that could not be characterized as other than self-defense. ${ }^{529}$ Still, given the opportunity to revisit the decisional moment and preempt the Imperial Fleet at sea, where U.S. naval power was more than a match, it is hardo imagine FDR, a man who knew war was inevitable and could have used his vast rhetorical power to explain to the American people that the Japanese attack had already been underway, would have refrained from doing so.

2. President John F. Kennedy and the Cuban Missile Crisis (1962)

a. IVs: personality constructs

i. militarism

John F. Kennedy ["JFK"] was an ardent nationalist who challenged Americans to rise to the burden of national service and dedicated his presidency to the fulfillment of a historic duty to "pay any price, bear any burden, meet any hardship, support any friend, oppose any foe to assure the survival and success of liberty[.]" ${ }^{, 530}$ During World War II he served valorously in the South Pacific, setting the stage for his political career, and throughout his life he retained the belief that power was indispensable to the defense of freedom. ${ }^{531}$ However, JFK's highly collegial and respectful management style disqualified him as an authoritarian, ${ }^{532}$ and although a spirit of intense competitiveness and an "overpowering need for achievement" were legacies of his domineering father, he did not adopt an aggressive approach to

\footnotetext{
${ }^{524}$ For a comprehensive examination of the failure of the U.S. to anticipate and prevent the attack on Pearl Harbor, see generally WOHLSTETTER, supra note 424.

${ }^{525}$ See THOMPSON, supra note 498, at 369-88, 399400 (chronicling U.S. advance warning of the Japanese attack);

${ }^{526}$ See BLACK, supra note 494, at 669 (indicating FDR knew that under U.S. economic embargo Japan, starved of material resources, would be obligated either to abandon its territorial ambitions in Southeast Asia or, more likely, attack the U.S.).

${ }^{527}$ In his address to Congress on 8 December 1941, FDR expressed moral outrage that Japan would have "suddenly and deliberately" attacked., that Japan "deliberately planned [the attack on Pearl Harbor] many days or weeks ago" and that Japan would have "deliberately sought to deceive the United States by false statements and expressions of hope for a continued peace." Franklin D. Roosevelt, Address to Joint Session of Congress Requesting a Declaration of War with Japan, Dec. 8, 1941. The choice of language suggests that FDR considered it highly improbable at best that a state would engage in such "treachery" as to undertake war with another state without first declaring war. Id.

${ }^{528}$ See generally WOHLSTETTER, supra note 424 (detailing in depth the origins of U.S. failure to anticipate Pearl Harbor).

${ }^{529}$ See JENKINS, supra note 505, at 131 (reporting that during the summer of 1941 FDR commented to aides that he "was not willing to fire the first shot" and that he was "waiting to be pushed into [war].”) (quoting FDR); BLACK, supra note 494, at 676 (stating that FDR "acquiesced knowingly in a policy that would result in a Japanese attack"); id. at 679 (describing FDR as "insistent on allowing [Japan] the first blow" in order to mobilize domestic opinion in favor of war).

${ }^{530}$ John F. Kennedy, Inaugural Address, Washington, D.C., Jan. 20, 1961.

${ }^{531}$ See J.F. Kennedy, The Cuban Missile Crisis, in T. Windt, ed.,, Presidential Rhetoric: 1961 to the Present, 3 rd ed., at 9-11 ("[I]t is clear that the forces of communism are not be underestimated. . If the self-discipline of the free cannot match the iron discipline of the nailed [sic] fist-in economic, political, scientific and all the other kinds of struggles as well as the militarythen the peril to freedom will continue to rise.").

${ }^{532}$ VALENTY \& FELDMAN, supra note 226, at 163-65.
} 
interpersonal relationships and in fact expressed a strong antipathy to aggression. ${ }^{533}$ Similarly, although JFK valued power in instrumental terms, he did not view force, as distinct from the ends force could be tasked to serve, as glorious or noble.

JFK was a cognitively complex and non-ideological person who understood the complexities of foreign policy and actively solicited contrary opinions in his decisionmaking; he was the antithesis of a dogmatic. ${ }^{534}$ His statement to the captive people of West Berlin in 1961, "Ich bin ein Berliner," coupled with his great charisma, good sense of humor, and personal charm, evidence his need for affiliation and connection with others. ${ }^{535}$ Despite his lifelong poor health, and his concern that he would die at an early age from Addison's disease, ${ }^{536}$ JFK had relatively high self-esteem.

In sum, JFK scores militaristic on six of thirteen subconstructs—nationalism, FAP, patriotism, military experience, competitiveness, and ambitiousness - and thus is scored a non-militarist.

ii. anomism

Despite his general political conservatism, for JFK, law and morality were concepts applicable primarily to lesser persons. ${ }^{537}$ During his tenure in the White House, JFK's view of law and morality tended to be flexible in any circumstances. [He] also had no qualms about widespread wiretapping of his friends and enemies to plug leaks and to gather damaging evidence for use against suspected individuals. ${ }^{538}$

He was completely untroubled that his book, Why England Slept (1940), reached the best-seller list only because his father purchased the majority of the copies, nor did it disturb him that the award of the Pulitzer Prize for his book, Profiles in Courage (1953), was procured through the intervention of a journalist crony of his father and that the book itself was ghostwritten. ${ }^{539}$ Moreover, JFK took what can best be described as a very "casual view of his marriage vows[.]" A40 Although JFK did not have any formal legal training, he was advised by his brother, Robert, whom he appointed Attorney General. There is no evidence that either had any specific legal training in IHL.

In sum, JFK scores high on all five subconstructs of anomism and thus is scored an anomist. iii. hostility

As his wiretapping of friends and foes alike evidences, ${ }^{541}$ JFK was a deeply suspicious person who was "fascinat[ed] . . with sinister gimmicks and trickery as tools of presidential action., Moreover, he was a "deeply hedonistic" and self-centered person who viewed others, particularly women, as objects to satisfy his needs. ${ }^{543}$ Although his high need for affiliation mitigated any tendency toward misanthropy, his experiences with Soviet leader Nikita Khruschchev and Cuban President Fidel Castro

\footnotetext{
${ }^{533}$ GREENSTEIN, supra note 227, at 61-64; see also ROBERT F. KENNEDY, THIRTEEN DAYS 155 (stating that JFK adhered to the lesson, learned by the world after the Munich appeasement of Hitler, that "[a]ggressive conduct, if allowed to grow unchecked and unchallenged, ultimately leads to war.")

${ }^{534}$ See generally GEORGE, supra note 247.

${ }^{535}$ VALENTY \& FELDMAN, supra note 226, at 163-75; GREENSTEIN, supra note 227, at 69 (noting that JFK studied and remembered the names of journalists and disarmed his critics with charm).

${ }^{536} \mathrm{Id}$. at 72 .

${ }^{537}$ See GREENSTEIN, supra note 227, at 61 (describing JFK as a political conservative).

${ }^{538}$ GOULD, supra note 497, at 134.

${ }^{539} \mathrm{Id}$. at 136.

${ }^{540} \mathrm{Id}$. at 130.

${ }^{541}$ See supra at note_.

${ }^{542}$ GOULD, supra note 497, at 133.

${ }^{543}$ GREENSTEIN, supra note 227, at 59.
} 
exacerbated his cynicism and distrust and his sense that Communism, and communists, were invariably hostile to him personally and the free world more generally, and he developed the firm conviction that "any means was justified to bring down [Castro]." ${ }^{, 544}$ Strangely perhaps, JFK is cited for his great capacity to empathize even with political adversaries, particularly in his conduct of the Cuban Missile Crisis ["CMC"] wherein his ability to relate to Khrushchev's concerns about U.S. missiles in Turkey and agree to a mutual withdrawal of missiles is regarded as the basis for the peaceful outcome. ${ }^{545}$ Finally, JFK's selfless bravery in rescuing his crew members after the destruction of his vessel during World War II, coupled with his commitment of the U.S. to an enormous undertaking in defense of global liberty in his Inaugural Address and subsequent policy decisions, suggest that he scores high on the altruism as well as the internationalism subconstructs.

In sum, JFK scores high on five of ten subconstructs of hostility—distrust, narcissism, cynicism, hostility, Machiavellianism — and low on five subconstructs-misanthropy, ethnocentrism, lack of empathy, selfishness, and anti-internationalism. JFK can thus be scored either as hostile or non-hostile; artful intuition counsels in favor of the former.

iv. adventurism

JFK took unwarranted risks, and psychobiographers describe him as lacking any agenda other than virulent anticommunism and the compulsive pursuit of glory. ${ }^{546}$ His response at the Bay of Pigs is generally characterized as an impulsive reaction with little forethought and little political will. ${ }^{547}$ Although his decisions during the CMC demonstrate learning, and although his advisors report that he was conscious of the desire to avoid miscalculation, he remained, in essence, a political gunslinger. ${ }^{548}$ Stress and anxiety were his constant companions: he lived under the shadow of disabling medical conditions, and "treated each day as if it were his last, demanding of life constant intensity, adventure, and pleasure." ${ }^{, 549}$ Still, JFK retained a healthy measure of optimism, and believed he could assert significant control over events provided he mustered enough energy and attention to detail. ${ }^{550} \mathrm{JFK}$ scores high on all seven subconstructs of adventurism and thus is scored an adventurist.

v. summary of independent variables: JFK

JFK was a non-militaristic yet anomistic, hostile, and adventuristic decisionmaker.

b. DVs: ASD and Cuban Missile Crisis

On 20 October 1962, the U.S., four days after acquiring credible intelligence that the Soviet

\footnotetext{
${ }^{544}$ GOULD, supra note 497, at 133; see also MICHAEL BESCHLOSS, THE CRISIS YEARS: KENNEDY AND KHRUSCHEV 458 (describing JFK as "surprised and angry" to discover that the Soviets had lied by placing missiles in Cuba).

For JFK, crises were everywhere, and communism was at the root of it all. See OFFERMAN-ZUCKERBERG, supra note 299, at 93 ("'Crisis' was a way of viewing the world for Kennedy.").

${ }^{545}$ See VALENTY \& FELDMAN, supra note 226, at 14 (making this argument); GREENSTEIN, supra note 227, at 72 ("[I]f anyone is going to write after this, they are going to understand that every effort was made to find peace and every effort to give our adversary room to move.") (quoting JFK comment to brother Robert during CMC).

${ }^{546}$ OFFERMAN-ZUCKERBERG, supra note 299, at 96 (anti-communism); VALENTY \& FELDMAN, supra note 226, at 16375 (glory).

${ }^{547}$ GREENSTEIN, supra note 227, at 67-69.

${ }^{548}$ See ROBERT F. KENNEDY, THIRTEEN DAYS 40 (1967) (noting JFK did not want to enter a war out of "wounded pride").

${ }^{549}$ GREENSTEIN, supra note 227, at 72.

${ }^{550}$ VALENTY \& FELDMAN, supra note 226, at 163-75.
} 
Union was deploying medium-range nuclear-armed missiles ninety miles from U.S. shores in Cuba, ${ }^{551}$ demanded their removal and instituted a "pacific naval blockade," an act of war under IHL, ${ }^{552}$ to prevent further shipments. During a heated debate within the JFK Administration, senior officials of the Departments of Justice and State urged JFK to claim ASD as the legal justification for the blockade and subsequent airstrikes, ${ }^{553}$ and others counseled that to mount such an argument on the basis of the facts, which in their estimation could not support a claim that an "armed attack" had occurred or that a threat to the U.S. was imminent, would be to stretch the definition of ASD beyond reasonable bounds and "trivialize the whole effort at legal justification." $" 544$ Although opponents of ASD could not convince JFK that the presence of missiles in Cuba did not constitute an imminent threat as a matter of policy, ${ }^{555}$ they prevailed on the question of legal justification, and JFK characterized the blockade not as an act of ASD under Article 51 but rather as regional action authorized by the Organization of American States ${ }^{55}$ under Articles 52 and 53 of the UN Charter ${ }^{57}$ and justified under his constitutional "duty to defend the security

\footnotetext{
${ }^{551}$ The U.S. Ambassador to the UN, Adlai Stevenson, produced photographic and documentary evidence establishing for the the Security Council the "smoking gun" that proved the presence of Soviet missiles in Cuba and established the factual predicate for U.S. actions during the Cuban Missile Crisis. KENNEDY, supra note 549, at 23, 105-10.

${ }_{552}^{5}$ See Radio-TV Address of the President to the Nation from the White House (Oct. 22, 1963) (announcing the blockade).

${ }^{553}$ See Memorandum for the Attorney General, from Norbert A. Schlei, Assistant Attorney General, Office of Legal Counsel, Re: Legality under International Law of Remedial Action Against Use of Cuba as a Missile Base by the Soviet Union (Aug. 30, 1962), at 2 ("The concept of self-defense in international law of course justifies more than activity designed merely to resist an armed attack which is already in progress. Under international law every state has, in the words of Elihu Root, 'the right ... to protect itself by preventing a condition of affairs in which it will be too late to protect itself."'). For many administration officials, the presence of Soviet missiles a scant 90 miles from the U.S. transformed the relative capability of the Soviet Union so radically that this fact, standing alone, constituted a threat of such imminence that any proportional exercise of force would have been a permissible act of ASD under any legal standard. See McGEORGE BUNDY, DANGER AND SURVIVAL 398 (1989) (describing views of Secretary of State Acheson and others). Interestingly, even those administration officials who favored the blockade and airstrikes and would have defended these uses of force as legitimate acts of ASD considered providing limited advance warning to allies as well as target states on the belief that failure to do so would cause the U.S. to be "marked as a reckless aggressor and this Administration cursed forever as the force which opened the door to a world of catch-as-catch-can violence." See LAURENCE CHANGE \& PETER KORNBLUTH (EDS.), THE CUBAN MISSILE CRISIS: A NATIONAL SECURITY ARCHIVE DOCUMENTS READER 128-32 (1992) (reprinting a declassified document entitled "Air Strike Scenario for October 19, 1962"). In other words, proponents of ASD in the context of the CMC recognized the obligation to justify its application lest failure to do so carry adverse legal and political consequences.

${ }_{554}$ ABRAM CHAYES, THE CUBAN MISSILE CRISIS 65-66 (1974). For Chayes and others, including a number of officials from the State Department, the Soviet deployment of missiles was not only not an imminent threat, it was not illegal, and to interpret their deployment as an armed attack to satisfy the requirements of Article 51 was simply unsustainable. See JAMES G. BLIGHT \& DAVID A. WELCH, ON THE BRINK: AMERICANS AND SOVIETS REEXAMINE THE CUBAN MISSILE CRISIS 40 ("[O]ur legal problem was that their [the Soviets] action wasn't illegal[.]”). Thus, to have asserted the doctrine of ASD under circumstances where not only could no objective imminent threat be openly identified but the action that would be claimed as haven given rise to an imminent threat was considered legal would have been to withdraw entirely the use of force in self-defense from the realm of international law:

No doubt the phrase "armed attack" must be construed broadly enough to permit some anticipatory response. But it is a very different matter to expand it to include threatening deployments or demonstrations that do not have imminent attack as their purpose or probable outcome. To accept that reading is to make the occasion for forceful response essentially a question for unilateral national decision that would not only be formally unreviewable, but not subject to intelligent criticism, either .... Whenever a nation believed that interests, which in the heat and pressure of a crisis it is prepared to characterize as vital, were threatened, its use of force in response would become permissible. In this sense, I believe an Article 51 defense would have signaled that the United States did not take the legal issues involved very seriously, that in its view the situation was to be governed by national discretion, not international law.

Id.

${ }^{555}$ See John Yoo, International Law and the War in Iraq, 97 AM. J. INT'L L. 563, 573 (2003) (noting that during the CMC the near-consensus among senior U.S. officials was that establishment of nuclear-armed missile bases in Cuba by the USSR constituted an imminent threat to U.S. security even absent proof of an "imminent" threat under the Caroline standard).

${ }^{556}$ The Organization of American States is a regional organization created in 1948 under Chapter VIII of the UN Charter. See CHARTER OF THE ORGANIZATION OF AMERICAN STATES (1948). On October 23, 1962, a resolution of the OAS General Assembly authorized member states to participate in the blockade of Cuba.

${ }^{557}$ Sapiro, supra note 457, at 601 . Article 52 recognizes the existence of regional organizations with mandates for the maintenance of regional peace and security. UN Charter, supra note 440, at Art. 52 . Article 53 contemplates that Article 52 regional organizations may take enforcement action with the authorization of the Security Council. Id. at Art. 53.
} 
of the United States" ${ }^{, 58}$ and to prevent a foreign power from extending its sphere of influence. ${ }^{559}$

In subsequent days the Security Council staged a parallel debate along Cold War lines over whether the blockade could be justified as a lawful act of ASD rather than an unlawful act of aggression. ${ }^{560}$ The expressed U.S. justification was largely ignored, reflecting the broad understanding that ASD provided the more legitimate, or even the sole defensible, position. A number of states expressed strong opposition, alleging that the U.S. had adduced insufficient proof that the missiles had been emplaced for offensive purposes to meet the imminence threshold necessary to permit the exercise of $\mathrm{ASD}^{561}$ and that, as a consequence, the blockade was an unlawful exercise of force in violation of Article 2(4). Others reached the opposite conclusion, judging the blockade a lawful act of ASD in response to an imminent threat posed by offensive missiles. ${ }^{562}$ Despite the intensity of the debate, however, the Security Council took no action, ${ }^{563}$ a fact U.S. officials interpreted as implied authorization for the resort to ASD. ${ }^{564}$ On October 28, the CMC ended with a public concession by the Soviet Union promising to withdraw all missiles from $\mathrm{Cuba}^{565}$

Subsequent analysis has revealed a general agreement that the mere presence of Soviet missiles in Cuba did not constitute an imminent threat to the U.S. sufficient to satisfy the standard elaborated in the Caroline Case $^{566}$ even though the U.S. response to the CMC is "widely accepted as legitimate." reason for the apparent gap between law and legitimacy may stem from the fact that many CMC scholars read into the silence of the Security Council on the question of the legitimacy of ASD a widespread implicit endorsement not only of the U.S. naval blockade but also of a more expansive legal basis for U.S. military action in self-defense than is provided by Article $53 .{ }^{568} \mathrm{JFK}$ 's decision to institute a blockade is generally regarded as having been instrumental in forcing Khruschev to retreat from a reckless policy

\footnotetext{
${ }_{559}^{558}$ See Proclamation No. 3504, 27 FED. REG. 10,401 (1962).

${ }^{559}$ See BESCHLOSS, supra note 545, at 447 (noting that JFK referenced the Monroe Doctrine in developing his theory of legal justification for intervention in Cuba).

${ }_{560}^{5 e}$ Se ANTHONY CLARK AREND \& ROBERT BECK, INTERNATIONAL LAW AND THE USE OF FORCE 74-76 (1993) (characterizing Security Council debate over U.S. blockade as having been couched in terms of ASD).

${ }^{561}$ A bloc of states rejected the blockade as a violation of Article 2(4) not otherwise permissible under Article 51 on the ground that unless the U.S. could prove an offensive purpose for the missiles it could not demonstrate an imminent threat against which the lawful exercise of ASD could be maintained. See, e.g., U.N. SCOR, $17^{\text {th }}$ Sess.,, 1023d mtg., at 19, U.N. Doc. S/PV.1023 (1962) (statement of Quaison-Sackey, delegate of Ghana) (arguing that there was insufficient proof to conclude that the missiles had been emplaced for offensive purposes and that as a result the U.S. blockade was not in response to an imminent threat and therefor not lawful); see also Sean M. Condron, Justification for Unilateral Action in Response to the Iraqi Threat: A Critical Analysis of Operation Desert Fox, MIL. L. REV. 115, 134-35 (1999) (noting that the Soviet Union, Ghana, Romania, and the United Arab Republic led opposition to the U.S. blockade as an act of ASD).

${ }^{562}$ AREND \& BECK, supra note 561, at 75 (listing states in support of the blockade as Chile, France, Ireland, Taiwan, the United Kingdom, and Venezuela).

${ }_{563}^{563}$ The Security Council took no action in respect of the Cuban Missile Crisis. A. MARK WEISBURD, USE OF FORCE: THE PRACTICE OF STATES SINCE WORLD WAR II, 217-18 (1997).

${ }^{564}$ See Abram Chayes, Law and the Quarantine of Cuba, 41 FOREIGN AFF. 550, 556 (1963) ("[F]ailure of the Security Council to disapprove regional action amounts to authorization within the meaning of Article 53."); see also Leonard C. Meeker, Defensive Quarantine and the Law, 57 AM.J.INT'L L. 515, 522 (1963) (arguing that since the quarantine continued with the knowledge of the Security Council, "authorization may be said to have been granted[.]").

${ }^{565}$ CHANG \& KORNBLUH, supra note 554, at 347-400 (discussing the resolution of the CMC).

${ }^{566}$ See Schmitt, supra note 454, at 488-89 (concluding that the "Soviets did not deploy missiles in Cuba in order to launch a war" but rather to achieve parity with the U.S.); Roberts, supra note 8, at 528-29 (contending that the presence of Soviet missiles in Cuba "did not per se constitute a threat against the United States and the Western Hemisphere[,]" although in conjunction with other examples of Soviet brinksmanship, support for terrorism, and other acts of aggression the missiles may have been adjudged a threat, whether imminent or not).

${ }_{567}$ Wedgwood, supra note 465 , at 584.

${ }^{568}$ Several commentators have criticized the doctrine of implicit Security Council authorization of regional organizations as enforcement mechanism as inconsistent with the express terms of the UN Charter. See, e.g. (note).
} 
decision and in promoting enhanced dialogue and reduced superpower hostility. As such, the decision to engage in ASD is one that contributed to world order and that JFK would have likely have made again under identical circumstances.

3. Prime Minister Levi Eshkol and the Six Day War (1967)

a. IVs: scores on personality constructs

i. militarism

Israeli Prime Minister Levi Eshkol [“LE”] was a Zionist pioneer who dedicated his life to the enormously ambitious project of re-establishing Israel after two millennia of diaspora. Although LE served in the Jewish Legion of the British Army during World War I ${ }^{569}$ there were decided limits to his ambition, competitiveness, and militarism: compromise and finesse were his policy instruments of choice, and power was to be used only sparingly. ${ }^{570} \mathrm{He}$ was an easy-going and flexible person who would labor to avoid disagreement and "[i]n every argument made an effort to see both sides of the coin[.]" "warm and wise,",572 with a "great sense of humor," and maintaining friendships with a wide range of people. ${ }^{574}$

In sum, LE scores as militaristic on only four of ten subconstructs of militarism—nationalism, patriotism, military experience, and ambitiousness - and thus is scored a non-militarist.

ii. anomism

Available data does not offer much insight into LE's attitudes toward law and legal authority. It is likely unfair to generalize from his violation of British Mandatory arms importation restrictions prior to the War of Independence in $1948 .^{575}$ Moreover, LE had a traditonal Talmudic education and was raised by devout parents, and although he appears to have developed a more non-ideological approach ${ }^{576}$ to moral judgment than might be prescribed by his Orthodox ancestry ${ }^{577}$ he remained dedicated to being perceived personally, and to having Israel perceived, as "one of the good guys." ${ }^{, 578}$ He had no formal legal training. In sum, LE scores high on only two of five subconstructs of anomism-ignorance of law and ignorance of IHL-and thus is scored a non-anomist.

iii. hostility

Although the Russian pogroms "hung over [his] head all the time[,]" ${ }^{\text {,579 }}$ LE treated others as worthy of his trust until he had reason to believe otherwise, and as ends rather than as means. ${ }^{580}$ His

\footnotetext{
${ }^{569}$ TERENCE PRITTIE: ESHKOL: THE MAN AND THE NATION 39 (1969).

${ }^{570}$ See SHIMON PERES, SEVEN FOUNDERS OF THE STATE OF ISRAEL 79-80 (1968) (describing LE as "flexible", dedicated to the "art of compromise[,]" and convinced that "without compromise life is impossible[.]"); PRITTIE, supra note 570 , at 39 (stating that LE "recoiled from militarism").

${ }^{571}$ PERES, supra note 571, at 103.

${ }^{572}$ MICHAEL B. OREN, SIX DAYS OF WAR 98 (2002).

${ }^{573}$ PERES, supra note 571 , at 79-80.

${ }^{574}$ Id. at 90; PRITTIE, supra note 570, at 206.

${ }^{575}$ See http://www.israel.org/mfa/go.asp?MFAH00fr0 (last visited Ap. 17, 2004); PRITTIE, supra note 570, at 54-55 (describing LE's 1921 arrest by the British for gunrunning).

${ }^{576} I d$. at 13 (describing LE as a non-ideologue).

${ }^{577}$ See supra at note 572 (discussing his flexibility and capacity to see and empathize with every point of view).

${ }^{578}$ OREN, supra note 573 , at 123.

${ }^{579}$ PRITTIE, supra note 570, at 4.

${ }^{580}$ See PERES, supra note 571.
} 
capacity to empathize and sacrifice his own interests for the benefit of others are well-chronicled, ${ }^{581}$ as is his commitment to constructive engagement with other states on behalf of his embattled nation. ${ }^{582}$ LE thus scores as hostile on none of the subconstructs of hostility and is scored as non-hostile.

iv. adventurism

LE was highly risk-averse and indecisive. ${ }^{583}$ Although he was comfortable in most social situations, ${ }^{584}$ the demands of crisis decisionmaking filled him with anxiety and rendered him, to some degree, paralyzed by fear of failure. ${ }^{585}$ Although he was optimistic generally, and although he remained outwardly calm, ${ }^{586}$ under conditions of high stress LE was decidedly pessimistic and fatalistic. ${ }^{587}$ In sum, LE scores as adventuristic on only three of seven subconstructs of adventurism-anxiety, stress, and male sex-and thus scores as a non-adventurist.

v. summary of independent variables: LE

LE is a non-militaristic, non-anomistic, non-hostile, and non-adventuristic decisionmaker.

b. DV: ASD and the Six Day War

In May 1967, President Gamal Abdel Nasser of Egypt, after months of hostile public statements expressing an intent to destroy Israel, ${ }^{588}$ evicted the UN Emergency Force in Sinai, ${ }^{589}$ closed the Gulf of Aqaba and the Straits of Tiran to Israeli shipping, ${ }^{590}$ and deployed Egyptian forces in an offensive posture on maximum alert status near the Israeli border. Although Egypt conceded that the closure of the waterways was a belligerent act, Nasser justified the measure on the ground that Israel and Egypt had continued in a state of war since 1948 and that either party could engage in belligerency without altering the legal status quo. ${ }^{591}$ In response, LE, although he still believed Nasser did not intend war but merely wished to enhance his pan-Arab credentials by blustering against Israel, ${ }^{592}$ warned that Israel would regard the re-opening of the waterways as an act of self-defense. ${ }^{593}$ In turn, Egypt defended the closure as an act oriented toward ensuring the right of the Palestinian people to self-determination. ${ }^{594}$ While Israel

\footnotetext{
${ }^{581}$ See, e.g., id.; PRITTIE, supra note 570, at 117 (describing LE's great concern for and efforts on behalf of workers in his capacity as Secretary General of the Tel Aviv Labor Council); id. at 185 (describing LE's gift for "understanding what was in a simple man's mind, talking about it with him as an equal, making him feel that he mattered.").

${ }^{582}$ See infra at pp._ (discussing LE's efforts to secure diplomatic support for Israeli in the weeks before the Six Day War).

${ }^{583}$ PERES, supra note 571, at 103; PRITTIE, supra note 570, at 183 (referencing jokes about LE as indecisive, such as that he was a man whose slogan was, "Don't postpone until the morrow what can be postponed until the day after tomorrow").

${ }^{584}$ PERES, supra note 571 , at 80.

${ }^{585}$ See OREN, supra note 573, at 89 (describing LE's near emotional collapse in late May 1967).

${ }^{586}$ PRITTIE, supra note 570, at 105.

${ }^{587}$ See PERES, supra note 571, at 109 (describing LE's general optimism as limited to routine conditions).

${ }^{588}$ NADAV SAFRAN, FROM WAR TO WAR: THE ARAB-ISRAELI CONFRONTATION, 1948-1967 268 (1969).

${ }^{589}$ Special Report of the Secretary-General, U.N. Doc. A/6669, at 1 (1967); Report of the Secretary-General on the Situation in the Near East, U.N. SCOR, 22d Sess., U.N. Doc. S/7896 (1976).

${ }^{590}$ See id. at S/7906.

${ }^{591}$ See Comment, The Arab-Israeli War and International Law, 9 HARV. INT'L L. J. 232, 245 (1968) (recounting the Egyptian legal justification for the closure of the waterways and the eviction of UN forces in Sinai).

${ }^{592}$ See OREN, supra note 573, at 76-77 (stressing, however, that other members of his Cabinet were convinced that war was inevitable); see also id. at 83 (noting even Nasser calculated the probability of war as greater than 50 percent in late May).

${ }^{593}$ See SAFRAN, supra note 589, at 269 ("Any interference with freedom of shipping in the Gulf and in the Strait constitutes a gross violation of international law, a blow at the sovereign rights of other nations, and an act of aggression against Israel.") (statement of Prime Minister Eshkol). IDF Chief of Staff Yitzhak Rabin finalized plans for ASD against Egypt, code-named OPERATION MOKED, in late May. OREN, supra note 573, at 79.

${ }^{594}$ See AL AHRAM (Cairo), May 30, 1967 ("The issue today is not the question of Aqaba, or the Strait of Tiran, or U.N.E.F. The issue is the rights of the people of Palestine, the aggression against Palestine that took place in 1948, with the help of Britain and the United States.... [Others] want to confine [the conflict] to the Strait of Tiran, U.N.E.F., and the rights of passage. We say: We want the rights of the people of Palestine--complete.") (statement of President Nasser to Egyptian National Assembly); see also U.A.R. Statement on Withdrawal of U.N.E.F. and Closing of Strait of Tiran to Israeli Ships, in part reprinted in 6 I.L.M. 573
} 
dispatched emissaries to Western capitals to seek diplomatic assistance to resolve the brewing crisis, ${ }^{595}$ Egypt incorporated the armed forces of Syria, Jordan, and Iraq under its unified command and began flying combat air patrols in Israeli airspace. ${ }^{596}$

In the last days of May and the first weeks of June, a bitter schism divided the Israeli government. $^{597}$ One camp, led by the IDF, was adamant that unless ASD was immediately employed against Egypt, Israeli survival was in jeopardy. ${ }^{598}$ A second, consisting almost exclusively of LE and a few aides, refused to approve ASD until efforts to secure diplomatic support had been exhausted and Israel could ensure "that the world knows that [sh]e waited long enough." in the U.S. and Europe were rebuffed did LE conclude that Israel could make this case. ${ }^{600}$ On the morning of June 5, 1967, Israel launched a decisive air campaign against the air forces of the UAR Unified Command, to which the Arab states, despite suffering complete tactical surprise and the destruction of their air forces, responded by attacking with ground forces across their borders with Israel. In subsequent days Israel defeated combined Arab ground forces and captured the Sinai Peninsula, the West Bank, and the Golan Heights, and by June 10 all parties had accepted a ceasefire. ${ }^{601}$ An intra-cabinet debate over whether to claim that Egypt had initiated hostilities was resolved in favor of the truth. ${ }^{602}$

In the aftermath of the brief but decisive conflict, Israel justified its attack under Article 51 in part on the premise that the closure of the Straits of Tiran constituted an "armed attack" justifying force in self-defense ${ }^{603}$ and in part on the basis that the presence of the troops of a hostile state on its southern border, coupled with the clearly expressed intent of that state to destroy Israel and convincing intelligence that an Egyptian attack was imminent, posed a serious and imminent threat to its national security justifying the exercise of ASD. ${ }^{604}$ The ensuing debate within the Security Council largely rejected the former argument and centered upon the reasonableness of the Israeli attack, inquiring whether under the circumstances the threat could have been considered sufficiently imminent to dispatch with the

(1967) (excerpting speech by Nasser to UAR Air Force Advanced Command, May 22, 1967, and defending actions as on behalf of Palestinian people).

${ }^{595}$ SAFRAN, supra note 589, at 269.

${ }^{596}$ See id. at 269 (reporting that Algerian, Kuwaiti, Libyan, and Sudanese units were placed under UAR operational control).

${ }^{597}$ For a discussion of the battle within the Israeli politico-military leadership, see PRITTIE, supra note 570, at 250-59.

${ }^{598}$ See OREN, supra note 573, at 86 (quoting IDF Chief of Staff Yitzhak Rabin as stating that as of late May 1967 "it was now a question of our national survival, of to be or not to be[.]"); id. at 133 (noting IDF predictions that absent an exercise of ASD, Egypt would attack Israeli population centers with CWs and radioactive weapons). Many Israelis were convinced that LE, by failing to strike, was "playing the role of a Neville Chamberlain[.]" PRITTIE, supra note 570, at 275.

${ }^{599}$ OREN, supra note 573 , at 156.

${ }^{600}$ See id. at 77 (stating that the U.S. failure to provide security guarantees convinced LE ASD was necessary). President Johnson told Israeli Ambassador Abba Eban only that "Israel will not be alone unless it decides to go it alone" and provided no specific guarantee. Id. at 103. Despite U.S. unwillingness to support Israel, Undersecretary of State Eugene Rostow advised Israeli diplomats that ASD would be a "horrendous error." Id. at 108. French President de Gaulle was even more blunt, advising that if Israel resorted to ASD France would condemn her. Id. at 101.

${ }^{601}$ For a detailed discussion of the Six Day War, see GEORGE LENCZOWSKI, A CONCISE HISTORY OF THE MIDDLE EAST ( $4^{\text {th }}$ ed. 1995). For an examination of Israeli decisionmaking, see generally BRECHER, supra note 261.

${ }^{602}$ OREN, supra note 573 , at 169.

${ }^{603}$ Some commentators have suggested that the Israeli justification for the use of force was that the closure of the Straits of Tiran constituted an "armed attack" for purposes of self-defense under Article 51. See, e.g., Sapiro, supra note 457, at 601 (listing commentators). See Condron, supra note 562, at 136 (initially implying the opposite but then concluding the Israeli use of force constituted ASD).

${ }^{604}$ From the Israeli perspective the Six Day War was one of ein breaira ("no alternative") as the survival of the state was in jeopardy had Israel not chosen to engage in ASD. See AVRAHAM TAMIR, A SOLDIER IN SEARCH OF PEACE: AN INSIDE LOOK AT ISRAEL'S STRATEGY 171 (1988) (relating the Israeli perspective in the days before June 5, 1967). 
requirement of an "armed attack" as a condition precedent to self-defense. ${ }^{605}$ As might have been expected during the height of the Cold War, the Soviet Union and its Arab clients steered the discussion away from the threat Egypt and Syria had posed to Israel and focused formalistically on the text of Article 51, defining the Israeli action as ipso facto illegal aggression in violation of Article 2(4) by virtue of the fact that Israel had been first to resort to the overt use of force. Predictably, the Russo-Arabic bloc categorically refused to engage on the question of the availability of ASD. ${ }^{606}$ In contrast, although little serious consideration was paid to the argument that the closure of the Straits of Tiran constituted an "armed attack," the U.S. and other Western states defended the Israeli position that the imminence and magnitude of the threat justified the exercise of ASD, and this bloc shielded Israel from adverse legal judgment: although the Security Council did not make an official pronouncement upon the legitimacy of ASD in context, none of the three Resolutions that emerged from the aftermath of the Six Day War condemned Israeli actions. ${ }^{607}$

Although the question of whether the threat to Israel was in fact sufficiently imminent to justify ASD remains the subject of legal and political wrangling, most commentators view the Israeli claim that the threat justified the response to be reasonable. ${ }^{608}$ More importantly, commentators generally read into Security Council silence on the legitimacy of the Israeli ASD argument implicit support for the proposition that the right to ASD continues in force under the customary international law of the Charter era, particularly where the survival of a state is arguably at issue. ${ }^{609}$ Had LE not ordered ASD, it is likely that Israel would have ceased to exist and that the second Holocaust promised by Nasser would have materialized, ${ }^{610}$ and it is inconceivable that LE would have considered, in retrospect, that he had made anything other than the proper decision.

4. Prime Minister Golda Meir and the October War (1973)

a. independent variables: scores on personality constructs

i. militarism

\footnotetext{
${ }^{605}$ U.N. SCOR, 22d Sess., 1348th mtg., U.N.Doc. S/PV/1348 (1967).

${ }^{606}$ See AREND \& BECK, supra note 561, at 77 (noting that the Russo-Arabic position was reducible to the argument that the first use of force was aggression regardless of the circumstances prompting that use of force).

${ }^{607}$ See S.C.Res. 233, U.N. SCOR, 22d Sess., 1348th mtg. at 1-2, U.N.Doc. S/7935 (1967); S.C.Res. 234, U.N. SCOR, 22d Sess., 1350th mtg. at 2, U.N.Doc. S/7941 (1967); S.C.Res. 235, U.N. SCOR, 22d Sess., 1352d mtg. at 4, U.N.Doc. S/7960 (1967). Moreover, a Soviet-sponsored resolution that would have condemned Israel was defeated in the Security Council and the General Assembly. See U.N. SCOR, 22d Sess., 1351st mtg. at 5, U.N.Doc. S/7951 (1967); U.N. GAOR, 5th Emergency Special Sess., 1548th mtg., at 171, U.N.Doc. A/PV.1525-1559 (1967).

${ }^{608}$ See Beth Polebaum, National Self-Defense in International Law: An Emerging Standard for a Nuclear Age, 59 N.Y.U. L. REV. 187, 194 (1984) ("Most commentators concluded that Israel's belief that it was about to be attacked on all its borders was reasonable."). For a defense of the factual predicate giving rise to the Israeli claim, see Amos Shapira, The Six-Day War and the Right of Self-Defense, 6 ISR. L. REV. 65, 73-75 (1971) (contending that Israel was faced with imminent attack). For a counterargument, see M. Cherif Bassiouni, The Middle East: The Misunderstood Conflict, in THE ARAB ISRAELI CONFLICT 327, 347-50 (J.N. Moore ed., 1977) (arguing Israel committed aggression because it "started the shooting").

${ }^{609}$ See, e.g., Smith, supra note_, at 483-85 (concluding that Security Council and General Assembly refusal to condemn Israeli actions constitutes implicit affirmation of the right to ASD); Franck, supra note 465, at 12 ("In some circumstances, the Charter system has condoned a state's recourse to force to preempt an imminent attack on it; an example is the Israeli war against Egypt (1967)."); DINSTEIN, supra note 434, at 191 ("In the circumstances, as perceived in June 1967, Israel did not have to wait idly by for the expected shattering blow[.]"). Those most critical of the legality of Israeli actions of June 1967 generally contend either that the specific facts did not support ASD or that Security Council failure to expressly condemn UAR actions cannot be interpreted as condoning ASD. Richard B. Bilder \& Mary Ellen O'Connell, Review Essay: Releashing the Dogs of War (Review of Christine Gray, International Law and the Use of Force, 97 AM. J. INT'L L. 446, 453 (2003) (challenging legitimacy of Israeli actions as unsupported by proof of an imminent threat); Condron, supra note 562, at 136 (concluding that UN failure to condemn Israel leaves the legality of ASD as an "unsettled question.").

${ }^{610}$ See OREN, supra note 573, at.
} 
Israeli Prime Minister Golda Meir ["GM"] dedicated her life to the resurrection of the Israeli state and the restoration of the Jewish people to freedom and independence. ${ }^{611}$ Although she preferred negotiated compromise to blunt force,${ }^{612}$ loathed war, ${ }^{613}$ and had no understanding of martial matters, ${ }^{614}$ she was a tough authoritarian who "r[an] her Cabinet like a front-line officer, thumping the table for order, and making blunt and rapid decisions." ${ }^{\circ 15}$ GM was a highly dogmatic leader who, although she would allow others to speak, did not appreciate subtlety and would move quickly to decisions from which she was immovable. ${ }^{616}$ Despite this, however, she was a friendly and gracious extrovert whose social skills were instrumental in raising funds for the Jewish State ${ }^{617}$ and who enjoyed lifelong friendships, popularity, ${ }^{618}$ and high self-esteem. ${ }^{619}$ In sum, GM scores as militaristic on six of thirteen subconstructs of militarism—nationalism, patriotism, authoritarianism, competitiveness, dogmatism, and ambitiousnessand thus is scored as non-militaristic.

ii. anomism

Although there is little information as to whether GM was remarkable in her respect for law or her degree of moralism, as a child GM survived pogroms at the hands of the Cossacks, and from this experience developed a lifelong fear of and revulsion for authorities. ${ }^{620}$ Coupled with her lack of legal training, it is fair to conclude that GM must be scored as high on at least three of five subconstructs of anomism—lack of respect for legal authority, ignorance of law, and ignorance of IHL—and thus she is scored an anomist.

iii. hostility

After suffering persecution in Russia, it is unlikely that GM ever reacquired a significant degree of trust in others. Nonetheless, GM did not become cynical or embittered, instead remaining a simple and unaffected person who, despite her personal strength and political power, retained great compassion for and sensitivity to others. ${ }^{621}$ Moreover, although she labored tirelessly on behalf of her own ethnic and cultural group, there is no indication that she developed a sense that Jews were superior to, rather than simple the equal of, other nations, and her foreign policy orientation reflected her desire for Israel to become an enmeshed member of the international community. However, GM was well aware of the degree of hostility that others manifested towards Jews generally and Israel particularly. ${ }^{622}$ GM thus

\footnotetext{
${ }^{611}$ See PEGGY MANN, GOLDA: THE LIFE OF ISRAEL'S PRIME MINISTER 127-28 (1971).

${ }^{612}$ See id. at 231 (lauding GM's "tremendous" skill at negotiation and "realistic understanding of when and how to compromise").

${ }^{613}$ See id. at 242 (noting that GM's public addresses frequently refer to her desire for peace and her abhorrence for war); id. at 191 ("Can we envisage what a state of peace between Israel and her neighbors during the past eight years would have meant for all of us ... Substitute cooperation between Israel and her neighbors for sterile hatred and ardor for destruction, and give life and hope and happiness to all its peoples") (quoting GM address to General Assembly).

${ }_{614}$ See ABRAHAM RABINOVICH, THE YOM KIPPUR WAR 90 (2004) (stating that GM "had no idea what a division was.").

${ }^{615}$ MANN, supra note 612 , at 231.

${ }^{616}$ See id. at 231 (referring to aides' comments about her stubborness); id. at 187 (referencing her dislike for subtlety); RALPH G. MARTIN, GOLDA MEIR: THE ROMANTIC YEARS 29 (1988) (reporting description of GM by her sister as stubborn, unable to admit errors, unwilling to concede points in arguments)

${ }^{617}$ See MANN, supra note 612, at 44 (linking her success as fundraiser for Jewish National Fund with her social skills).

${ }^{618} I d$. at $70,203$.

${ }^{619}$ VERTZBERGER, supra note 248, at 174; MENAHEM MEIR, MY MOTHER, GOLDA MEIR (1983).

${ }^{620}$ MANN, supra note 612, at 10; see also MARTIN, supra note 617, at 7-8, 1516 ("It doesn't matter where it will be-it is the same story, the same story.") (quoting GM on the inevitability of state-sanctioned repression).

${ }_{621}$ See MANN, supra note 612, at 231 ("She has the best qualities of a women-intuition, insight, sensitivity, compassion-plus the best qualities of a man — strength, determination, practicality, purposefulness." (quoting Simcha Dinitz).

${ }^{622}$ See MARTIN, supra note 617, at 6. 67-68 (describing GM as particularly sensitive to and aware of anti-Semitism).
} 
scores as high on only two subconstructs of hostility—distrust and hostility—and thus is scored as nonhostile.

iv. adventurism

GM disliked risk, and dreaded accession to the office of Prime Minister where she would be obligated to make momentous decisions: on becoming Prime Minister, she conceded that

I have always carried out the missions the state placed on me, but they have always been accompanied by a feeling of terror. The terror exists now. ${ }^{623}$

GM was a deliberate and cautious decisionmaker who believed that if she worked hard enough she could be successful, ${ }^{624}$ and yet she carried around a sense of pessimism and fatalism that pervaded her administration. GM often vented her emotions under the tremendous strain of her responsibilities. ${ }^{625}$ In sum, GM scores as high on only three of seven subconstructs of adventurism-internal locus of control, anxiety, and stress - and thus is scored a non-adventurist.

v. summary of independent variables: GM

GM is anomistic yet non-militaristic, non-hostile, and non-adventuristic.

b. dependent variables: ASD and the October War

After six years of low-intensity conflict post-Six Day War, tensions began to build in the early autumn of 1973, and Egypt stealthily began to deploy forces into the Sinai toward the Bar-Lev Line, the series of Israeli fortified positions constructed after the Six Day War to deter Egyptian aggression. Syria accelerated military mobilization simultaneously. By late September, Israeli intelligence was reporting plans for a Syrian attack in the Golan Heights, Israel and Syria had begun to escalate an ongoing aerial war, ${ }^{626}$ and evidence was beginning to mount of a planned Egyptian strike. ${ }^{627} \mathrm{GM}$, "confident that Israel's geopolitical situation had never been better, ${ }^{\prime}{ }^{28}$ after its overwhelming strategic victory of combined Arab armies in 1967 and advised by her senior military commanders that the chance of war with Egypt was "very low" ${ }^{\prime 629}$ but that if war came Israel would so decisively defeat her adversaries that "they'll need five years to lift their heads up again," ${ }^{630}$ did not respond to the Egyptian and Syrian mobilization. GM is also reported to have commented that "there is always the possibility that [Israel] will need help, and if we strike first, we will get nothing from anyone. ${ }^{, 631}$

At 2:30 A.M. on October 5, 1973, a Mossad agent reported that Egypt and Syria were going to initiate war in the "late afternoon" the next day, and at a cabinet meeting that morning Chief of Staff Dan Elazar, having already sent out orders to the IDF to prepare to engage Egypt and Syria, recommended that Israel engage in ASD in order to enhance the chance for survival and reduce casualties, ${ }^{632}$ while Minister of Defense Moshe Dayan counseled in favor of a limited mobilization on the ground that a preemptive

${ }^{623}$ Cited in MANN, supra note 612 , at 230.

${ }^{624}$ Id. at 265.

${ }^{625} \mathrm{Id}$. at 223 (noting that GM would not infrequently cry in public).

${ }^{626}$ RABINOVICH, supra note 615 , at 51.

${ }^{627}$ See id. at 67-70 (presenting and evaluating evidence).

${ }^{628} \mathrm{Id}$. at 11 .

${ }^{629}$ See id. at 23 (citing the assessment of Israeli intelligence as to war with Egypt); see also id. at 56-61 (discussing internal analysis of raw intelligence and debate over its significance within Israeli military intelligence).

${ }^{630} I d$. at 41 (quoting IDF Chief of Staff Elazar).

${ }^{631}$ SYDNEY BAILEY, FOUR ARAB-ISRAELI WARS AND THE PEACE PROCESS 307 (1990) (quoting GM). 
strike would portray Israel as the aggressor. ${ }^{63} \mathrm{GM}$, hoping diplomacy would avert war and that if the Arab states recognized they had lost the element of surprise they would not carry out their plans, and convinced that if Israel struck first "we won't get help from anybody," and Syria through the U.S. advising that Israel would not engage in ASD but would meet and defeat an Arab attack. ${ }^{635}$ Expecting to continue the discussion on October $8^{\text {th }}$ after Yom Kippur, the meeting adjourned.

By the next day it was too late. Egypt launched OPERATION BADHR and Syria initiated OPERATION AL AWDA in the afternoon of October $6^{\text {th }}$, and by October $8^{\text {th }}$ Arab armies were advancing and Israeli commanders were considering abandoning front-line defenses for fallback positions. ${ }^{636} \mathrm{GM}$ was so despondent over the news that she contemplated suicide. ${ }^{637}$ By the end of the week Israel had turned the tide and staved off defeat, yet lthough she was absolved of responsibility for the near-disaster by the Agranat Commission in 1974, GM resigned as a consequence of the political fallout of her mistaken decisionmaking during the October War and left public life embittered. ${ }^{638}$ In retrospect, the failure to preempt Egyptian and Syrian threats was a cataclysmic error that, but for U.S. intervention on behalf of Israel, might have spelled the end of the Jewish state.

d. Prime Minister Menahem Begin and the Strike on Osiraq (1981)

a. independent variables: scores on personality constructs

i. militarism

Israeli Prime Minister Menahem Begin ["MB"] was a "deeply nationalistic" person whose political identity was shaped by his study of Zionist philosophers Theodor Herzl and Vladimir Jabotinsky. ${ }^{639}$ Power was not only the primary currency of his brand of Zionism but something to be hoarded and used in self-defense: MB was an aggressive force behind a new ideology of the Jews as a people who fought back against oppression rather than accepting their lot. ${ }^{640}$ According to MB,

From time to time [bullies] descended on me at school, but I learned to defend myself. I never bowed my head. If someone raised his hand to me, I paid him in the same coin. There were times when I cam home bruised and bloodied — but with the feeling that my honor was intact. As time went by I learned that the ones who hit me treated me with respect when I hit back. They learned their lesson. ${ }^{641}$

In short, MB “truly believe[d] that Israel's enemies w[ould] respect her only if they respect[ed] and recognize[d] her power." ${ }^{\circ 42}$

In Palestine, MB joined the Irgun Zvi Leumi [“IZL”], an extremist paramilitary group opposed to British mandatory power, and led a series of missions at great personal risk to pressure the British and the

${ }^{632}$ See RABINOVICH, supra note 615, at 89 (noting that Elazar played upon GM's "extreme sensitivity to casualties").

${ }^{633}$ See WALTER BOYNE, THE TWO O'CLOCK WAR 26 (2002) (describing debate at 5 October cabinet meeting);

RABINOVICH, supra note 615, at 87 ("We're in a political situation in which we can't do what we did in 1967.") (quoting

Dayan on October $\left.6^{\text {th }}\right)$.

${ }^{634}$ Id. at 89 (quoting GM).

${ }^{635} I d$. at 76; BOYNE, supra note 634, at 28.

${ }^{636}$ RABINOVICH, supra note 615, at 219.

${ }^{637}$ Id. at $219-20$

${ }^{638}$ EITAN HABER, MENAHEM BEGIN: THE LEGEND AND THE MAN 295 (L. Williams trans. 1978).

${ }^{639} I d$. at 22-26.

${ }^{640}$ See ERIC SILVER, BEGIN: THE HAUNTED PROPHET 8 (1984) (“The defencelessness [sic] of the Jews [is] the real scourge of our life, for centuries ... That must never happen again.”) (quoting MB).

${ }^{641}$ HABER, supra note 639, at 29.

${ }^{642} I d$. at 25. 
Palestinian Arabs to quit the country ${ }^{643}$ For MB "conflict was essential to political transformation." Moreover, MB was the paradigmatic dogmatist who could not be dissuaded from preconceptions, ${ }^{645}$ and human relationships were valuable to him only instrumentally. ${ }^{646} \mathrm{He}$ was an insensitive and authoritarian leader and father ${ }^{647}$ who suffered from low self-esteem. ${ }^{648}$

MB scores as militaristic on all subconstructs of militarism and is thus scored a militarist.

ii. anomism

In reprisal for the execution of IZL guerrillas convicted of terrorism, MB, who attended law school at Warsaw University in the $1930 \mathrm{~s}^{649}$ and was familiar with IHL, ${ }^{650}$ ordered the abduction and hanging of captured British soldiers, an act he knew was illegal but which he justified out of necessity:

I understand only too well the feelings of the ... families [of hung British POWs], but what choice did we have? We were in the midst of a war for our liberation. The British regime threw its full military might against us. They treated our fighters as if they were common criminals instead of prisoners of war. When they sentenced men to death, we warned them that we would answer in kind. ${ }^{651}$

Despite his demonstrated lack of respect for law and legal authority, MB had a coherent internal moral code that prescribed, in effect, "an eye for an eye, and defend one's honor no matter what the price." He was an observant Jew who placed his faith before most other considerations. ${ }^{653}$ Moreover, MB believed that the Jews had a "natural right" to the land of Israel ${ }^{654}$ and that any activities in support of this right had divine imprimatur. ${ }^{65}$

MB scores as high on three of five subconstructs of anomism—disrespect for law, disrespect for legal authority, and moralism—and thus scores as an anomist.

iii. hostility

During World War I, Cossacks burned down the Begin family home, ${ }^{656}$ and the experience of pogroms and the Holocaust taught MB about the depths to which some would sink in expressing their antisemitism. Although MB is not described in terms that would suggest any narcissism, he was just

\footnotetext{
${ }^{643}$ Id. at 143; see also id. at 255 ("I cannot forget the little I know of [MB's] activity ... the murder of scores of Jews, Arabs, and Englishmen in the demolition of the King David Hotel; the pogrom in Dir Yassin[.]") (quoting David Ben-Gurion, the first Israeli Prime Minister).

${ }^{644} \mathrm{Id}$. at 50 .

${ }^{645} I d$. at 276 (reporting that "nobody could change [MB's] mind"); id. at 284 (relating MB's pronouncement that he would "cut off his right hand" before he would restore territory captured from Israel's enemies).

${ }^{646} \mathrm{Id}$. at 227.

${ }^{647} I d$. at 45, 239 (describing MB as anti-democratic" and "dangerous"); id at 300 (describing MB as a very strict father).

${ }^{648}$ See NED TEMKO, TO WIN OR TO DIE: A PERSONAL PORTRAIT OF MENACHEM BEGIN 17 (1987) (noting that MB "ached to be liked" but "expected rejection" and "ended up a recluse" and an "object of pity"); id. at 297 (MB was a "hurt, insecure, angy shtetl Jew—an ugly child, a weakling, and a loner forced to find ways to prevail.").

${ }^{649}$ HABER, supra note 639 , at 37.

${ }^{650}$ See TOMKO, supra note_, at 93, 102-03 (reporting that MB was adamant that, despite his bombing of the King David Hotel in Jerusalem in 1946 "the rules of Land Warfare . . . had been observed" inasmuch as the IZL gave short notice beforehand but that following British executions of captured IZL soldiers MB informed his forces they were "no longer ... bound by the normal rules of warfare").

${ }^{651}$ Cited in HABER, supra note 639, at 178; see also SILVER, supra note 641, at 65-76 (discussing MB's anti-British activities). ${ }^{652}$ HABER, supra note 639, at 29.

${ }^{653}$ See id. at 20 (relating that as a high school student MB failed Latin, a subject in which he excelled, because his teacher would not let him observe the Sabbath on which day the exam was scheduled); see also SILVER, supra note 641, at 6 (describing MB as an "Orthodox, but not a strictly observant, Jew.").

${ }^{654}$ HABER, supra note 639, at 201.

${ }^{655}$ Id. at 255 (quoting David Ben-Gurion as stating that MB would "sanctif[y] all means for the sake of the sacred end" of Israeli security).

${ }^{656}$ Id. at 17.
} 
short of clinically paranoid ${ }^{657}$ and plainly cynical about the motivations of people in general. ${ }^{658}$ Moreover, MB was given to ethnocentric bias in his dislike and even hatred of certain groups, including Germans, in reference to whom he remarked that "[e]very German is a Nazi" and a "murderer," described as "no less evil than . . Hitler." ${ }^{660}$ Former Israeli Prime Minister David Ben-Gurion in 1963 unequivocally declared $\mathrm{MB}$ an amoral misanthrope:

Begin is clearly a Hitlerist type. He is a racist willing to destroy all the Arabs for the sake of the completeness of the country, sanctifying all means for the sake of the sacred end-absolute rule. I see in him a severe danger to the internal and external situation of Israel ... These are not isolated acts, but a revelation of method, character, and aspiration. ${ }^{661}$

Whether this is the hyperbole of a political opponent is uncertain; nevertheless, MB, a hostile and belligerent Zionist, was plainly neither empathetic, altruistic, nor a committed internationalist. In sum, MB scores high on all subconstructs of hostility save for narcisissm; he is thus scored as hostile.

iv. adventurism

As his years in the IZL make manifest, MB accepted risk as inherent in the project of political transformation. His willingness to do so may have been a function of his optimism and his belief that, because he was engaged in a noble effort - the salvation of his nation and the performance of justice on earth-he could not fail, and thus what appeared as dangerous was in fact not truly so. ${ }^{662}$ Although MB experienced anxiety when contemplating the prospect that Arab states were scheming to attack Israel and that failure to preempt Arab plans might prove catastrophic, ${ }^{663}$ he planned strategy carefully, and when he engaged in ASD he did so with much forethought. ${ }^{664}$ In sum, MB scores high on all but one subconstruct of adventurism—impulsivity—and thus is scored an adventurist.

v. summary of IVs: MB

MB is scored as a militaristic, anomistic, and hostile adventurist.

b. DV: ASD and the Strike on Osiraq

By spring 1981, Iraq, with French assistance, was nearing completion of its Osiraq nuclear reactor facility, a project which, although the Hussein government publicly claimed it would be dedicated to peaceful research only, Israeli intelligence claimed to be a nuclear weapons production facility. ${ }^{665}$ When several months of Israeli efforts to alert the international community to the brewing danger and to secure condemnation of the Iraqi attempt to acquire WMD were unsuccessful, Israel responded with military force. At sunset on June 7, 1981, 8 Israeli F- 16 aircraft accompanied by six F-15 escorts destroyed the Osiraq nuclear reactor with twelve two thousand pound bombs shortly before it could

\footnotetext{
${ }^{657}$ See id. at 29 (suggesting that MB, just as most Israelis, suffered from collective paranoia in part as a result of the historical experience of oppression and in part as a reflection of being bullied in Polish schools).

${ }^{658}$ See YEHOSHAFAT HARKABI, ISRAEL'S FATEFUL HOUR 108 (1988) (labeling MB an extreme Machiavellian who transcends mere "dishonesty [and] demagoguery" and enters the realm of the "intolerable").

${ }^{659}$ HABER, supra note 639, at 234.

${ }^{660} \mathrm{Id}$. at 29; see HARKABI, supra note 659, at 111 (accusing MB of inciting "hatred" of Arabs).

${ }^{661}$ Cited in HABER, supra note_, at 255.

${ }^{662}$ HABER, supra note 639 , at 272.

${ }^{663}$ See id. at 245 (stating that as early as 1955 Begin believed "time was working in the Arabs' favor and that if Israel hesitated to launch a preemptive attack, she might find herself in a position that would preclude such deterrent action ever again.").

${ }^{664}$ See infra at note_.

${ }^{665}$ See Israeli and Iraqi Statements on Raid on Nuclear Plant ["Israeli and Iraqi Statements"], N.Y. TIMES, June 9, 1981, at A8 (indicating that Israel claimed to possess intelligence from "sources of unquestioned reliability" that the Osiraq reactor would be in production of nuclear weapons within three months).
} 
become operational. ${ }^{666} \mathrm{MB}$ personally defended the destruction of Osiraq as an act of ASD justified on the grounds that if Iraq, a state committed to the destruction of Israel, were permitted to acquire a nuclear reactor capable of producing weapons it would do so; that such weapons would certainly be used against Israel at the earliest possible juncture ${ }^{667}$ and that therefore Israel, and in particular its civilian population, was subject to an immediate and direct threat by the existence of an operational, or nearly operational, reactor. ${ }^{668} \mathrm{MB}$ claimed further that even if the reactor had not been fully operational, had Israel delayed until such time as it was fully operational before destroying it more Iraqi civilians would have been exposed to radiation leaking from the facility, a likelihood supporting the conclusion that the threat was already sufficiently imminent for purposes of Israeli compliance with IHL. ${ }^{669}$ In other words, the fact that the threat emanated from the proliferation of nuclear weapons to an enemy state determined to use them against Israel dictated a relaxed interpretation of imminence consistent with the magnitude and seriousness of the particular threat profile as perceived by the intended target of that threat.

Arab states swiftly and publicly condemned the attack, ${ }^{670}$ and the Security Council, with U.S. and UK support, ${ }^{671}$ followed suit, unanimously "condemn[ing] the military attack by Israel in clear violation of the Charter of the United Nations and the norms of international conduct" and stating that Iraq was entitled to "appropriate redress for the destruction it has suffered."

\footnotetext{
${ }^{666}$ David K. Shipler, Israeli Jets Destroy Iraqi Atomic Reactor, N.Y. TIMES, June 9, 1981, at A1. Most analysts believe the Osiraq reactor was either operational or nearly so: for a discussion of the operational status of the Osiraq reactor, see Louis Rene Beres \& Yoash Tsiddon-Chatto, Reconsidering Israel's Destruction of Iraq's Osiraq Nuclear Reactor, 9 TEMPLE INT'L \& COMP. L.J. 437, 438 (1995) (contending the reactor was operational or very nearly so); George Russell, Attack-and Fallout; Israel Blasts Iraq's Reactor and Creates a Global Shock Wave, TIME, June 22, 1981, at 24 (same); but see Anthony D'Amato, Israel's Air Strike Against the Osiraq Reactor: A Retrospective, 10 TEMP. INT'L \& COMP. L.J. 259, 261 (1996) (noting that the reactor was not operational at the moment of the attack).

${ }^{667}$ See Attack-and Fallout, TIME, June 22, 1981, at 24, 30 (reporting MB claim that after an Iranian aircraft had attempted unsuccessfully to bomb Osiraq, Iraq had stated that "[t]he Iranian people should not fear the Iraqi nuclear reactor, which is not intended to be used against Iran, but against the Zionist enemy."). The Iraqi government had released numerous statements calling upon Arab states to develop nuclear weapons for the destruction of Israel. See, e.g., IRAQI NEWS AGENCY (Baghdad), Aug. 19, 1980 ("President Saddam Hussein has stressed that a decision better than boycotting the states that move their embassies to Arab Jerusalem is to destroy Tel Aviv with bombs . . . The president concluded his speech by stressing that when the time comes for Iraq to vent its anger on the Zionist entity, it will do so.").

${ }^{668}$ See Israeli and Iraqi Statements, supra note 666, at A8 ("We were therefore forced to defend ourselves against the construction of an atomic bomb in Iraq, which itself would not have hesitated to use it against Israel and its population centers." (official statement of Israel); see also id. ("[The reactor was] intended . . . for the production of bombs. The goal for these bombs was Israel. This was explicitly stated by the Iraqi ruler. After the Iranians slightly damaged the reactor, Saddam Hussein remarked that it was pointless for the Iranians to attack the reactor because it was being built against Israel alone."(referencing an earlier Iranian attempt to destroy the reactor).

${ }^{669}$ See David Shipler, Begin Defends Raid, Pledges to Thwart a New “Holocaust,” N.Y. TIMES, June 10, 1981, at A12 (“We faced a terrible dilemma. Should we now be passive, and then lose the last opportunity, without those horrible casualties amongst the Baghdad population, to destroy the hotbed of death?") (arguing that the threat posed by the reactor was already imminent due to the increased civilian casualties that were certain to occur had Israeli waited to strike); Statement of Permanent Representative of Israel to the United Nations, U.N. SCOR, $36^{\text {th }}$ Sess., $2280^{\text {th }}$ mtg. at 57-60, U.N. Doc. S/PV.2280 (1981) (arguing that had Israel failed to strike immediately the Iraqi civilian casualties would have been unacceptably high and that as a consequence the threat was imminent as a matter of law); Excerpts from Security Council Provisional Verbatim Record of June 15,1981 ) ("[I]n removing this terrible nuclear threat to its existence, Israel was only exercising its legitimate right of self-defence within the meaning of this term in international law and as preserved also under the United Nations Charter."). In other words, further delay would have rendered an otherwise discriminate and proportional response an indiscriminate, disproportional, and therefore unlawful, use of force. See Schmitt, supra note 454, at 532-33 (describing the Israeli strike on Osiraq as a "surgical[] exterminat[ion] of the threat due to its limited scope and duration and the absence of civilian casualties).

${ }^{670}$ See Arabs Assail Raid as "Peak of International Terrism," N.Y. TIMES, June 9, 1981, at A1.

${ }^{671}$ See Roger K. Smith, The Legality of Coercive Arms Control, YALE J. INT'L L. 455, 485-87(1994) (“Armed attack in such circumstances . . . represents a grave breach of international law.") (remarks of British Prime Minister Margaret Thatcher); Judith Miller, U.S. Officials Say Iraq Had Ability to Make Nuclear Weapon in 1981, N.Y. TIMES, June 9, 1981, at A9 (reporting U.S. condemnation and suspension of arms shipments to Israel in response).

${ }^{672}$ U.N. S.C.Res. 487, U.N. SCOR, 36th Sess., 2288th mtg. at 58, U.N.Doc. S/PV.2288 (1981). The General Assembly joined in condemning the strike. G.A. Res. 27, 36 U.N. GAOR Supp. (No. 51) at 17, U.N. Doc. A/Res./ 36/27 (1981). 
could not prove that Iraq possessed nuclear weapons it intended to use in the very near future against Israel and that therefore the Iraqi threat was not so imminent that it left "no moment for deliberation" and created an immediate and overwhelming necessity to attack the reactor-a determination subsequently reinforced by evidence that Israel had initiated preparations and planning for the destruction of the Osiraq reactor at least as early as March $1981^{673}$ — vitiated the Israeli claim of lawfulness ${ }^{674}$ and suggested that the strike was a premeditated act in violation of Article 2(4). ${ }^{675}$ Although the Security Council imposed no sanctions, it rejected the Israeli claim to ASD because the threat, viewed in light of the traditional rule rather than in terms of the relaxed standard propounded by Israel, was deemed simply too prospective to justify the use of force.

In the main, the contemporaneous judgment of the legal academy affirmed the Security Council assessment that the Israeli attack could not be justified under the international law of self-defense on the grounds that Israel had neither satisfied the imminence requirement ${ }^{676}$ nor exhausted peaceful means of dispute resolution prior to engaging in self-help. ${ }^{677}$ At least one scholar drew the still-broader conclusion that even if ASD had survived the entry into force of the Charter it could not be exercised except with the prior approval of "some community of states." ${ }^{678}$ In other words, the Israeli air strike in 1981 stood for the proposition that the unilateral resort to force, however otherwise justified, was now incompatible with the framework of the Charter. However, with the benefit of two decades' hindsight some now question whether, in light of the revelation of new information regarding the extent of the Iraqi nuclear weapons program developed during the period from the Gulf War to the present, the Israeli claim that the threat posed by Iraq was imminent might have justified the attack on Osiraq as an act of ASD despite the absence of an "armed attack."

\footnotetext{
${ }^{673}$ See Smith, supra note 672, at 487 (noting MB conceded that Israeli preparations for the attack had commenced in March 1981 and noting further that Israel began developing intelligence about the reactor as a potential target as early as 1979).

${ }^{674}$ See, e.g., U.N. SCOR, 36 th Sess., 2282 mtg, at 106; U.N. Doc. S/PV/2282 (1981) ("It has been argued that the Israeli attack was an act of self-defence. But it was not a response to an armed attack on Israel by Iraq. There was no instant or overwhelming necessity for self-defence. Nor can it be justified as a forcible measure of self-protection. The Israeli intervention amounted to a use of force which cannot find a place in international law or in the Charter and which violated the sovereignty of Iraq.") (statement of Sir Anthony Parsons, UN Permanent Representative of United Kingdom).

${ }^{675}$ See, e.g., U.N. SCOR, 36th Sess., 2283d mtg. at 145, U.N. Doc. S/PV.2283 (1981) (evaluating Osiraq strike as having failed to satisfy the Caroline standard) (statement of Permanent Representative of Sierra Leone). For many states, however, the unlawfulness of the Israeli strike rested solely on the lack of an imminent threat-had it been clear that Iraq would produce nuclear weapons that would be imminently used against Israel, the Israeli strike might well have avoided condemnation. See Condron, supra note 562, at 137-39 (analyzing Council debates and reaching this conclusion).

${ }^{676}$ See D'Amato, supra note 667, at 260 (evaluating scholarly reaction to the Israeli attack on Osiraq).

${ }^{677}$ Smith, supra note 672, at 486-87; Sapiro, supra note 457, at 601.

${ }^{678}$ See Smith, supra note 672, at 495-96 ("The condemnation of Israel in 1981 . . suggests that the invocation of support from some community of states is an essential prerequisite for the permissible exercise of coercive arms control[.]").

${ }^{679}$ See Graham, supra note 465, at 10 (suggesting that the Israel attack may well have been justified as ASD on the ground that subsequent UN weapons inspections revealed the extent of the Iraqi nuclear weapons program was far closer to the Israeli estimate than to the international consensus and that had Israel permitted the Osiraq reactor to become operational the likelihood that Iraq would have developed weapons that could have destroyed Israel in the 1980s was great); Harold Hongju Koh, On American Exceptionalism, STAN. L. REV. 1479, 1516 (2003) (conceding that Israel faced an imminent threat in 1981 due to Iraqi progress toward completing nuclear weapons technologies). Interestingly, although the U.S. joined in the Security Council condemnation of Israel, as early as 1981 the U.S. confirmed that an important element of the factual predicate upon which Israel relied in destroying the Iraqi reactor - that Iraq had or would soon have nuclear weapons—was accurate. See Judith Miller, U.S. Officials Say Iraq Had Ability to Make Nuclear Weapon in 1981, N.Y. TIMES, June 9, 1981, at A9 (reporting that U.S. intelligence officials "believed that Iraq had acquired enough enriched uranium and sensitive technology to make one nuclear weapon by the end of [1981].").
} 
was unquestionable that Israel was the target of nuclear weapons, ${ }^{, 680}$ and that the attack on Osiraq was not an unlawful act of aggression but rather a "heroic and indispensable act of law enforcement[.]"681 Had Israel failed to destroy Osiraq in 1981, when Iraq invaded Kuwait in 1990 it might well have been in possession of nuclear weapons, and it is not inconceivable that a nuclear-armed Iraq might have been able to retain the fruits of its illegal aggression and fulfill its objective of becoming a regional superpower. It is fair to suggest that at least some actors now regard the attack on Osiraq as a lawful and legitimate act that prevented the further destabilization of the Middle East. It would seem undeniable that MB would not now decide the question of ASD any differently.

e. President Ronald W. Reagan and Libya (1986)

a. independent variables: personality constructs

i. militarism

President Ronald W. Reagan ["RWR"] believed the U.S. had a moral obligation not only to marshal its military force to fight evil in the world but to support friends and allies in this quest, ${ }^{682}$ and in support of this mission he presided over the largest peacetime increase in military spending in history. RWR had an abiding belief in the inherent goodness, even superiority, of the U.S., and was adamant in his refusal to allow any supranational form of government to reduce U.S. sovereignty. ${ }^{683}$ Still, RWR so disliked confrontation that he would retain aides long after he desired to terminate them and compromise with his political opponents whenever possible. ${ }^{64}$ However, RWR abhorred undisciplined or nonconformist behavior, ${ }^{685}$ was habitually early, ${ }^{686}$ and considered authorizing the CIA to conduct domestic surveillance of U.S. citizens suspected of disloyalty. ${ }^{687}$ These elements of personality suggest a streak of authoritarianism. Furthermore, despite his own lack of military service, RWR was fascinated with war and all that it entails, ${ }^{688}$ and he was "fierce[ly] patriot[ic]."

That RWR became President is perhaps surprising, as he was a relatively uncompetitive person who achieved success less by dint of aptitude and hard work than through good fortune and charm. ${ }^{690}$ His success may be attributable in part to his ambitious approach to life: RWR believed very sincerely that anything was possible, and he set lofty goals in his presidency, including victory in the Cold War and the dismantling of the regulatory state. Although he was the consummate "black and white thinker" inasmuch as for him every problem had a simple solution and all life was a struggle of good against evil in which all morality is on the side of the U.S. and liberalism is merely a stage on the road to

\footnotetext{
${ }^{680}$ Magenis, supra note 451, at 430; see also Beres \& Chatto, supra note 667, at 440 (“'[L]ooking back a decade and a half later it is well-known that Hussein's plans to build a French-supplied reactor . . . were designed to produce militarily significant amounts of weapons[.]").

${ }^{681} I d$. at 440.

${ }^{682}$ Glad, supra note 300, at 46; R.A. DAVIDSON, REAGAN V. QADDAFI: RESPONSE TO INTERNATIONAL TERRORISM

34 (2002) ("[T]he image that was foremost in everything [RWR] did was the projection of American strength.").

${ }^{683}$ GARY WILLS, REAGAN'S AMERICA: INNOCENTS AT HOME 247-48 (1987).

${ }^{684}$ See DONALD T. REGAN, FOR THE RECORD: FROM WALL STREET TO WASHINGTON 98 (1988).

${ }^{685}$ WILLS, supra note 684, at 34.

${ }^{686}$ REGAN, supra note 685, at 275.

${ }^{687}$ RONNIE DUGGER, ON REAGAN: THE MAN AND HIS PRESIDENCY 247 (1983).

${ }^{688}$ WILLS, supra note 684 , at 169.

${ }^{689}$ DAVIDSON, supra note 683, at 34.

${ }^{690}$ BARBER, supra note 304 , at 465.
} 
communism, ${ }^{691}$ RWR was a secure, confident, tremendously extroverted, ${ }^{692}$ and gregarious person who placed great value on friendships and the goodwill of others. ${ }^{63}$ He had enormously high emotional intelligence and good self-esteem. ${ }^{694}$ In sum, RWR scores high on seven of thirteen subconstructs of militarism—nationalism, FAP, patriotism, authoritarianism, militarism, dogmatism, and ambitiousnessand thus is scored a militarist.

ii. anomism

RWR was morally inflexible and absolutely rejected lying, cheating, stealing, homosexuality, and premarital sex on religious and ethical grounds. ${ }^{695}$ He was very much a traditionalist in terms of moral values. ${ }^{696}$ Although RWR lacked formal legal training, respect for law and legal authority were part and parcel of his abiding moral commitment to social conformity. ${ }^{697}$ Accordingly, RWR scores high on only one subconstruct of anomism-moralism—and thus is scored a non-anomist.

iii. hostility

RWR was so trusting of others that it "never occurred to him that anyone would give him incorrect information. ${ }^{\prime 698}$ His powerful and abiding sense of right and wrong, together with his generally positive view of humanity, his remarkable empathy, and his facility in interpersonal relationships, precluded narcissism, cynicism, misanthropy, and Machiavellianism. ${ }^{69}$ However, RWR, as exemplified by his adamant opposition to the Voting Rights Act, most civil rights legislation, and the teaching of students in languages other than English, created the impression that RWR was at the very least racially insensitive; in the words of columnist William Raspberry, "[t]he impression . . is that Reagan is not a racist...but that he simply does not give much of a damn one way or another. In practical effect it amounts to the same thing." ${ }^{700}$ Moreover, his image of the Soviet Union as the "Evil Empire"701 suggests that he perceived, whether accurately or not, that a powerful external actor maintained a highly negative image of and intention toward the free world. ${ }^{702}$

Still, RWR was committed to an international approach to the containment of Communism, and thus cannot be scored as an anti-internationalist. Nevertheless, despite his commitment to the defense of U.S. allies, there is inadequate information to conclude that RWR was an altruist rather than simply committed to alliances on instrumental grounds. In sum, RWR scores high on three of ten subconstructs of hostility and is thus a non-hostile decisionmaker.

iv. adventurism

\footnotetext{
${ }^{691}$ Glad, supra note 300 , at 51.

${ }^{692}$ VALENTY \& FELDMAN, supra note 226, at 122.

${ }^{693}$ MICHAEL BESCHLOSS \& STROBE TALBOTT, AT THE HIGHEST LEVELS 43 (1993).

${ }^{694}$ GREENSTEIN, supra note 227, at 157.

${ }^{695}$ DUGGER, supra note 688, at 261-64.

${ }^{696}$ GREENSTEIN, supra note 227, at 147.

${ }^{697}$ The presumption that RWR was unaware of and would not have approved any illegality during the Iran-Contra Affair is indulged to reach this conclusion.

${ }^{698}$ REGAN, supra note 685 , at 249.

${ }^{699}$ See VALENTY \& FELDMAN, supra note 226, at 122-24 (describing RWR as "radiating magnetism," very empathetic, and very uncritical and friendly with others).

${ }^{700}$ DUGGER, supra note 688, at 218 (quoting columnist William Raspberry).

${ }^{701}$ See President Ronald Reagan, Speech to the House of Commons, London, England, Jun. 8, 1982, available at http://www.fordham.edu/halsall/mod/1982reagan1.html.

${ }^{702}$ See Glad, supra note 375, at 45 ("Their statement about morality is that nothing is immoral if it furthers their cause, which means they can resort to lying or stealing or cheating, or even murder[.].") (quoting RWR regarding Soviet leaders).
} 
Although RWR established a bold agenda, he did not believe it necessary to take great risks as he reposited great faith in good fortune and regarded his endeavors as ordained to succeed by a higher power. ${ }^{703}$ RWR harbored extreme optimism and believed that "technology ha[d] a solution for everything." ${ }^{704}$ He delegated responsibility for major policy initiatives to subordinates and acted deliberately on the basis of their recommendations, ${ }^{705}$ and although stress accompanied his responsibilities, RWR was so confident in success that it is unlikely he experienced its effects to the degree others in his position would have. ${ }^{706}$ In sum, RWR scores high on three of seven subconstructs of adventurism - tolerance of risk, optimism, and male sex — and thus is scored a non-adventurist.

V. summary of IVs: RWR

RWR is a militarist who is neither anomistic, hostile, nor adventurist.

ii. DVs: ASD and Libya

On April 5, 1986, one day after U.S. intelligence intercepted a cable indicating Libyan terrorists would attack a target in Berlin the next day, a bomb detonated in a West Berlin nightclub known to be frequented by U.S. military personnel, killing two U.S. nationals and wounding 78 others. ${ }^{707}$ Nine days later, on April 14, U.S. FB-111 fighter-bombers departed from bases in England and attacked five military and regime targets in Libya. ${ }^{708}$ In his address to the nation, RWR indicated that the U.S. possessed "clear evidence that Libya is planning future attacks" and stated that the "preemptive action" was intended to "preempt and discourage Libyan attacks on innocent civilians in the future." Although in subsequent statements administration officials made reference to other claims to legal justification for the attack, including as a reprisal for the terrorist bombing of April $5^{\text {th }}$ and as an exercise of self-defense against ongoing attacks on U.S. nationals and embassies abroad, ${ }^{710}$ the official legal justification posited that Libya was actively planning future attacks against the U.S., ${ }^{711}$ that no diplomatic resolution was possible, and that the U.S. action constituted an exercise of the inherent right of ASD to preempt these future attacks consistent with Article 51 of the Charter. ${ }^{712}$

Although the UK, France, Australia, and Denmark joined the U.S. in preventing Security Council condemnation of the U.S. attack on Libya, ${ }^{713}$ many states judged the response to have been an unlawful reprisal, ${ }^{714}$ as did the General Assembly. ${ }^{715}$ Furthermore, a great many states and commentators found the

\footnotetext{
${ }^{703}$ REGAN, supra note 685 , at 250.

${ }^{704}$ WILLS, supra note 684 at $357-58$.

${ }^{705}$ GREENSTEIN, supra note 227, at 150 (describing RWR's management style as "hands-off" and as committed to and supportive of the positions presented by his aides).

${ }_{706}$ See REGAN, supra note 685, at _ (discussing RWR's approach to delegation of policy planning and management).

${ }^{707}$ See N.Y. TIMES, Apr. 6, 1986, at A1

${ }^{708}$ See Gwertzman, Plots on Global Scale Charged, N.Y. TIMES, Apr. 15, 1986, at A1.

${ }^{709}$ Address to the Nation, President Ronald W. Reagan, Apr. 14, 1986, reprinted in Reagan: "We Have Done What We Had to Do," WASH. POST, Apr. 15, 1986, at A23.

${ }^{710}$ See, e.g., U.S. Defends Raid Before U.N. Body, N.Y. TIMES, Apr. 16, 1986, at A17; statements of Ambassadors Okun and Walters before the U.N. Security Council, April 14-15, 1986, reprinted in 80 AM. J. INT'L L. 632-633 (1986).

${ }^{711}$ See Sofaer, supra note 448, at 921 (stating that the U.S. attacked Libya to prevent "some 30 possible impending Libyan attacks on U.S. facilities and personnel throughout the world.").

${ }^{712}$ See President's Report to the Speaker of the House of Representatives, Consistent with the War Powers Resolution, Relative to U.S. Air and Naval Forces Conducting Bombing Strikes on Terrorist Facilities and Military Installations in Libya, on April 14, 1986, 22 WEEKLY COMP. PRES. DOC. 499 (Apr. 16, 1986) (contending that the attack, justified under Article 51 as an act of ASD, was narrowly tailored to preempt future Libyan attacks on U.S. interests currently underway).

${ }^{713} 41$ U.N.SCOR, $2679^{\text {th }}$ mtg., UN Doc. S/PV 2678 (17 Apr. 1986).

${ }^{714}$ McCORMACK, supra note 451, at 229; DAVIDSON, supra note 683, at 94-96 (citing official criticisms of the strike).
} 
facts alleged in support of the argument that future attacks against which force had been directed were imminent to be insufficient to support the claim of self-defense, ${ }^{716}$ and still others concluded that the magnitude of the response was disproportionate to the alleged threat. ${ }^{717}$ Despite British support for the notion that the exercise of the inherent right to self-defense "plainly includes the right to destroy or weaken the capacity of one's assailant, reduce his resources, and weaken his will so as to discourage and prevent future violence[,]" ${ }^{, 718}$ the general conclusion within the international community was that the U.S. attack on Libya was difficult to characterize as anything but a reprisal and that, as such, the question of ASD had not arisen.

In retrospect, the sustained diplomatic and economic pressure on Libya since the 1986 strike has contributed to the recent Libyan concession that it had in fact developed an extensive chemical weapons program and the commitment to surrender those weapons; ${ }^{719}$ it is fairly arguable that, without the credible threat of future military sanctions that the 1986 strike made possible, the Qadhaffi regime would not have been motivated to refrain from terrorism in the intervening decades and to normalize relations with the international community. It seems also clear that RWR would consider his judgment to engage in ASD to have been well-advised.

\section{f. President George H.W. Bush and Panama (1989)}

a. independent variables: personality constructs

i. militarism

At 17, the forty-first U.S. president, George H.W. Bush [“41”], volunteered for service as the youngest U.S. Navy pilot in World War II and distinguished himself in action against Japan in the South Pacific. Although he was no militarist and recognized that the human cost of war was great, he proved himself willing to employ U.S. military forces to accomplish objectives in Panama, Iraq, and Somalia, and his positive attitude toward force is further reflected in his judgment that gun control is "not the American way." ${ }^{720} 41$ insisted that the U.S. was the dominant world power and that he would "ferociously defend that role against all comers at home and abroad." "21 His withering attacks during the 1988 campaign, his fondness for practical jokes, ${ }^{722}$ and his tendency to be angered by criticism ${ }^{723}$ are indicators of aggression, ${ }^{724}$ even if he is generally described as opposed to "jugular politics." ${ }^{, 725}$ During his political career, 41 was fueled by a driving ambition and would "fight like a junkyard dog to get what he wanted. ${ }^{, 726}$ He thrived on competition and hated to lose, ${ }^{727}$ and his lifelong desire to emulate his father as

\footnotetext{
${ }^{715}$ See G.A. Res. 41/38, 41 U.N. GAOR Supp. (No. 23), at 34-35 (condemning the U.S. attack as an unlawful act).

${ }^{716}$ See Romano, supra note 465, at 1041 (surveying international commentary on the U.S. attack on Libya and concluding that "the international community, in significant part, repudiated [the U.S. strike]").

${ }^{717}$ See, e.g., Paust, supra note 448, at 730-31 (arguing that 1) the U.S. introduced insufficient factual support for its assertion that future armed attacks were imminent and that 2) even if such attacks were certain it was not clear that U.S. action against Libyan targets, rather than defensive measures to protect intended U.S. targets, was the more proportionate and direct measure).

${ }^{718}$ Statement of Representative of the United Kingdom, 41 U.N.SCOR (2679 ${ }^{\text {th }}$ mtg), UN Doc. S/PV. 2678 (17 Apr. 1986$)$.

${ }^{719}$ See BBC, Libya to Give Up WMD, Dec. 20, 2003, available at http://news.bbc.co.uk/1/hi/world/africa/3335965.stm.

${ }^{720}$ MICHAEL DUFFY \& DAN GOODGAME, MARCHING IN PLACE: THE STATUS QUO PRESIDENCY OF GEORGE BUSH 29 (1992).

${ }^{721}$ Id. at 66.

${ }^{722}$ Id. at 41.

${ }^{723}$ Winters et al., supra note 263, at 458 (noting 41's unusual sensitivity to criticism).

${ }^{724} \mathrm{Id}$. at 460 (identifying aggression in 41's personality).

${ }^{725}$ OFFERMAN-ZUCKERBERG, supra note 299, at 106.

${ }^{726}$ DUFFY \& GOODGAME, supra note 721 , at 133.
} 
well as his strong drive to fashion order, both personal and international, lead experts to identify heightened authoritarianism in his personality. ${ }^{728}$

Still, if he lacked the "vision thing",729 and could sometimes be intellectually lazy or lack direction and ambition, ${ }^{730} 41$ is considered a cognitively complex person ${ }^{731}$ who solicited the contrary views of his advisors $^{732}$ and could untangle thorny issues and easily assimilate new and varied information.

Furthermore, 41 is an extroverted "man of action",733 and a "social animal" for whom "there is simply no event that can't be improved by the addition of more people." relationships, ${ }^{735}$ and the emphasis and skill be demonstrated in regard to multilateralism and coalitionbuilding in his foreign policy, ${ }^{736}$ evidence the absence of isolationism and anti-internationalism respectively. However, despite his great emotional intelligence and stable temperament, 41, perhaps struggling to overcome others" perception of him as a coddled "wimp",737 and to live up to his father's high expectations, suffers from fragile self-esteem. ${ }^{738}$

In sum, 41 scores as high on eight of thirteen subconstructs of militarism—nationalism, FAP, patriotism, aggression, military experience, competitiveness, ambitiousness, and low self-esteem—and thus is scored a militarist.

\section{ii. anomism}

Commentators offer little insight into the personality of 41 in terms of the subconstructs "disrespect for law" and "disrespect for legal authority." That his was an administration largely free of scandal and that he was appointed as Director of the CIA in order to supervise major reforms designed to render that agency more legalized and transparent suggest he is perceived as one who is neither disrespectful of law nor legal authority. Moreover, 41 placed much emphasis upon "family values" in his domestic policy agenda and implemented moral criteria to assess the acceptability of policy options. ${ }^{739}$ Although 41 had no formal legal training, he scores high on only two of five subconstructs-ignorance of law and ignorance of IHL-and thus is scored a non-anomist.

iii. hostility

Although he is a friendly and extroverted person, 41 believes we live in a dangerous world in which many harbor harmful intentions toward the U.S. ${ }^{740}$ Even in the waning years of the Cold War, 41 considered the Soviet Union a threat, and 41 regards political change, even when for the better, with

${ }^{727}$ OFFERMAN-ZUCKERBERG, supra note 299 , at 105.

${ }^{728}$ See, e.g., BARBER, supra note 304, at 462.

${ }^{729}$ GREENSTEIN, supra note 227, at 164.

${ }^{730}$ Most scholars regard 41 as ambitious, yet not overly so. See, e.g., OFFERMAN-ZUCKERBERG, supra note 299 , at 100.

${ }^{731}$ Winter et al., supra note 263, at 458 (scoring 41 high on cognitive complexity; GREENSTEIN, supra note 227, at 170 (scoring 41 "moderate" in cognitive complexity); but see OFFERMAN-ZUCKERBERG, supra note 299, at 109 (describing 41 as pragmatic but "stubborn").

${ }_{732}^{73}$ Winter et al., supra note 263, at 461.

${ }^{733}$ DUFFY \& GOODGAME, supra note 721, at 148; Winter et al., supra note 263, at 458 (describing 41 as extroverted).

${ }^{734}$ DUFFY \& GOODGAME, supra note 721 , at 55.

${ }^{735}$ See OFFERMAN-ZUCKERBERG, supra note 299, at 108 (indicating that 41 "cherishes and cultures" his friendships); id. at 105 (noting that of, all his government service positions, 41 liked his posts at the UN and as Ambassador to China because they afforded opportunities to meet people).

${ }^{736}$ See GREENSTEIN, supra note 227, at 170 (referencing 41's skill in assembling the coalition in Desert Storm in 1990).

${ }^{737}$ Winter et al., supra note 263, at 460.

${ }^{738}$ GREENSTEIN, supra note 227, at 171.

${ }^{739}$ BARBER, supra note 304, at 461.

${ }^{740}$ Winter et al., supra note 263, at 460. 
suspicion and a healthy dose of cynicism. ${ }^{741}$ Still, he is a self-effacing "team player" who is "born to please ${ }^{, 742}$ others, rather than a narcissist or a misanthrope, and while he is a pragmatic and flexible leader his moral foundation, his patrician sense of duty, and his great loyalty to subordinates ${ }^{743}$ suppress any tendency toward Machiavellianism. His support for the Civil Rights Act of 1990, his support for the marriage of his son Jeb to a Mexican-American woman, and his nomination of Colin Powell as Chairman of the Joint Chiefs of Staff suggest that it is very unlikely 41 is a racist or an ethnocentric. Finally, his eagerness to engage other states in the process of peace enforcement in Iraq, and afterward in the negotiation toward a more comprehensive Middle East peace agreement, support the assertion that 41 was no anti internationalist. Thus, 41 scores high on only three of seven subconstructs of hostility-distrust, cynicism, and hostility—and is scored a non-hostile decisionmaker.

iv. adventurism

41 is a patient person who is willing to take measured risks if the expected payoff is great enough but is generally cautious. ${ }^{744}$ His overriding concern was to "first, do no harm" and "not to make things worse," and he revealed that he would "rather be called cautious than I would be called reckless."745 Still, as President 41 believed that there was a relationship between the selection of policies and outcomes, and he had the "quiet confidence that there [wa]s nobody better qualified to make . . . the kind of high stakes, history-making decisions" ${ }^{, 74}$ that faced him. If he was sometimes hasty ${ }^{747}$ or failed to consider alternatives to, and consequences of, his decisions, ${ }^{78}$ he was also sometimes indecisive; above all, once 41 made a decision he was confident and did not suffer from anxiety. ${ }^{749}$ In sum, 41 scores high on three of seven subconstructs of adventurism — internal locus of control, optimism, and male sex-and thus is scored nonadventuristic.

v. summary of IVs: 41

41 is a militarist who is neither anomistic, hostile, or adventuristic.

b. DVs: ASD and Panama

By 1988, the regime of Panamanian dictator Manuel Noriega, who had been indicted in February in the U.S. for narcotrafficking, was engaged in a systematic pattern of violence and intimidation against U.S. military and civilian personnel in Panama. ${ }^{750} 41$, who during the presidential campaign had adamantly refused to accept any other solution to mounting tensions other than for Noriega to leave power and stand trial, concluded in the summer of 1989 that military action would be necessary to install

\footnotetext{
${ }^{741}$ GREENSTEIN, supra note 227, at 164-65.

${ }^{742}$ OFFERMAN-ZUCKERBERG, supra note 299, at 114.

${ }^{743} I d$. at $107,116$.

${ }^{744}$ Id. at 106 (citing examples from 41's career and business decisionmaking).

${ }^{745}$ DUFFY \& GOODGAME, supra note 721, at 65, 191; RYAN J. BARILLEAUX \& MARK J. ROZELL, POWER AND PRUDENCE: THE PRESIDENCY OF GEORGE H.W. BUSH (2004) (characterizing 41 as an "incrementalist" without a policy agenda for which he was willing to take risks).

${ }^{746} I d$. at $41,135$.

${ }_{747}^{74}$ See Winter et al., supra note 263 , at 460 (contrasting 41 's impulsivity with his indecisiveness).

${ }^{748}$ See GREENSTEIN, supra note 227, at 170 (suggesting 41 may have inadequately explored the possibility of ejecting Iraq from Kuwait through economic sanctions and may have given inadequate consideration to the costs of leaving Saddam Hussein in power in 1991).

${ }_{749}$ Winter et al., supra note 263 , at 458.

${ }^{750}$ See KEVIN BUCKELY, PANAMA 161 (1991) (chronicling "hundreds" of incidents of anti-Americanism, including assaults, rapes, beatings, and detentions, committed by Noriega's Panamanian Defense Forces during summer 1988).
} 
the democratically-elected Guillermo Endara whom Noriega had deposed. ${ }^{751}$ By September 1989, U.S. officials deemed an invasion of Panama a "very high probability," and in October Noriega ordered the Panamanian Defense Forces to shoot down any and all U.S. aircraft in Panamanian airspace. An abortive October coup caused embarrassment to 41 , as Congress, including members of his own party, criticized his failure to support the rebels and resurrected the question of the "wimp factor."752 By late October, the commander of the U.S. Southern Command described U.S.-Panamanian relations as a "state of war.,"753

On 15 December 1989, Noriega declared that "[t]he republic of Panama [was] in a state of war [with the U.S.]" ${ }^{1754}$ and later that evening PDF soldiers shot and killed a U.S. officer at a roadblock and kidnapped and tortured a second officer and his wife. ${ }^{755}$ With that, 41 reached the decision to intervene, claiming that U.S. citizens in Panama were in "grave danger" and that "every other avenue was closed[.]" 756 OPERATION JUST CAUSE ["OJC"], launched for the stated objectives of capturing Noriega, preserving the safety of U.S. citizens, and protecting the Panama Canal treaties, ${ }^{757}$ and justified on the ground that Noriega had declared war upon the U.S., ${ }^{758}$ was initiated on 20 December, and within two weeks Noriega was in custody and Endara was empowered in Panama. In the immediate aftermath, 41 formally justified OJC as an exercise of ASD consistent with Article 51 of the Charter. ${ }^{759}$

In the main, international response was favorable. In May of 1989, the OAS had demanded Noriega's resignation and removal from power, ${ }^{760}$ and international criticism upon the capture of Noriega was largely absent. A Soviet-sponsored resolution that would have labeled OJC "a flagrant violation of international law" was swiftly opposed and defeated by Great Britain, France, and Canada in the Security Council, ${ }^{761}$ and the General Assembly abstained from the question. Scholars were more critical of the assertion of ASD in conjunction with OJC; although some a number lauded 41's decision to use force to protect U.S. nationals, ${ }^{762}$ others regarded any threat to U.S. nationals as the consequence of U.S. pressure

\footnotetext{
${ }^{751}$ See id. at 163, 188-89 (describing transformation of 41's Panama policy in light of Noriega's refusal to permit Endara to assume office and escalating anti-American violence); $i d$. at 192 (noting that 41 described the violent interference with the May 1989 election of Endara as a violation of Panamanian "self-determination").

${ }^{752} I d$. at 213, 219, 222 (describing domestic reaction to U.S. refusal to support the coup and role of coup in relation to perception of 41 as weak-willed). The "wimp factor" is a reference to the widespread perception of 41, prior to the invasion of Panama and to a lesser extent before Desert Storm, as an effete Northeastern scion of privilege who was unable to, and had never had to, "fight dirty" and hard to succeed. See Margaret Warner, Fighting the Wimp Factor, NEWSWEEK (1987).

${ }^{753} I d$. at 222 (quoting General Thurman).

${ }^{754}$ See Katherine Rahman, The Panamanian Revolution: Diplomacy, War and Self-Determination in Panama (I \& II), SelfDetermination and Intervention in Panama (I), AM. SOC. INT'L L. PROC. 182, 183 (1991).

${ }_{755}^{75}$ BUCKLEY, supra note 751, at 226-27.

${ }^{756}$ See Statement by President George Bush (Dec. 20, 1989) (Office of the Press Secretary, the White House).

${ }^{757}$ See Douglas Kash, The Capture of Manuel Antonio Noriega: A Legal Analysis, 4 TOURO J. TRANSNAT'L L. 251,252 (1993) (quoting 41's statement of reasons for OPERATION JUST CAUSE).

${ }^{758}$ See BUCKLEY, supra note 751, at 242 (referencing 41 statement on 21 December that the justification for OPERATION JUST CAUSE was the declaration of war and the threat this posed to U.S. nationals and interests).

${ }_{759}$ See N.Y. Times, Dec. 21, 1989, at A19 (quoting Secretary of State James Baker as stating that the U.S. was "entitled . . to take measures necessary to defend our military personnel, our . . nationals and U.S. installations."); see also Letter to the Speaker of the House of Representatives and the President Pro Tempore of the Senate on the United States Military Action in Panama (Dec. 21, 1989), 2 PUB. PAPERS OF GEORGE BUSH 1734 (1989) ("The deployment of U.S. Forces is an exercise of the right of self-defense recognized in Article 51 of the [UN] Charter and was necessary to protect American lives in imminent danger."). The U.S. did not indicate whether it took the position that an armed attack had already occurred. Id.

${ }^{760}$ See BUCKELY, supra note 751, at 186-88.

${ }^{761}$ See UN Doc. S/21048 (Dec. 22, 1989); UN Doc. S/PV. 2902 (Dec. 23, 1989).

${ }^{762}$ See, e.g., Agora: U.S. Forces in Panama: Defenders, Aggressors or Human Rights Activists? 84 AM. J. INT'L L. 494,519 (stating that the OJC was a lawful intervention that did not violate Article 2(4) and served a valid humanitarian purpose) (opinion of Professor Anthony D'Amato); Rahman, supra note 755, at 184 ("These hostile acts of the Noriega regime . . . constituted a form of aggression against the United States serious enough to justify appropriate defensive action.") (statement of Legal Adviser to the Department of State Abraham Sofaer); id. at 189-90 (stating that given the pattern of aggression against U.S. nationals by
} 
upon the Noriega government and thus rejected as unnecessary the use of force to protect U.S. nationals endangered by, in effect, the actions of the U.S.; ${ }^{763}$ still others suggested that the threat lacked sufficient imminence to justify $\mathrm{ASD}^{764}$ or criticized OJC as a disproportionate employment of force; ${ }^{765}$ the most absolutist regarded OJC as an ipso facto violation of Article 2(4). ${ }^{766}$ Still, the ouster of Noriega, and his subsequent conviction and imprisonment for narcotrafficking, ${ }^{767}$ raised little criticism outside the confines of the legal academy. ${ }^{768}$

In retrospect, most would likely conclude that OJC contributed to the stability of Central America and to the reduction in international narcotrafficking, ${ }^{769}$ and the successful prosecution of Noriega, coupled with the preservation of free transit through the Panama Canal, suggests strongly that 41 would not be dissuaded from deciding to launch OJC again under identical circumstances.

g. President William J. Clinton and Afghanistan/Sudan (1998)

a. IVs: personality constructs

i. militarism

President William Jefferson Clinton ["WJC"] is the incarnation of the modern internationalist who envisions the U.S. as one state among many. Although he has a respect for and appreciation of the importance of power in international relations, ${ }^{770} \mathrm{WJC}$ is not a patriot, and when called to military service was skillful in avoiding the discharge of his duty. He is an aggressive person subject to fits of anger ${ }^{771}$ who, although capable of compromise, ${ }^{772}$ tends to "lash out against institutions or groups who opposes his policies," and when others criticize him he "disowns them and turns against them angrily." he is a dogmatist convinced he knows what is right and best for others and that those who do not embrace his views are misguided at best and driven by "base motives" at worst, ${ }^{774} \mathrm{WJC}$ is far too much a man of expedience and moral relativism to be labeled an authoritarian. Furthermore, his avoidance of military service disqualifies him as a militarist. That said, WJC is intensely competitive and ambitious (even to a

the Noriega regime, "the U.S. action in Panama was not inconsistent with the fundamental purposes and principles of the UN Charter and the rule of law.") (statement of Professor John Norton Moore).

${ }^{763}$ See Rahman, supra note 755, at 188 (restating the opinion of Professor Tom Farer).

${ }^{764}$ Agora, supra note 763, at 497 (arguing that "[t]he state of tension existing in Panama did not present an imminent danger to U.S. citizens.") (statement of Professor Ved Nanda).

${ }^{765}$ Rahman, supra note 755, at 193 (reporting statement of Professor Jordan Paust); Agora, supra note 763, at 497 (same) (opinion of Professor Ved Nanda).

${ }^{766}$ See, e.g., Rahman, supra note 755, at 189 (describing U.S. justifications as a "bad faith interpretation, incompatible with the primary object and purpose of the UN Charter[.]") (statement of Professor Maria Frankowska).

${ }_{767}^{767}$ See U.S. v. Noriega, 746 F. Supp. 1506 (S.D. Fla. 1990) (convicting Noriega on numerous counts of drug trafficking).

${ }^{768}$ Most of the criticism of OJC has centered not upon the lawfulness of the intervention but upon the claim that the U.S. violated the principles of proportionality and distinction and as a consequence produced unnecessary civilian casualties. See, e.g., RAMSEY CLARK (note); but see John Embry Parkerson, United States Compliance with Humanitarian Law Respecting Civilians During Operation Just Cause, 133 MIL. L. REV. 31 (1991) (rebutting such claims).

${ }^{769}$ See, e.g., Yoo, supra note 556, at 563 (reaching this conclusion).

${ }^{770}$ POST, supra note 232, at 319.

${ }^{771}$ See GREENSTEIN, supra note 227, at 186.

${ }^{772}$ POST, supra note 232, at 315 (stating that under some circumstances WJC views politics as requiring compromise and consensus).

${ }^{773} I d$. at 291.

${ }^{774} \mathrm{Id}$. at 286. WJC is generally regarded as cognitively complex. See, e.g., GREENSTEIN, supra note 227, at 187 . However, some analysts believe that despite his great intellect WJC is neither cognitively and nor particularly adaptable to the environment and that his analysis is frequently underdeveloped. POST, supra note 232, at 322; see also GREENSTEIN, supra note 227, at 188 (stating that WJC is very intelligent but unable to reach a balanced net assessment of a problem and that he analyzes issues with the "speed of oil covering water, but sometimes does so at the same depth.").

Given the lack of consensus, and in light of his authoritarianism, WJC is scored for purposes of this study as dogmatic. 
fault), ${ }^{775}$ tremendously energetic and articulate, and extroverted. He is a charming person interested in fellowship ${ }^{776}$ and wins friends easily, although he does not always inspire their loyalty. ${ }^{777}$ WJC is a selfconfident person with high self-esteem. ${ }^{778}$ WJC thus scores as high on four of thirteen subconstructs of militarism-aggression, competitiveness, dogmatism, and ambitiousness—and is scored a non-militarist.

ii. anomism

Although he has a law degree from Yale University, WJC was disbarred by the Supreme Court of Arkansas for perjury in the civil suit brought against him for sexual harrassment by a former state employee. He is described as an "emotionally challenged" person with major "psychic shortcomings",779 and as a "skilled liar." ${ }^{, 70}$ WJC does not behave as if he has any coherent moral principles save for selfinterest, and cannot be relied upon to adhere to his commitments. ${ }^{781}$ In short, WJC scores high on all subconstructs of anomism save for ignorance of law and ignorance of IHL, and thus is scored an anomist. iii. hostility

Although he is a committed internationalist, ${ }^{782}$ WJC sees the political universe as hostile, ${ }^{783}$ and as President believed his opponents were "out to get" him and prevent him from accomplishing an "important, major, or unusual" mission that he was valiantly struggling to accomplish. ${ }^{784}$ In short, WJC is a narcissist who self-defines his modest achievements as "grandiose" accomplishments and who believes he is special and therefore entitled to dispensations from the rules that govern others. ${ }^{785} \mathrm{He}$ is incapable of admitting even the slightest errors. ${ }^{786}$ Still, WJC is neither cynical nor misanthropic: he has a much greater-than average capacity to empathize ${ }^{787}$ and actively enjoys his many affiliations. Nor is he an ethnocentrist: WJC, our "first black President," ${ }^{778}$ is famously comfortable with persons of other races and nationalities and made improving race relations a centerpiece of his domestic agenda. ${ }^{789}$ However, his mendacity, infinitely flexible moral code, and overweening concern with self-interest brand WJC a selfish Machiavellian. In sum, WJC scores as high on all but three of ten subconstructs of hostilitymisanthropy, ethnocentrism, and lack of empathy_and thus is scored as hostile.

iv. adventurism

\footnotetext{
${ }^{775}$ POST, supra note 232, at 288 (ambitious); GREENSTEIN, supra note 227, at 177 (suggesting that WJC advanced more policy initiatives than he could possibly manage); POST, supra note 232, at 297 (competitive).

${ }^{777}$ POST, supra note 232, at 279.

${ }^{777}$ GREENSTEIN, supra note 227, at 186 (noting that WJC is neither loyal nor inspiring of loyalty).

${ }^{778}$ POST, supra note 232, at 308.

${ }^{779}$ GREENSTEIN, supra note 227, at 188.

${ }^{780}$ Id. at 184; see also POST, supra note 232, at 286 (noting that WJC typically lies by omission or bends the truth to support a "self-idealized view of his behavior" that is at odds with the facts).

${ }^{781}$ See id. at 286 (suggesting that WJC's early life experiences with an abusive stepfather and a narcissistic mother taught him that "those on whom you should be able to count are often unreliable" and that he need not maintain "fidelity to his commitments to others[.]").

${ }^{782}$ See supra at p._.

${ }^{783}$ VALENTY \& FELDMAN, supra note 226, at 55-56.

${ }^{784}$ POST, supra note 232, at 286, 295.

${ }^{785}$ Id. at 296-99.

${ }^{786}$ See id. at 298 (noting WJC cannot admit even the slightest mistakes, including experimentation with drugs or minor personnel errors); id. at 292 (WJC "appears to believe the best of himself and either to avoid or discount evidence from his own behavior that indicates all is not as he believes it to be" and that "[a]ny attention called to a number of discrepancies between his real behavior and his view of it ... was met with denial, exculpatory explanations, mostly long but sometimes short answers that did not deal directly with the point, and, when all else failed, unconcealed frustration and anger.").

${ }^{787}$ GREENSTEIN, supra note 227, at 175.

${ }^{788}$ Toni Morrison, The New Yorker, Oct. 1998.
} 
WJC is a "breathtakingly reckless" ${ }^{\text {"790 }}$ and undisciplined person who was nearly forced from office for lying under oath in a civil deposition about his relationship with a White House intern. Although he is above-average in his belief that he is capable of asserting positive control over the world about him and discounts the role of chance, ${ }^{791}$ his impatience and impulsivity frustrate his designs. ${ }^{792}$ Nonetheless, WJC is an optimist ${ }^{793}$ who does not experience the degree of stress or anxiety that would be expected of an individual as impulsive as he, and even after setbacks he continues to perceive his prospects for attaining his objectives as extremely high. ${ }^{794}$ WJC thus scores as high on five of seven subconstructs of adventurism - tolerance of risk, internal locus of control, impulsivity, optimism, and male sex-and is scored an adventurist.

\section{v. summary of independent variables}

WJC is scored as a non-militarist who is anomistic, hostile, and adventuristic.

b. dependent variable: ASD and Afghanistan/Sudan

On August 20, 1998, twelve days after the al Qaeda terrorist group attacked and destroyed the U.S. embassies in Tanzania and Kenya and during the height of a Congressional inquiry into presidential misconduct that would eventually lead to his impeachment, WJC ordered cruise missiles launched at several al Qaeda terrorist training camps in Afghanistan and at the al Shifa factory in Sudan, alleging the latter was a production facility for chemical weapons intended for al Qaeda. ${ }^{795}$ Although various Administration officials hinted that the action had been undertaken in retaliation for the embassy bombings, ${ }^{796}$ the U.S. invoked ASD as the legal justification for its attacks on Afghanistan and Sudan, contending that the application of military force had been necessary to prevent specific imminent terrorist attacks about which it possessed clear and credible intelligence. ${ }^{797}$

Some restrictivist scholars argued that the U.S. failed to established that the threat posed by al Qaeda was sufficiently imminent as to be necessary for purposes of analysis under the Caroline standard, and that the action must consequently be examined not as an exercise of ASD but rather as an act of

\footnotetext{
${ }^{789}$ See E.O. No. 13,050, 3 C.F.R. 207, 207-08, 62 Fed. Reg. 32987 (1997) (directing President's Advisory Board on Race to "advise the President on matters involving ... racial reconciliation").

${ }^{790}$ GREENSTEIN, supra note 227, at 182; see also POST, supra note 232, at 295 (scoring WJC as moderately high on risk propensity relative to other former Presidents).

${ }^{791}$ See VALENTY \& FELDMAN, supra note 226, at 56 (comparing WJC to other Presidents); POST, supra note 232, at 319 (same).

${ }^{792}$ Id. at 308 .

${ }^{793}$ POST, supra note 232, at 309; VALENTY \& FELDMAN, supra note 226, at 55-56.

${ }^{794}$ POST, supra note 232, at 320.

${ }^{795}$ James Bennet, U.S. Cruise Missiles Strike Sudan and Afghan Targets Tied to Terrorist Network, N.Y. TIMES, Aug. 21, 1998, at A1.

${ }^{796}$ See, e.g., Bradley Graham, Bin Laden Was at Camp Just Before U.S. Attack, WASH. POST, Aug. 29, 1998, at A1 (quoting U.S. officials that plans for strikes were conceived as retaliatory measures to potential terrorist attacks before the embassy bombings); Secretary of State Madeleine Albright, Remarks during Appearance on This Week (Aug. 23, 1998) (available at 1998 WL 6392416 at 4) (stating that the embassy bombings "had a huge part" in prompting attacks on Afghanistan and Sudan). ${ }^{797}$ See Bennett, supra note 796 (reporting that the Clinton Administration justified the strikes on the grounds that al Qaida was responsible for these and other acts of terrorism and had declared its intention to conduct additional attacks and that "key terrorist leaders" were gathered at the headquarters, establishing the imminence of a continuing threat to U.S. nationals); "We Acted to Preempt Terrorist Acts", WASH POST., Aug. 21, 1998, at A19 (describing strikes as oriented toward "do[ing] something that would disrupt Osama bin Laden and his organization's ability to conduct additional terrorist activities[.]") (quoting Secretary of State Albright); id. (quoting National Security Adviser Sandy Berger to the effect the U.S. "had very specific information about very specific threats with respect to very specific targets[.]").
} 
reprisal for the embassy bombings. ${ }^{798}$ To some degree, criticisms of the U.S. ASD justification hinged on the sufficiency of the evidence offered in support of the claim: some commentators, otherwise supportive of the inherent right of states to engage in ASD, questioned its applicability given the absence of sufficient proof of imminence, ${ }^{799}$ while others, although generally hostile to ASD, evaluated the U.S. claim on its merits while nonetheless concluding that the "questionable nature of some of [the U.S.] factual assertions, and the circumstances surrounding the strikes, render the success of its legal justification very unique. ${ }^{, 800}$ Although the U.S. countered reports that the factory and the camp had been developed by U.S. intelligence and military officials as a potential targets many months before their destruction ${ }^{801}$ by releasing some of the intelligence upon which it had relied in reaching its decision to destroy the sites, ${ }^{802}$ restrictivists seized upon these reports and other indications that the factory may not have in fact been a chemical weapons production facility ${ }^{803}$ as proof that the strikes were indefensible as acts of ASD inasmuch as any threats that had existed for months without necessitating a U.S. attack were not suddenly invested with imminence by the destruction of the U.S. embassies.

Nevertheless, despite widespread and general dissatisfaction with the evidentiary support for the U.S. strikes, the Security Council took no formal action, ${ }^{804}$ nor did the attacks or the justification therefor confront substantial political opposition internationally. ${ }^{805}$ Although some commentators consider the muted international response a reflection of the distaste for al Qaeda and grudging tolerance of incomplete disclosure of intelligence sources and means in the particular case at issue, rather than an affirmation of a right to ASD, ${ }^{806}$ pragmatists suggest that the U.S. strikes on Sudan and Afghanistan demonstrate that the right of states to engage in ASD is, if not already a norm of customary international

\footnotetext{
${ }^{798}$ See Jordan J. Paust, Use of Armed Force Against Terrorists in Afghanistan, Iraq, and Beyond, 35 CORNELL INT'L L. J. 533, 536 (2002) (suggesting that, although the strikes may well have been directed towards future unspecified but anticipated al Qaida attacks., the threats posed by such potentialities was not sufficient to constitute imminence for purposes of evaluation as an act of ASD); Lacey, supra note_, at 296-97 (contending that on the evidence offered it is impossible for the U.S. to argue that the destruction of its embassies required an instant, overwhelming response against the targets selected and that it had "no choice of means, and no moment for deliberation.") (citing the Caroline standard).

${ }^{799}$ On the basis of evidence made available for review it was difficult for commentators to comprehend precisely how the destruction of the Sudanese factory was necessary to prevent imminent terrorist attacks, for if the attacks were in fact imminent it was unlikely terrorists would receive weapons produced by the factory in the near-term future and any imminent attacks would be conducted with weapons already in possession. See, e.g., Guy B. Roberts, The Counterproliferation Self-Help Paradigm: A Legal Regime for Enforcing the Norm Prohibiting the Proliferation of Weapons of Mass Destruction, 27 DENV. J. INT'L L. \& POL. 483, 535 (1999) (accepting ASD in principle but rejecting application to Sudan on the ground the U.S. had failed to "convincingly explain that acquisition [of chemical weapons] and use was imminent.").

${ }^{800}$ Romano, supra note 465, at 1041.

${ }^{801}$ See Vernon Loeb \& Bradley Graham, Sudan Plant Was Probed Months Before Attack, WASH. POST, Sept. 1, 1998, at A14 (factory); Bradley Graham, Bin Laden Was at Camp Just Before U.S. Attack, WASH. POST, Aug. 29, 1998, at A1 (camp).

${ }^{802}$ See Linkie, supra note_, at 569 (noting that the U.S. produced physical evidence that the al Shifa facility had been producing chemical precursors for VX nerve gas). For further discussion of the U.S. evidence, see Pentagon and C.I.A. Defend Sudan Missile Attack, N.Y. TIMES, Sept. 2, 1998, at A5.

${ }^{803}$ See David L. Marcus, Franck Criticizes Bombing of Plant in Sudan, BOSTON GLOBE, Sept. 25, 1998, at A9 (stating that newly-released evidence suggests the Sudanese factory was in fact either a pharmaceutical plant or an animal feed plant as claimed by Sudan).

${ }^{804}$ Yoo, supra note 556, at 573. In a letter to the President of the Security Council justifying the U.S. attacks, the U.S. claimed to have acted only after repeated warnings to Afghanistan and Sudan to "shut down terrorist activities and cease cooperation with the Bin Ladin Organization[.]” U.N. Daily Highlights, Aug. 21, 1998.

${ }^{805}$ See Douglas Jehl, U.S. Raids Provoke Fury in Muslim World, N.Y. TIMES, Aug. 22, 1998, at A6 (discussing reactions to 1998 strikes and reporting that most of the hostility was confined to Islamic states); Romano, supra note 465, at 1041 (noting that the justification of ASD was received "with scant objection from the international community.").

${ }^{806}$ See id. ("Perhaps the relatively passive international response is best explained by the wealth of intelligence information the United States had amassed linking Osama bin Laden's terrorist network to the embassy bombings and other past terrorist plots.”).
} 
law that predates and survives the Charter, emerging as lex ferenda ${ }^{807}$ Few states or commentators conclude that the attacks were either lawful or legitimate, and it is doubtful, given the insufficiency of the evidence and the lack of support for the action, that WJC would make the same decision again. After the spectacular disaster of September $11^{\text {th }}, 2001$, it is impossible to say that the attacks of 1998 contributed to world order by promoting a credible deterrent regime.

h. President George W. Bush [“43”] and Iraq (2003)

a. independent variables: personality constructs

i. militarism

President George W. Bush ["43"] is a nationalist and a patriot who has declared that his life's mission is to "wag[e] [a] struggle for freedom and security for the American people" against international terrorism. ${ }^{808}$ Power, and in particular military power, is the primary instrument of his foreign policy, and he enjoys wielding it to accomplish his objectives. ${ }^{809} 43$ is an aggressive personality who is concerned that a failure to meet force with force will communicate the lesson of a "not very tough [U.S.]" and that the enemies of the U.S. must feel threatened by U.S. power. ${ }^{810}$ While not an authoritarian or a militarist, 43 is an assertive and competitive personality ${ }^{811}$ who served as an Air National Guard fighter pilot.

43 tends toward low cognitive complexity, superficial thinking, and low introspection, ${ }^{812}$ although he "exhibits depth of comprehension," "visualize[s] alternatives and weigh[s] long term consequences," and "keeps himself thoroughly informed" on policy issues. ${ }^{813} \mathrm{He}$ is an engaging and gregrious extrovert who makes and keeps friends with ease and is inclusive in his social life. ${ }^{814}$ Although not particularly high in his need for achievement, ${ }^{815} 43$ has embraced the "ambitious reordering of the world" effect, make the world safe from terrorism. Although his self-confidence is only moderate, 43 has high self-esteem. ${ }^{817}$ In sum, 43 scores high on eight of thirteen subconstructs of militarism—nationalism, FAP, patriotism, aggression, military experience, competitiveness, dogmatism, and ambitiousness — and thus is scored a militarist.

ii. anomism

Although he cannot be described as an outlaw, 43 has a personal history of minor brushes with the law, including driving under the influence, and his disdainful statement in regard to the applicability of international law to the awarding of contracts for the reconstruction of Iraq- "International law?

\footnotetext{
${ }^{807}$ See, e.g., id. at 1040 (suggesting that the largely absent criticism of the U.S. strikes bespeaks "growing acceptance" of ASD). The most pragmatist scholars insist that because the threat posed by WMD-armed terrorists requires a transformed imminence standard the strikes were perfectly legitimate. See, e.g., Addicott, supra note 444, at 772.

${ }^{808}$ BOB WOODWARD, BUSH AT WAR 108 (quoting 43 in his address to the nation shortly after September 11 $1^{\text {th }}, 2001$ ).

${ }^{809}$ See VALENTY \& FELDMAN, supra note 226, at 41, 98-99, 101 (stating that 43 "enjoys the power to direct others and to evoke respect").

${ }^{810}$ WOODWARD, supra note 809 , at 38 .

${ }^{811}$ See VALENTY \& FELDMAN, supra note 226, at 98-99 (describing 43 as "authoritative without being authoritarian"); id. (noting that 43 "creates rules and expects subordinates to follow them, though within reasonable limits").

${ }^{812}$ See id. at 98-99 (describing 43 as "anti-introspective and unwilling to acknowledge disturbing emotions, denying personal difficulties or covering inner conflicts with self-distraction.”).

${ }^{813}$ Id. at $93-95,100$.

${ }^{814}$ See id. at 90, 98-99 (describing 43 as "[d]isarmingly affable and charming").

${ }^{815} \mathrm{Id}$. at 90 .

${ }^{816}$ WOODWARD, supra note 809, at 341.

${ }^{817}$ VALENTY \& FELDMAN, supra note 226, at 95-96.
} 
Nobody told me about that. I better call my lawyer." ${ }^{, 818}$ — belies a general lack of respect for law and legal authority. Still, 43 believes that the U.S. is engaged in a "monumental struggle between good and evil" against terrorism $^{819}$ and that U.S. foreign policy, particularly the liberation of the Afghani and Iraqi peoples, is a moral obligation predicated upon a "value system that cannot be compromised-God-given values. ${ }^{, 220} 43$ has no formal legal training. 43 scores high on all subconstructs of anomism save for amoralism and is thus scored an anomist.

iii. hostility

For the most part, 43 sees the world as more cooperative than conflictual, and he harbors relatively low distrust. ${ }^{821}$ Although he sees himself as a visionary who "seize[d] the opportunity to achieve ... world peace" through the defeat of terrorism, ${ }^{822}$ psychobiographers rate 43 moderately low on narcissism indices. ${ }^{823} \mathrm{He}$ is neither a cynic nor a misanthrope; rather, he is a "generally benevolent and approval-seeking" ${ }^{, 24}$ person who enjoys cooperative relationships and is possessed of great emotional intelligence. ${ }^{825}$ However, 43 believes that many domestic critics view him as "the toxic Texan" ${ }^{\text {" } 26}$ and that the U.S. is the target of a vast consortium of international terrorists, and he has proven "willing to scheme in calculated fashion to realize personal ambitions, ${ }^{, 827}$ suggesting elevation on the Machiavellianism subconstruct. Moreover, although 43 prefers multilateralism, his post-9/11 approach to foreign policy suggests a strong anti-internationalist bent that is difficult to reconcile with his more stable cooperative preference. There is little evidence to suggest elevation on the selfishness subconstruct, although it is possible to score 43 high without altering the global score on the hostility construct.

43 scores high on only three of ten subconstructs of hostility-hostility, Machiavellianism, selfishness, and anti-internationalism—and thus is scored a non-hostile decisionmaker.

iv. adventurism

43 is a cautious and risk-averse person who nevertheless believes that he has a duty and the capacity to lead the U.S. on a mission to make the world safe from terrorism, and he is highly impulsive. ${ }^{828}$ Nevertheless, 43 is an optimist whose faith insulates him from significant stress or anxiety. ${ }^{829}$ In sum, 43 scores as high on four of seven subconstructs of adventurism-internal locus of control, impulsivity, optimism, and male sex — and thus is scored as an adventurist.

v. summary of IVs: 43

43 is a militarist who is anomistic and adventuristic but not hostile.

b. DV: ASD and Iraq

\footnotetext{
${ }^{818}$ See (note).

${ }^{819}$ WOODWARD, supra note 809 , at 45 (quoting 43).

${ }^{820} I d$. at 131 (quoting 43 in regard to the universalism of the moral values upon which U.S. foreign policy rests).

${ }^{821}$ VALENTY \& FELDMAN, supra note 226, at 90-96.

${ }^{822}$ WOODWARD, supra note 809, at 282.

${ }^{823}$ See VALENTY \& FELDMAN, supra note 226, at 91-93.

${ }^{824} \mathrm{Id}$. at $98-99$.

${ }^{825}$ VALENTY \& FELDMAN, supra note 226, at 99-101 (describing 43's "keen ability to read others' motives and desires").

${ }^{826}$ WOODWARD, supra note 809 , at 44.

${ }^{827}$ VALENTY \& FELDMAN, supra note 226, at 99.

${ }^{828}$ Id. at 95-96 (caution); id. at 102 (impulsivity).

${ }^{829}$ Id. at $98-99$
} 
In the aftermath of the horrific events of September $11^{\text {th }}, 2001$, the sobering prospect that enormously destructive nuclear, chemical, or biological weapons might be brought to bear upon its civilian population ${ }^{830}$ by suicidal terrorists living within its midst prompted the U.S. to undertake a dramatic revision of its national security strategy. ${ }^{831}$ The September 2002 National Security Strategy of the United States of America ${ }^{832}$ ["NSSUSA"], also known as the Bush Doctrine, warns transnational terrorists and rogue states that the U.S. has abandoned deterrence in favor of a robust and proactive strategic doctrine that sanctions the use of military force to eliminate threats posed by the intersection of WMD and an emerging breed of undeterrable adversaries ${ }^{833}$ before they can materialize. Specifically, the Bush Doctrine unmistakably claims the legal right to unilaterally preempt an incipient threat that, even if not yet operational, will, if permitted to mature, be reducible only at a much greater cost in lives and treasure. ${ }^{834}$ Immediately upon its promulgation the Bush Doctrine sparked a legal debate over whether the use of military force to prevent megaterrorism constituted one of the permissible exceptions to a general prohibition on the use of force in international relations. ${ }^{835}$ Iraq provided the test case.

In September 2002, 43 advised the UN that it might become necessary to employ force against Iraq to enforce existing Security Council resolutions and eliminate a threat to international peace and security. ${ }^{836}$ In response, the Security Council in November of that year adopted Resolution 1441, finding Iraq in "material breach" of obligations incurred under ceasefire agreements codified in a series of seventeen earlier Security Council resolutions, ${ }^{837}$ including the obligation, under Resolution 687, to disarm of weapons of mass destruction [“WMD”] ${ }^{838}$ For nearly a dozen years, Iraq had frustrated UN weapons inspectors and flouted the terms of the ceasefire, ${ }^{839}$ and with Resolution 1441 the UN threatened

\footnotetext{
${ }^{830}$ Fear that the terrorists responsible would attempt further attacks shaped the perceptions of the public and government decisionmakers in the aftermath of September $11^{\text {th }}$. WOODWARD, supra note 809, at 349.

${ }^{831}$ It may be impossible to overestimate the severity of the threat posed by the intersection of transnational terrorism and the proliferation of WMD. See KATHLEEN BAILEY, DOOMSDAY WEAPONS IN THE HANDS OF MANY 6 (1991) (describing this intersection as the gravest threat ever posed to U.S. national security); Roberts, supra note 800, at 483-84 ("The proliferation of weapons of mass destruction ... is one of the most significant and protracted threats to international security ... ever faced by mankind.").

${ }^{832}$ See National Security Strategy of the United States of America (September 2002) [“NSSUSA”], available at www. whitehouse.gove/nsc/nss.pdf.

${ }^{833}$ The Bush Doctrine contends that deterrence, predicated upon the maintenance of the threat that attacks against the U.S. will be met with an overwhelming response and thus redound to the detriment of the attacker, is ineffective against terrorists and rogue states who have no values against which the threat of force in response might counsel restraint. See id. at 15 (contending the "deadly threat of Islamic terrorists whose avowed tactics are wanton destruction and the targeting of innocents; whose so-called soldiers seek martyrdom in death," is not susceptible to deterrence).

${ }^{834}$ See id. (stating that the "immediacy of today's threats, and the magnitude of potential harm that could be caused by our adversaries' choice of weapons, do not permit ... let[ting] our enemies strike first."); see also NATIONAL STRATEGY TO COMBAT WEAPONS OF MASS DESTRUCTION 3 (Dec. 2002), at http:/www.whitehouse.gove/response/index/html ("Because deterrence may not succeed, and because of the potentially devastating consequences of WMD use against our forces and civilian population, U.S. military forces and appropriate civilian agencies must have the capability to defend against WMDarmed adversaries, including in appropriate cases through preemptive measures."); David E. Langer, Bush Renews Pledge to Strike First to Counter Terror Threats, N.Y. TIMES, Jul. 20, 2002, at A3 (reporting message from President Bush to U.S. troops in Afghanistan stating that the U.S. will preemptively strike against states developing WMD and that "America must act against these terrible threats before they're fully formed[.]").

${ }_{835}^{835}$ See Paust, supra note 799, at 533 (describing debates).

${ }^{836}$ See George W. Bush, UN General Assembly in New York City Address (Sept. 12, 2002), 38 WEEKLY COMP. PRES. DOC. 1529 (Sept. 16, 2002).

${ }^{837}$ SC Res. 1441 (Nov. 8, 2002), 42 ILM 250 (2003).

${ }^{838}$ See SC Res. 687 (Apr. 3, 1991), 30 ILM 846 (1991) (obligating Iraq to surrender its WMD and submit to verification inspections).

${ }_{839}$ In 1998, Iraq expelled UN weapons inspectors, and from 1998-2002 no enforcement was undertaken despite Security Council condemnation of the Iraqi expulsion. See SC Res. 1205 (Nov. 5, 1998) (condemning the expulsion as a "flagrant violation of resolution 687 and other relevant resolutions."). For a comprehensive discussion of efforts undertaken from 1991 to 1998 to
} 
"serious consequences" while allowing Iraq "a final opportunity to comply with its disarmament obligations[.]" ${ }^{\prime 40}$ Resolution 1441 required Iraq to submit, by 8 December 2002, "a currently accurate, full, and complete declaration" on its WMD programs, demanded that Iraq cooperate "immediately, unconditionally, and actively" with the UN, and stated that failure to do so would constitute an additional material breach. ${ }^{841}$ When Iraq failed to make the requisite declaration, ${ }^{842}$ Secretary of State Colin Powell, in February 2003, notified the Council of ongoing Iraqi efforts to obtain WMD. ${ }^{843}$

Despite the incontrovertible fact of the Iraqi material breach, U.S.-led efforts to prod the Security Council into further action were unsuccessful. ${ }^{844}$ A bloc led by France, Germany, and Russia insisted that yet another authorizing resolution was necessary to render an invasion of Iraq lawful on the theory that 1441 did not specifically authorize such an invasion and that the threat from Iraq was not sufficiently imminent as to justify military action. ${ }^{845}$ Quite simply, 43 disagreed and issued an ultimatum, stating that because "the power of Iraq to inflict harm on all free nations would be multiplied many times over" if enforcement action was not taken, the U.S. "choose[s] to meet that threat now, where it arises, before it can appear suddenly in our skies and cities. ${ }^{\prime 46}$ When the Hussein regime offered no response, on 19 March 2003 the U.S., under the code name OPERATION IRAQI FREEDOM [“OIF”], led an ad hoc coalition of the willing of about forty states into Iraq, defeated the Iraqi armed forces, and deposed the Hussein regime. ${ }^{847}$ On 1 May 2003, 43 announced the end of major combat operations, although lowintensity conflict continues at the time of this writing. The U.S. and allied states are currently in occupation of Iraq and preparing for a transfer of power and sovereignty to an elected Iraqi government on 30 June 2004. The Security Council has not imposed sanctions on participating states.

Even as it unfolded, OIF became the most hotly debated and contentious issue in international law, as well as the spark for mass public demonstrations. ${ }^{848}$ Scholars divided sharply. One camp was adamant that the threat posed by an Iraq armed with WMD, "either directly or through Iraq's support for terrorism, was sufficiently imminent to render the use of force necessary to protect the United States, its

enforce relevant Security Council resolutions regarding Iraq, see Ruth Wedgwood, The Fall of Saddam Hussein: Security Council Mandates and Preemptive Self-Defense, 97 AM. J. INT'L L. 576. 579-81 (2003).

${ }^{840}$ SC Res. 1441, supra note 838, at para. 2.

${ }^{841}$ Id. at para. 4.

${ }^{842}$ See Yoo, supra note 556, at 566 (describing Iraqi WMD declaration as "incomplete, inaccurate, and composed mostly of recycled information"); id. (("The conclusion is inescapable that at the time of the outbreak of the 2003 conflict, Iraq had decided to refuse to comply with its disarmament obligations.").

${ }^{843}$ See U.S. Secretary of State Colin Powell Addresses U.N. Security Council (Feb. 5, 2003), available at http://www.whitehous.gov/news/releases/2003/03/200302305-1.htm.

${ }^{844}$ Had the U.S. sought an additional authorizing resolution, there were inadequate votes in the Council. See Tom. J. Farer, The Prospect for International Law and Order in the Wake of Iraq, 97 AM. J. INT'L L. 621, 624 (2003) (indicating that fewer than 9 of the members of the Council would have voted in favor). France, Russia, and Germany were insistent that an additional resolution was necessary on the theory that the initial authorization, provided by Resolution 687, had expired at some point between 1991 and 2003, and that 1441 did not specifically provide that additional authorization. See Yoo, supra note 556, at 567 (discussing this position and arguing that it is incorrect as a matter of law). Security Council paralysis was thus the result of Franco-German and Russian insistence that yet another Resolution was required to authorize force in response to Iraqi failure to adhere to 1441, which resolution this triumvirate was certain to veto if proffered, and U.S. refusal to accept this position and seek another authorization. See Wedgwood, supra note 840, at 580.

${ }^{845}$ See generally Yoo, supra note 556 (describing the Franco-German-Russian legal arguments).

${ }^{846}$ Address to the Nation on Iraq, Mar. 17, 2003, 39 WEEKLY COMP. PRES. DOC. 338, 340 (Mar. 24, 2003).

${ }^{847}$ In launching the (re)invasion of Iraq, 43 pronounced that "The United Nations Security Council has not lived up to its responsibilities, so we will rise to ours." WOODWARD, supra note 809, at 354 .

${ }^{848}$ Richard Falk, What Future for the UN Charter System of War Prevention?, 97 AM. J. INT’L L. 590, 592 (2003). 
citizens, and its allies. ${ }^{, 49}$ Another held that the nature of the Iraqi threat was neither sufficiently imminent nor necessary to justify the use of force, ${ }^{850}$ that existing resolutions did not confer legal authority for invasion of Iraq, ${ }^{851}$ and that OIF thus "has about it an aura of ominous implication for international order[.]" ${ }^{\prime 852}$ Although OIF was arguably predicated upon far less controversial legal justifications, ${ }^{853}$ the characterization of the grounds for intervention for domestic political consumption by 43 as $\mathrm{ASD}^{854}$ along with a widespread perception that intervention could not be legally justified on any other basis, has thrust the ASD question to the fore; several commentators query whether OIF stands as an "international constitutional moment" ${ }^{\$ 855}$ that will prove decisive for the future of international law. ${ }^{856}$ Whereas, without conceding that intervention in Iraq was an act of preventive war, the U.S. and allied

\footnotetext{
${ }^{849}$ Yoo, supra note 556, at 574; see also Wedgwood, supra note 840, at 578 (defending use of force against Iraq as an exercise of ASD as well as "by the continuing effect of Security Council Resolutions 678 and 687"); Jane Stromseth, Law and Force After Iraq: A Transitional Moment, 97 AM. J. INT'L L. 628, 629 (2003) (characterizing this legal rationale as a "plausible argument”); MOORE, supra note 70, at 16 (concluding that the Iraqi failure to account for its WMD as required, its demonstrated use of WMD in the past, and its support for terrorism taken together justify invasion as a "defensive" measure); Bradford, supra note_ (arguing that 43 had a natural legal duty to defend U.S. nationals by invading Iraq).

${ }^{850}$ See, e.g., Falk, supra note 849, at 598; Sapiro, supra note 457, at 603.

${ }^{851}$ See Anne-Marie Slaughter, Good Reasons for Going Around the U.N., N.Y. Times, Mar. 18, 2003, at A31 (opining that "[m]ost international lawyers will probably reject this claim and find the use of force illegal under the terms of the [UN] Charter.”); Thomas Franck, What Happens Now? The United Nations After Iraq, 97 AM. J. INT'L L. 607, 613 (2003) (““"Neither the text nor the debates on the adoption of Resolution 687 reveal the slightest indication that the Council intended to empower any of its members, by themselves, to determine that Iraq was in material breach.").

${ }^{852}$ Farer, supra note 845 , at 626.

${ }^{853}$ Neither 43 nor the United Kingdom defined the March 2003 intervention against the Hussein regime as ASD but rather as a Chapter VII enforcement action with legal authority claimed under prior United Nations Security Council resolutions, specifically Resolutions 678 and 687 requiring, as a condition of the ceasefire negotiated in 1991, that Iraq permit inspections to verify disarmament. See President Says Saddam Hussein Must Leave Iraq within 48 Hours: Remarks by the President in Address to the Nation, March 17, 2003, at http://www.whitehouse.gov/news/releases/2003/03/20030317-7.html ["March 17 Address"]("Under Resolutions 678 and 687-both still in effect - the United States and our allies are authorized to use force in ridding Iraq of weapons of mass destruction."); Frances Gibb, Attorney-General Gives MPs Legal Basis for War, LONDON TIMES, Mar. 18, 2003, at 1 (quoting Attorney-General of the United Kingdom as stating "the government would be legally justified in declaring war on Iraq because of the combined effect of three UN resolutions[.]"); Letter from U.N. Ambassador John Negroponte to Ambassador Mamady Traore, President of the Security Council (Mar. 20, 2003),

http://www.usembassy.it/file2003 03/alia/A3032109.htm (providing U.S. position on legal justification and indicating primary focus on material breach of resolutions). Iraqi refusal to permit weapons inspections thus constituted a breach of the 1991 ceasefire and, under international law governing armistices, permitted belligerent parties to resume hostilities to secure the objectives specified under Resolutions 678 and 687. See Yoo, supra note 556, at 565-69 (analyzing international law of armistice and justifying OIF on the basis of Iraqi material breach of UN resolutions, by its refusal to permit good-faith inspections in 20022003, creating the conditions of the ceasefire) (referencing Iraqi ejection of weapons inspectors in October 1998 by the Security Council as a "flagrant violation of resolution 687 ... and other relevant resolutions[.]") (referencing SC Res. 1205, Nov. 5, 1998). Legal counsel for the U.S. Department of State supported these interpretations. See William H. Taft IV \& Todd F. Buchwald, Preemption, Iraq, and International Law, 97 AM. J. INT'L L. 557, 573 (2003) (describing OIF not as ASD but as the result of Iraqi material breach of resolutions, violation of ceasefire agreement, and the "final episode in a conflict initiated more than a dozen years earlier by Iraq's invasion of Kuwait"). Others disagree, suggesting, without conceding its lawfulness, that OIF cannot possibly be justified on any grounds other than ASD. See, e.g., Falk, supra note 849, at 592. For a thorough examination of the sources of legal support for OIF and for an argument that 43 did not characterize its action as ASD, see Sean D. Murphy, Assessing the Legality of Invading Iraq, 92 GEO. L. J. _ (forthcoming 2004).

${ }^{854}$ In his address to the nation on March 17, 2003, President Bush, although he referenced humanitarian considerations and selfdefense arguments as well as Iraqi violations of the 1991 ceasefire, rested his justification for the intervention largely on the ground that "[i]n 1 year, or 5 years, the power of Iraq to inflict harm on all free nations would be multiplied many times over" and that failure to "meet that threat now, where it arises, before it can appear suddenly in our skies and cities" would be an act of national "suicide." President George W. Bush, Address to the Nation on Iraq, Mar. 17, 2003, 39 WEEKLY COMP. PRES. DOC. 338, 340 (Mar. 24, 2003).

${ }^{855}$ See Anne-Marie Slaughter, An International Constitutional Moment, 43 HARV. INT'L L.J. 1, 2 ("Just as in 1945, the nations of the world today face an international constitutional moment.") (writing in response to the debate over the Bush Doctrine of preventive war in the context of the then-proposed Iraqi intervention).

${ }^{856}$ See Kofi Annan, Excerpt from Speech at the General Assembly, Sept. 23, 2003, at A11, available at http://www,nytimes.com/international (stating that the assertion of the right to engage in preventive war stands as "a moment no less decisive than 1945 itself, when the United Nations was founded."). Many observers concur with the assessment that the advent of the Bush Doctrine is, "[w]ithout question, the most pressing issue in the international realm." Addicott, supra note 444, at 754. See, e.g., Slaughter, supra note 856, at 2 ("Few events in global history can have galvanized the international system to action so completely in so short a time.") (quoting UK Foreign Secretary Straw).
} 
states claim the forcible ouster of the Hussein regime as a triumphal success that liberated the Iraqi people and rescued the credibility of the UN after an ignominious decade marked by failures to prevent famine, end genocide, and enforce the disarmament of rogue states, a chorus excoriates the decision to intervene absent Security Council imprimatur as a jurispathic act posing a grave threat not only to a half-centurylong commitment to multilateralism ${ }^{857}$ but to the international rule of law. ${ }^{858}$ Although the legality of OIC remains contested, ultimately the legitimacy of OIF, which has produced decidedly positive effects such as the ouster and capture of Saddam Hussein and the liberation of the Iraqi people from Ba'athist dictatorship, may turn on the success of the transition to Iraqi sovereignty: as Falk suggests, "If the American occupation is viewed as successful, then [OIF] is likely to be treated as 'legitimate[.]",859

\section{B. Analysis}

\section{Methodological Considerations and Limitations}

Although the relative underdevelopment of the field of international legal compliance dictates that the generation, rather than the analysis, of theories is the predominant focus at this stage of research, the ultimate objective remains the specification and testing of a theory with explanatory and predictive potential. However, generalization and testing of theories in social science typically require a large number of cases, and as a rule, as theoretical specificity and/or the complexity of the phenomenon under investigation increases, the number of cases available for analysis decreases. ${ }^{860}$ Some phenomena, including ASD, are so rare that there are insufficient cases to support the testing of general propositions with traditional methods of quantitative analysis; ${ }^{861}$ indeed, the universe of data available to answer the specific research questions posed by the present study is limited to ten cases. Moreover, phenomena that are causally linked to human agency and social processes are so complex or so rooted in specific contexts that quantitative methods "necessarily brush[] over the nuances" ${ }^{\$ 862}$ and render barren descriptions and inadequate explanations. ${ }^{863}$

\footnotetext{
${ }^{857}$ See Annan, supra note 857, at 11 (insisting that U.S.-led intervention against the Hussein regime has posed a "fundamental challenge" to multilateralism and to the role of the UN in preserving peace and security); see also Steven R. Weisman, An Audience Unmoved, N.Y. TIMES, Sept. 24, 2003, at A1 (reporting that French President Jacques Chirac has termed the legal division over the 2003 intervention as "one of the gravest threats to multilateral institutions in modern times"). Some go so far as to accuse the U.S. of seeking to "disable the United Nations" the better to rid the U.S. of "an international regime that is insufficiently responsive to both America's needs and the reality of U.S. disproportionate power" and establish an "American protectorate" in its stead. Franck, supra note 852, at 616, 617; Stromseth, supra note 850, at 637 (suggesting the Bush Doctrine will circumscribe the UN). Thus, for Franck et al., the Bush Doctrine represents a mortal threat to the international legal regime governing the use of force. Id. at 610 (blaming the U.S. for the "death" of international law governing the use of force); Bilder \& O'Connell, supra note 610, at 446 (resurfacing the suggestion that the international law governing the resort to force is moribund as a result of the Iraq intervention).

${ }^{858}$ See Lori Fisler Damrosch \& Bernard H. Oxman, Editor's Introduction, Agora: Future Implications of the Iraq Conflict, 97 AM. J. INT' L. 553, 553 (2003) (contending that "military action against Iraq in spring 2003 is one of the few events of the UN Charter period holding the potential for ... destruction of the system of law governing the use of force[.]"). The effect of noncompliance upon the continued vitality of international law, an issue raised but by no means answered by OIF, is the "most profound epistemological question" in the international law academy. Farer, supra note 845, at 621.

${ }^{859}$ Falk, supra note 849, at 594.

${ }^{860}$ See generally CHARLES TILLY, BIG STRUCTURES, LARGE PROCESS, HUGE COMPARISONS (1984).

${ }^{861}$ For reasons beyond the scope of this Article, a sample size of at least 30 cases is required if one hopes to place confidence in the results of multivariate statistics. Where there are too few cases to permit statistical analysis, as often there are in the study of international relations and foreign policy, other methods are necessary. See FALKOWSKI, supra note 242, at 104 (discussing the " $n$ " problem in foreign policy and international relations research).

${ }_{862}$ Hathaway, supra note 12 , at 1939-40.

${ }^{863}$ See KENNETH WALZ, THEORY OF INTERNATIONAL POLITICS 12 (describing quantitative methods as "inadequate" to the study of international relations due to its complexity and degree of organization).
} 
Although the behavioralist revolution of the 1950s continues to exert subtle pressure upon social scientists to transform these complex and contextually-sensitive social phenomena, including the general study of legal compliance, ${ }^{864}$ into empirical research questions "answerable" with multivariate statistics, ${ }^{865}$ quantitative analysis is not always appropos. ${ }^{866}$ Admittedly, quantitative, or variable-oriented, analysis does afford a rigorous method whereby to assess broad patterns of covariation across a wide range of cases. ${ }^{867}$ However, variable-oriented analysis is an inferential process that does not regard cases holistically or compare them directly to each other but rather treats them as the aggregates of a limited number of variables ${ }^{868}$ and generalizes from identifiable patterns of variance derived from the study of samples of relevant cases. By drawing a limited number of independent variables from their natural contexts and relegating all others to theoretical irrelevance, variable-oriented analysis forfeits the opportunity to develop an appreciation for and understanding of the role of human agency in the chain of causation. ${ }^{869}$ Moreover, the importune application of quantitative methods of analysis is deleterious to the accessibility and impact of the scholarly enterprise more generally: by displacing "softer" methods more appropriate to particular research agendae, variable-oriented analysis has played no small part in "detach[ing] [social science] from its surroundings and from audiences."

One of the most fundamental canons in the social and natural sciences is that the nature of the research question, rather than a particular methodological preference, should drive the design of experiments and the selection of methods of data analysis. When the subject of investigation is such that few cases exist, when the hypothesized chain of causation involves human agency and the social processes surrounding decisionmaking, and when outcomes are framed as the consequences of specific choices at unique decisional moments, a case-oriented approach, which treats cases, rather than variables, as the proper subjects of investigation, is best suited to the identification and incorporation of the broadest range of important independent variables in the development and testing of theories. Scholars of IHL compliance, a data-poor field in its infancy, are thus well-advised to heed those who urge researchers in pursuit of the relationship between law and decisionmaking to "discard . . statistical modeling" in favor of a "softer kind of empiricism." ${ }^{, 871}$ The herculean challenge for those who do is to identify a method that systematizes their labors and yields some degree of explanatory and predictive power while retaining rigor, logical consistency, communicability, generalizability, and parsimony.

\section{The Comparative Method}

\footnotetext{
${ }^{864}$ See, e.g., TYLER, supra note 139, at 58 (describing studies that applied multivariate statistical models to test the relationships between several independent variables and legal compliance).

${ }^{865}$ See MONROE, supra note 81, at 75 (describing paradigmatic shifts in empirical social science research from normativism to behavioralism and post-behavioralism).

${ }^{866}$ See Robert O. Keohane, Rational Choice Theory and International Law: Insights and Limitations, 31 J. LEG. STUD. 307,315 (criticizing the "hubris" of researchers "who believe that their command of mathematically difficult techniques provides them with a unique key to the nature of social reality.").

${ }^{867}$ See CHARLES RAGIN, THE COMPARATIVE METHOD 53 (1987) (describing the virtues of quantitative, or "variableoriented," methods of social science).

${ }^{868}$ The structural limitations of variable-oriented analysis are such, for reasons beyond the scope of this Article, that it cannot exhaust the entire range of IVs and must instead select a limited number for statistical analysis. See id. at 59 (discussing the selectivity that variable-oriented analysis must employ in the study of IVs).

${ }^{869} I d$. at 53, 62-70 (discussing the shortcomings of variable-oriented analysis).

${ }^{870} I d$. at 171.

${ }^{871}$ Goodman \& Jinks, supra note 15, at 184.
} 
The case-oriented approach, also known as the "comparative method," fosters an extensive dialogue between ideas and data by relying upon comprehensive historical research and interrogation of data to guide the identification of important causal factors while simultaneously regarding each case as a holistic entity and comparing it directly with every other case. ${ }^{872}$ Comparative researchers compare and contrast combinations of casual factors in one case setting with different combinations in another setting and, through a process of systematic "eyeballing," identify patterns of similarity and difference in the distribution of outcomes associated with various factorial combinations. ${ }^{873}$ Comparativists then apply the "method of agreement" to identify which of the possible causal factors is constant across all cases of a particular outcome or phenomenon and thereby discover degrees of isomorphism between seemingly unrelated cases. While the comparative method does not necessarily prove a cause and effect relationship, it does create an important point of departure for experimental research. ${ }^{874}$ As formalized and applied to the present study, the comparative method treats each personality construct as a causal factor/independent variable and each outcome as a dependent variable.

\section{Formalization: Qualititative Comparative Analysis}

\section{a. introduction}

In the natural scientific community it has long been regarded as axiomatic that events do not simply happen but instead occur only under certain precisely delimited conditions. Formal scientific methods, including laboratory experimentation, led researchers to find that the outcome of combustion requires the presence of oxygen, that microbes were responsible for infectious disease, and that an absence of Vitamin C caused scurvy. Similarly, Qualititative Comparative Analysis ["QCA"] rests upon this fundamental axiom of causation that undergirds the scientific method. QCA is constructed upon the premise that, short of formal experimentation, which is nearly impossible in the social sciences due to ethical and logistical constraints, formal logic, particularly the process of induction, is essential to determine the necessary and sufficient causal factors of particular outcomes in research settings characterized by a scarcity of cases.

b. causal factors and outcomes

Specifically, QCA, an analytical methodology developed to aid the investigation of social science questions grounded in human agency and beset with methodological problems resulting from a paucity of cases, permits the investigator of a particular DV, or "outcome," to identify, through detailed historical research and interpretation of all existing cases of the outcome, a broad number, "n", of probable IVs, or "causal factors."

\footnotetext{
${ }^{872}$ See generally RAGIN, supra note 868 (presenting the first comprehensive description of the case-oriented method as a method of analysis in the social science under the rubric "the comparative method")..

${ }^{873} I d$. at 13.

${ }^{874} \mathrm{Id}$. at 36.

${ }^{875}$ The term "causal factor" is a misnomer, since although it is possible to establish associative relationships between independent and dependent variables through application of QCA it is difficult, if not impossible, to demonstrate causation. An associative relationship is simply a statement that the presence of an independent variable tends to occur in connection with the presence of a dependent variable; it does not mean that the dependent variable is necessarily caused by the independent variable, although a causal inference may be drawn. Proof of causation, however, requires controlled experimentation to prove that the independent variable, rather than some intervening or confounding variable, causes the dependent variable to occur and that the association between variables is not simply one of covariance. See generally David Freedman, From Association to Causation: Some Remarks on the History of Statistics, Technical Report No. 521 (Jan. 2002), available at http://stat-
} 
cases. Each case is examined for the presence or the absence of the causal factor; the presence of the causal factor is indicated by a capital letter, e.g., "A," while the absence is indicated by a lower-case letter, e.g., "a." ${ }^{, 876}$ In any QCA analysis, the possible number of combinations of causal factors is thus $2^{\text {n }}$. c. necessary and sufficient conditionality

Each of the $2^{\mathrm{n}}$ cases is placed in a matrix, known as a "truth table," that illustrates the associations of particular outcomes with particular combinations of causal factors that manifested in actual historical cases. Where cells in the truth table are unfilled due to an absence of the particular combination in the historical record, experimental research is required to augment history and exhaust all possible combinations of causal factors. ${ }^{877}$ While it is asking too much of the method to expect it to yield completely unproblematic and generalizable laws on the basis of very few cases, QCA nonetheless specifies relationships of necessity and sufficiency between causal factors and outcomes that hold across the entire universe of extant cases and that in turn serve as the basis for future experimentation. A "necessary" causal factor is one that always precedes a given outcome/effect and in the absence of which the outcome/event cannot occur, while a "sufficient" causal factor is a factor in the presence of which a given outcome/effect must occur. ${ }^{878}$

d. prime implicants

After the specification of necessary and sufficient causal factors, QCA employs Boolean algebra ["BA"], a mathematical system that uses symbols and set theory to represent logical operations in algebraic form, ${ }^{879}$ to reduce several different combinations of causal factors productive of the same outcome(s) to what are known as "prime implicants." ${ }^{800}$ In formal logic terms, an "implication" is formed when two statements are combined by placing the word "if" before the first and "then" between them, e.g., "If I drink this glass of water, then my thirst will be quenched." In an implication, the component statement between the words "If" and "then" is known as the "antecedent" and, alternatively, as the "implicans;" the statement which follows the word "then" is known as the "consequent" and, alternatively, as the "implicate." An implication asserts that its antecedent implies its consequent; thus, if

www.berkeley.edu/ census/521.pdf. For example, although smoking is associated with increased rates of lung cancer and can be demonstrated through experimental research to cause lung cancer, alcohol consumption is not associated with increased rates of lung cancer, and smoking and alcohol consumption are associated (smokers drink more than nonsmokers). Therefore, alcohol consumption is associated with increased rates of lung cancer although it does not cause increased rates of lung cancer. Simply put, association does not imply causation.

${ }^{876}$ Boolean algebra ["BA"] cannot accept interval data and mandates dichotomous scoring of constructs. An interval scale would enable more precise measurements of the dimensions of each decisionmaker on each personality construct. See, e.g., FELDMAN \& VALENTY, supra note 228, at 24 (scoring decisionmakers from 1.0 to -1.0 on each personality construct). However, doing so would render the resulting analysis too complex for BA techniques.

${ }^{877}$ See J.J.M.M. RUTTEN ET AL., MATHEMATICAL TECHNIQUES FOR ANALYZING CONCURRENT AND PROBABILISTIC SYSTEMS 97-100 (discussing Boolean analysis of probabilistic statements and organization of data). ${ }^{878}$ See GLEN SATTY ET AL., COMPUTING AND LOGIC MATHEMATICS AND LANGUAGE 129-30 (1988) (discussing principles of necessity and sufficiency in formal logic and their application to research). For example, to produce the outcome of starting an automobile it is a necessary causal factor for the gas tank to contain gasoline, but it is not a sufficient causal factor: one may not have keys, the battery may be discharged, or the engine may be damaged. On the other hand, in order to achieve the desired outcome of preventing the automobile from starting it is a sufficient causal factor to simply either empty the gas tank, lose the keys, or discharge the battery.

${ }^{879}$ See generally GEORGE BOOLE, AN INVESTIGATION OF THE LAWS OF THOUGHT ON WHICH ARE FOUNDED THE MATHEMATICAL THEORIES OF LOGIC AND PROBABILITIES (1854) (elaborating the theory of BA). Until recently, applications were limited to the fields of formal logic, design and analysis of computers, and pure mathematics, but BA has recently been imported into social science to study, e.g., trade union growth and decline and explanations for revolutionary successes and failures. See_ INT'L J. COMP. SOC. (1991)

${ }^{880}$ See RAGIN, supra note 868, at 59. 
the statement "I drink this glass of water" is true, it is also true that "my thirst will be quenched." In short, the essential meaning is the relationship asserted between the antecedent and the consequent: if the antecedent is true, the consequent is also true.

Implication does not suggest, in the case of the example, that it is not possible to satisfy thirst in any other manner, nor does implication imply that there may not be other outcomes attendant to the drinking of the glass of water: in fact, beer may satisfy my thirst, or the water may be poisoned, and thus although it serves the function of quenching thirst it may also produce death. Nonetheless, implication does establish a definitive relationship between the antecedent and the consequent.

A "prime implicant" is special type of implication in which the antecedent is the minimum combination of causal factors which together are either 1) sufficient to cause a particular outcome or 2) necessary to cause a particular outcome across the universe of possible cases and the consequent is the particular outcome. Thus, for any given outcome $y$ for which there is a prime implicant $x$, if $x$ is a true statement of existing causal factors then either 1) $y$ must occur as a result of the existence of $x$ or 2) $x$ is a prerequisite for the production of $y$. A prime implicant for any given outcome can be identified by (1) surveying the universe of cases in which that outcome is expressed and eliminating each of the " $n$ " causal constructs for which there is more than one possible value from the causal construct combinations associated with that particular outcome. Those constructs that remain in every case in which the outcome is expressed together constitute the prime implicant for that outcome. Through determination of prime implicants it is possible to isolate the particular necessary and/or sufficient causal factors, if any, which produce the given outcome(s) over the universe of available cases.

e. probabilities: hypothetical analysis

When the historical record fails to exhaust all possible combinations of causal factors it is impossible to specify necessary and sufficient causality in respect of particular outcomes. Under such circumstances QCA directs the investigator to analyze preliminary hypotheses regarding the relationships between causal factors and outcomes to derive probabilistic propositions than can serve as points of departure for experimental research. For example, consider the phenomenon of "successful social revolution," which has occurred three times in history. In all three cases the causal factor of a "collapsing monarchy" was present, but in only two-the Russian Revolution of 1917 and the Chinese Revolution of 1949 — was the causal factor of "strong charismatic leadership" present. In the third- the French Revolution of 1789-it was absent. ${ }^{881}$ Accordingly, while "collapsing monarchy" is a necessary condition for social revolution, "strong charismatic leadership" is not. However, the preliminary hypothesis, "The stronger and more charismatic the leader of the revolutionary element, the more successful the resulting social revolution," is supported or affirmed by 2 of 3, or 66.7\%, of cases, as is the probabilistic statement, "A successful social revolution will be led by a strong and charismatic leader."

4. QCA Applied to the Association of Personality Constructs and ASD Outcomes

a. personality constructs as causal factors

${ }^{881}$ See generally THEDA SKOCPOL, STATES AND SOCIAL REVOLUTIONS (1979) (identifying and analyzing the French (1789), Russian (1917), and Chinese (1949) revolutions as the sole instances of social revolution in history). 
The four personality constructs, each of which is a causal factor and an independent variable, are labeled as follows:

1. militarism: A (presence of construct/factor) or a (absence of construct/ factor);

2. anomism: B (presence of construct/factor) or b (absence of construct/factor);

3. hostility: C (presence of construct/factor) or c (absence of construct/factor);

4. adventurism: D (presence of construct/factor) or $\mathrm{d}$ (absence of construct/factor).

Table 1, "Personality Profiles," aggregates the personality construct scores to create personality profiles for each HD in each of the ten historical cases.

b. association of outcomes with personality profiles

The presence of each outcome/DV in a particular historical case is scored as "1," while its absence is scored "0." Table 2, "Personality Profiles with Associated ASD Outcomes," associates the presence or absence of each of the ten outcome with each personality profile. As Table 2 illustrates, the incidence of particular outcomes associates with the following personality profile(s), the first step in the determination of prime implicants:

(1) consideration of ASD as an option: $\mathrm{ABCD}, \mathrm{ABCd}, \mathrm{aBCD}$, abcd, aBcd, Abcd, and $\mathrm{ABcD}$;

(2) selection of ASD: aBCD, abcd, $\mathrm{ABCD}, \mathrm{Abcd}$, and $\mathrm{ABcD}$;

(3) defense of an exercise of ASD: aBCD, abcd, ABCD, Abcd, and ABcD;

(4) defense of an exercise of ASD on legal grounds: aBCD, abcd, ABCD, Abcd, and ABcD;

(5) other actors regard an exercise of ASD as lawful at the time of its exercise: Abcd;

(6) other actors regard an exercise of ASD as legitimate at the time of its exercise: $\mathrm{aBCD}$, Abcd, and

$\mathrm{ABcD}$;

(7) state engaging in ASD is subject to legal sanctions: ABCD;

(8) other actors regard an exercise of ASD as lawful and/or legitimate in retrospect: aBCD, abcd, ABCD, Abcd, and $\mathrm{ABcD}$;

(9) decisionmaker who ordered his/her state to engage in or refrain from ASD would make the same decision again in hindsight: $\mathrm{ABCD}, \mathrm{ABCd}, \mathrm{aBCD}$, abcd, $\mathrm{Abcd}$, and $\mathrm{ABcD}$; and

(10) exercise of ASD can fairly be said to have contributed to world order: ABCD, ABCd, aBCD, abcd, $\mathrm{Abcd}$, and $\mathrm{ABcD}$.

c. prime implicants of ASD outcomes

The "other actors regard an exercise of ASD as lawful at the time of its exercise" outcome and the "state engaging in ASD is subject to legal sanctions" outcome are each associated with a single personality profile, Abcd and ABCD respectively. Therefore, each profile is a prime implicant for its associated outcome. However, for the eight other outcomes it is not possible to identify a prime implicant, as for each personality construct the presence and absence of the construct associates with each outcome in at least one personality profile. Furthermore, given the limited number of cases of ASD it is premature to conclude that any construct(s) are sufficient, rather than simply necessary, conditions for the production of any given ASD outcome. The sole exception is the hypothetical instance of an outcome for which there is a single personality profile as the prime implicant across the entire range of $2^{4}$, or sixteen, possible personality profiles, yet in the universe of historical cases of ASD, only seven personality profiles-ABCD, ABCd, aBCD, abcd, aBcd, Abcd, and ABcD—have been associated with ASD outcomes. Where, as here, the history of ASD has not exhausted all possible combinations of causal factors and it is therefore impossible to specify necessary and sufficient causality with regard to particular outcome, QCA directs the investigator to undertake hypothetical analysis to derive probabilistic statements and outcome maximizing combinations. 


\section{d. hypothetical analysis}

An initial qualitative analysis yields little to confirm or reject most of the PHs. As Table 3, "Analysis of Preliminary Hypotheses," illustrates, no PH is affirmed by all or zero of the ten cases. Nonetheless, if there were no relationship between any of the personality constructs and any of the outcomes, chance would predict that each hypothesis would be affirmed by fifty percent of cases and rejected by fifty percent of cases. ${ }^{882}$ To affirm a particular PH for purposes of this study, an arbitrary determination is made that it must be supported by at least sixty percent of cases in which the outcome is expressed, ${ }^{883}$ in order to be able to reject a particular $\mathrm{PH}$, and to affirm the alternate hypothesis expressing the inverse relationship of the causal factor and outcome in question, ${ }^{884}$ it must be affirmed by forty percent or fewer of the cases in which the outcome is expressed. This requirement establishes a sufficiently significant improvement over chance such that some measure of confidence can be placed in those PHs affirmed or rejected at this threshold. As Table 3, illustrates, of the forty PHs,, nine are affirmed by sixty percent or greater of cases (\#s 1, 2, 9, 10,11, 13, 15, 29, and 32), and six are affirmed by forty percent or fewer (\#s 12, 14, 22, 30, 35, and 39).

The following reformulated hypotheses, stated as working propositions [“WPs"], as well as their obverses (negation of both personality construct score and outcome score), are offered at this stage of theoretical development:

WP \#1 (hypothesis \#1): A militaristic decisionmaker will consider ASD;

WP \#2 (hypothesis \#2): A militaristic decisionmaker will engage in ASD;

WP \#3 (hypothesis \#9): A militaristic decisionmaker will be satisfied with his/her decision regarding whether to engage in ASD;

WP \#4 (hypothesis \#10): A militaristic decisionmaker will make a decision in regard to whether to engage in ASD that supports world order;

WP \#5 (hypothesis \#11): An anomistic decisionmaker will consider ASD;

WP \#6 (hypothesis \#12): An anomistic decisionmaker will not engage in ASD;

WP \#7 (hypothesis \#13): An anomistic decisionmaker will defend the exercise of ASD;

WP \#8 (hypothesis \#14): An anomistic decisionmaker will defend the exercise of ASD on legal grounds;

WP \#9 (hypothesis \#15): An anomistic decisionmaker's decision to engage in ASD will not be regarded as lawful by other actors;

WP \#10 (hypothesis \#22): A hostile decisionmaker will not engage in ASD;

WP \#11 (hypothesis \#29): A hostile decisionmaker will be satisfied with his/her decision regarding whether to engage in ASD;

WP \#12 (hypothesis \#30): A hostile decisionmaker will make a decision in regard to whether to engage in ASD that supports world order;

WP \#13 (hypothesis \#32): An adventuristic decisionmaker will engage in ASD;

WP \#14 (hypothesis \#35): An adventurist's decision to engage in ASD will not be regarded as lawful by other actors; and

WP \#15 (hypothesis \#39): An adventuristic decisionmaker will be satisfied with his/her decision regarding whether to engage in ASD.

i. analysis of associative relationships

\footnotetext{
${ }^{882}$ For a discussion of the theory of probability and the role of chance, see CHARLES M. GRINSTEAD \& J. LAURIE SNELL, INTRODUCTION TO PROBABILITY ( ${ }^{\text {nd }}$ ed. rev. 1999).

${ }_{883}$ On some DVs no outcome is expressed in several cases: i.e., where a decisionmaker does not elect to engage in ASD, no question of the lawfulness or legitimacy of the decision is raised, and thus no score is expressed on either outcome. Thus, rather than establish a specific number of cases in which the hypothesized relationship must obtain, a percentage is used in recognition of the fact that fewer than ten cases are available in regard to several of the dependent variables.

${ }^{884}$ For example, suppose the hypothesis "The more sunny the day is the fewer people on this beach will experience sunburn" is determined to be true in 1 of 10, or 10\%, of cases studied (perhaps because on the one sunny day only Bahamians were on the beach, while on cloudy days Norwegians were in attendance). The alternate hypothesis, "The more sunny the day is the more people on this beach will experience sunburn" is accepted as true in 9 of 10 , or $90 \%$, of cases.
} 
a. militarism and ASD

WPs 1 and 2, both affirmed by 60\% of cases, seem intuitively obvious. We anticipate that nationalistic patriots with military experience and a favorable view of power who are keenly ambitious, inflexibly committed to a view of the international system as a zero-sum competition for survival, unable or unwilling to integrate contrary information or to seek and heed the counsel of others, and convinced that foreign policy is an arena in which they must aggressively battle to prove their worth to consider and elect options, including ASD, that involve the use of force against rivals perceived to threaten the interests of the states at their command, even if such options are controversial and even if the nature or magnitude of the threat is uncertain. Information that confirms the nature and magnitude of a threat is consistent with the worldview of the militarist and is credited as valid, whereas information that would discredit the threat or suggest a non-conflictual or less conflictual response is discarded. The militarist must defend the patria from attacks, which loom everywhere and which afford his reason for being, and any means, even if considered by other actors as unacceptable, unlawful, or disproportionate, is legitimate to this end.

WP 3 is somewhat more surprising. To the extent that extreme militarists are incorrigibly convinced that the international system is an arena of perpetual conflict, incapable of considering nonmilitary instruments of policy, and unable to refrain from tasking the national armed forces to serve their ambitions and prove their worth, it stands to reason that they would evaluate their decisions to engage in ASD uncritically and learn little if anything from military failure, political criticism, or legal sanctions. However, that militarists tend to be satisfied in the rectitude of their decisions in regard to the exercise of $\mathrm{ASD}$, and that non-militarists tend to regret their decisions, suggests that in circumstances where an arguably imminent threat has arisen it may indeed be prudent to respond with ASD, and militarists are more prone to do so than non-militarists.

WP 4, affirmed by $70 \%$ of cases, is even more unanticipated. The restrictivist camp regards IHL as very much a prohibitory regime and treats the use of force as ipso facto unlawful unless authorized by the Security Council $;{ }^{885}$ the entire framework of the UN Charter, a document born out of the horror of World War II and intended to create a more peaceful and just international system, ${ }^{886}$ is erected upon the moral premise that armed conflict is a scourge as well as the legal commitment to the principle that force is no longer to be used to resolve disputes. ${ }^{877}$ That force, applied in anticipation of armed attacks, should actually prove supportive of international order and justice, and that militarists, for whom force is the preferred instrument of policy, should make a greater contribution to this end than non-militarists seems, at least on its face, to pose a challenge to the moral philosophy and legal theory underlying restrictivism. b. anomism and ASD

WP 5 is, as anticipated, affirmed by $70 \%$ of cases. Decisionmakers who are ignorant and even disdainful of law and legal authorities and bereft of an internal moral code will naturally regard international legal regulations on the resort to force in purely instrumental terms and afford them little if

\footnotetext{
${ }^{885}$ See supra at $p p_{-}$(describing the restrictivist position with regard to ASD).

${ }^{886}$ See UN Charter, supra note 440, at art. 1 (1-3).

${ }^{887}$ See id. at Preamble, art. 2(3).
} 
any independent weight in the decisionmaking regarding whether to engage in ASD. If ASD can conceivably protect their states from an external threat, anomistic decisionmakers will consider ASD whether consistent with or contrary to the law. Similarly, that anomists' decisions to engage in ASD would be regarded by other actors as unlawful, as WP 9 states and as $71.4 \%$ of cases affirm, is unsurprising. Anomists' disregard for law, authority, and moral considerations are expressed not only in the substantive content of their decisionmaking but in the process whereby they negotiate and interact with other actors and explain and justify their decisions. An anomist's decision to engage in ASD, as well as his or her explanation and justification for that decision, is likely qualitatively distinct from a similar decision and the accompanying explanation or justification offered by a non-anomist.

WP 6, however, is completely counterintuitive. An anomist is precisely the personality expected to engage in ASD notwithstanding any legal prohibitions to the contrary, and the finding, supported by $60 \%$ of cases, that anomists do not engage in ASD, is difficult to explain. By contrast, although WPs 7 and 8 , both affirmed by $71.4 \%$ of cases, are also counterintuitive, it bears noting that all decisionmakers, regardless of personality profiles, defended their actions when resorting to ASD, and all made legal arguments; it it is at least as plausible to suggest that all decisionmakers reflexively seek to justify their actions on a legal basis when engaging in the use of force as it is to suggest that anomism is associated with the legal defense of the exercise of ASD.

c. hostility and ASD

It might be expected that self-absorbed, delusional, amoral decisionmakers who distrust and dislike humanity and reject any limits on the means that may be used to defend against the welter of threats they believe surround them would be strongly inclined to lash out with force against outsiders regardless of provocation or of the consistency of such a response with legal obligations. Strangely, $60 \%$ of the cases affirm WP 10, which states that a hostile decisionmaker will not engage in ASD. It is difficult at this stage of theory development to specify why this may be so: it may be that hostility is no absolute bar to the exercise of prudent discretion, or that other actors are more cautious in their dealings with hostile decisionmakers and refrain from conduct that might be perceived as threatening. If the latter, it might be questioned whether the manifestion of hostility has the effect of inoculating decisionmakers, at least to some degree, against the machinations of other actors who choose on that basis not to make states led by hostile decisionmakers the targets of their designs.

WP11, just as WP 3, is curious. Although sixty percent of cases affirm that a hostile decisionmaker will be satisfied with his or her decision regarding whether to engage in ASD, it might have been anticipated that the self-absorption, unmotivated distrust, detachment from reality, and hatred for others that govern ideal-typic hostile decisionmakers would warp their judgments and yield decisions they would ultimately come to regret. However, considered in conjunction with WP 10, which states that hostile decisionmakers, in contrast to militarists, refrain from engaging in ASD, the high degree of satisfaction indicated by WP 11 may be explained on the ground that hostile decisionmakers are somehow able to prevent their hostility from coloring their decisionmaking. In the same vein, proposition 12, which links hostility with decisions regarding ASD that support world order, may simply be a reflection 
of the tendency of hostile decisionmakers to refrain from engaging in acts of ASD that, if they were to give rein to their hostility, would otherwise not be predicated upon genuine threats to their states but would rather be malignant expressions of their narcissism, ethnocentrism, Machiavellianism, or other subconstructs of their hostility.

\section{d. adventurism and ASD}

WP 13, affirmed by $60 \%$ of cases, states rather plausibly that anxious, impulsive gamblers who reposit great faith in their capacity to assert their will upon events are willing to undertake a military strategy that affords the prospect of significant benefits while nonetheless presenting significant risks in terms of the political consequences should other actors regard the resort to ASD as a violation of law. For adventurists, the risks associated with ASD are outweighed by the potential gains. WP 14, however, affirmed by $71.4 \%$ of cases, implies that other actors are disinclined to regard the adventurist favorably, and that the risk-taking propensity of the adventurist may be perceived as inherently and diametrically opposed to the predictability that many members of the international community hope to secure by way of the rule of law. Still, WP 15, affirmed by $60 \%$ of cases, suggests that there are important gains to be had even if they come at a price: although adventurists may be regarded as law-breakers when they engage in ASD, they regard their decisions to do so as having been correct under the circumstances. Success in international relations, particularly if defined as the defense of the state against external threats, may well require some risk taking

\section{ii. Outcome Maximizing Combinations}

Although only two ASD outcomes are linked to prime implicants, several other outcomes are associated with a number of personality profiles that, although they cannot be reduced to prime implicants, share at least one personality construct score across at least $60 \%$ of the profiles associated with those outcomes. For example, $\mathrm{PH} \# 10$, "The more militaristic a decisionmaker, the more likely his/her decision with regard to ASD can fairly be said to have contributed to world order," is supported by seven of ten, or $70 \%$, of cases, while six of eight, or $75 \%$, of personality profiles associated with the presence of the outcome "contributed to world order" contain the personality construct "A," "militaristic," and thus reinforce PH \#10. ${ }^{888}$ As Table 4, "Personality Constructs with Associated ASD Outcomes," illustrates, twenty-two associations satisfy the $60 \%$ confidence level.

An "Outcome Maximizing Combination" ["OMC"] can be determined for each ASD outcome. Each OMC represents that construct or aggregation of constructs that yields the greatest probability, relative to all other constructs or aggregates, of an association with a particular outcome. Each construct for which hypothetical analysis yields at least a $60 \%$ probability of association with a particular outcome is included in the OMC for that outcome. For example, for "consider ASD," PH \#1, "The more militaristic a decisionmaker the more likely s/he will be to consider ASD," is supported by $60 \%$ of cases, and PH \#11, "The more anomistic the decisionmaker, the more likely s/he will be to consider ASD," is supported by $70 \%$ of cases. Therefore, the presence of the constructs "militarism" and "anomism," indicated by the score $\mathrm{AB}$, is part of the OMC. However, $\mathrm{PH} \# 21$, "The more hostile the decisionmaker

\footnotetext{
${ }^{888}$ Cases in which the outcome is not expressed are not included in modified QCA.
} 
the more likely s/he will be to consider ASD," is supported by only $50 \%$ of cases-the equivalent of chance-as is PH \#31, "The more adventuristic the decisionmaker the more likely s/he will be to consider ASD." Consequently, neither the presence nor absence of either hostility or adventurism is included in the OMC for "consider ASD."

The following are the OMCs for each of the ten ASD outcomes:

(1) consider ASD: AB;

(2) engage in ASD: AbcD;

(3) defend exercise of ASD: b;

(4) defend exercise of ASD on legal grounds: b;

(5) exercise of ASD regarded as lawful by other actors: bd;

(6) exercise of ASD regarded as legitimate by other actors: none;

(7) exercise of ASD met with sanctions: none;

(8) exercise of ASD regarded as lawful or legitimate in retrospect: none;

(9) decisionmaker is satisfied with the outcome of the ASD decision: ACD; and

(10) ASD decision promoted world order: AC.

e. Probabilistic Statements of Association

A "Probabilistic Statement of Association" ["PSA"] is a synthetic statement of association between a personality construct or profile and ASD outcome(s) demonstrated to be true across a minimum of $60 \%$ the ten historical cases in hypothetical analysis as well as across a minimum of $60 \%$ of the cases in which the outcome(s) is/are expressed ["outcome occurrences"] in QCA. Although PSAs establish to a reasonable degree of confidence the existence of relationships of association between personality constructs and ASD outcomes, they do not imply the absolute truth or validity of the associative relationship, nor do they identify the microprocesses that "produce" associated outcomes. A given instance of ASD can yield outcomes divergent from the explanations and predictions offered by PSAs. Nonetheless, given current methodological and theoretical constraints, PSAs are perhaps the fullest extent to which rigorous analysis can be extended.

The five PSAs are as follows:

(1) A militarist is more likely to consider ASD than a non-militarist; this PSA is supported by 6 of 10 cases $(60 \%)$ in hypothetical analysis and by 6 of 10 outcome occurrences in QCA for an average probability of .600;

(2) A militarist is more likely to be satisfied with his/her decision regarding whether to engage in ASD than a non-militarist; this PSA is supported by 8 of 10 cases (80\%) in hypothetical analysis and by 6 of $8(75.0 \%)$ outcome occurrences in QCA for an average probability of .775;

(3) A militarist is more likely to make a decision in regard to whether to engage in ASD that supports world order than a nonmilitarist; this statement is supported by 7 of 10 cases $(70.0 \%)$ in hypothetical analysis and by 6 of 8 (75.0\%) outcome occurrences in QCA for an average probability of .725;

(4) A non-anomist's decision to engage in ASD will be more likely to be regarded as lawful by other actors than an anomist's decision to engage in ASD; this statement is supported by 5 of 7 cases (71.4\%) in hypothetical analysis and by 1 of $1(100 \%)$ outcome occurrences in QCA for an average probability of .857; and

(5) A non-adventurist is more likely to make a decision regarding whether to engage in ASD that is regarded as lawful by other actors than an adventurist; this statement is supported by 5 of 7 cases $(71.4 \%)$ in hypothetical analysis and by 1 of $1(100.0 \%)$ outcome occurrences in QCA for an average probability of .857.

The five PSAs assess explanatory and predictive probabilities for four of the ten outcomes; for example, PSAs 4 and 5, taken together, indicate that in the event that a non-anomistic and nonadvenuristic decisionmaker engages in ASD, the probability that the decision will be regarded by other 
actors as lawful is $85.7 \%$, whereas the likelihood that the exercise of ASD by an anomistic and adventuristic decisionmaker will be judged lawful is $14.6 \%$. No PSAs can be deduced on the basis of existing data for the remaining six ASD outcomes.

\section{Combined Theoretical Model}

In Figure 1, "Formal Theoretical Model," the solid, single-headed arrows indicate an associative relationship between personality constructs and ASD outcomes. An attempt is made to distinguish the strengths of the associative relationships by labeling each arrow with a coefficient ranging from - 1.00 to 1.00: a relationship of perfect positive association is accorded a coefficient of 1.00 whereas a relationship of perfect negative association is accorded a coefficient of -1.00 . This measurement of coefficients is analogous to the correlational coefficients used in statistical analysis; however, true measurement of correlation is not feasible given the very small " $n$ " available to the current study. Consequently, relationships of association are employed in the manner of correlation coefficients to much the same end. In the case of an arrow connecting a construct to an ASD outcome that is labeled with a positive coefficient, the presence of the personality construct associates with the ASD outcome to which it is connected (the obverse of this stated relationship is also true). For an arrow labeled with a negative coefficient the absence of the personality construct associates with the ASD outcome to which it is connected (again, the obverse of this relationship is also true). Note that only those associative relationships with coefficients that round to greater than or equal to .6 or lesser than or equal to -.6 are included in the formal theoretical model; the complete absence of any associative relationship would dictate an coefficient of .5 for the linkage between the U.S. Presidential personality construct and the unrelated outcome as well as -.5 for the linkage of the absence of the personality construct and unrelated outcome.

"Coefficients of associative relationships" are measured by calculating the average of the percentage of the cases in hypothetical analysis supporting a particular associative relationship between a personality construct and a particular ASD outcome and the percentage of outcome occurrences in QCA in which the associative relationship is evidenced between the construct and the outcome. Coefficients are illustrated in Table 5, "Coefficients of Associative Relationships."

\section{General Observations and Caveats}

Perfect explanation and prediction of human decisionmaking in a complex situation characterized by stress and lack of information transcends not only the reality of the current state of science but also the expectations of all but the most optimistic. The present theory is intended to offer some tools for explanation and prediction, but attempts to read the proverbial crystal ball for insight into concrete future outcomes in instances in which the prospect of ASD arises will prove less than completely satisfying at best. Despite the identification of numerous associative relationships, it is important to stress the limited and conditional nature of the causal significance of personality. Each and every decisionmaker in the present study considered, and seven of ten elected, ASD. These findings suggest that the personality constructs under analysis may be less significant than other variables, whether unidentified personality constructs, objective analyses of external threats, the absence of reliable multilateral institutions that can 
be enlisted to maintain peace in lieu of self-help, or the lack of credible and effective legal sanctions to deter unilateral and unauthorized action, in inducing decisionmakers to contemplate and elect ASD.

Moreover, all decisionmakers who engaged in ASD defended their decisions, and all grounded their justifications upon legal arguments. This finding calls into question whether personality plays a significant role in determining whether, and on what basis, states justify their resort to ASD, and may suggest instead that the defense of ASD on legal grounds is simply a rational strategic accompaniment that all but the clinically insane offer as a veneer for their actions, however thin, to minimize attendant political and legal costs. Furthermore, the resort to ASD is almost uniformly regarded by a decisionmaker's contemporaries as unlawful: in only a single instance-41's intervention in Panamawas an act of ASD contemporaneously adjudged as lawful. That ASD should be deemed unlawful in nearly all instances suggests that the legal judgment of the international community may be unrelated to the personalities of the decisionmakers, a group of individuals endowed with a range of diverse personality profiles, electing the strategy. Similarly, the general failure to sanction acts of ASD points toward factors other than personality, such as the incapacity or unwillingness to organize collective military sanctions or uncertainty as to the precise substantive content of the formal legal rules, as responsible for the failure to require compliance.

Six of seven instances of ASD are regarded in retrospect as lawful and or legitimate, and eight of ten decisions regarding whether to engage in ASD left decisionmakers satisfied and contributed positively to world order. These findings suggest that the international community has, with the passage of time, come to regard a practice it considered unlawful upon commission to be not merely lawful but, in effect, the proper strategy under the circumstances. This in turn suggests not that personality is irrelevant but rather that legal judgments regarding ASD may perhaps be so amenable to contemporaneous politicized interpretation and contestation that the existing legal regime, to the extent it inhibits the exercise of ASD by decisionmakers who, whether as a consequence of the influence of their personalities upon their decisionmaking or for some other reason, would have engaged in ASD, is dysfunctional.

\section{Criticisms, Responses, and Directions for Future Research}

Despite grounds for caution, this study has identified several associative relationships between personality and various ASD outcomes, and one should not be too quick to discount the causal significance of personality to IHL compliance at this juncture. Nonetheless, there are sure to be criticisms of the present theory on any number of bases.

\section{A. Criticisms}

\section{Reductionism}

Those with intellectual commitments to theories that regard other levels of analysis as more fundamental to the explanation of the behavior of states may dismiss personality as little more than "a magic slogan to charm away the problems that [their] intellectual tools don't handle." 889 Others, without categorically rejecting its causal significance, may take exception to the claim that personality, rather than the role of the foreign policy or military bureaucracies, domestic interest groups, the political or cultural

\footnotetext{
${ }^{889}$ HERBERT SIMON, ADMINISTRATIVE BEHAVIOR (1947).
} 
nature of the state, or the distribution of military or economic power in the international system, is central to explanations for state decisions concerning compliance with IHL; for these critics, personality constructs are simply "noisy" variables, and the reductionism of personality-based theories is invariably sacrificial of explanatory and predictive power. ${ }^{890}$

\section{Lack of Parsimony}

Still others, even if convinced that personality is relevant to the explanation of state compliance with IHL, may fault the present theory on the ground that it is insufficiently parsimonious to be accessible to a wide array of researchers that would otherwise wish to replicate and build upon its conclusions. Personality theories are difficult to subject to empirical testing, and researchers must expend a great deal of labor, time, and resources to acquire specific knowledge about the subjects of investigation as well as requisite training in psychobiographical research, qualitative methodology, and formal modeling. ${ }^{891}$

\section{Ecologically Fallacious}

Finally, some may simply find the present theory perilously close to committing the ecological fallacy of presuming that associative, or even causal, relationships that obtain within a very small " $n$ " of cases are generalizable to the universe of potential decisionmakers. Indeed, there may be another set of personality constructs that generates better explanatory and predictive power, and it is possible that other researchers engaged in replication studies will score decisionmakers differently and reach contrary findings. Moreover, the prospect that a future clarification of the law regarding ASD may render the legal regime more or less definitive may have implications for compliance decisionmaking and in turn for the present theory.

\section{B. Responses}

\section{Reductionism}

The "perfect" model of compliance with the IHL regime governing ASD might well treat state behaviors as resulting from a combination of causes and in turn amalgamate insights and variables from all pretheories and all levels of analysis. However, such a model would be so cumbersome and so difficult to conceptualize and apply that some reductionism would be necessary to permit other researchers to engage in the critical tasks of replication and falsification. However, neither the naïve view of IHL compliance as the mere projection of personalities nor the belief that decisionmaking is entirely insulated from the effects of personality enjoys empirical support. If state behaviors could be explained solely by reference to the personalities of decisionmakers there would be no discernible pattern of behavior at variance with predictions derived from the analysis of those personalities. The data do not

\footnotetext{
${ }^{890}$ See, e.g., MOORE, supra note 70, at xxi (suggesting that the "core determinants" of decisions to engage in war, and behavior during war, are not "somehow psychological or personal, but rather a[re] the locus of meaningful operation of the powerful determinants operating to affect incentives at the governmental and international system levels."). The predominant pre-World War II view was that the primary causes of war and peace were to be found in the personalities of statesmen. See E.H.CARR, TWENTY YEARS' CRISIS ix (1939) (taking exception to this predominant paradigm). Because much of international relations scholarship over the past six and one-half decades has been oriented, however indirectly, toward disproving the causal significance of personality, the resurrection of personality as the fundamental level of analysis in international relations is bound to provoke criticism. Scholars in other legal issue-areas are similarly resistant to the notion that explanations for behavior lurk in individual personalities. See, e.g., Donald A. Dripps, Fundamental Retribution Error: Criminal Justice and the Social Psychology of Blame, 56 VAND. L. REV. 1383, 1391 (2003) (cautioning against overestimation of the extent to which personality determines compliance with criminal law).

${ }^{891}$ See SEARS ET AL., supra note 78, at 257 (explaining reasons for reluctance to explore personality-based approaches).
} 
support this conclusion, and the present study does not make this assertion. By the same token, personality is not epiphenomenal to IHL compliance: although there may be some circumstances in which any decisionmaker facing the precise set of conditions will decide identically, decisions as to whether to engage in ASD appear to be influenced, if not entirely determined, by personality. Because personality is causally relevant to the explanation and prediction of IHL compliance, the proposed theory is not remiss for taking personality seriously.

Whether, however, a theory of IHL compliance can fairly be branded as overly reductionist for focusing narrowly upon the causal significance of personality to the neglect of variables from other levels of analysis remains an open question. ${ }^{892}$ While it is possible to incorporate multiple levels of analysis within a single theory, it is also possible, by building too many variables drawn from too many levels of analysis into a model, for theoretical eclecticism to become hobgoblin to explanatory and predictive power. Explanations of phenomena grounded in a single level of analysis are not reductionist per se, and reductionist explanations are not necessarily unhelpful: it is only when explanatory and predictive power is sacrificed to accommodate the objective of theoretical simplicity that this criticism is warranted.

Rather than blindly commit to spareness in the abstract, the responsible scholar "evaluates the relative utility—conceptual and methodological—of the various alternatives open to him, and . . appraise[s] the manifold implications of the level of analysis finally selected." ${ }^{, 893}$ Research in the newly-coined field of law and neuroeconomics ${ }^{894}$ suggests that the ultimate locus of decisionmaking is the series of neurochemical processes in the human brain that drive individuals to seek "rewards" and avoid "punishments" at least partially independently of their cognitive or affective perceptions and beliefs. ${ }^{895}$ If neural mechanisms are indeed responsible for theoretically significant aspects of human behavior, then the argument that IHL compliance decisions can be explained and predicted by investigation of personality alone is not a convenient reductionist gambit but rather a sound conceptual and methodological commitment that can only benefit from an even more micro-level analysis of the biological constituents of personality.

\section{Lack of Parsimony}

No theory attempting to offer policy-relevant explanations and predictions of compliance with the IHL regime governing ASD, a contextually-bound phenomenon of great complexity, is likely to be described as parsimonious. This is particularly true of a theory the development and testing of which requires the acquisition of substantive and methodological training that imposes entry barriers to research and renders it less accessible and replicable than theories predicated upon more familiar levels of analysis. If parsimony, rather than explanatory and predictive power, is the measure of success, there would be

\footnotetext{
${ }^{892}$ See, e.g., MOORE, supra note 70, at 42-43 (suggesting that although "[w]e should keep before us ... the ... probability" that theories designed to explain state behaviors with regard to armed conflict "might be further usefully refined by adding psychological profiles of particular leaders, and systematically applying findings of cognitive psychology[,]" the incorporation of psychological variables should be supplementary to, rather than instead of, variables derived from the structure of states and from the international systemic distribution of power).

${ }^{893}$ J. David Singer, The Level of Analysis Problem in International Relations, 14 WORLD POL. 77, 77 (1961).

${ }^{894}$ See Terrence Chorvat, Kevin McCabe, \& Vernon Smith, Law and Neuroeconomics, SSRN WPS \#501063 (2004) at 3 (coining the term "law and neuroeconomics," concluding that neural mechanisms are responsible for behavior, and suggesting that neurochemistry delineates the limits of law to alter behavior).
} 
grounds for concern. However, "[w]hen all other things are not equal, as is usually the case, we prefer an accurate complexity over an inaccurate parsimony." explanatory and predictive power as can be corralled at present, it behooves those who would challenge its lack of parsimony to instead commit to the development of the research and experimental techniques that will enable greater collaboration in the field of PT.

\section{Ecologically Fallacious}

Generalizing inductively from a very small number of cases is inherently problematic, for anomalous individual cases are more likely to drive findings than they will in larger populations. However, because the data employed herein constitutes the universe of historical instances of ASD it is not a sample, and thus no inferences need be drawn that might build upon skewed data. Moreover, the propositions, findings, and conclusions of the present study are conditional and intended to serve as an explanation for a very limited number of context-dependent cases of ASD and even more importantly as the point of departure for further research, rather than as a final and authoritative statement of the relationship between personality and IHL compliance. Personality profiles remain unexhausted, and only future experimental research and the passage of time can remedy this defect. The external validity and usefulness of any theory will ultimately be judged by subsequent efforts at replication and falsification, and by history. ${ }^{897}$ At present we must content ourselves with a rigorous yet methodologically imperfect initial investigation that yields probabilistic and conditional findings.

\section{Comparison to Other Theories}

Perhaps the best defense of the proferred personality theory of IHL compliance against criticism is a comparison of the explanations it offers in regard to the empirical data with the explanations and predictions derived from the alternative pretheories. If PT is more congruent with observable patterns of decisionmaking than alternative pretheories, then notwithstanding its reductionism or lack of parsimony there is cause to believe that the theory that will ultimately render the most sophisticated explanations and predictions will, at the very least, incorporate personality.

a. realism

Because nothing but the relative distribution of power is theoretically significant to realism and neither law nor personality bears upon the behavior of self-interested states in an anarchic system, realism explains all decisions regarding compliance with IHL in terms of power. ASD permits a state to maximize its defensive power, and in the absence of a central executive with the capacity to enforce order, even weak states, when threatened by other states, will always engage in ASD either singly or jointly with other, more powerful allies to whom they promise services and benefits in exchange for their assistance.

\footnotetext{
${ }^{895}$ See, e.g., Piotr Winkielman \& Kent Berridge, Irrational Wanting and Subrational Liking: How Rudimentary Motivational and Affective Processes Shape Preferences and Choices, 24 POL. PSYCH. 657, 673 (2003).

${ }^{896}$ WALZ, supra note 47 , at $113 \mathrm{n} .13$ (defending a theory of international relations grounded in variables drawn from the systemic level of analysis against the potential charges of reductionism and lack of parsimony).

${ }^{897}$ "Replication" is process whereby future researchers employ independently collected data to study the same empirical phenomenon and compare results to the findings of the earlier study, while "falsification" is the process whereby scholars employ inductive reasoning to disprove core premises or assumptions of a theory. See Paul S. Herrnson, Replication, Verification, Secondary Analysis, and Data Collection in Political Science, 28 PS POL. SCI. \& POL. 452 (1995). For a discussion of the importance of replication to the enterprise of empirical legal scholarship, see generally Gregory Mitchell, Empirical Legal Scholarship as Scientific Dialogue, 83 N. C. L. REV._ (2004, forthcoming).
} 
Realism thus predicts, contrary to empirical observations, that in every instance, or $100 \%$ of the time, regardless of the personality of the HDs at their helms, states will consider and engage in ASD yet feel no compulsion to defend their decisions on legal or other grounds.

\section{b. ET}

ET, although it maintains that an appropriate package of sanctions can in theory be crafted to deter states from threatening their neighbors and thereby obviate the resort to ASD, concedes that states will engage in ASD unless the threat of sanctions is sufficient to deter them. Because the Security Council is singularly ineffective as a collective security mechanism, and because only the U.S. has the sort of hegemonic power that is necessary to enforce IHL, ET would seem to yield not only the general prediction that threatened states are obligated in every instance- $100 \%$ of the timeindependently of the personalities of their HDs but that the U.S., and states to which the U.S. extends guarantees of defense assistance, will never be subject to the sort of threats that will render ASD necessary. Both predictions are controverted by empirical evidence.

c. liberalism

Liberalism assumes that the nature of the state is dispositive of patterns of compliance with law and that liberal democracies are much more likely to comply with the regime governing ASD than nonliberal states. If true, one would expect that at least a significant number of instances of resort to ASD would be undertaken by illiberal states, and one might predict that when liberal states engage in ASD their decisions to do so will be more likely to be regarded as lawful or at least legitimate. The data do not support any of these hypotheses. The U.S. and Israel - two liberal democracies - are the sole states to have engaged in ASD; put differently, no illiberal state has ever engaged in ASD, and $100 \%$ of the states that have done so-compared to liberalism's prediction of $0 \%$--have been liberal democracies. Moreover, in only one of seven instances- $14.3 \%$ of the cases - was an exercise of ASD by either of these two states deemed lawful by the international community, an outcome that runs counter to the liberal prediction that democracies would comply with the law and, at least as importantly, be adjudged to be in compliance as a general rule.

\section{d. RCT}

RCT predicts simply that if ASD is the battle strategy most likely to yield the greatest benefits to a threatened state, the state, through its HD, will choose to engage in ASD regardless of his individual personality; conversely, if ASD is less likely than another strategy to maximize relative wealth and power, states will refrain. Under objectively threatening conditions of a certain magnitude, every HD, according to RCT, will elect ASD. Should a HD refrain from ASD, RCT assumes that the threat was not sufficiently severe and that an alternative battle strategy was more effective. Although each instance of ASD is historically unique and thus difficult for RCT to organize into a coherent and consistent explanation, retrospectively RCT can only conclude that whether a state engaged in or refrained from ASD it was rational for the HD to have made the decision; in other words, RCT offers no testable predictions. RCT, due to its presumption of inherent rationality, is even less equipped to offer insight into 
why states defend the exercise of ASD, how other actors evaluate the exercise of ASD, or whether an exercise of ASD contributes to world order.

e. managerialism

By presuming that states are inherently interested in cooperation, MT is auto-relegated to nearirrelevance in the development of theories of IHL compliance, as utterly uncooperative a venture as is imaginable. To the extent that MT is of any utility to theorizing in the issue-area of ASD, perhaps it can explain the fact that all decisionmakers defend their exercise of ASD on legal grounds as simply an expression of the universal desire of states to cooperate, and to appear to be cooperative, in their relations with other states (a core prediction of RT) as well as a generalized commitment to law as the medium wherein to facilitate cooperation.

\section{f. RT}

RT, which assumes that states value a reputation for compliance as an independent end, is largely irrelevant as well, for states threatened with extinction privilege their survival above all else. RT is, along with managerialism, better suited to other issue-areas of international relations. To the extent that RT is taken seriously as the basis for prediction of state behaviors in regard to ASD, one might anticipate that those states most generally committed to the rule of law-a group that includes the Western liberal democracies and Israel-would be those least inclined to run afoul of the IHL regime governing ASD. That the U.S. and Israel are the only two states that have engaged in ASD suggests that whatever reputational costs are incurred through resort to ASD are minimal in relation to the gains and that reputation is of limited significance in the issue-area of armed conflict.

\section{g. TLP}

TLP predicts that state compliance with IHL is a function of the degree of incorporation of IHL within the domestic legal regimes; those states that best internalize IHL obligations within their municipal law will demonstrate the highest levels of compliance. Accordingly, because it is the most sophisticated military powers that have developed the most detailed and comprehensive codes of military regulations to incorporate IHL obligations, TLP predicts that the leading martial states, including the U.S. and Israel, should be far less likely than states with little military prowess and little formal domestic military regulation to engage in ASD; yet quite the opposite is true: the only states that have engaged in ASD — the U.S. and Israel—are among a very small and select group of states that have precisely-elaborated military codes and well-articulated institutions of military justice. ${ }^{898}$

\section{h. LT}

LT offers no testable theory of IHL compliance: it is simply a general statement that states tend to comply with IHL because law is perceived as legitimate. If, however, LT is correct in asserting that states comply with laws that they perceive as legitimate, then instances of non-compliance must be treated as symptoms of legal illegitimacy. Because no state or individual officially regards the formal regime

\footnotetext{
${ }^{898}$ See Christopher Greenwood, Military Rule-Making: Military Manuals and Other Administrative Rules Relating to Armed Conflict, Report to International Colloquium at Bad Hamburg, Germany (June 17-19, 1988), in NATIONAL IMPLEMENTATION OF HUMANITARIAN LAW 193-96, 197 (Michael Bothe, ed. 1990) (offering comparative assessment of degree of internalization of IHL by various states in their military manuals and distinguishing a core group of Western liberal democracies as significantly more advanced than all other states).
} 
governing ASD as illegitimate, however-states and individuals adopt varying interpretations of obligations arising under the Charter and under customary IHL, but none disclaim the legitimacy of the regime-LT must either predict perfect compliance with the regime or account for which individuals and/or states regard IHL as illegitimate and why they do so, craft a more subtle explanation for the linkage between compliance and legitimacy sympathetic to multiple interpretations of legal obligation and correspondingly differential standards of compliance with the law giving rise to that obligation, and explain how differential perceptions of legal obligation and legal legitimacy translate into outcomes. History disproves the prediction of perfect compliance, and LT as presented limits an expanded account that considers degrees of legitimacy while prescribing agnosticism regarding the cognitive, affective, and perceptive milieux of individuals.

i. constructivism

Constructivism presumes that compliance follows ineluctably from the dissemination and inculcation of norms favoring compliance within the preference structure of states and key individuals and the codification of these norms in the content of legal regimes. Accordingly, constructivism predicts that HDs will adhere to widely-shared normative understandings of appropriate behavior regarding the resort to force, with cooperative and rule-governed conduct prevailing over power and self-interest. However, even if one accepts that cooperative norms trump self-interest to the extent they succeed in (re)constructing state and individual preferences, constructivism does not offer any account for how norms transform preferences, for which norms are best descriptive of widely-shared preferences at any given decisional point or, more importantly, for why some individuals fail to embrace a particular code of normative content and why some act contrary to legal prescriptions and proscriptions even when they purport to accept the normative basis for a given legal regime. Constructivism simply predicts, contrary to empirical evidence, that individuals can be induced to prefer to comply and thus will in fact comply with law generally and with the IHL regime governing ASD specifically; it does not offer a theory that can be subjected to traditional methods of analysis or to experimental research.

\section{j. OCT}

The use of force in anticipation of an attack is a battle strategy that has always been perfectly consistent with the normative structure of the martial code. ${ }^{899}$ If IHL compliance is a function of the degree of congruence between the formal rules of relevant legal regimes on the one hand and the organizational culture of the military bureaucracy on the other, as OCT theorizes, then, because a pragmatist interpretation of the formal rules is available that permits the exercise of ASD, OCT predicts that states will consider and engage in ASD each and every time they are credibly threatened with attack regardless of the personalities of their HDs. However, although in each case ASD was considered, there have been three cases where decisionmakers in states with military organizational cultures favorable to the exercise of ASD elected not to make the decision to preempt attack. Moreover, if OCT provided an adequate account of state and individual preferences, decisions to engage in ASD ought not be contemporaneously regarded by other states as unlawful and illegitimate, as so often they have been. 
Because OCT predicts that (1) decisionmakers will engage in ASD at a 100\% rate and that other actors will almost invariably and contemporaneously regard each exercise as (2) lawful and (3) legitimatepredictions at odds with empirical data indicating rates of $70 \%, 14.3 \%$, and $42.9 \%$ respectively-a theory that transcends the cultural level of analysis to develop the fine thread of personality running through the OCT explanation is necessary.

\section{Summary}

Although the probabilistic statements of association and linkage between personality constructs and ASD outcomes offered in the present study are necessarily tentative at this stage of theoretical development, PT, although arguably reductionist and non-parsimonious, harnesses greater explanatory and predictive power and offers a more complete and consistent account for a range of ASD outcomes than existing pre-theories of international legal compliance.

\section{Directions for Future Research}

1. Experimental Research

a. experimental personality profiles

Although it would be premature to draw conclusions about causation on the basis of the associative relationships identified across ten historical cases of ASD decisionmaking, a clear agenda for future research emerges. As Table 6, "Universe of Personality Profiles," illustrates, there have been a total of only seven distinct combinations of the four personality constructs identified in the present study as causal factors of ASD outcomes. However, as QCA indicates, these four personality constructs generate a total of $2^{4}$, or sixteen, possible combinations. Consequently, as Table 7, "Experimental Personality Profiles," illustrates, there are nine combinations of the four constructs that exist theoretically within a sufficiently numerous population but cannot as yet be identified, analyzed, placed in a truth table, and incorporated in the present theory. When, as here, the historical record fails to exhaust all possible combinations of causal factors it is impossible to specify necessary and sufficient causality in respect of any particular outcome unless the historical record can be augmented either the passage of time and the availability of additional real-world crises wherein the question of ASD arises, or by the production of additional cases in an experimental setting. Data associated with experimental profiles and derived from simulation research can then be integrated with historical data and subjected to QCA.

b. experimental typologies

Much might be learned from the analysis of these experimental personality profiles, which, as Table 8, "Experimental Profiles with Predictions of Associated Outcomes," illustrates, are assigned the following typologies to reflect the associative relationships anticipated in respect to each: ${ }^{900}$

\footnotetext{
${ }^{899}$ See William Bradford, Barbarians at the Gates: A Post-September $11^{\text {th }}$ Proposal to Rationalize the Laws of War, 79 NOTRE DAME L. REV. _ (forthcoming).

${ }^{900}$ The seven combinations that comprise the historical record can also be assigned the following typologies: (1) ABCD ("The Barbarian"), (2) ABCd ("The Counterpuncher"), (3) aBCD ("The Reluctant Barbarian"), (4) abcd ("The Moralist"), (5) aBcd ("The Ostrich"), (6) Abcd ("The Sheriff"), and (7) ABcD ("The Friendly Barbarian"). For a discussion of the use of typologies to classify decisionmakers on the basis of their personality construct combinations, see, e.g., FALKOWSKI, supra note _, at 19-21 (describing characteristics of the "expansionist," the "active independent," the "influential," the "mediator," the "opportunist," and the "participator").; Winter et al., supra note 263, at 223 (describing characteristics of the "opportunist" and the "developmental" personalities).
} 
(1) AbCD ("The Soldier"): The Soldier will consider, engage in, and defend ASD on legal grounds, and will be satisfied with his/her decision regarding ASD, which will in turn contribute to world order. There is insufficient evidence to anticipate whether the decision of the Soldier to engage in ASD will be regarded as lawful or legitimate either contemporaneously or in retrospect and whether the decision will be sanctioned;

(2) AbcD ("The Merchant"): The Merchant will consider, ${ }^{901}$ engage in, and defend ASD on legal grounds, and will be satisfied with his/her decision regarding ASD. There is insufficient evidence to anticipate whether the decision of the Merchant to engage in ASD will be regarded as lawful or legitimate either contemporaneously or in retrospect, whether it will be sanctioned, and whether it will contribute to world order;

(3) aBCd ("The Malcontent"): The Malcontent will consider but will not engage in ASD, and s/he will not be satisfied with this decision. There is insufficient evidence to anticipate whether the decision not to engage in ASD will contribute to world order;

(4) abCD ("The Mediator"): The Mediator will neither consider nor engage in ASD. ${ }^{902}$ Whether or not s/he does engage in ASD s/he will be satisfied. If s/he does engage in ASD, s/he will defend the exercise of ASD on legal grounds, but there is insufficient evidence to anticipate whether other actors will regard the decision as lawful or legitimate either contemporaneously or in retrospect, or whether the decision will contribute to world order;

(5) ABcd ("The Independent"): The Independent will consider ASD, but there is insufficient evidence to anticipate whether s/he will engage in ASD and whether the decision will contribute to world order. If s/he engages in ASD s/he will not defend the decision, and there is insufficient evidence to anticipate whether the decision to engage in ASD will be regarded as lawful either contemporaneously or in retrospect, or whether the decision will be sanctioned. S/he will not be satisfied with the decision.

(6) AbCd ("The Sentry"): There is insufficient evidence to anticipate whether the Sentry will consider or engage in ASD, but if s/he does engage in ASD s/he will defend the decision on legal grounds, and the decision will be regarded as lawful and legitimate contemporaneously and in retrospect. ${ }^{903}$ No sanctions will be applied to the Sentry's decision to engage in ASD. Whether or not the Sentry engages in ASD, s/he will be satisfied with the decision, and the decision will contribute to world order;

(7) aBcD ("The Jellyfish"): There is insufficient evidence to anticipate whether the Opportunist will consider ASD, but s/he will not engage in ASD. S/he will not be satisfied with the decision to refrain from ASD, which will not contribute to world order;

(8) abcD “The Follower”): The Follower will neither consider nor engage in ASD. S/he will not be satisfied with the decision to refrain from ASD, which will not contribute to world order;

(9) abCd ("The Hermit"): The Hermit will neither consider nor engage in ASD. S/he will not be satisfied with the decision to refrain from ASD, which will not contribute to world order.

The results of further research should reinforce or undermine the predictions regarding associations between personality and ASD outcomes, enable the elaboration of a formal theoretical

\footnotetext{
${ }^{901}$ Although the results of OMC analysis do not shed light on whether The Merchant is likely to consider ASD, because each and every historical decisionmaker considered ASD, and because The Merchant is likely to engage in ASD, it is assumed that s/he will have considered ASD before electing it as a policy decision.

${ }^{902}$ Although the results of OMC analysis suggest that there is insufficient evidence to anticipate whether the Mediator will engage in ASD, because the Mediator will not consider ASD it is logically impossible that s/he will engage in ASD.

${ }_{903}$ Although OMC analysis indicates that there is insufficient evidence to anticipate that the decision of the Sentry to engage in ASD will be regarded as legitimate, because the decision will be regarded as lawful, and because lawfulness is presumed to be a more difficult burden to meet than legitimacy, it is presumed that the decision of the sentry to engage in ASD will be regarded as legitimate. Moreover, although there is insufficient evidence to anticipate that the Sentry's decision to engage in ASD will be regarded as lawful and/or legitimate in retrospect, because as the historical record indicates the perception of lawfulness and legitimacy is more likely to arise in retrospect than contemporanously, the presumption is that an exercise of ASD judged lawful and legitimate contemporaneously will remain so in retrospect.
} 
model, and serve as a springboard to yet further, and perhaps even more generalizable, research.

Simulation research offers a potentially fruitful route to this end.

2. Simulate Data

a. simulation research

In brief, "simulation" is the dynamic modeling of central features, relationships, and social processes of the natural world that facilitates the direct observation and rigorous testing of complex systems that are difficult or impossible to access with other methodologies. ${ }^{904}$ By rendering otherwise inaccessible systems susceptible to investigation, simulation is indispensable in the linkage of historical and experimental research in the development and testing of theories across a broad range of diverse social and natural science subfields. ${ }^{905}$ Although simulation does not allow for direct examination or incorporate all aspects of the referent system and is thus not a true experimental methodology, it has tremendous heuristic value. ${ }^{906}$ Variables can be readily identified and manipulated, substantive propositions of theoretical importance can be derived and tested, and data can be rapidly generated for incorporation with other data sets and subsequent analysis. ${ }^{907}$

In the typical international relations simulation, human subject participants, selected on the basis of some discrete personality or experiential characteristics determined through psychological profiling, ${ }^{908}$ are assigned to national teams ${ }^{909}$ and placed in a setting where constraints and incentives resemble the referent world. A scenario-a detailed account of the sequence of political, military, and legal events leading up to a specific crisis or confrontation ${ }^{910}$ - is used to goad participants to manipulate resources and make decision in pursuit of their exogenously and endogenously defined objectives. ${ }^{911}$ Only the independent variables are prescribed through the selection of participants on the basis of their psychological profiles, their assignment to specific teams, and the allocation of specific political, economic, and military capabilities to each team through the scenario. The decisions of the participants in response to the scenario and to the decisions of other participants—-the dependent variables — are

\footnotetext{
${ }^{904}$ See generally HAROLD GUETZKOW, SIMULATION IN INTERNATIONAL RELATIONS (1963) (defining and discussing simulation as an experimental research heuristic and developmental methodology); URS LUTERBACHER \& MICHAEL D. WARD, EDS., DYNAMIC MODELS OF INTERNATIONAL CONFLICT 252 (1985) (noting that simulation is ideally suited to the rigorous analysis of "complex decision problems in concrete settings").

${ }^{905}$ See Robert Mandel, Political Gaming and Foreign Policy Making During Crises, 29 WORLD POL. 610, 614 (1977) (theorizing that high-level decisionmaking during conditions of stress is univestigable save for by simulation); SANDOLE, supra note 322, at 46 (describing simulation as the "best format for the controlled investigation of behavior"); E.W. PAXSON, WAR GAMING 33 (1963) (stating that simulation offers scholars the opportunity to "make major contribution[s] to the pressing questions which cannot await refinements in methodology.").

${ }_{906}^{90}$ Se, e.g., GUETZKOW, supra note 905, at 7 (stressing that most simulations should be incorporated into the discovery phase of science building as simulation is difficult to validate).

${ }^{907}$ See HERMAN, supra note 336, at 167 (describing utility of simulation as a method for generating data and testing theories); SANDOLE, supra note 322, at 48 (noting utility of simulation research to replication and validation studies).

${ }^{908}$ See GUETZKOW, supra note 905, at 92-94 (describing assignment of participants on the basis of psychological profiles); HERMANN, supra note 243, at 4-11 (discussing selection and assignment of simulation participants on the basis of participant responses on psychological instruments); KNUTSON, supra note 288, at 327-35 (discussing creation of psychological instruments to test, select, and assign participants on the basis of research protocols).

${ }^{909}$ The number of participants and teams, and the determination and assignment of specific roles to team members, is determined by the research question. See CHARLES HERMANN, CRISES IN FOREIGN POLICY 46, 46 n.14 (1963).

${ }^{910}$ See HARVEY A. DEWEERD, A CONTEXTUAL APPROACH TO SCENARIO CONSTRUCTION 3 (1973) (describing the role of the scenario in simulation research).

${ }^{911}$ See CHARLES WALCOTT, ED., SIMPLE SIMULATIONS II: A COLLECTION OF SIMULATION/GAMES FOR POLITICAL SCIENTISTS 1-3 (1980).
} 
entirely unregulated, and together with the personality profiles of the participants these decisions, and their consequences, constitute the experimental data.

Comparisons between the behaviors of "real world" decision makers and simulation participants are essential in establishing confidence in simulation as a research method in the study of international legal compliance. ${ }^{912}$ While for some the "leaps to the laboratory" from real world settings may seem "nonsensical," research produces experimental data isomorphic to the referent world. ${ }^{914}$ Complete isomorphism is impossible-an exact one-to-one relationship would require that the simulation be as large and complex as the reality it represents-and because some aspects of any given phenomenon are irrelevant to a particular research question a simulation need capture only the key features of the referent system or process. Still, a high degree of isomorphism is necessary if simulations are to motive participant decisions that have "real world" character, and although it is inevitable that some features of the "real world" will be excluded, if the results of a simulation and either the informed intuitive expectation of a future event or the results of a historical event have a similar structure and form, that simulation stakes a prima facie claim to validity. ${ }^{915}$ In fact, extensive evidence suggests that simulation research does indeed produce results highly isomorphic to reality. ${ }^{916}$

\section{b. Project CLAW}

In brief, Project Compliance with the Laws of War ["PROJECT CLAW"] is a scenario-driven simulation of a politico-military crisis designed by the author to generate additional cases of decisionmaking with regard to the ASD outcomes under analysis in the present study. Participants will be selected on the basis of their personality profiles, as determined by an assessment instrument, and other relevant criteria. Participants will be assigned to roles on several national teams, including one which will be subjected by the scenario to an imminent military threat and whose HD will possess one of the nine experimental personality profiles. Nine simulation runs will be conducted during the spring and summer of 2005, and the resulting experimental data will be integrated with the historical data and subjected to QCA analysis and, where appropriate, "harder," more quantitative methods. By exhausting all possible personality profiles and integrating analysis of simulate and historical data, PROJECT CLAW will generate greater confidence in the validity of the resulting associative relationships between personality and ASD outcomes, enable the specification of necessity and conditionality, and permit the

\footnotetext{
${ }^{912}$ HERMANN, supra note 336, at 167; see also Joyner, supra note 304, at 332 (describing use of simulation of international legal decisionmaking as an educational method and indicating that the success of the exercise depends upon the degree to which participants assume their roles and the extent to which their decisionmaking is isomorphic with the decisionmaking of real world participants in the foreign policy decisionmaking process).

${ }_{913}$ H. GUETZKOW \& J.J. VALDEZ, SIMULATED INTERNATIONAL PROCESSES: THEORIES AND RESEARCH 326 (1981).

${ }^{914}$ GUETZKOW, supra note 905 , at 136.

${ }^{915}$ GUETZKOW \& VALDEZ, supra note 914, at 63, 256.

${ }^{916}$ See, e.g., WALCOTT, supra note 912, at 121 (finding significant isomorphism between decisionmaking in simulation and in actual historical cases); Dina A. Zinnes, A Comparison of Hostile Behavior of Decision-Makers in Simulate and Historical Data, 18 WORLD POL. 474, 496 (1966) (finding that "the simulate and historical worlds are comparable, or isomorphic[,]" in studies of decisionmaking). For a detailed discussion of simulation methodology generally and as applied to the development and testing of theories in international relations, see generally Guetzkow, supra note 915. 
development of a theory that can explain and predict ASD outcomes in causal terms as the product, in some important measure, of the personalities of decisionmakers. ${ }^{917}$

\section{Additional Dependent Variables}

Investigation of the associative relationships between personality and compliance decisions in regard to the IHL regimes governing aspects of the jus in bello, including the treatment of prisoners-ofwar ["POWs"] and the use of chemical weapons ["CWs"], will offer the prospect that the proposed theory can be validated not only as regards the resort to armed force but across a broader span of substantive issue areas that transcend the jus ad bellum. By positing explanations predictions of compliance decisions regarding the treatment of POWs and the use of CWs, the utility of the personality theory of IHL compliance to scholars and practitioners will be much enhanced.

\section{Additional Independent Variables}

The substance and process of foreign policy decisions are in effect intervening variables to which greater theoretical significance may be attributed in future iterations of this research.

\section{Quantitative Analysis}

Generation of sufficient numbers of simulated cases of ASD will allow the introduction of quantitative analytical methods, including multivariate statistics, content analysis, and pathways analysis, to complement QCA. The strengths of each method will compensate for the weaknesses of the other, enabling more detailed analysis and greater explanatory and predictive power. Quantitative analysis may permit integration of variables drawn from other levels of analysis to determine the causal significance of personality-level variables relative to inputs from the international system, the political character of states, and the nature of decisional units; such research will prove valuable in validating the causal significance of personality in IHL compliance decisionmaking.

\section{Micro-Level Theorization}

Ultimately, a more powerful theory requires the investigation and specification of the neural processes whereby personality is formed and translated into decisions. If so, future research will require not only additional analytical methodologies but the incorporation of insights from cognitive neuroscience, which in turn will require collaboration across several disciplinary boundaries. ${ }^{918}$

\section{Conclusions}

Although compliance is the most central issue in the international legal academy, at least one scholar, despairing that existing theories are ill-suited to issue-areas of high politics, has quit a corner of the field and conceded that scholarship "may have a greater impact on human well being when it focuses on areas in which international law can alter outcomes more reliably, including economic, environmental,

\footnotetext{
${ }^{917}$ Little experimental research has been conducted within the field of international law, and yet a new generation of scholars, many of whom work in subfield of compliance, recognize that progress will require the development and testing of theories of causation and that this project will in turn require natural experimentation to guide the development and testing of theories. See, e.g., Raustiala, supra note 27, at 397-98 (stating that evaluating and improving compliance with international law will require a theory of causation that can be subjected to counterfactual analysis and natural experimentation, "a rare but wonderful aid to analysis[.]"). For a detailed description of the use of simulation to test a theory of foreign policy decisionmaking, see William C. Bradford, U.S. Foreign Policy Decisionmaking in Arab-Israeli Crises: The Association of U.S. Presidential Personality Constructs with Political and Military Crisis Outcomes 234-71 (1995) (doctoral dissertation, Northwestern University, 1995).
} 
and labor issues." ${ }^{919}$ If most observers remain committed to the proposition that international law matters by virtue of its positive (and perhaps normative) influence upon state behavior, empirical patterns of inconsistency in IHL compliance may be attriting their ranks, or at least claiming from them some of the terrain upon which the debate is raging.

However, surrender, and even retreat, is at the very least premature. IHL is neither epiphenomenal to nor dispositive of the conduct of warring states. Moreover, the greatest impediment to more effective legal regulation of war is not a demonstrable pattern of noncompliance but rather the ongoing incapacity to explain and predict this pattern and offer policy-relevant guidance to the legal architects charged with making those modifications necessary to enhance compliance. Undertheorization, and not the inherent immiscibility of law and war, is the bane of IHL compliance, and it is to empirical studies of the relationships between rules and behaviors that energies must be dedicated if armed conflict is to be held within the domain of global governance.

This program need not exclude any particular school-of-thought or methodology. Although this Article assumes that human agency is crucial to the production of the phenomenon of IHL compliance and concludes that individual-level variables are therefore indispensable to explanations and predictions, the most sophisticated model will likely incorporate insights from all pre-theories and variables from multiple levels of analysis, including the nature of the foreign policy structures, the nature of the state, dyadic interactions with other states, and the international system. Just as " $[\mathrm{t}]$ here is emphatically no royal road to knowledge in the study of international relations[,]", ${ }^{920}$ there is no single method or paradigm that will enable researchers to harvest all that is knowable about IHL compliance. Each method will inform the others regardless of its own pretensions, and conflicts will generate dialectics that lead to creative synthesis. $^{921}$

Still, although the present account of the relationship is inchoate, the salience of personality to IHL compliance is an existential reality. Dimensions of personality, including militarism, anomism, hostility, and adventurism, are more effective in explaining data than are existing pre-theories, and an adequate explanation is a necessary condition precedent to systematic predictions of future compliance decisionmaking as well as to the purposive reconfiguration of the rules of IHL. Without an account of the linkages between rules and behaviors, any attempt to enhance IHL compliance by altering the existing regime will succeed only through the intervention of good fortune without which any tinkering is at least as likely to degrade compliance as it is to bolster it.

Moreover, because personality matters, the bearers of personality matter, and the collective energies and creativities of the international legal academy can no longer be devoted exclusively to the

\footnotetext{
${ }^{918}$ See Chorvat et al., supra note 895, at 3-12 (describing insights from cognitive neuroscience gleaned from sophisticated medical technologies that highlight the neural mechanisms involved in human decisionmaking regarding legal rules and establish the limits of law to alter human behavior).

${ }^{919}$ Guzman, supra note 4, at 1829.

${ }^{920}$ Michael Banks, A.J.R. Groom, \& A.N. Oppenheim, International Crisis Gaming: The Conex Experience, 1 IRRA STUD. PEACE RES. 85, 98 (1968-1969).

${ }^{921}$ See, e.g., ANTHONY CLARK AREND, LEGAL RULES AND INTERNATIONAL SOCIETY 87 (\$99) (suggesting that in an era characterized by contestation between divergent normative systems and increasing complexity it is especially important that scholars commit to interdisciplinary and intertheoretical cooperation if answers to many of the intractable problems in international relations are to be realized).
} 
production and defense of state- or systemic-level theories without knowingly sacrificing significant explanatory and predictive power. Although it is tempting for the man who has lost his keys at night in a parking lot to search for them in those areas illuminated by street lights, his best strategy for finding his keys is to search in the areas where reason and memory informs him that he is most likely to have dropped them. The analogy is apt for scholars of IHL compliance: if personality variables harness greater explanatory and predictive power than those drawn from other levels of analysis, pre-theories that underemphasize personality or relegate it to irrelevance, whether due to unfamiliarity with the literature and techniques that inform PT research or out of slavish commitments to their core assumptions, are prioritizing illumination over a successful search.

Furthermore, personality is of significance not merely from a positive perspective. Enhanced IHL compliance is a moral imperative and a crucial step in the deepening of international civil society. It is therefore essential to identify the most propitious point-of-entry into the decisionmaking process in order to facilitate the sorts of interventions that can serve this teleological mission. This Article suggests that, because much of the variation in compliance is attributable to personality, manipulation of the legal rules may well be a fruitless venture without simultaneously manipulating the personalities of HDs, either through training or through the incorporation of analysis of compliance propensities in the matrix of considerations governing their selection by domestic constituencies. ${ }^{922}$ If "history is a race between education and catastrophe, ${ }^{, 923}$ and if decisionmaking with regard to IHL compliance carries with it the possibility for the latter, our prayers and best efforts should ride with the former. Crafting the most effective IHL regime is not merely a matter of the conjuration and codification of proper rules and institutions, although these are vital steps ${ }^{924}$ : it is to the selection and training of the right people to administer, interpret, and implement the normative content animating rules and institutions to which stakeholders must also direct their attention. All those who would secure compliance with IHL must abandon the "comforting seclusion from reality that the pure theory of law once provided[.]",925

The ultimate determinants of IHL compliance lurk in the minds of the individuals who must decide whether to comply. Although competing pretheories offer complementary insights that will advance knowledge, it will be difficult to supplant personality theory as the paradigm that models the variables that most directly tap the phenomenon in question. Although the broader arenas of social

\footnotetext{
${ }^{922}$ See D'Agostino, supra note 325, at 282 (suggesting the use of training to insulate against decisional pathologies rooted in personality). Potential decisionmakers who possess personality profiles indicating they are prone to IHL noncompliance, particularly where such noncompliance may be likely to yield outcomes inconsistent with national interests, might be apprised of this information and given the opportunity, through simulation or other training, to test particular decisional strategies, internalize an accounting of associated costs, and mitigate their decisional propensities accordingly. Whether it is possible even for willing subjects to moderate personality constructs, which tend to form and become solidified in early adulthood, is perhaps a dubious proposition that requires investigation in another context, as does the suggestion that voters might require of candidates for the highest offices that they publicize their personality profiles to allow for the consideration of their expected patterns of IHL compliance as one factor in mass voting behavior.

${ }^{923}$ Attributed to H.G. WELLS.

${ }^{924}$ See Jean-Philippe Lavoyer, International Humanitarian Law and Terrorism, in Making the Voice of Humanity Heard 268 (L. Lijnzaad, J. van Sambeek, \& B. Tahzib-Lie, eds. 2004) (“[T]he main problem today [with IHL] is not a lack of rules, but the proper implementation of existing ones."); see also id. at Yves Sandoz, Prospects for Future Developments in IHL, 339, 354 ("'[I]t would be dangerously misleading to think that [problems in IHL compliance] can be solved simply by modifying the law . .. [T]he solution is not to change the law, but to find new ways of ensuring compliance[.]").

${ }^{925}$ INTERATIONAL LAW AND POLITICAL CRISIS: AN ANALYTIC CASEBOOK xiii (L. Scheinman \& D. Wilkinson 1968) (alluding to the title of the positivist tome, HANS KELSEN, THE PURE THEORY OF LAW (1934)).
} 
science and humanities are hospitable to PT, advocacy of PT is a de facto call for a major re-envisioning of the discipline of international legal compliance. During paradigmatic shifts, resistance and tension brew within the discipline undergoing transformation. ${ }^{926}$ However, the mutual object of theorists in any field should be the discovery and promulgation of new knowledge whatever its source and whatever the method that reveals it.

Armed conflict is not some disembodied and unfathomable process that holds humans captive to their own history. Rather, we are, to some important extent, authors and judges of, and therefore responsible for, our future. Wars, and the acts and omissions undertaken therein, begin "in the minds of men." ${ }^{927}$ As the field of international legal compliance unfolds in a heretofore deeply conflictual millennium, it behooves scholars to recall the insight of English literary giant Alexander Pope, who three centuries ago, while pondering the divers paths down which Enlightenment scholars were treading in pursuit of universal and infinite truths regarding the relationship of humanity to nature and to God, reminded his peers that "[t]he proper study of mankind is man." 928 The study of IHL compliance is no less than the study of mankind in a decisional crucible of his [and her] own making, and thus it is proper that our focus be brought to bear upon the relevant dimensions of the personalities of the men and women upon whom ultimate responsibility for compliance rests.

${ }^{926}$ See generally THOMAS KUHN, STRUCTURE OF SCIENTIFIC REVOLUTIONS (1961).

${ }^{927}$ See supra at*.

${ }^{928}$ Alexander Pope, Essay on Man, Epistle ii. Line 1 (1733). 